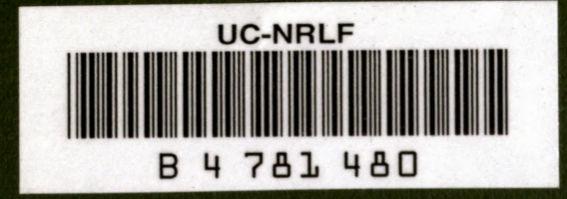


MHWAUKEE PUBLIC MUSEUM

\section{IIBRARY \\ universitr of \\ CALIRORNLA}

IIRELFROM S. A. BARRETT

\section{WTHROPOLOGY}

MILWAUKEE PUBLIC MUSEUM FROM S. A. BARRETT 
(S. A. BARRETT

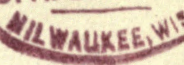

SOPERTY OA

S, A, BARRETT

Y/STARKEE WN 


SMITHSONIAN MISCELLANEOUS COLLECTIONS

VOLUME 59, NUMBER 1

\title{
THE NATIVES OF KHARGA OASIS, EGYPT
}

\author{
With Thirty-eight Plates
}

BY

DR, ALES HRDLIČKA

Curator, Division of Physical Anthropology, U. S. National Museum

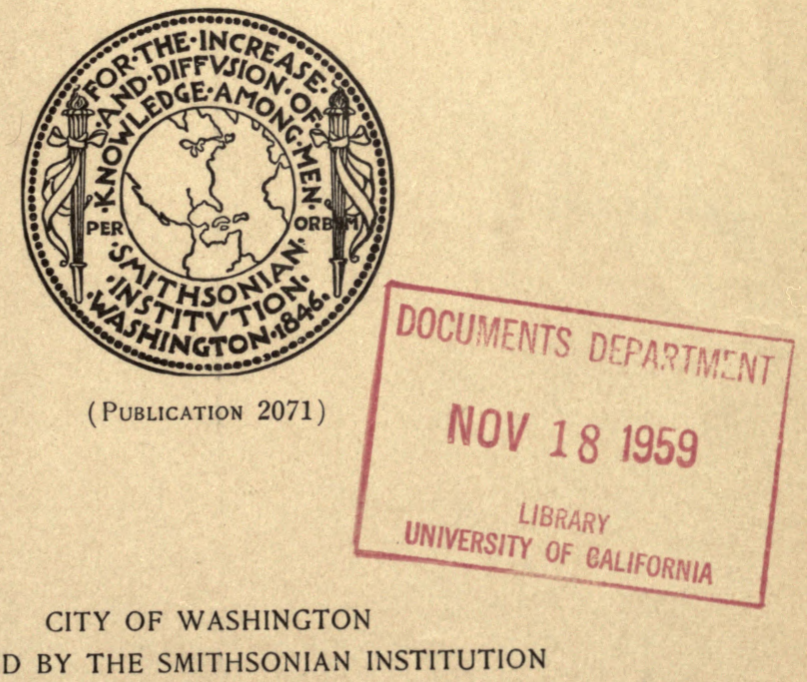


EBe Rord Obaltimore (Press

BALTIMORE, MD., U. s. A.

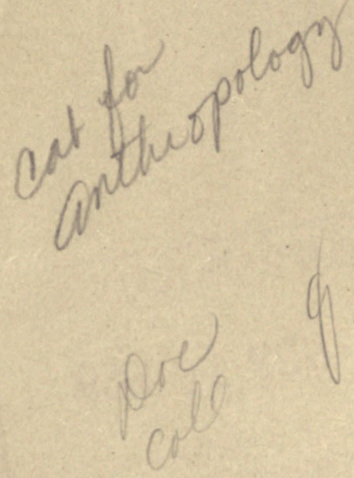


a 


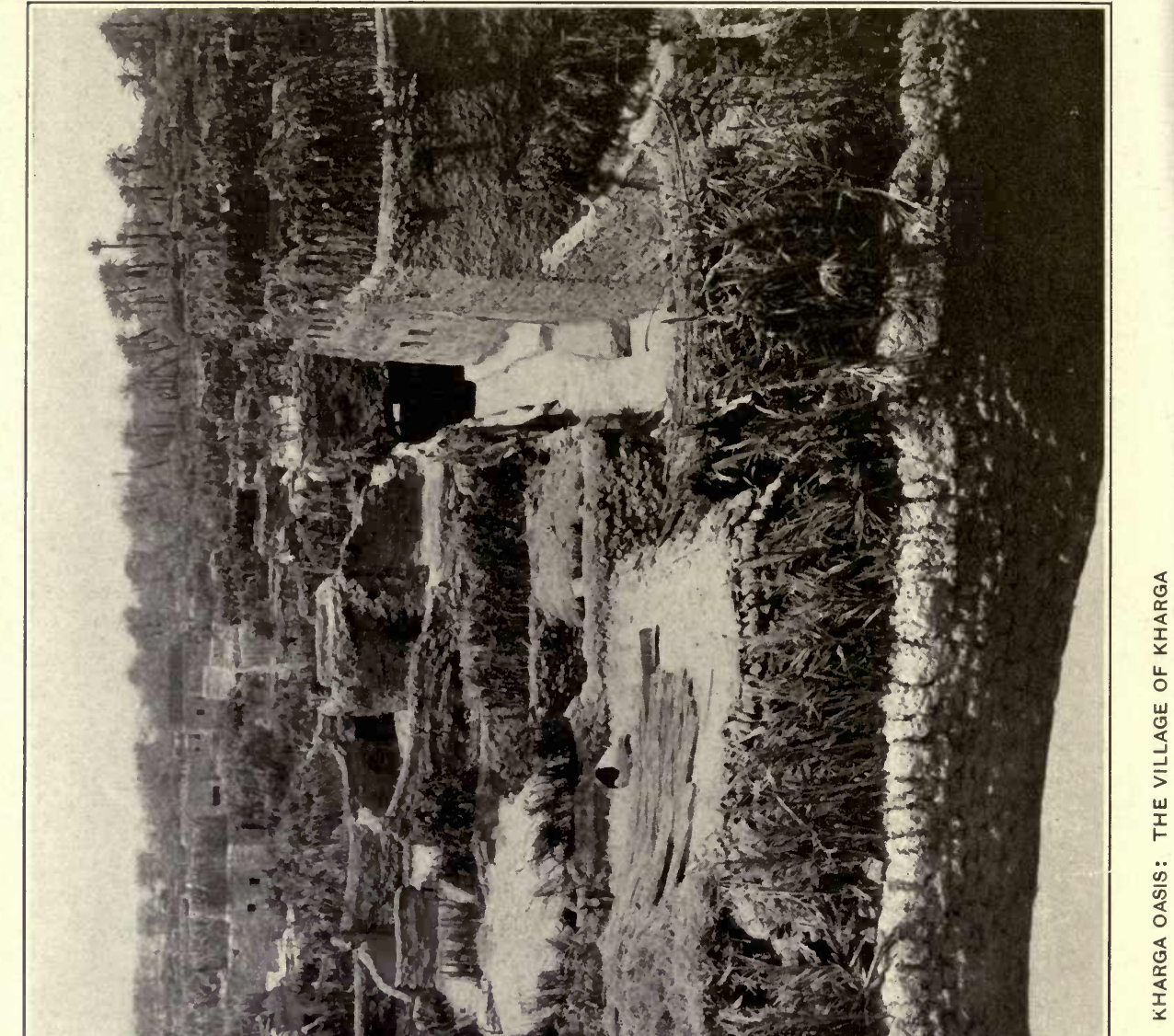




\section{CONTENTS}

Introduction

2. Geographical and historical notes on the Great Oasis ........... 3

3. Recent data on the Kharga Oasis people .................. 7

4. General observations and information gathered by the writer...... 9

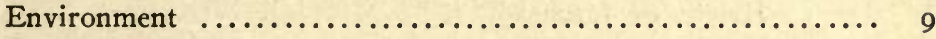

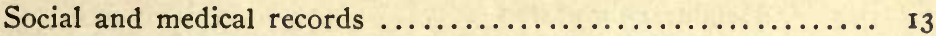

5. Vital statistics of the Kharga Oasis $\ldots \ldots \ldots \ldots \ldots \ldots \ldots \ldots \ldots$ I6

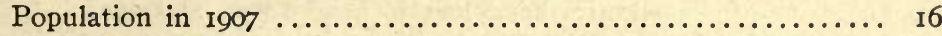

Births and Deaths ............................. I

Vital statistics of Kharga Village for five years......... I7

Vital statistics of Gennah Village for five years......... I8

Vital statistics of Boulac and Beris for one year......... I8

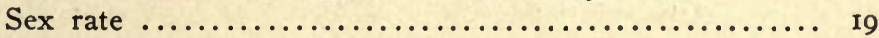

Vital statistics of Kharga and Gennah by quarters....... 20

Births and deaths at Kharga by months ............. 2I

Résumé of vital statistics ........................ 2I

6. Physiological observations on the Kharga Oasis natives $\ldots \ldots \ldots \ldots \ldots 22$

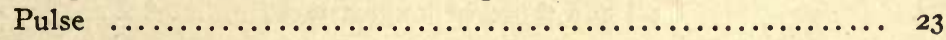

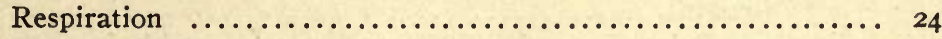

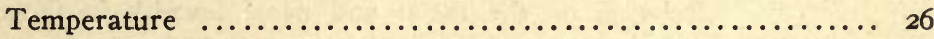

Pulse, respiration, and temperature in relation to age..... 27

Pulse, respiration, and temperature in relation to extremes of stature ............................. 28

Pulse, respiration, and temperature in relation to vigor..... 28

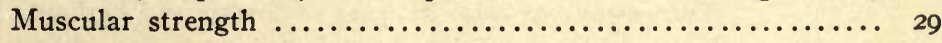

Pressure force in hands ....................... 30

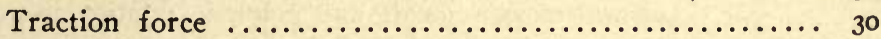

Muscular strength according to age............. 3I

Résumé of principal physiological observations ........... 32

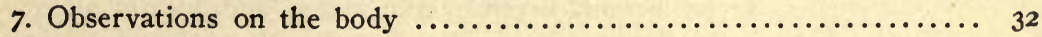

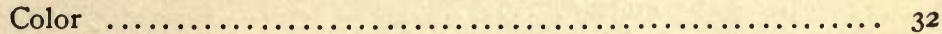

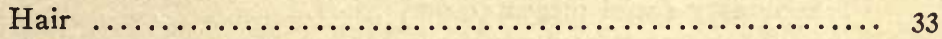

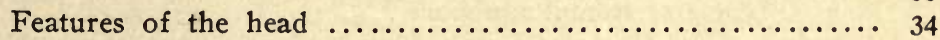

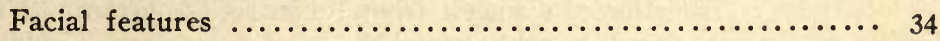

Body and limbs .......................................... 36

Concluding remarks on non-instrumental observations....... 36

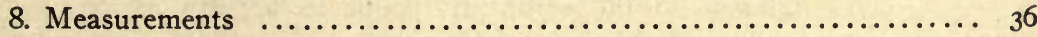

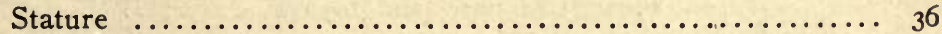

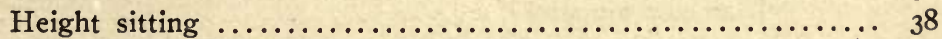

Relation of height sitting to stature $\ldots \ldots \ldots \ldots \ldots \ldots, 40$

Height and height sitting in the shortest and the tallest. $\ldots \ldots, 4^{42}$
Head $\ldots \ldots \ldots \ldots \ldots \ldots \ldots \ldots \ldots \ldots \ldots \ldots \ldots \ldots \ldots \ldots \ldots \ldots \ldots \ldots$
42

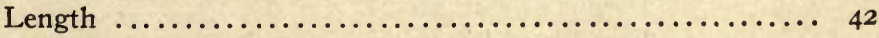

Breadth ................................ 43

Relation of length and breadth of head to stature..... 44 
Cephalic index .......................... 47

Mean cephalic index in various North-African groups.. 48

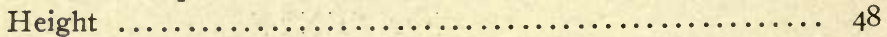

Cephalic Module ........................ 52

Relation of size of head to stature $\ldots \ldots \ldots \ldots \ldots \ldots \ldots, 54$

Relation of size of head to form of head.......... 57

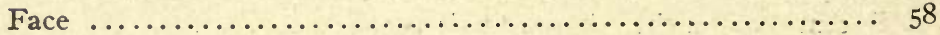

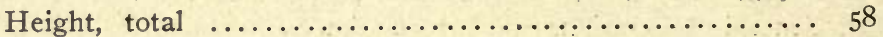

Height of forehead $\ldots \ldots \ldots \ldots \ldots \ldots \ldots \ldots \ldots \ldots \ldots \ldots$ 6o

Height, chin-nasion $\ldots \ldots \ldots \ldots \ldots \ldots \ldots \ldots \ldots \ldots \ldots \ldots \ldots \ldots$

Relation of height of face and of height of forehead to stature, head length, head form, and age....... 64

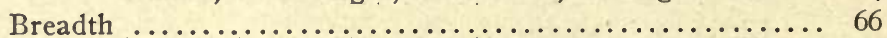

Relation of breadth of face to breadth, form, and size

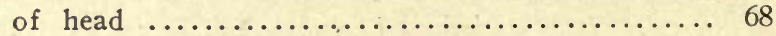

Physiognomic index $\ldots \ldots \ldots \ldots \ldots \ldots \ldots \ldots \ldots \ldots, 69 . \ldots \ldots$

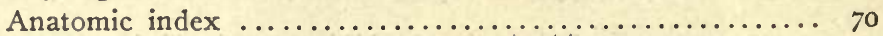

Relation of facial (anatomic) with cephalic index.... 72

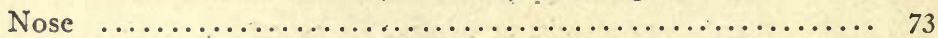

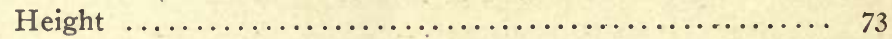

Relation of the facial and nasal height in those of shortest and those of longest faces ............. 75

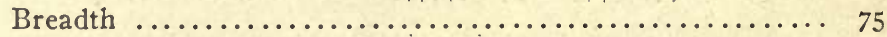

Relation of the facial and nasal breadth in those of shortest and those of longest faces ............ 76

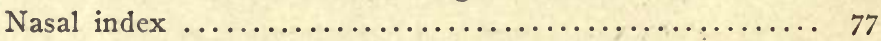

Nasal index in the living non-negroid peoples of NorthAfrica ........................... 78

Dimensions of nose in cases of lowest and highest nasal

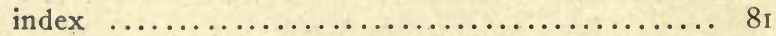

Nasal measurements and index in relation to age..... 82

Nasal index in adults between 27 and 54 years of age.. 84

Relation of nasal index to nasal height and breadth, to facial height, breadth and index, and to cephalic

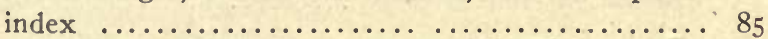

Secondary facial measurements $\ldots \ldots \ldots \ldots \ldots \ldots \ldots \ldots \ldots . \ldots 6$

Diameter frontal minimum .................... 86

Relation of diameter frontal minimum to breadth of face and breadth of head $\ldots \ldots \ldots \ldots \ldots \ldots \ldots \ldots, 87$

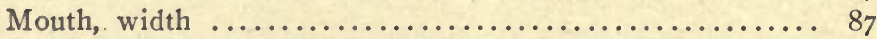

Relation of the width of mouth to breadth of face, breadth of nose, and to age............... 88

Diameter bigonial ......................... 89

Relation of diameter bigonial to breadth of face and

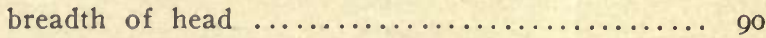

Ears ................................. 9 I

Height of left ear ..................... 92

Breadth of left ear $\ldots \ldots \ldots \ldots \ldots \ldots \ldots \ldots \ldots \ldots . \ldots . \ldots 2$

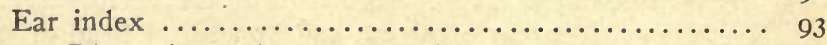

Dimensions of ears according to age.......... 94 
PAGE

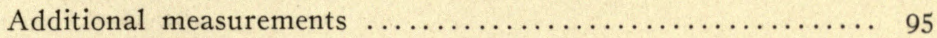

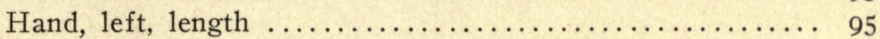

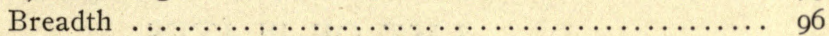

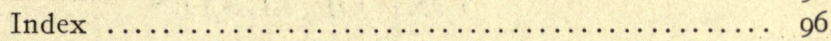

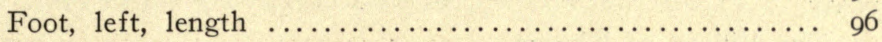

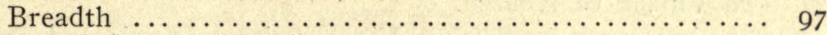

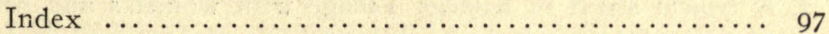

Relation of the length of the hands and feet and of their indices to stature and age $\ldots \ldots \ldots \ldots \ldots \ldots \ldots, 98$

Leg, girth .............................

Summary of the main results shown by measurements........ I00

Tables of comparison $\ldots \ldots \ldots \ldots \ldots \ldots \ldots \ldots \ldots \ldots \ldots \ldots$, 00

Comparison of measurements of the Kharga natives and various other groups of Egyptians and Nubians.... IOI

Comparison of the measurements of the Kharga men with those of Soudanese and other negroes ....... I02

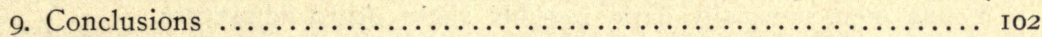

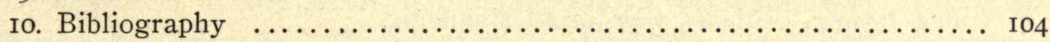

II. Appendix: Detailed measurements $\ldots \ldots \ldots \ldots \ldots \ldots \ldots \ldots \ldots \ldots$ I06 


\section{LIST OF PLATES}

PLATE

I. The Village of Kharga.

2. A typical street in Kharga Village with women's and children's quarters on roofs.

3. A street in Kharga Village.

\section{Portraits of Kharga OAsis Natives}

4. Shek Moustafa Hanádi, the Omdeh of the Oasis (his ancestors came, many generations ago, from Arabia).

5. Young man.

6. Young men; approach Nubian types in physiognomy.

7. Young men; one on right quite blind.

8. Young men, unusually dark, possibly slight negro admixture.

9. Young farmer, ordinary type of physiognomy.

Io. Two young men, showing ordinary facial features in outline.

II. Two young men.

I2. A young farmer, typical oasis physiognomy.

I3. Young farmer, somewhat asymmetric features.

14. Two men with physiognomy of Mediterranean type.

15. A man near 40 years of age.

I6. A farmer, ordinary oasis physiognomy.

I7. Man about 40, somewhat semitic type of face.

I8. Man of strong physique, ordinary Kharga physiognomy.

I9. One of the better conditioned.

20. Two farmers.

2I. Two agricultural natives, side view.

22. Man about 45 years of age.

23. Man approximately 50 years of age.

24. Two middle-aged men.

25. Middle-aged agricultural laborer.

26. Middle-aged man.

27. Middle-aged man of somewhat better class.

28. Middle-aged farmer, somewhat semitic physiognomy.

29. A farmer.

30. Man about 55 years of age.

31. A slightly ageing farmer, typical Kharga physiognomy.

32. A somewhat ageing man, fine semitic physiognomy.

33. Man near 60 years of age.

34. Ageing farmer, typical Kharga features.

35. Man about 65 years of age.

36. Somewhat aged man (loss of teeth).

37. Aged but still quite robust man.

38. Aged man. 


\title{
THE NATIVES OF THE KHARGA OASIS, EGYPT
}

\author{
BY DR. ALEŠ HRDLIČKA
}

CURATOR, DIVISION OF PHYSICAL ANTHROPOLOGY, U. S. NATIONAL MUSEUM

(With Thirty-eight Plates)

\section{INTRODUCTION}

For a number of years important and very careful archeological researches have been conducted in Egypt under the auspices of the Metropolitan Museum of Art, New York City. These researches have been carried on by Mr. A. M. Lythgoe, Curator of the Egyptian Department in the Metropolitan Museum, and his able assistants, Mr. A. C. Mace, and Mr. Herbert E. Winlock. They have extended, thus far, principally to certain pyramids and cemeteries of the XIIth Dynasty, and to the temple of Hibis as well as the large early Christian necropolis at the Great or Kharga (= Eastern) Oasis.

The dynastic monuments and cemeteries actually under exploration by the Expedition are those of Amenemhat I. and Usertesen I., the first two kings of the Middle Empire. They are situated on the western margin of the desert bordering the Nile valley, near the native town of Lisht, some thirty miles south of Cairo. The research is being directed in part toward the clearing of the great pyramid temples, and in part to the examination of what remains of the contents of the graves, particularly in the numerous and remarkable burial pits located about the more northern of the two pyramids.

The excavations have been attended from the beginning by the recovery of skeletal remains dating especially from the XIIth, but also from the XVIIIth to the XXIst Dynasties. In view of the fact that a large amount of this skeletal material could be definitely identified from a chronological standpoint, and because of the great scarcity of Egyptian skeletal remains in American collections, the writer endeavored to bring about a saving of such crania and bones for the U.S. National Museum, and eventually, due to the generosity of the authorities of the Metropolitan Museum and the aid of Mr. Lythgoe, an arrangement to that effect was perfected by the two Institutions. As a result of this arrangement, the National Museum is already in possession of more than three hundred well dated 
Egyptian crania, with a large quantity of other osseous parts; and it is hoped that as the field work goes on, this collection will increase to important proportions and form a study and reference series unique on this continent and of the highest scientific value.

The Metropolitan Museum's explorations at the Kharga Oasis resulted also in the unearthing of a considerable number of bodies, in this case proceeding from the Coptic burials of the second and third centuries A. D. This material is also destined for the U. S. National Museum. It comes mostly in the shape of natural mummies in a remarkably good state of preservation, and will be of especial value for comparisons and in the study of the entire skeletons. Some of the bones and mummies from the Oasis have already reached the National Museum, while another collection awaits transportation.

The co-operation of the two Institutions, however, soon developed the fact that for a more thorough understanding of the conditions, and also for the purpose of utilizing favorable local opportunities in the study of the living remnants of the Egyptians, particularly at the Great Oasis, a personal visit to the field by an anthropologist was desirable. Toward the end of I908, the means provided for the Metropolitan Museum expedition rendering such a visit feasible, the writer was detailed by the National Museum for the journey. He spent ten weeks in Egypt, partly at Cairo, where, due to the courtesies of Prof. G. Elliot-Smith, he was able to study the skeletal remains from several important periods, especially the invaluable early pre-dynastic, Naga-el-Der, collection; partly at the Lisht excavations, where numerous XIIth Dynasty crania and other skeletal parts were collected; and partly at the Great Oasis, where, besides some work on the mummies and skeletal remains, measurements and observations were made on 50 of the living adult male inhabitants.

The present paper deals only with the last named investigations. The value of the studies on the Kharga Oasis natives lies in the fact that these people have received as yet no scientific attention; and that, due to their isolation, and their former adherence to the Copts, they may be regarded as purer representatives of the old inhabitants of that region than the people of many parts of the valley are of their more ancient predecessors. Moreover, results of the observations ought to prove of special interest medically, due to the isolation of the people and their peculiar environmental conditions.

The studies were restricted to individuals of normal (that is, nonpathological) development, who did not show by their hair or fea- 
tures negro admixture. The selection on the last mentioned basis is of particular importance, for an inclusion of those who are visibly part negro would necessarily vitiate the outcome of the observations. Even with the precaution taken some individuals were doubtless included who were not free from negro blood, but the influence of such unrecognizable cases on the results must be small. The mixture with the negro at the Oasis is on the whole less extensive than in some parts of the valley. It is also in general more modern and more easily eliminated.

The women of the Oasis, regrettably, could not be studied, due to the restrictions of the Mohammedan religion.

\section{GEOGRAPHICAL AND HISTORICAL NOTES ON THE GREAT OASIS}

The Kharga Oasis lies ${ }^{1}$ I 30 miles west from Luxor, the ancient Thebes; the nearest point on the Nile, however, is less distant. For the last four years it has been connected with the Nile valley by a railroad; before that time it was reached only by from three to five days' journey across the desert with camels.

The Oasis is a great but shallow and flat depression, over 3,000 square kilometers in extent, in the Libyan Desert, which in these regions is absolutely barren. It extends roughly between the parallels of $26^{\circ}$ to $24^{\circ}$ north latitude and forms the eastern portion of an immense shallow natural excavation, the western part of which is the Western or Dakhla Oasis (fig. I).

The Kharga Oasis has been peopled since early dynastic if not pre-dynastic times. It yields ancient stone implements, is mentioned in some of the oldest Egyptian records, and contains the remains of numerous old settlements as well as of several temples. It also has the best preserved Coptic necropolis.

At the present time, as probably always in the past, a great part of the Oasis depression is desert. The habitable portions are those that contain flowing, generally artificial wells. These parts, several in number, are separated by the sands and barrens and are the real oases in the great arid desert depression.

Each of these smaller or larger watered areas is represented by a village or town, the main of which, from north to south, are known as Kharga, Gennah, Boulac or Bulaq, and Beris. In addition there

${ }^{1}$ Following, in the main, J. Ball, "Kharga Oasis: its Topography and Geology." Geological Survey Report. Survey Department, Egypt, I899; ${ }^{\circ}$. Cairo, I900; and Beadnell, H. J. L.-An Egyptian Oasis, $8^{\circ}$, London, I909. 
are several settlements of minor importance, and a number of places that are occupied only for a time each year, during the growing or gathering of crops.

The total number of the present inhabitants of the Great Oasis, including some Bedouins, is somewhat less that 10,000. Their

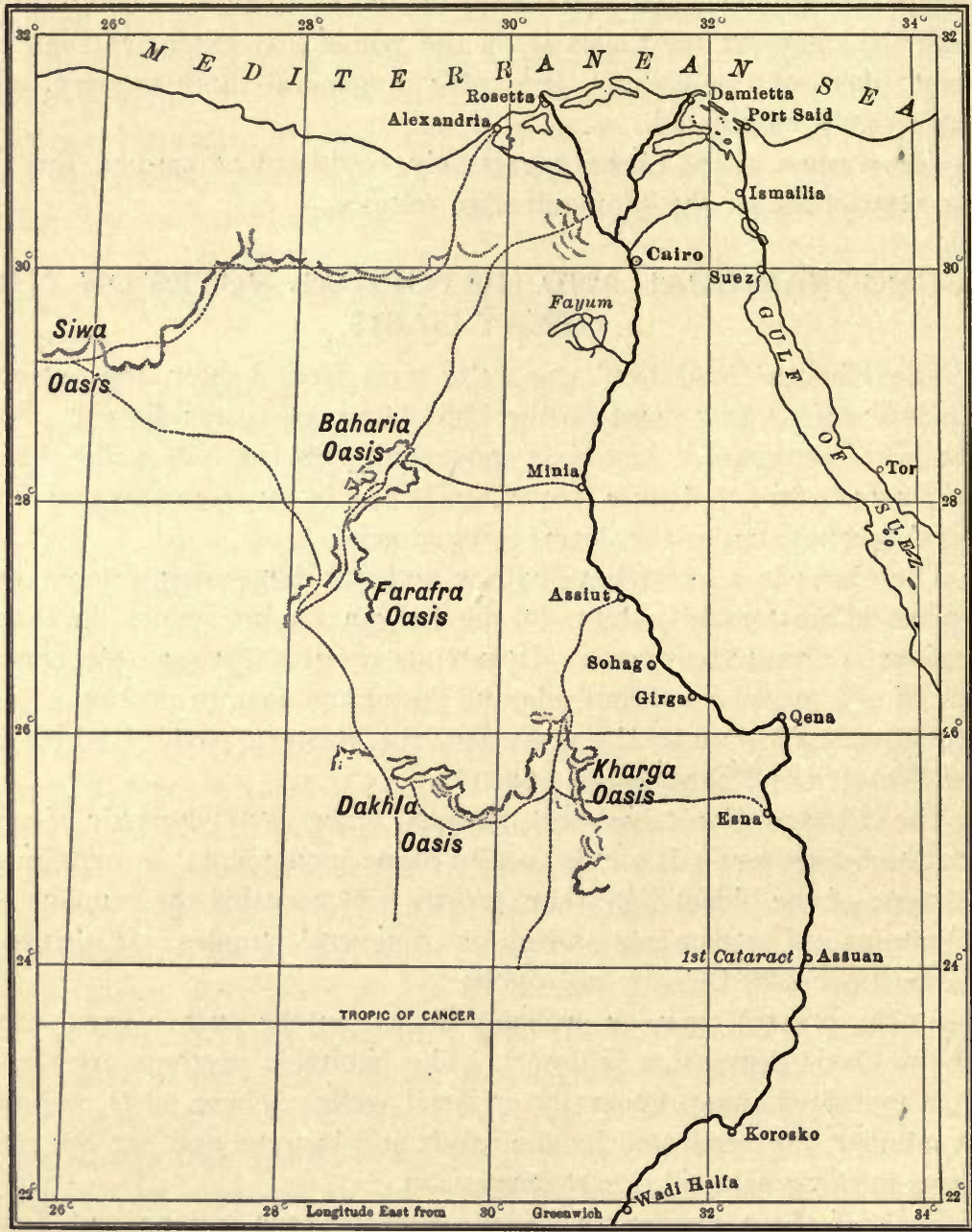

FIG. I.-Sketch map of Egypt, showing the position of the oases. (After Ball.)

ethnic origin and the time of their immigration into the Oasis are both uncertain. The earliest record thus far discovered relating directly to the Oasis dates from the XIIth Dynasty, or a little less 
than 2000 years B. C. It narrates that "Ikudidi, a steward of Sesostris I., was dispatched by him to the great oasis of El Khargeh on the west of Abydos, whence the caravans started thither "; which would seem to indicate that the Oasis already formed a component part of upper Egypt and was in frequent communication with that country.

There is in existence, however, a much earlier and very suggestive record, which possibly implies a still more ancient suzerainty of Egypt over the southwestern settlement, and may contain a clew to the ethnic derivation of the early inhabitants of the Oasis. It dates from the reign of Mernere, of the 6th Dynasty, or from about 2500 years B. C., and speaks of a general of that king dispatched to the " distant Yam," which is identified by Egyptologists as a part of Nubia lying between the second and third cataracts." Arriving in Yam, Harkhuf, the general in question, "found its chief engaged in a war with the southernmost settlements of the Temehu tribes, related to the Libyans, on the west of Yam. Harkhuf immediately went after him and had no difficulty in reducing him to subjection." s

If the tribes west of the Yam people were of the Temehu, related to the Libyans or Berbers, then it is quite probable that the Kharga Oasis people, dwelling approximately 300 miles more northward of the Yam country, in the Libyan desert and in the line of migration from the Libyan lands in the north, were of the same extraction. It is even possible that the mention referred directly to the southern Oasis (Kharga and Dakhla), in which case the record would also imply that the Oasis inhabitants were at that time subjects of Egypt and as such received protection.

As to references in foreign authors, Herodotus writes (Thalia) that the Persian troops of Cambyses "who were sent against the Ammonians, leaving Thebes, followed their guides, and appear to have reached the city Oasis, which those Samians, who are said to be of the Aeschrionian tribe, inhabit, distant from Thebes seven days' journey across the sand." This can, its seems, refer only to the Great Oasis ; but it is not clear who were meant by the Aeschrionians.

Edmonstone " mentions a passage from Josephus contra Apionem,

\footnotetext{
${ }^{1}$ Breasted, J. H. : Ancient Records of Egypt, Vol. I, Chicago, 1905, pp. 524528; A History of Egypt, 2 d ed., $8^{\circ}$ N. Y., I909, p. I82.

${ }^{2}$ See map at the end of the volume in Breasted's History of Egypt, cited in the preceding foot-note.

${ }^{3}$ Breasted, J. H.: Ancient Records of Egypt, Vol. I, pp. 333-336; History of Egypt, 1909, p. I38.

1 Edmonstone, A.: A Journey to Two of the Oases of Upper Egypt. $8^{\circ}$. London, 1822, pp. I33-I34.
} 
Lib. 2, which indicates that in the time of Josephus the population of those remote tracts was considered as pure Egyptian. In attacking Apion, Josephus accuses him of wishing to be considered a Greek, when he is an Egyptian, and says "He believes himself [a Greek], and that too, being born in the Oasis of Egypt whence he is, as one would say, the first of all Egyptians."

During the periods of the Persian, Greek, and Roman dominions of Egypt, the Oasis was evidently regarded as an inherent part of Egypt and its inhabitants as not differing from the Valley Egyptians. It suffered, as it probably did before, invasions of the more southern and more warlike tribes, which, however, did not result in colonization.

Edmonstone thus quotes (pp. I39-I40) ${ }^{1}$ two letters of the bishop Nestorius, referring to later times, particularly to destructive raids on the Oasis by the "Blemmyes" and other more southern tribes: "After the Oasis was, as I mentioned above, taken by the barbarian (Blemmyes), and completely laid waste and devastated by fire, they who, for what cause I know not, carried me off, suddenly took compassion and dismissed me, adding threats, however, if I did not instantly leave the country, for they said the Maziei were to take possession as soon as we left it." The Blemmyes, according to Strabo (Xylandri, L. 17, p. 786), were subject to the Ethiopians, and inhabited "both sides of the Nile, on the borders of Egypt, to which country, being a nomad race, they became very troublesome neighbors." These raids have in all probability repeatedly reduced the population of the Oasis, but did not alter its ethnic nature.

There are a few later records concerning Kharga, touching on its famous wines, on its tributes to Egypt, on its being used as a place of banishment (particularly during the early centuries of the Christian era) and on its temples, its Christians (Copts), and its garrisons, ${ }^{2}$ but these contain nothing of anthropological interest except the indication of the affluence to the Oasis, through those who were banished thither and through the garrison personnel, of foreign

${ }^{1}$ From Evagrius, Hist. Ecl., Lil. I, cap. 5.

'The references apply in some of the cases to the oases in general. Thus, for instance, the "Notitia dignitatum," composed under the sons of Theodosius the Great and mentioned by Schweinfurth in his "Notizen zur Kenntniss der Oase El-Chargeh" (Petermann's Mittheilungen, 1875 , p. 385), speaks of the garrisons of the oases as having been composed of Quades, Armenians and Ahasges. And when the Great Oasis is spoken of separately it doubtless includes mostly Dakhla as well as Kharga, for these were not always distinguished as two separate territories. 
racial elements, some of which doubtless mixed or fused with the population ; but the total effect of these mixtures on the physical status of the Oasis people was probably only moderate. The inscriptions on the temple of Hibis, at Kharga, refer to the oases, according to Beadnell, under the comprehensive name "Set-ament," or " the Western Lands," without any further distinction or information.

The above is about all that can be said about the Oasis from the anthropological standpoint up to the time of the Arab invasion concerning which there are no details. After the coming of the Arabs, however, and the introduction of the camel, there followed the establishment, or more probably an increase in importance, of the SoudanAssiout and other caravan routes, which lead across the Oasis. The Soudan route then became the artery of extensive black slave traffic and this introduced gradually into the Oasis a supply of Soudanese negro slaves, and influenced to an important degree the racial character of the natives. The slaves were obtained from the caravans in exchange for animals or goods, or as leavings in cases of sickness or accident, and were eventually embodied into the population. In the course of several hundred years, this negro admixture accumulated to such a degree that today nearly one-third of the inhabitants of the Oasis show more or less pronounced traces of negro admixture.

Some of the negro admixture is recent, or well remembered in the families, other admixture is older and more difficult to trace; but very nearly all is post-Coptic, for the mummies and bones recovered from the great Coptic necropolis present almost exclusively hair and features of a non-negroid character.

There doubtless also came into the Oasis in the course of time some settlers from the Nile valley. How strong the Arab and the Valley accessions may have been, particularly in periods of partial depopulation of the Oasis by epidemics or enemies, it is impossible to say, yet it is probable that not many were attracted to the isolated, exposed, initially quite unhealthful, and especially poor region, and that the bulk of the population maintained or renewed itself principally through natural augmentation.

\section{RECENT DATA ON THE KHARGA OASIS PEOPLE}

Modern references to the Egyptians of the Great Oasis are almost as scarce as those of the older times, and what there are, with one or two exceptions, touch only indirectly on the people themselves. The

\footnotetext{
${ }^{1}$ During the writer's examination a man was found whose family claims descent from a Roman soldier married to a native woman; and there are said to be several such cases in the Oasis.
} 
literature is given in the bibliography. A few data of especial interest are as follows:

Browne, who passed through the Oasis in $1793,{ }^{1}$ mentions the acquiring by the inhabitants of Nubian negro slaves (p. 26I): "When we came to Beiris we were met by a Cashef, who welcomed the Ielabs with an exhibition of fireworks; on this occasion he treats the chief merchants with coffee, and presents to each a benish of coarse cloth, worth about a guinea, expecting, however, in return a slave from each, worth at least ten guineas."

Quatremère, ${ }^{2}$ in I8II, mentions a new devastation of the Great Oasis by the Blemmyes.

In 1835, the Kharga Oasis was visited by Hoskins, and in the description of his journey, published in $18377^{3}$ the author says (p. $8 \mathrm{I}$ ): "The inhabitants of this town (Khargeh), and indeed of all the Oasis, have (with some exceptions), not such strongly marked features as the Arab of the Nile, and their complexion is lighter than that of the peasants of Egypt in the same latitude. But they are chiefly remarkable for the pallid and unhealthly hue of their countenances, just such a tint, or rather expression, allowing for the difference of color, as distinguishes the inhabitants of the Pontine marshes; a languid and sickly appearance; a listlessness in their manner; a sluggishness in their movements; a total want of energy and vivacity-all proofs of the insalubrity of the climate, and the wretched effects of a baneful malaria. This pallid hue is most remarkable in their children and women; the men, exposed to the influence of a tropical sun, have an appearance somewhat less unhealthy." On pp. 82-83 Hoskins mentions the presence at the Oasis of malaria and ophthalmia; on pp. 86-88 he says "the women are not obliged to cover their faces or live in the seclusion of harem "- conditions now quite changed. The women, he thinks (p. 87), with their "pale complexion" are better looking than those of the Valley and have more regular features. Finally, on page 89 , he estimates the population of the whole Oasis at 4,300, of Kharga alone at 3,000.

Caillaud, Schweinfurth, Brugsch, Golenischeff, and Ball give valuable data on the archeology of the Kharga Oasis, and the last

\footnotetext{
${ }^{1}$ Browne, W. G.: Travels in Africa, Egypt and Syria. $4^{\circ}$. 2 d ed., London, I806.

${ }^{2}$ Quatremère, E. : Mémoires géographiques et historiques sur l'Egypt, etc., 2 Vols., $8^{\circ}$, Paris, I8ri.

${ }^{8}$ Hoskins, G. A.: Visit to the Great Oasis of the Libyan Desert. $8^{\circ}$, London, 1837.
} 
named, as well as Beadnell, quotes the Egyptian census statistics as to its population respectively in 1897 and 1907 .

Brugsch, Sayce, and Beadnell also give historical data concerning the Oasis. The original inhabitants are regarded as of Libyan (Berber) origin. Beadnell's work, ${ }^{1}$ as also that of Ball, contains much interesting data concerning the Kharga wells and underground water tunnels, but no special observations are recorded on the inhabitants of the Oasis. The few references accorded them in this and other publications represent them as rather a backward, mild, and somewhat impotent people.

The physical anthropology of the Kharga people, especially, is as yet a virgin ground. But there is also a dearth of scientific information on the living Egyptians of the valley, though valuable series of observations on the latter have been published by Chantre and more recently by Myers of Cambridge.

\section{GENERAL OBSERVATIONS, AND INFORMATION GATHERED BY THE WRITER}

\section{ENVIRONMENT}

The shallow depression of the Kharga Oasis is an uneven, barren, predominantly sandy waste, partly surrounded or cut into by equally barren rocky scarps or hills. It is covered over a great area with moving sand-dunes, and spotted with smaller or larger patches of green within the waste: the watered ground and native settlements. Some of these patches are near enough each other to be within sight, but others are separated by large areas of the desert, forming really separate oases.

The largest of these inhabited and cultivated portions is that of the principal village or town, named also Kharga, and it was in this village and the neighborhood that the writer made his observations.

The life in the Oasis depends entirely on the water obtained from artesian wells, which are of native and to a large extent of ancient make, and which tap deep supplies in the Nubian sandstone that forms the floor of the whole depression. The water thus obtained makes possible the existence of a few moderate groves of date palm and of some gardens with olive as well as orange trees, and it serves for the irrigation of a limited extent of ground used for agricul-

${ }^{1}$ Beadnell, H. J. L.: An Egyptian Oasis, 8, London, 1909, pp. 66-67. 
ture. ${ }^{1}$ On the irrigated fields the natives raise a variety of barley, rice, and some wheat, with a little sorghum and a few vegetables. The land is generally poor and, as at Ball's visit, over a decade ago, what is raised, excepting the dates, barely suffices for the home consumption. A quantity of the dates is exported to the Valley.

The climate is that of the Libyan desert in general, subtropical, except that the air, due to local evaporation, is less dry. Rain is very rare. The predominating winds are from the north, although during a part of the summer season sultry winds blow from the south. Sand storms are frequent at certain times of the year and are very troublesome.

The wells in the condition in which they are kept are by no means an unmitigated blessing. They are all open and many form pools, overflows, and marshy spots, which are instrumental in the generation of great numbers of mosquitoes of several varieties, including that which disseminates malaria.

The Oasis is also infested, especially in the spring and the summer months, with great numbers of small and ordinary-sized flies, which possess the annoying and dangerous instinct of trying to feed on the moisture or discharges of the eyes, nose, and mouth. They are the transmitters of trachoma and doubtless of other pathological conditions. Curiously they are decidedly more numerous and troublesome outside than inside the villages. In April of each year there appears at the watered places, in addition to the common varieties, a larger fly, which bites camels, inoculating them with a disease that often has a fatal result. Occasionally this fly also bites men, but in this case the bite is not dangerous. The Oasis harbors also several poisonous reptiles."

The Oasis natives live, as mentioned above, principally in four villages (Kharga, Gennah, Boulac, and Beris), though there are six other smaller settlements. These villages are of considerable interest from the standpoint of primitive architecture. By far the largest and most populous is Kharga, which is inhabited by about one-half of the total population of the Oasis, and deserves a brief special description (plates I-3).

\footnotetext{
${ }^{1}$ The number of taxable palm trees in 1897 , according to Ball (1. c. p. 46), was rather less than eight to each head of population, while the total taxed water supply per person amounted to about 15 cubic meters per day. These conditions have changed but little, if any, since then. The cultivated area of land was, in 1907 , less than 19 square kilometers, or a little over half an acre to a person, out of the total oasis area of considerably over 3,000 square kilometers.

${ }^{2}$ Further details are given under notes on pathology.
} 


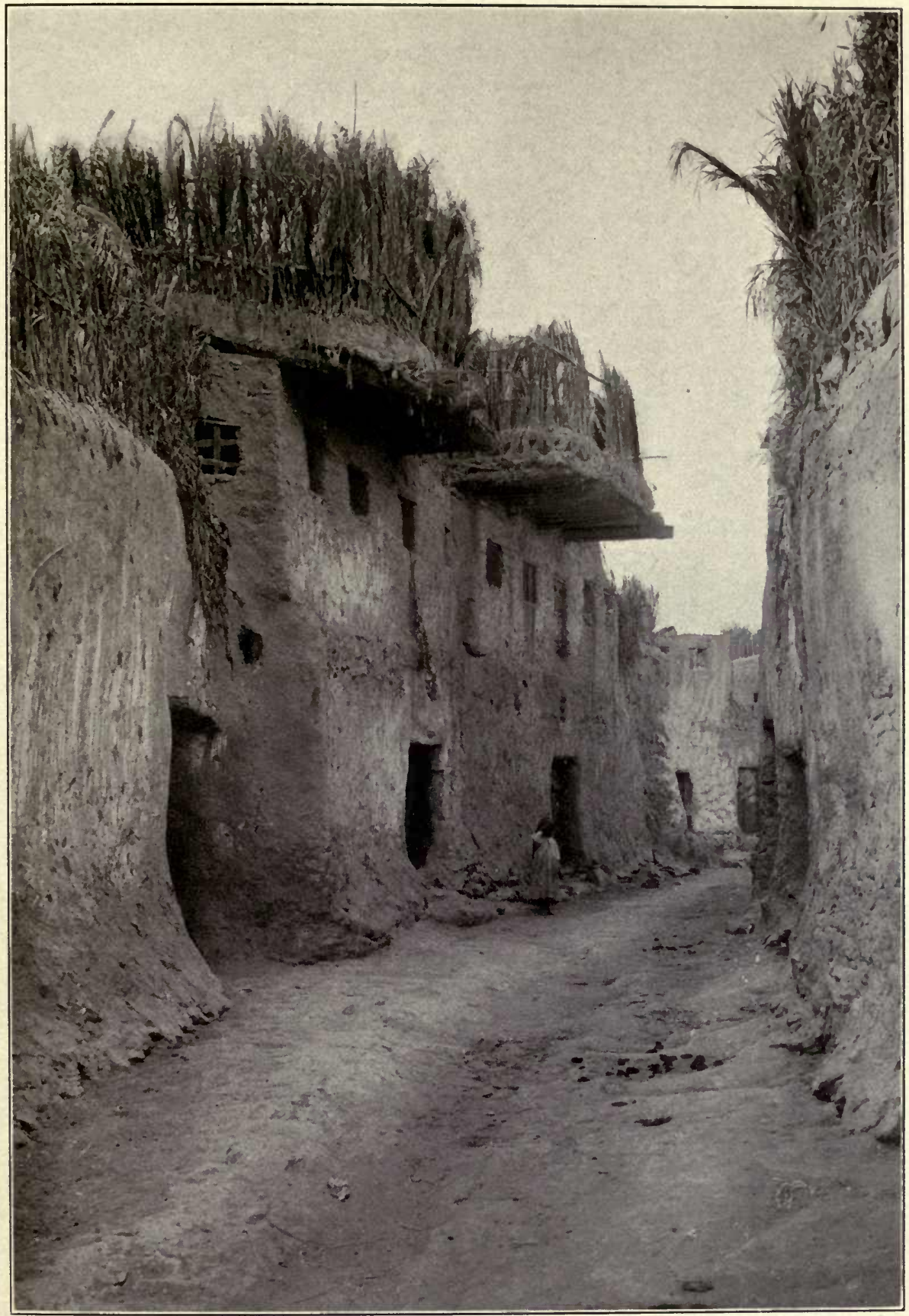

KHARGA OASIS: A TYPICAL STREET IN KHARGA VILLAGE WITH WOMEN'S AND CHILDREN'S QUARTERS ON ROOFS 


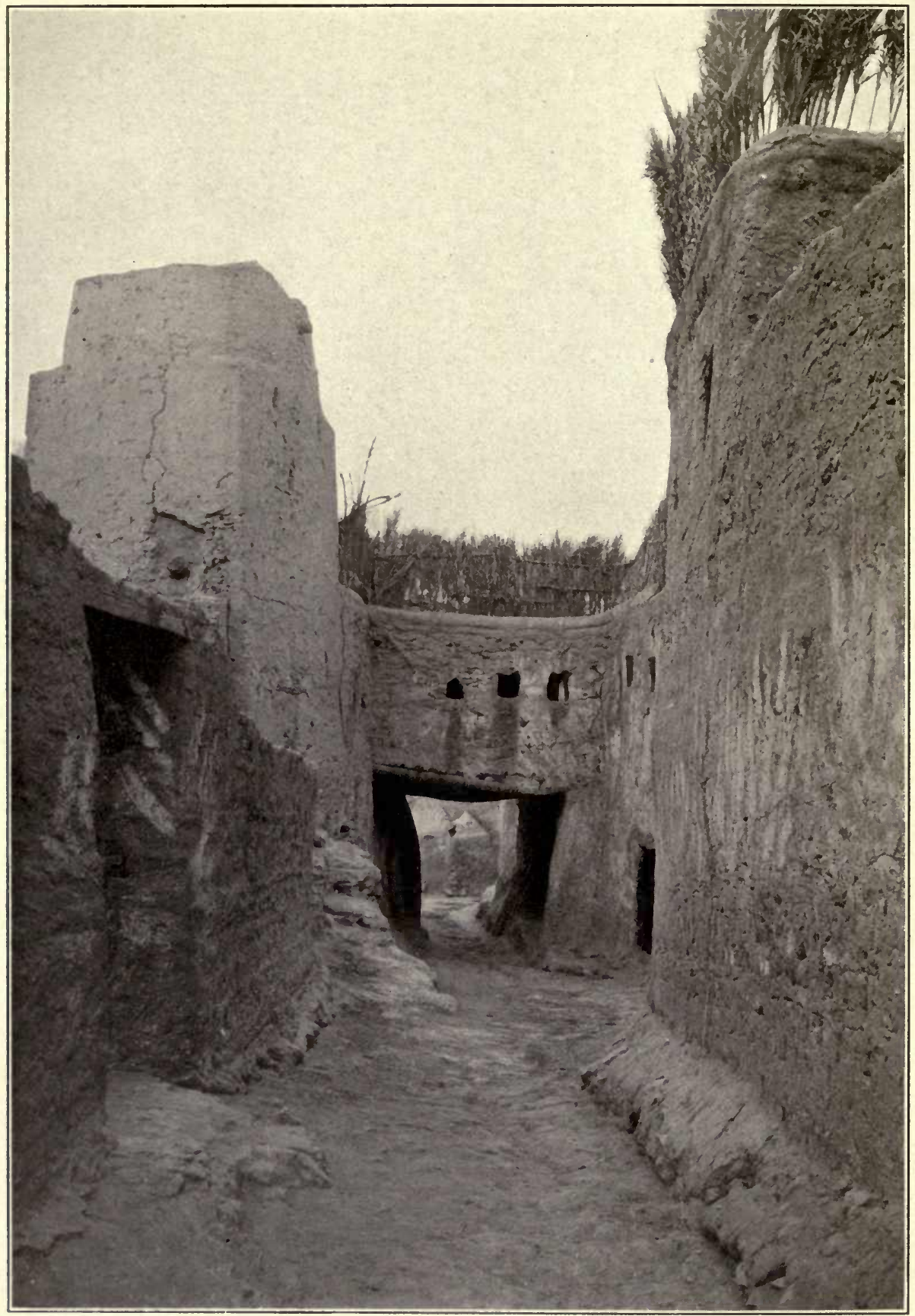

KHARGA OASIS: A STREET IN KHARGA VILLAGE 
Kharga may be called a great Egyptian village, modified in a peculiar manner by local requirements. It is constructed with special regard to protection from the sun, heat, and winds, and also for easier defense against invaders, an important precaution in the past. It is built of mud and sun-dried bricks; the posts of the dwellings are of palmwood, the ceilings of palm leaf ribs and mud.

The main part of the village is a maze of narrow, sinuous, intricate streets. Futhermore, in the case of most of the narrower passages the upper stories of the houses have been built completely across to the opposite side, converting the street into a tortuous, very dark, tunnel or gallery, five to seven feet high, which is always cool, quiet and free from blowing sand, and in which defense would be easy. A visitor can not find his way through these passages without a guide.

The houses are one to two stories high, in style like those of the poorer classes in the Valley. They are mostly small, irregular and piled together, as everywhere in Egypt. In many instances there is an open air living room on the top of the dwelling, fenced in by a hedge of dry palm leaves or ribs; this room is made use of mainly by the women and children (plate 2 ).

The dwellings as well as the streets are now kept, due to government regulations, in a neat condition, but formerly are said to have been filthy. There is, of course, no system of sewers and the disposal of sewage is primitive. Water is carried to the dwellings principally from a small open reservoir located within the town and fed by a surging well. It is distributed in goat-skins, and curiously, by blind men who, notwithstanding their defect, are said to be masters of all the intricacies of the streets and tunnel-like passages.

The apartments, so far as seen, are of very moderate dimensions and often lacking in light. There are also only poor provisions for the escape of smoke; but the inside rooms are quite fireproof and afford good protection against heat as well as cold, and against the winds and sands.

The people are in general poor. In occupation, the large majority are agriculturists, and they gain only enough for the bare necessities. They dress cheaply and lightly, in the main much like the fellaheen (agricultural workers) of the Nile Valley. The ordinary external robe or garment does not differ much in the two sexes; vests and inner garments, however (where worn), and also the outer garments of better quality, as well as decorations, are distinctive. Some of the women wear a metal ring which pierces one 
of the alæ of the nose and hangs down to the lips. The head in men, closely cropped or even partly shaved, is covered with a closely fitting cap, or is lightly turbaned, that of the women at home bare, in public covered with an outer garment. The neck as a rule is uncovered. A large majority of individuals of both sexes go barefooted, except on special occasions.

The family life appears to be the same as that of the poor Egyptian of the Valley. Except the few who are better to do, the people sleep on the floor, on thin palm-strip mats, and, according to the village authorities, often without covers; not because they do not need the latter (though the rooms are probably never very cold), but because they have none.

The meals are generally only two a day, morning and evening; and among the majority of the population there is but little variety in the food. The predominant and often exclusive articles of diet are rice, in rice time; barley, in barley time; and dates, in date time. There is scarcely any milk and no butter. There are small tough chickens and their small eggs, but these go in a large part to the better conditioned and now in a measure also to the Valley. Meat among the ordinary people is not eaten more than perhaps, on the average, once a month, and then it is usually not of the best quality. They eat cats and probably dogs, though the latter are scarce, there being now only about a score in the whole village. The Kharga natives used to eat household animals of all kinds. They even ate camels that were diseased, butchering them just before they died, but this practice is now prohibited by the government.

Domestic animals consist of donkeys, a few cows, goats, and sheep. Donkeys are the most common. All these animals are diminutive in size and often poorly nourished. The few families who are better off financially own one or more camels, which alone of the domesticated Oasis animals are usually in a fairly good condition.

The occupation of the natives, as already mentioned, is almost exclusively agricultural work. ${ }^{1}$ Industry and manufactures are lim-

\footnotetext{
${ }^{1}$ In census of 1907 , the occupations of the Kharga people are given as follows :

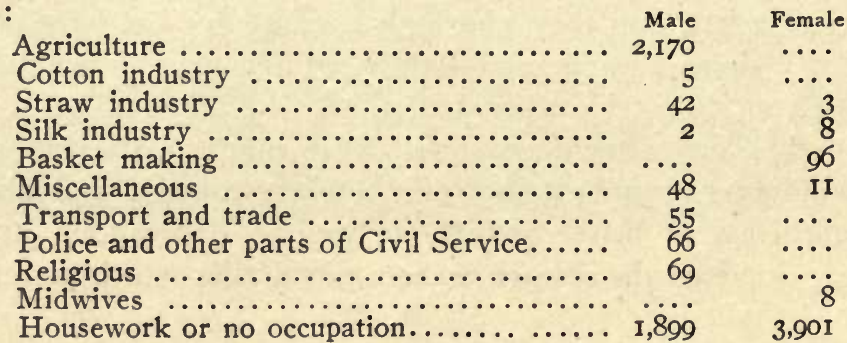


ited, the latter consisting of the production of mats, baskets, a variety of cloth, and some pottery. Of trade there is but little, and buying and selling has been and is still mostly by barter. Yet there are now several stores in which simple necessities can be purchased for money, and regular trade with the Valley is increasing.

The Kharga Oasis natives are not great workers, which, as will be seen further on, has its physiological and medical reasons.

\section{SOCIAL AND MEDICAL RECORDS}

As to social and medical matters, a few details were learned from the Omdeh (local head official), the Maowen (government head official) and the government physician. According to this information, there is in the Oasis scarcely any serious crime. The people do not like to fight and do not kill. They do not beat women or children. When anything is stolen, which is infrequent, a flag is put up as a sign that the property has been placed in the protection of a "sheikh," a dead holy man, in or near the place where the object was stolen, and this will often lead the thief to return the property.

As to family life, girls are married from nine years onward. They commence to menstruate mostly at from eleven to thirteen, and generally bear children soon after.

Marriage is not greatly binding. Among the poor they often marry when there are plenty of dates or other food; when the food supply has run low or been exhausted and the man can no longer support his wife, they separate. Next year, the parties may re-unite or marry others. Plurality of wives is said to be rare, they can not be provided for.

The number of children born is large (see Statistics), but there is also a high infant mortality. From the medical standpoint, the people, while not robust, can not be said to be very sickly. Only little, however, could be learned in this respect about the women, who are forbidden to associate, with or even show their face to strangers. ${ }^{1}$ The government doctor is not called to confinements. ${ }^{2}$ $\mathrm{He}$ is not called to treat women at all. They are left when ill to nature, and their own devices.

There are no native "doctors" and there is but little folk-medicine. Written passages from the Koran often take the place of medicines. Curiously enough, there are traces or remnants of some medical

${ }^{1}$ The only opportunity the writer had of seeing the women with faces uncovered and in a larger number was during funerals which they are in the habit of attending, in fact, conducting.

${ }^{2}$ There are several native midwives. 
usages of European origin, which must have been brought to the country by the Arabs. One of these is a vaccination which the natives, particularly the Bedouins, perform one on the other. It is a direct vaccination, some of the pus from the sores of a subject attacked with smallpox being introduced into an abrasion produced by a razor in the skin of the one to be protected. The wound is made preferably on the leg.

The most interesting condition is the apparent absence among these poor and mostly under-nourished people of tuberculosis, which recalls a similar condition among the poor Jews. No case of any variety, including scrofula, was seen at the Oasis by the writer, and none was seen by the government physician during his twelve months' stay at the village of Kharga or in other places in the Oasis. The physician declared, however, that he found tuberculosis of the lungs in several cases in camels.

Neither the doctor nor the civil authorities of the Kharga village could recall a single case of well marked rachitis, and no instance of the condition was encountered.

There have been no epidemics recently in the Oasis, with the exception of measles, in 1908.

Children die principally from gastro-enteritis, broncho-pneumonia, and of measles. The epidemic of the latter disease in 1908 carried off many infants.

There were seen no evidences of syphilis or gonorrhœa, but the diseases are said to exist as they do in the Valley.

Malaria is not very frequent, except in the date season (September-October), when there are also extraordinary numbers of flies and mosquitoes. It is occasionally of a very dangerous form. Typhoid is rare.

A most prevalent disorder is trachoma. There are great numbers of blind, and in many more the eyes are more or less affected by various forms of inflammation.

A frequent condition, due probably in most if not all cases to trachoma is trichiasis (contraction due to inflammatory changes of the ventral surface of the lids, and consequent direction of the eyelashes inward, so that they irritate the cornea). This condition is usually observed in the upper lid.

\footnotetext{
${ }^{1}$ According to the returns of the 1907 Egyptian census there were at the Kharga Oasis 196 blind in both eyes and 432 blind in one eye, or nearly 75 per thousand of the total population blind in one or both eyes. In the United States the percentage of those partly and completely blind is less than one per thousand of the population (in I900, U. S. Census, 0.85 per thousand).
} 
Insanity, the authorities of the village declared, is very rare; within the last decade they knew in the village of Kharga of but one case, and that in a negro. ${ }^{1}$ Imbecility and also epilepsy of lower grades, exist, but no definite data could be obtained as to their frequency. No one knew of any instance of advanced idiocy.

The presence of albinism is not certain. Two cases were reported of brown children with blue eyes, but they were not seen. Leukoderma or patch-albinism was found in a man of about 55 with semitic features. Very premature greyness, of probably different etiology from the preceding, was seen in one man about 30 years of age; it was limited to the scalp.

Leprosy occurs, but the cases are isolated and rare.

Fractures of bones and dislocations are very infrequent.

Scorpion bites occur each year. They are said to be occasionally fatal in children and sometimes also in adults, when the sting penetrates a blood vessel. There are two varieties of scorpion-a small yellow one which is found about the houses and a larger greenish one in the desert and hills.

There are in the Oasis at least two and possibly three varieties of poisonous snakes, including the ordinary sand viper, the horned viper, and possibly also a cobra. The last named, if it exists at all, is very rare. Several viper bites happen every year. Within the last twelve months the physician in the Kharga village treated three such, all in adult men. One of the bites was in the hand and the patient died in three days; the other two men recovered. The treatment in the fatal case consisted of incision, injection of permanganate of potash and bandaging. In the other two (one being in a hand and one in a foot) it consisted of incisions with bandages and the administration of antitoxin. The fatal case showed great swelling of the limb without any petechix, then failing vitality with weakening pulse and respiration. The poison acted, apparently, as a nervous depressant.

The before-mentioned camel fly, which comes in April and causes the death of camels unless these are driven away into the desert, will also occasionally bite man. The wound is painful, but no further consequences have been observed.

Nothing definite was learned concerning parasitism, particularly internal, nor about numerous other conditions which require extended and detailed medical observation.

\footnotetext{
${ }^{1}$ There were, in 1907 , according to the census returns, two insane in the Oasis.

' In 1907 four cases of leprosy were reported to the census from the whole Kharga Oasis.
} 


\section{VITAL STATISTICS OF THE KHARGA OASIS POPULATION IN I9O7}

The following data are based mainly on records furnished to the writer by the Kharga authorities, ${ }^{1}$ and on the last two Egyptian censuses.

In 1897 the total population of the Oasis, according to the Egyptian Census of that year, ${ }^{2}$ was 7,220 . At the beginning of 1907 , it was 8,424 , and at the beginning of 1909 , near $8,495 .^{\circ}$ The increase for the decade to 1907 amounted to 16.7 per cent, but during the last four years of the period it was in all probability, due to the absence of epidemics and hence lesser mortality, more rapid, being equal to 22 per cent per decade. This last is a rate of natural increase not equalled in any of the larger territorial groups of whites; but even the rate of 16.7 (or I6.I per cent), is a very high one, being reached among the whites only in some localized areas in Germany and one or two other countries. But this rate is almost exactly like that of Egypt as a whole, the net increase of population in that country from 1897 to 1907 being 16 per cent.

This relatively rapid augmentation in numbers of the Oasis people is due, as will be seen from later tables, on one hand to a large birth-rate and on the other to an unexpectedly moderate death-rate, in years free from epidemics.

The distribution of the population according to the four districts of the Kharga Oasis, and the population per dwelling, was in 1907 as follows:

\section{POPULATION OF THE KHARGA OASIS, AT THE BEGINNING OF 1907, ACCORDING TO THE DISTRICTS}

\begin{tabular}{|c|c|c|c|}
\hline & District & $\begin{array}{l}\text { Total number of } \\
\text { houses }\end{array}$ & $\begin{array}{l}\text { Total number of } \\
\text { inhabitants }\end{array}$ \\
\hline & . & .. $\quad 1,285$ & 5,322 \\
\hline ennah & $\ldots \ldots \ldots \ldots \ldots \ldots$, & 97 & 520 \\
\hline Boulac & $\cdots \cdots \cdots \cdots \cdots \cdots \cdots$, & I95 & I,0I6 \\
\hline Beris ... & n.................... & 452 & I,566 \\
\hline
\end{tabular}

(A little over 4.I to a dwelling.)

${ }^{1}$ The writer is especially indebted in this connection to M. Mohammed Cherif, the Maowen of the Oasis. The data were said to be entirely accurate.

${ }^{2}$ Récensement général de l'Egypte, Vol. 2, Le Caire, 1898, pp. 215, 274, etc. Ball (1. c., p. 46) and after him Beadnell ("An Egyptian Oasis," etc., p. 6I), give 7,856 . The difference between the number given by the census and that of Ball is not explainable, but the census number, judging by the increase of the population from 1904 to 1908 , is the more correct.

- The 1907 census of Egypt ( $4^{\circ}$, Cairo, I909), gives $4 \mathrm{I}$ less or 8,383, which would correspond to an increase for the decade of 16.1 per cent. As the figure given to the writer is substantiated by the detailed data on births and deaths, it will be used in preference. The difference, after all, is small. 
The above shows principally that overcrowding of dwellings is not, in general, prevalent at the Oasis.

As to the proportion of sexes in the Kharga population, the actual conditions could not be determined. The Egyptian census of 1897, however, gave 3,67 I males and 3,549 females, or 967 of the latter to each 1,000 of the former, and exactly the same proportion was found at that date in the whole of Egypt. The 1907 Egyptian census unfortunately seems to be less accurate. It gives for the Kharga Oasis 4,356 male and only 4,027 female individuals, which yields the ratio of but 925 females to I,000 males, while for whole Egypt the same ratio was at the same date 992 to 1,000 . The figures applying to the Oasis are evidently erroneous. They would indicate the existence of 108.2 males to each 100 females, which great disproportion is in no way sustained. It disagrees greatly with the data of the previous census. It is unequalled in Egypt or elsewhere, except in regions that have received immigrations of males, or at least an excess of males, which has not occurred in the Oasis. And it is opposed by the detailed birth and death records given in the following pages. It has been already shown that the I907 census figures as a whole differ from those furnished by the Oasis authorities, and they are evidently also unreliable in regard to the numbers of males and females in the population.

\section{BIRTHS AND DEATHS}

The details concerning the vital statistics of the Kharga Oasis, received from the local authorities, are not very extensive, nor equally complete for all the districts, nevertheless they show several interesting conditions.

VITAL STATISTICS OF THE KHARGA VILLAGE FOR FIVE YEARS

\begin{tabular}{|c|c|c|c|c|c|c|c|c|c|}
\hline \multirow{2}{*}{ Year } & \multirow{2}{*}{$\begin{array}{l}\text { Population } \\
\text { at the be- } \\
\text { ginning of } \\
\text { the year }\end{array}$} & \multicolumn{2}{|c|}{ Born } & \multirow{2}{*}{ Total } & \multirow{2}{*}{$\begin{array}{l}\text { Per } 1, \infty \infty \\
\text { of popu- } \\
\text { lation }\end{array}$} & \multicolumn{2}{|c|}{ Died } & \multirow{2}{*}{ Total } & \multirow{2}{*}{$\begin{array}{l}\text { Per } 1.000 \\
\text { of popu- } \\
\text { lation }\end{array}$} \\
\hline & & Males & Females & & & Males & Females & & \\
\hline 1904 & 4,978 & $\ldots$ & $\ldots$ & 254 & 51.0 & & ... & 138 & 27.7 \\
\hline 1905 & 5,094 & $12 \mathrm{I}$ & I I3 & 23 & 45.9 & 62 & 57 & II9 & 23.4 \\
\hline 1906 & 5,209 & 129 & I I9 & 24 & 47.6 & 73 & 62 & 135 & 25.9 \\
\hline 1907 & 5,322 & I 35 & 147 & 282 & 53.0 & $6 \mathrm{I}$ & 72 & 133 & 25.5 \\
\hline 1908 & $5,47 \mathrm{I}$ & 103 & II 4 & 217 & 39.7 & 192 & I60 & 352 & $64.3^{1}$ \\
\hline 1909 & 5,336 & $\cdots$ & $\cdots$ & $\cdots$ & $\cdots$ & $\cdots$ & $\cdots$ & ... & $\cdots$ \\
\hline Total. & $\ldots$ & $488^{2}$ & $493^{2}$ & $1235^{3}$ & $\ldots{ }^{3}$ & $388^{2}$ & $35 \mathrm{I}^{2}$ & $877^{3}$ & .... \\
\hline Avg.. & $\begin{array}{c}(5,215) \\
1904-7: \\
5151\end{array}$ & 122 & I 23 & 247 & 47.4 & $\ldots$ & $\cdots \cdot$ & $\begin{array}{l}175^{3} \\
131\end{array}$ & $\begin{array}{r}33.7^{3} \\
25.4\end{array}$ \\
\hline
\end{tabular}

${ }^{1}$ Epidemic of measles.

${ }^{2}$ For 4 years.

${ }^{8}$ For 5 years. 
VITAL STATISTICS OF THE GENNAF VILLAGE FOR FIVE YEARS

\begin{tabular}{|c|c|c|c|c|c|c|c|c|c|}
\hline \multirow{2}{*}{ Year } & \multirow{2}{*}{$\begin{array}{l}\text { Population } \\
\text { at the be- } \\
\text { ginning of } \\
\text { the year }\end{array}$} & \multicolumn{2}{|c|}{ Born } & \multirow{2}{*}{ Total } & \multirow{2}{*}{$\begin{array}{l}\text { Per } 1, \infty 00 \\
\text { of popu- } \\
\text { lation }\end{array}$} & \multicolumn{2}{|c|}{ Died } & \multirow{2}{*}{ Total } & \multirow{2}{*}{$\begin{array}{l}\text { Per 1,00o } \\
\text { of popu- } \\
\text { lation }\end{array}$} \\
\hline & & Males & Females & & & Males & Females & & \\
\hline I904 & 498 & .. & .. & 22 & 44.2 & .. & .. & 8 & 16.1 \\
\hline I905 & 512 & 9 & 12 & 21 & 41.0 & 7 & 9 & 16 & 31.2 \\
\hline 1906 & 517 & 4 & 8 & 12 & 23.2 & 5 & Io & 15 & 29.0 \\
\hline 1907 & 520 & 5 & I 2 & I 7 & 32.7 & 7 & 4 & II & 21.2 \\
\hline 1908 & 526 & 12 & IO & 22 & 41.8 & 3 & 5 & 8 & 15.2 \\
\hline 1909 & 540 & .. & .. & .. & $\ldots$ & .. & .. & .. & $\cdots$ \\
\hline Total. & $\ldots$ & $30^{1}$ & $42^{1}$ & $94^{2}$ & $\cdots$ & $22^{1}$ & $28^{1}$ & $58^{2}$ & $\ldots$ \\
\hline Avg.. & $5^{1} 5^{2}$ & 7.5 & 10.5 & 19 & 36.9 & 5.5 & 7 & II. 6 & 22.5 \\
\hline
\end{tabular}

For 4 years.

${ }^{2}$ For 5 years.

VITAL STATISTICS OF THE VILLAGES BOULAC AND BERIS FOR ONE YEAR, APRIL 1, 1907, TO APRIL 1, 1908

population at the beginning of $1907 \ldots 2,582$

Joint population at the beginning of $1908 \ldots .2,638$

Born :

Males ..................... 44

Females ..................... 45

Total ...................... 89

139

Rate, per 1000 of population, near ........ $34.5 \quad 35.5$

Died:

Males ..................... I7 5 I

Females .................... $22.66_{3}$

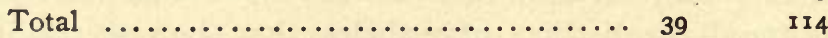

Rate, per 1000 of population, near ......... I5.I 29.5

The birth-rate at the Kharga Oasis, it is seen, is very high. It is higher than anywhere in Europe, except in some parts of Russia and in the Hungary group of nationalities. ${ }^{2}$ It harmonizes, however, with that of Egypt in general, where it averaged, among the native

${ }^{1}$ With an epidemic of measles in May at Beris.

${ }^{2}$ In Europe the birth-rate ranges, according to the most recent statistics, from approximately 22 per 1000 in France to a little over 40 in some of the groups of peoples under Hungary and to well over 40 in many parts of Russia. The death-rate ranges from a little less than 17 in Sweden to 29.9 per thousand (reports of 1904) in Russia, and the natural yearly increase per 1000 population from 0.7 in France to 14.0 in Germany. In the United States the birth-rate, while not exactly known, is probably less than 30 per 1000 ; the death-rate (in the registration area) approximately 18 ; and the yearly increment a little over 12 per 1000. 
Egyptians of the principal towns and for the seven years from IgoI to $1907,43.4$ per Ioo0 population. ${ }^{1}$

The large birth-rate at the Oasis indicates, outside of its significant relation to that of the Valley, two interesting conditions. It shows that the people are very prolific, notwithstanding the seemingly unfavorable factors of poor nourishment, the Oasis climate, the prevalent seclusion of the women, the very early marriages, with considerable intermarriage. It also shows that the people are well acclimatized to the locality, and suggests that the latter is probably not as unhealthful as unattractive.

The death-rate of the Oasis is also high when compared with that of the more civilized countries of white man. But it is not much higher than in those regions of Europe where the birth-rate is equally or nearly as high as it is at the Oasis, and is almost identical with that of Egypt as a whole.

The similarity of birth-rate and death-rate, and hence of natural increase in population, between the Oasis people and the rest of the Egyptians, is a fact of considerable importance. It indicates strongly a fundamental similarity of environmental and social conditions, and also a probable close similarity, at the present time at least, of the ethnic elements in the two regions.

The birth and death statistics afford also a closer insight into the proportion of sexes at the Oasis. During the 1905-08 period, covered by the detailed data, the proportion of males to females at birth and death has been as follows:

\section{SEX RATE AT THE KHARGA OASIS}

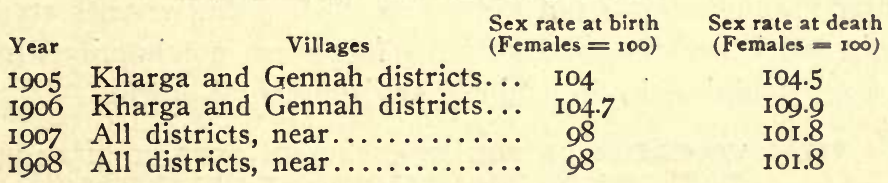

Evidently the relation of males to females, both born and died, differs to quite an extent from year to year, and also the same year

\begin{tabular}{|c|c|c|c|c|}
\hline 1 & Year & $\begin{array}{l}\text { Birth-rate pex } 1,000 \text { in the } \\
\text { principal towns of Egypt }\end{array}$ & $\begin{array}{l}\text { Death-rate per roo in the } \\
\text { principal towns of Egypt }\end{array}$ & $\begin{array}{l}\text { Natural Increase per } \\
\text { 1,000 population }\end{array}$ \\
\hline I9OI & ......... & 42.3 & 33.3 & 9.0 \\
\hline 1902 & $\ldots \ldots \ldots$ & 42.7 & 36.7 & 6.0 \\
\hline I903 & ........ & 42.5 & 32.0 & 10.5 \\
\hline 1904 & ......... & 44.I & 38.2 & 5.9 \\
\hline 1905 & $\ldots \ldots \ldots$ & 43.8 & 34.2 & 9.6 \\
\hline 1906 & ......... & 44.7 & 33.9 & 10.8 \\
\hline 1907 & ......... & 43.7 & 36.7 & 7.0 \\
\hline Aver & age $\ldots . .$. & 43.4 & 35.0 & 8.4 \\
\hline
\end{tabular}

"Births and Deaths in the Principal Towns of Egypt During the Years I90I-I906 (and I907)," Fol. Cairo, I907-'08. 
in the different villages-as it does occasionally among smaller groups of other peoples. But the whole of the data shows conditions in favor of the relative numbers of the females, which must be regarded, from what is known on the subject, as a favorable breeding condition. The average proportion of males to females at birth among the whites ranges between 105 and 106 to $100,{ }^{1}$ or, in round numbers, there are 94 to 95 females to each roo males. In the American negro, however, the proportion rises to 99.I females to every 100 males, which is the highest proportion thus far recorded for any people." In the principal towns of Egypt, in 1909, the proportion of sexes at birth among the native population was 103.3 males to each 100 females, or 96.8 females to each 100 males, which is probably very near to the average condition for the last decade at Kharga.

The next tables give the movement in population in the Kharga village month by month, and that in Kharga and Gennah by the quarter of the year. It will be observed that births predominate somewhat in April-June, corresponding to conception in AugustOctober, which latter is a season of the date harvest and relative plenty at the Oasis, and that the least proportion occurs in the January-March quarter; yet the differences are not great, especially if the probable errors of the data be discounted.

More definite seasonal differences, however, are observed in the mortality, which is greatest in the last and then in the first quarters of the year, and least from July to September. The sudden rise from the late summer and early fall minimum to the subsequent winter maximum was not known of during the writer's stay at the Oasis and hence the causes of the fact were not inquired into; but they are doubtless in the main of environmental origin.

\section{VITAL STATISTICS OF THE KHARGA AND GENNAH VILIJAGES FROM 1905 TO 1908, INCLUSIYE, BY QUARTERS}

\section{Births Deaths}

Average permonth Average permonth

January-March ............... I9.9

II.I

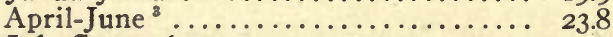

I0.4

July-September .............. 2I.I

October-December ............... 22.8

9.9

I4.0

${ }^{1}$ Nichols, J. B.: The Numerical Proportion of the Sexes at Birth. Mem. Anthrop. Assoc. Vol. I, part 4, Lancaster, Pą., I907, pp. 249-300.

'It would be interesting to ascertain whether or not this is a racial trait, or one applicable also to the Soudanese and Nubians, in which case the admixture of the latter into the Egyptian and the Kharga Oasis people might possibly account for the relatively high female birth-rate among these.

${ }^{8}$ The three months epidemic of 1908 at Kharga, which will be noticed in the next table, excluded. 
BIRTHS AND DEATHS AT THE KHARGA VILLAGE FOR FOUR YEARS BY MONTHS

\begin{tabular}{|c|c|c|c|c|c|c|c|c|c|c|c|c|}
\hline \multirow[b]{2}{*}{ Month } & \multicolumn{3}{|c|}{8905} & \multicolumn{3}{|c|}{$\mathbf{x} 906$} & \multicolumn{3}{|c|}{1907} & \multicolumn{3}{|c|}{$x 908$} \\
\hline & $\frac{0}{\pi}$ & 䒕 & ङึ & 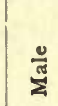 & 递 & 丞 & $\stackrel{\frac{0}{\pi}}{\Sigma}$ & 㫕 & & $\frac{0}{\pi}$ & 峁 & ङ్ \\
\hline January .......... & 9 & II & 20 & 9 & 5 & 14 & 15 & I3 & 28 & 9 & I2 & 21 \\
\hline February ...... & 9 & I 5 & 24 & 8 & 8 & 16 & I4 & 8 & 22 & 6 & 4 & 10 \\
\hline March ............ & 13 & 5 & 18 & 8 & I I & 19 & 4 & 8 & 12 & II & 6 & 17 \\
\hline 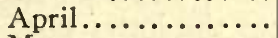 & 8 & I 5 & 23 & 8 & 12 & 20 & II & 13 & 24 & 8 & I I & 19 \\
\hline 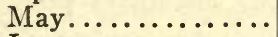 & 12 & I 2 & 24 & I3 & 12 & 25 & I9 & II & 30 & 16 & 9 & 25 \\
\hline June $\ldots \ldots \ldots \ldots \ldots$ & II & I4 & 25 & I3 & 6 & 19 & 5 & 9 & 14 & Io & 12 & 22 \\
\hline 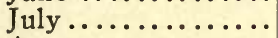 & 7 & 6 & 13 & 8 & IO & 18 & 14 & 14 & 28 & 6 & I5 & 21 \\
\hline August ............ & 5 & 7 & 12 & I 2 & 8 & 20 & 9 & I4 & 23 & 7 & 9 & 16 \\
\hline September......... & 14 & 4 & 18 & 8 & I0 & 18 & 12 & 18 & 30 & 8 & 9 & 17 \\
\hline October........ & II & 6 & 17 & I6 & I6 & 32 & IO & I8 & 28 & 7 & 8 & 15 \\
\hline November......... & 12 & I0 & 22 & I4 & I2 & 26 & I4 & 14 & 28 & 8 & Io & 18 \\
\hline December......... & IO & 8 & 18 & 12 & 9 & 21 & & 7 & 15 & 7 & 9 & 16 \\
\hline Total... & I 21 & I I 3 & 234 & 129 & II 9 & 248 & I 35 & 147 & 282 & 103 & II 4 & 217 \\
\hline
\end{tabular}

DEATHS

\begin{tabular}{|c|c|c|c|c|c|c|c|c|c|c|c|c|}
\hline \multirow[b]{2}{*}{ Month } & \multicolumn{3}{|c|}{ x905 } & \multicolumn{3}{|c|}{1906} & \multicolumn{3}{|c|}{1907} & \multicolumn{3}{|c|}{1908} \\
\hline & 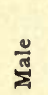 & है & 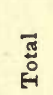 & $\frac{0}{\frac{x}{z}}$ & 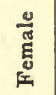 & ֻٓ & $\stackrel{\frac{0}{\pi}}{\Sigma}$ & 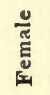 & 犬ूँّ & స్ㅠ & 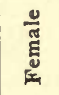 & 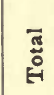 \\
\hline January . & 9 & 5 & 14 & 10 & 2 & 12 & 6 & 7 & 13 & 3 & 2 & \\
\hline February ...... & 3 & 4 & 7 & 3 & 6 & 9 & 6 & 7 & 13 & 5 & 6 & 11 \\
\hline March ............ & 3 & 4 & 7 & 7 & 6 & 13 & 2 & 8 & 10 & 6 & I & 7 \\
\hline April........ & 7 & 2 & 9 & 7 & 6 & 13 & 3 & 6 & 9 & 46 & 48 & 94 \\
\hline May.......... & 5 & 7 & 12 & 6 & 7 & 13 & 3 & 6 & 9 & 90 & 56 & 146 \\
\hline June.......... & 4 & 6 & 10 & 3 & 4 & 7 & 3 & 2 & 5 & 17 & 16 & 33 \\
\hline July $\ldots \ldots \ldots \ldots \ldots$ & 3 & 6 & 9 & 6 & I & 7 & 5 & 6 & 11 & 5 & 9 & 14 \\
\hline August ....... & 3 & 3 & 6 & 4 & 6 . & 10 & 4 & 4 & 8 & 2 & 4 & 6 \\
\hline September.... & 4 & 6 & 10 & 7 & 4 & 11 & 3 & 5 & 8 & 5 & 5 & 10 \\
\hline October....... & 5 & 4 & 9 & 9 & 6 & 15 & 4 & 6 & 10 & 6 & 2 & 8 \\
\hline November..... & 8 & 6 & 14 & 4 & 8 & 12 & 14 & 5 & 19 & 4 & 6 & 10 \\
\hline December.... & 8 & 4 & 12 & 7 & 6 & 13 & & I0 & 18 & 3 & 5 & \\
\hline Total......... & 62 & 57 & 119 & 73 & 62 & 135 & $6 r$ & 72 & 133 & I92 & I60 & 352 \\
\hline
\end{tabular}

\section{RÉSUMÉ OF VITAL STATISTICS OF THE KHARGA OASIS}

To summarize, the vital statistics data of the Kharga Oasis have shown: (I) A steady high birth-rate; (2) barring years with epidemics, a moderately high death-rate; (3) a relatively rapid rate of natural increase in population; (4) a slight seasonal difference in proportion of births, and a more marked one in proportion of deaths ; (5) a relatively high proportion, both at birth and in population, of females; and (6) a very close similarity in all these items to the conditions in Egypt in general. 


\section{PHYSIOLOGICAL OBSERVATIONS ON THE KHARGA OASIS NATIVES}

The people of the Oasis, while ignorant, and therefore apprehensive and superstitious, were found on the whole to be fairly intelligent. They are mild, polite, not very energetic or enterprising, but not idlers. They are in general poorly nourished and show the effects of that condition in their lack of initiative and diminished strength as well as endurance, which conditions are marked in all their activities.

The observations to be recorded were made during the latter part of February, which is a season quite free from climatic extremes and a healthier one than other parts of the year.

The tests undertaken were the same as those on Indians, reported by the writer in 1908, and were carried out with the same instruments and in like manner, so that these two series of data are entirely comparable. They relate to the pulse, respiration, temperature, and manual with arm strength of the people, and extend to r 50 adult males. The subjects were mainly from the Kharga village and nearby settlements. They were all free, it should be stated again, from negro admixture, as far as ascertainable, and free from any complaints or disease which would incapacitate them for work. They were examined as a rule only after being rested and in the absence of exciting circumstances. The men took to the examination kindly; if any were found in whom the state of the tongue or other organs indicated a systemic disarrangement of any consequence, they were excluded; and with the other precautions taken, it seems safe to say that the results which will be given in the following pages, represent fairly the normal or average conditions at the Oasis, at that period. The examination of the women and children would have added materially to the interest and value of these tests, but for reasons already stated was impossible.

\section{PULSE ${ }^{2}$}

The results on 94 healthy male individuals, of all ages, as shown in the accompanying table, give an average which is by 4 or 5 beats

\footnotetext{
${ }^{2}$ Hrdlička, A.: Physiological and Medical Observations Among the Indians of Southwestern United States and Northern Mexico. Bull. 34, Bureau Amer. Ethnology, $8^{\circ}$, Washington, I908, pp. I-460.

"Compare data in writer's "Physiological and Medical Observations, etc., pp. I38 et seq.
} 
per minute higher than the general average in male whites, and from 9 to 19 beats per minute higher than shown by various tribes of the American native. The most common pulse-rates at Kharga are those between $7 \mathrm{I}$ and 80.

KHARGA OASIS, MEN: PULSE (PER MINUTE) ${ }^{1}$

Number of observations: 94.

Average: 76 . (Ist series of $46: 77.5 ; 2 \mathrm{~d}$ series of $48: 74.5$.)

Median: 75 . Mode: 72 .

Minimum: 54. Maximum: 105.

Table of frequencies:

\begin{tabular}{|c|c|c|c|c|c|c|c|c|c|c|c|}
\hline & $\begin{array}{l}\text { 우 } \\
\text { 맘 }\end{array}$ & $\begin{array}{l}\text { ర } \\
8\end{array}$ & $\begin{array}{l}8 \\
1 \\
\text { in }\end{array}$ & $\begin{array}{l}\mathbb{N} \\
i\end{array}$ & $\begin{array}{l}2 \\
1 \\
\text { in }\end{array}$ & $\begin{array}{l}\infty \\
\infty \\
1 \\
\infty\end{array}$ & $\begin{array}{l}\infty \\
1 \\
\infty \\
\infty\end{array}$ & $\begin{array}{l}\text { ó } \\
\text { \&े }\end{array}$ & $\begin{array}{l}\text { oิ } \\
\text { นn }\end{array}$ & 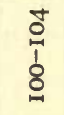 & ณ \\
\hline $\begin{array}{l}\text { Number of cases.... } \\
\text { Per cent.......... }\end{array}$ & $\begin{array}{l}\text { I } \\
1.1\end{array}$ & $\begin{array}{l}8 \\
8.5\end{array}$ & $\begin{array}{l}8 \\
8.5\end{array}$ & $\begin{array}{l}29 \\
30.8\end{array}$ & $\begin{array}{l}21 \\
22.3\end{array}$ & $\begin{array}{l}14 \\
14.9\end{array}$ & $\begin{array}{l}2 \\
2.1\end{array}$ & $\begin{array}{l}8 \\
8.5\end{array}$ & $\begin{array}{l}\mathrm{I} \\
1.1\end{array}$ & $\begin{array}{l}\mathrm{I} \\
1.1\end{array}$ & $\begin{array}{l}\text { I } \\
1.1\end{array}$ \\
\hline
\end{tabular}

${ }^{1}$ In sitting position.

The causes of the frequency of a relatively rapid pulse and hence heart-beat at the Oasis are not easy to determine. The phenomenon is not due to rarefied air, for the Oasis lies, on the average, less than Ioo meters above the sea-level. It is in no case connected with alcoholism, for that vice is practically absent, ${ }^{1}$ nor with any abuse or even the use of coffee, tea or tobacco, which articles are still to a large extent luxuries in the Oasis. There are also no drug habits. The general environmental conditions, finally, are much like those in the American deserts, and in the latter no accelerating influence has been manifested thus far on the slow pulse of the Indian. It therefore seems that the relatively high pulse rate at the Oasis is in the main a long established, hereditary condition.

Further inquiries, however, were made into the subject, to show what, if any, relation the phenomenon had to the most important conditions of the body.

${ }^{1}$ The natives make a sort of beer from the sap of the date-palm and a stronger liquor from the dates, but the quantity made is not large and is limited, particularly in the latter case, in season. According to Beadnell (An Egyptian Oasis, p. 218), the weaker liquor is called "lagmi." It "has a peculiar insipid taste. It is obtained by making a deep incision in the top of the date-palm, the liquid oozing out and being collected in a vessel, generally made of the rind of a gourd. As much as ro quarts can be obtained in a day, and the tree may be bled once or twice a month without sustaining any harm; the operation may, in fact, prove of considerable benefit to a sickly palm." 
A reference to the table on page 27 will show that, so far as these data reach, no clear difference is appreciable between the pulse-rate of the youngest and oldest adults examined. The series, however, does not comprise many individuals above 55 years of age (estimated), and is in general too limited for definite conclusions. One point is evident, and that is the fact that age effects on the pulserate up to the fifty-fifth year, if they exist, are irregular at the Oasis.

A more marked relation was detected between the pulse-rate and the stature. Taking the healthy adults up to 50 years of age, the I 5 men of the highest stature give an average pulse-rate 2.9 beats higher than the 20 of the lowest stature. The details given on the table on page 28 show especially the frequent occurrence of subaverage pulse-rate in those of short height. The association of a higher average pulse-rate with tall statures has been observed in whites $^{2}$ and also in Indians, ${ }^{2}$ so that it is probably a more or less irregular but prevalent physiological condition. What is the real direct cause of the pulse acceleration in those of tall stature, is as yet somewhat problematical.

Still another condition inquired into was the relation of the pulserate to vigor, as indicated by the tests of strength. The i8 weakest but healthy men gave the average pulse-rate of 74.5 , the 16 strongest 75.4. Both of these figures are curiously below the general average $(=76)$. The difference between the two series is small, but there are indications that it is not accidental (see table on page 28). The matter is, however, complicated by the fact that in many instances greater muscular strength corresponds with taller stature. Some further light will be thrown on these points by the results of tests of other functions.

The relation of pulse to respiration and body temperature will be referred to under these headings.

\section{RESPIRATION}

The respiration-rate averages in the healthy Kharga men, as seen from the figures below, I8.4 per minute, which is slightly above the general averages in both the whites and the Indian. ${ }^{3}$ The difference,

\footnotetext{
${ }^{1}$ Volkmann, A. W.: Die Haemodynamik nach Versuchen, $8^{\circ}, 1850$, p. 429 et seq.

${ }^{2}$ Hrdlička, A.: Physiological and Medical Observations, etc., p. I4I et seq.

${ }^{3}$ Compare data in Vierordt, H., Anatomische, Physiologische und Physikalische Daten und Tabellen, 8. Jena. I893, p. I66. Also Smith, E.: Trans. Roy. Med. \& Chir. Society, London, Vol. 39, 1856.
} 
amounting to about one respiration more every two minutes, is so small that, were it not for the simultaneous and better defined excess in pulse-rate, it could be disregarded. As it is, it is probably an expression of correlated action of the lungs and the heart.

KHARGA OASIS, MEN: RESPIRATION (PER MINUTE)2

Number of observations : 94.

Average: 18.4 . (Ist series of $46: 18.6 ; 2 \mathrm{~d}$ series of $48: 18.3$. )

Median: 18 . Mode: 18.

Minimum: 14. Maximum: 24.

Table of frequencies:

\begin{tabular}{|c|c|c|c|c|c|c|}
\hline & 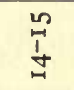 & $\hat{\vec{\jmath}}$ & 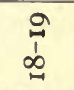 & $\begin{array}{l}\vec{N} \\
\mathfrak{d}\end{array}$ & $\begin{array}{l}\tilde{n} \\
\tilde{d} \\
\tilde{d}\end{array}$ & a \\
\hline 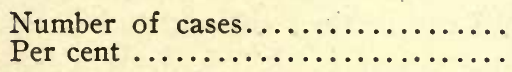 & $\begin{array}{c}12 \\
12.8\end{array}$ & $\begin{array}{c}18 \\
19.2\end{array}$ & $\begin{array}{ll}33 \\
35.1\end{array}$ & $\begin{array}{l}18 \\
19.2\end{array}$ & $\begin{array}{c}9 \\
9.6\end{array}$ & $\begin{array}{c}4 \\
4.3\end{array}$ \\
\hline
\end{tabular}

${ }^{1}$ Sitting, at rest.

The numerical relation of the pulse-beats to respiration averages 4.I3, which is practically the same as in whites.

In regard to age, the youngest adults of the series examined show (see table on page 27 ) a slightly greater average ( +0.4 per minute) than the oldest ones. A similar condition was observed by the writer in the Indians and it also exists in the whites. As a result of this and of the frequently observed more rapid pulse in old age, the pulse-beat: respiration ratio is slightly higher in senility than earlier in adult life.

As to stature, the shortest healthy men up to 50 years of age gave a lower average by nearly one breath a minute than the taller ones (for details see table on page 28). This stands again in correlation with the lower average pulse in those of short stature, but it is not possible to say whether the condition is characteristic of the people of the Oasis, or is merely an accidental feature of this group. How far it may be true of other ethnic groups is as yet uncertain.

The pulse-respiration ratio in the two groups remains almost identical (4.18 for the short, 4.16 for the tall), showing that there has. been a harmonious response in this line of the two functions.

A similar condition to that in the shortest adult prevails also in those who are weakest muscularly-the series give a perceptibly lower average rate of respiration (as they did of pulse-rate) than that of the strongest individuals (see details in table on page 28). The difference of the averages amounts to 0.7 of a respiration per minute in favor of the strongest. The rate in the latter is also 
higher than the general average. The pulse-respiration ratio, however, is relatively small in the "strongest," amounting to only 3.97 (in the weakest $=4.07$ ). This condition of subaverage pulse-rate with above-average respiration-rate in the Kharga "strongest" group is not understood. As a great many individual elements enter into every expression of these series and as the latter are not large enough to submerge the effects of all such conditions, the discrepancy may be accidental. It is regrettable that no detailed extensive data of similar nature exist as yet on the whites, the subject being far from exhausted in that race alone.

\section{TEMPERATURE}

The temperature of the body was taken in every case with verified thermometers, under the tongue, with the subject sitting, and with the instrument in place for at least five minutes. All the tests were made between 9 A. M. and 5 P. M. and were about equally distributed over the intervening hours. The results are as follows:

KHARGA OASIS, MEN: TEMPERATURE

Number of observations: 95 .

Average: $98.6^{\circ} \mathrm{F}$. (Ist series of $47: 98.7^{\circ}$; $2 \mathrm{~d}$ series of $48: 98.5^{\circ}$.)

Median: $98.7^{\circ}$. Mode: 2 groups, $98.5^{\circ}, 98.9^{\circ}$.

Minimum: $96.2^{\circ}$. Maximum: $99.9^{\circ}$.

Table of frequencies:

\begin{tabular}{|c|c|c|c|c|c|c|c|c|}
\hline & $\begin{array}{l}\text { ì. } \\
\text { ช் }\end{array}$ & $\begin{array}{l}\circ \\
0 \\
8 \\
i \\
\text { in } \\
\text { ட் }\end{array}$ & 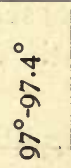 & $\begin{array}{l}\circ \\
\stackrel{0}{0} \\
\hat{i} \\
\text { in } \\
\text { ஸे }\end{array}$ & 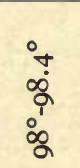 & $\begin{array}{l}0 \\
0 \\
o \infty \\
o \\
\text { ô } \\
\text { in } \\
\infty \\
\infty\end{array}$ & $\begin{array}{l}\text { \% } \\
\text { ò } \\
\text { ' } \\
8\end{array}$ & $\begin{array}{l}\circ \\
\text { ó } \\
\text { \&் } \\
\text { in } \\
\text { in } \\
\text { \&் }\end{array}$ \\
\hline $\begin{array}{l}\text { Number of cases....... } \\
\text { Per cent } . . . \ldots \ldots \ldots\end{array}$ & $\cdot \begin{array}{c}1 \\
1.1\end{array}$ & 2.1 & 4.2 & $\begin{array}{c}12 \\
12.6\end{array}$ & $\begin{array}{l}14 \\
14.7\end{array}$ & $\begin{array}{l}29 \\
30.5\end{array}$ & $\begin{array}{c}25 \\
26.3\end{array}$ & $\begin{array}{c}8 \\
8.4\end{array}$ \\
\hline
\end{tabular}

The average temperature in the European amounts to about $98.9^{\circ}$ $\mathrm{F} .\left(37.2^{\circ} \mathrm{C}.\right)$; the male Indians have given the writer averages, according to tribes, varying from 98.1 to 98.8 ; the Kharga males show $98.6^{\circ}$.

In the whites each $10^{\circ} \mathrm{F}$. temperature correspond, on the average, to 7.28 pulse-beats and 1.82 respirations; in the Indians, to 6.40 pulse-beats and 1.78 respirations; and in the Kharga natives to $7.7 \mathrm{I}$ pulse-beats and 1.87 respirations. These are differences well beyond the limits of the probable error, and hence are of significance, though their exact explanation can hardly as yet be attempted. The temperature of the Oasis men is, plainly, low in relation to both pulse and 
respiration as compared with the whites, and especially with the Indians. It is also absolutely somewhat lower than in the whites. This condition means probably, in the main, a somewhat lower intensity in the Kharga natives of general metabolism, which agrees well with the poorer nutrition of a large proportion of the Oasis population; but it is doubtless also influenced by a greater heat radiation from the skin, due to the subtropical climate of the Oasis.

As to age, the oldest Kharga adults show, as seen in the next table, a slightly lower average temperature than the youngest ones. The difference would be quite insignificant, however, except for the fact that it agrees with what is known in this respect of whites and what

\section{KHARGA OASIS: PULSE, RESPIRATION, AND TEMPERATURE IN RELATION TO AGE}

\begin{tabular}{|c|c|c|c|c|c|c|c|}
\hline \multicolumn{4}{|c|}{ Fifteen youngest men: $21-26$ years } & \multicolumn{4}{|c|}{ Fourteen oldest men: $55-65$ years } \\
\hline Age & $\begin{array}{l}\text { Pulse (sit- } \\
\text { ting) per } \\
\text { minute }\end{array}$ & $\begin{array}{c}\text { Respiration } \\
\text { (sitting) } \\
\text { per minute }\end{array}$ & $\begin{array}{l}\text { Tempera- } \\
\text { ture (sub- } \\
\text { lingua), } \\
\text { grades }\end{array}$ & Age & $\begin{array}{l}\text { Pulse (sit- } \\
\text { ting) per } \\
\text { minute }\end{array}$ & $\begin{array}{l}\text { Respiration } \\
\text { (sitting) } \\
\text { per minute }\end{array}$ & $\begin{array}{l}\text { Tempera- } \\
\text { ture (sub- } \\
\text { lingua), } \\
\text { grades }\end{array}$ \\
\hline Years & & & ${ }^{\circ} F$ & Years & & & ${ }^{\circ} F$ \\
\hline $2 \mathrm{I}$ & 72 & I8 & 98.0 & $55^{1}$ & (100) & (I7) & $(98.8)$ \\
\hline 22 & $8 \mathrm{I}$ & 20 & 98.7 & 55 & 92 & 16 & 98.6 \\
\hline 23 & 72 & 20 & 97.4 & $55^{2}$ & 62 & 20 & 97.9 \\
\hline $24^{1}$ & 75 & I5 & $99 . \mathrm{I}$ & $55^{3}$ & 78 & I9 & 98.3 \\
\hline $24^{2}$ & (72) & (16) & $(96.2)$ & 55 & 72 & 17 & 98.2 \\
\hline $24^{3}$ & $(84)$ & (19) & $(99.2)$ & $55^{4}$ & 90 & 22 & 99.2 \\
\hline 24 & 78 & 20 & 99.4 & 55 & 69 & I6 & 97.6 \\
\hline $24^{4}$ & 96 & I9 & 99.3 & 55 & 60 & I 5 & 97.7 \\
\hline $25^{5}$ & $8 \mathrm{I}$ & 22 & 97.7 & $55^{5}$ & 84 & 19 & 99.3 \\
\hline 25 & 74 & I8 & 98.4 & $58^{6}$ & 72 & I8 & 98.4 \\
\hline 25 & 78 & I9 & 99. I & 60 & 72 & 20 & 98.7 \\
\hline 26 & 73 & $2 \mathrm{I}$ & 99.2 & $60^{7}$ & (72) & (22) & $(99.6)$ \\
\hline $26^{6}$ & 66 & 18 & 98.5 & $60^{8}$ & 72 & I4 & 98.6 \\
\hline 26 & 84 & I8 & 98.9 & $65^{9}$ & 90 & 20 & 99.4 \\
\hline 26 & 72 & I8 & 98.8 & & & & \\
\hline
\end{tabular}

Averages (exclusive of the cases in parentheses):

\begin{tabular}{l|l|l|l|l|l|l|l|}
\hline 24.3 & 75.5 & 18.9 & 98.7 & 57 & 76.1 & 18.5 & 98.5 \\
\hline
\end{tabular}

13 P. M.; tongue slightly whitish.

2 Io A. M.; low temperature possibly due to hunger.

${ }^{3}$ Sore throat.

II.55 A. M.; tongue somewhat coated.

${ }^{5}$ Io.40 A. M.; tongue slightly coated.

I2.50 P. M.; tongue slightly coated.
${ }^{1}$ Sore throat.

2 2.I5 P. M.; tongue slightly coated.

${ }^{3}$ 9.40 A. M.; tongue yellowish.

4.Io P. M.; tongue yellowish coated.

I.5O P. M.; tongue slightly coated.

iI.50 A. M.; tongue slightly coated.

${ }^{7}$ I0.25 A. M.; tongue all coated.

${ }^{3}$ I2.30 P. M.; cause of slow respiration?

3.I5 P. M.; tongue yellow-coated. 
has been observed in the Indians. The smallness of the difference is due principally to the fact that no really senile or very old individuals are included in the Kharga series.

KHARGA OASIS: PULSE, RESPIRATION, AND TEMPERATURE IN RELATION TO EXTREMES OF STATURE ${ }^{1}$

\begin{tabular}{|c|c|c|c|c|c|c|c|}
\hline \multicolumn{4}{|c|}{$\begin{array}{c}20 \text { shortest men, } 152.3-159.8 \mathrm{~cm} \text {. } \\
\text { (average age } 33.9 \text { years) }\end{array}$} & \multicolumn{4}{|c|}{$\begin{array}{l}{ }^{1} \text { tallest men, } 167.1-173.8 \mathrm{~cm} \text {. } \\
\text { (average age } 39.7 \text { years) }\end{array}$} \\
\hline Stature & $\begin{array}{c}\text { Pulse } \\
\text { (sitting) } \\
\text { per minute }\end{array}$ & $\begin{array}{l}\text { Respiration } \\
\text { (sitting) } \\
\text { per minute }\end{array}$ & $\begin{array}{c}\text { Temper- } \\
\text { ature } \\
\text { (sub-lingua) } \\
5 \text { minutes } \\
\text { exposure }\end{array}$ & Stature & $\begin{array}{c}\text { Pulse } \\
\text { (sitting) } \\
\text { per minute }\end{array}$ & $\begin{array}{l}\text { Respiration } \\
\text { (sitting) } \\
\text { per minute }\end{array}$ & $\begin{array}{c}\text { Temper- } \\
\text { ature } \\
\text { (sub-lingua) } \\
5 \text { minutes } \\
\text { exposure }\end{array}$ \\
\hline $\mathrm{cm}$. & & & ${ }^{\circ} \mathrm{F}$. & cme. & & & ${ }^{\circ} \mathrm{F}$. \\
\hline I 52.3 & 78 & I8 & 97.9 & I67.I & 78 & I8 & 98.3 \\
\hline I 53.6 & 78 & I6 & 99.2 & 167.3 & 78 & 22 & 98.5 \\
\hline I 55.7 & 65 & I4 & 98.3 & I68. 2 & 78 & 22 & 98.3 \\
\hline I55.9 & 72 & 20 & 98.9 & I68. 3 & 72 & I7 & $98 . \mathrm{I}$ \\
\hline I 56.0 & 77 & I 7 & 97.9 & I68. 8 & 76 & $2 \mathrm{I}$ & 98.9 \\
\hline I 57.5 & $8 \mathrm{I}$ & 22 & 97.7 & I68.9 & 82 & 17 & 99.2 \\
\hline I 57.8 & 72 & 20 & 97.4 & I69. 4 & 68 & I8 & 98.5 \\
\hline I 58.3 & 92 & 22 & 99.5 & 169.4 & 84 & I9 & 98.9 \\
\hline I 58.4 & 70 & I6 & 97.8 & 170.5 & 82 & 18 & 98.8 \\
\hline I 58.5 & 74 & 20 & 99.2 & I 71.3 & 76 & I 8 & $99 . I$ \\
\hline I 58.5 & 70 & I8 & 99.2 & 172.2 & 92 & I6 & 98.6 \\
\hline I 58.7 & 72 & $2 I$ & 98.9 & I 72.4 & 71 & I 8 & 99.1 \\
\hline I 58.7 & 76 & I6 & 98.5 & 172.5 & 70 & I8 & 98.1 \\
\hline I 58.8 & 72 & I8 & 98.0 & 172.7 & 82 & $2 I$ & 98.2 \\
\hline I 59.3 & 80 & I5 & $99 \cdot 3$ & I 73.8 & 78 & I 8 & 99.6 \\
\hline I 59.4 & 78 & I 5 & 98.9 & & & & \\
\hline I 59.5 & 69 & 18 & 98.7 & & & & \\
\hline I 59.6 & 72 & I6 & $97 \cdot 5$ & & & & \\
\hline I 59.7 & 78 & 20 & 99.4 & & & & \\
\hline I 59.8 & 72 & 16 & 96.2 & & & & \\
\hline
\end{tabular}

Averages :

\begin{tabular}{l|l|l|l|l|l|l|l|}
157.8 & 74.9 & 17.9 & 98.4 & 170.2 & 77.8 & 18.7 & 98.7 \\
\hline
\end{tabular}

${ }^{1}$ In adult healthy men of not more than 50 years of age.

KHARGA OASIS: PULSE, RESPIRATION, AND TEMPERATURE IN RELATION TO VIGOR

\begin{tabular}{|c|c|c|c|c|c|c|c|}
\hline \multicolumn{4}{|c|}{18 weakest healthy men (up to so years of age) } & \multicolumn{4}{|c|}{16 strongest healthy men (up to 50 years of age) } \\
\hline $\begin{array}{l}\text { Average } \\
\text { pressure } \\
\text { force in } \\
\text { right hand }\end{array}$ & $\begin{array}{c}\text { Average } \\
\text { pulse (sit- } \\
\text { ting) }\end{array}$ & $\begin{array}{c}\text { Average } \\
\text { respiration } \\
\text { (sitting) }\end{array}$ & $\begin{array}{c}\text { Average } \\
\text { temperature } \\
\text { (sub-lingua) }\end{array}$ & $\begin{array}{l}\text { Average } \\
\text { pressure } \\
\text { force in } \\
\text { right hand }\end{array}$ & $\begin{array}{c}\text { Average } \\
\text { pulse (sit- } \\
\text { ting) }\end{array}$ & $\begin{array}{l}\text { Average } \\
\text { respiration } \\
\text { (sitting) }\end{array}$ & $\begin{array}{c}\text { Average } \\
\text { temperature } \\
\text { (sub-lingua) }\end{array}$ \\
\hline$\frac{K g}{28}$ & $\underset{74.5}{\text { Permin }}$ & $\begin{array}{c}\text { Permin. } \\
\text { I } 8.3\end{array}$ & $\begin{array}{l}\circ F . \\
98.3\end{array}$ & $\underset{4 \mathrm{I}}{K g}$ & $\underset{75.4}{\text { Permin }}$ & $\underset{\text { I9.0 }}{\text { Permin. }}$ & ${ }^{\circ} F .6$ \\
\hline
\end{tabular}


In relation to stature, the temperature is on the average higher in the "tallest" than it is in the "shortest" Kharga natives. And the temperature goes hand in hand in these groups with both pulse and respiration. The "shortest" males at the Oasis show thus on the average a somewhat less active metabolism, as well as a slower heart and slower respiration. They manifest lesser vitality, which suggests a causal relation between at least some of the low statures at the Oasis and the agencies which condition lowered vitality. The main of these conditions are probably chronic malnutrition, and protracted effects during the developmental stage of life of malaria or other systemic disorders. The tallest Kharga men are, on the average, of a distinctly superior vitality.

Muscular potency shows similar relation to temperature as age and stature: It is in general perceptibly below the average in those who give low temperature, and both go together with sub-average pulse rate as well as respiration-rate. The individuals of the best muscular vigor show mean temperature, with slightly sub-average pulse, but somewhat above average respiration. A larger series of observations would in these respects be very desirable.

\section{MUSCULAR STRENGTH}

The tests of muscular strength were those of pressure in each hand and traction. ${ }^{1}$ They were made by Mathieu's dynamometer and represent the maximum exertion of the subjects determined in two to four consecutive trials. The hands and arms were in every case held free from the body and cases with crippled or sore fingers, hands or arms were excluded. There was no unwillingness or lack of interest on the part of those examined in making the tests, so that the record obtained may be regarded as fairly representative of the true condition in regard to muscular strength of the Kharga men.

The results are seen in the following tables.

\footnotetext{
${ }^{1}$ With the medius of each hand linked into the arch of the instrument at its small end and the arms held not higher than the chin.
} 


\section{KHARGA OASIS, MEN: PRESSURE FORCE IN THE HANDS 1}

Number of observations in each hand: II5.

Average, right hand: 33.8 ; left hand: $3 I . I \mathrm{~kg}$. (Ist 50: right hand 33.4 , left hand $30.9 ; 2 \mathrm{~d} 50$ : right hand 33.4 , left hand 3 I.2.)

Median: right hand 33 , left hand 31 . Modes : right hand 28 and 34 , left hand $3 \mathrm{I}$.

Minimum : right hand 24, left hand 21 . Maximum : right hand 49 , left hand 45 . Table of frequencies:

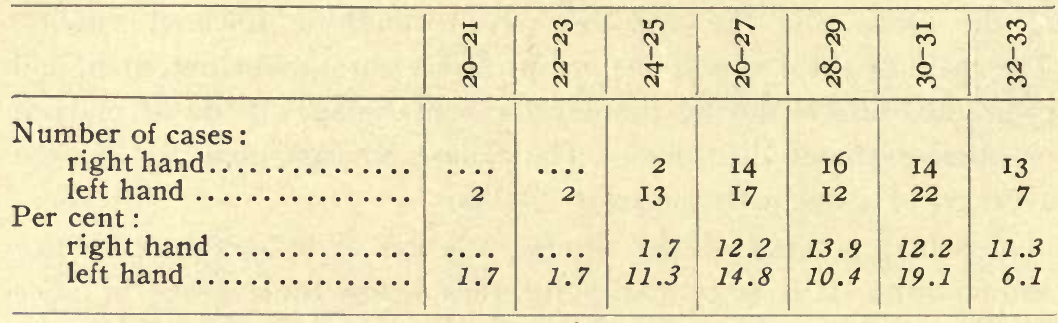

\begin{tabular}{|c|c|c|c|c|c|c|c|c|}
\hline & 站 & $\hat{\tilde{b}}$ & $\begin{array}{l}\text { pి } \\
\hat{\infty} \\
\infty\end{array}$ & $\begin{array}{l}\overrightarrow{7} \\
\dot{f}\end{array}$ & $\begin{array}{c}\text { d } \\
\substack{1 \\
m}\end{array}$ & 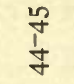 & 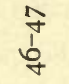 & $\begin{array}{l}g \\
\substack{1 \\
q}\end{array}$ \\
\hline \multicolumn{9}{|l|}{$\begin{array}{l}\text { Number of cases : } \\
\text { right hand } . . . . .\end{array}$} \\
\hline $\begin{array}{l}\text { left hand } \ldots \ldots \ldots \ldots \\
\text { Per cent: }\end{array}$ & I5 & 9 & I I & I & 4 & $\cdots \cdot$ & $\cdots \cdot$ & ... \\
\hline right hand...$\ldots$. & 16.5 & 8.7 & 3.5 & 7.8 & 4.3 & 5.2 & 1.7 & 0.9 \\
\hline left hand .......... & 13.0 & 7.8 & 9.6 & 0.9 & 3.5 & $\ldots$ & $\ldots$ & $\cdots$ \\
\hline
\end{tabular}

${ }^{1}$ Maximum, in kilograms.

KHARGA OASIS, MEN: TESTS OF MUSCULAR FORCE: TRACTION 1

Number of observations: III.

Average: $22.3 \mathrm{~kg}$. (Ist $50: 21.3 ; 2 \mathrm{~d} 50: 22.6$. )

Median: 2I. Mode: 25.

Minimum: 12. Maximum: 37 .

Table of frequencies:

\begin{tabular}{|c|c|c|c|c|c|c|c|c|c|c|c|c|c|}
\hline & $\underset{\mathfrak{s}}{\mathfrak{I}}$ & 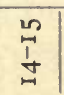 & $\hat{\mathfrak{t}}$ & $\stackrel{a}{1}$ & ָ̃ & ָู & $\frac{4}{\mathfrak{n}}$ & ते & $\mid \begin{array}{c}\text { i } \\
\text { i } \\
\infty \\
\text { d }\end{array}$ & $\ddot{\tilde{b}}$ & $\begin{array}{l}\tilde{1} \\
\text { ñ }\end{array}$ & m̃ & ई̂े \\
\hline $\begin{array}{l}\text { Number of cases. } \\
\text { Per cent......... }\end{array}$ & $\begin{array}{c}2 \\
1.8\end{array}$ & $\begin{array}{l}10 \\
9.0\end{array}$ & $\begin{array}{c}14 \\
12.6\end{array}$ & $\mid \begin{array}{c}12 \\
10.8\end{array}$ & $\begin{array}{c}17 \\
15.3\end{array}$ & $\begin{array}{l}10 \\
9.0\end{array}$ & $\begin{array}{c}16 \\
14.4\end{array}$ & $\begin{array}{c}13 \\
11.7\end{array}$ & $\begin{array}{c}3 \\
2.7\end{array}$ & $\begin{array}{c}7 \\
6.3\end{array}$ & $\begin{array}{c}5 \\
4.5\end{array}$ & $\begin{array}{c}1 \\
0.9\end{array}$ & \\
\hline
\end{tabular}

${ }^{1}$ In kilograms.

The above data show that the Kharga natives are on the average a rather weak lot. The pressure force, with the same instrument and method, averages in white males in the right hand about $45 \mathrm{~kg}$., in the left $37 \mathrm{~kg}$., and the traction $27 \mathrm{~kg}$. Fifteen healthy and as far as 
could be determined full-blood American negro men gave the writer, with the same instrument, as the mean pressure in the right hand 41.5 , in the left hand $38.6 \mathrm{~kg}$., and traction of $30 \mathrm{~kg}$. In the Indian, ${ }^{1}$ in general, the corresponding figures are about 40,34, and $25 \mathrm{~kg}$. At Kharga they are, as seen above, 34, 3I, and $22 \mathrm{~kg}$.

The debility of the Kharga men is in all probability the effect, in the main, of poor and scant nutrition. The Valley fellaheen impress one as somewhat better off in this respect, and also as somewhat stronger, yet even they, so far as observed, do not approach in muscular strength the whites or the negro of similar vocations.

The average difference between the pressure force of the right and that of the left hand is less marked in the Kharga natives than that in the white and also the Indian, showing that the right hand is not only absolutely but also relatively weaker in those of the Oasis.

The age differences in strength are quite pronounced and follow what is probably a general rule, showing a gradual decline after 40 years of age. The maximum mean of muscular power is reached between 30 and 40 , or more properly between 25 and 35 years, which appears also to be most frequently the case in the whites as well as in the American Indians.

KHARGA OASIS, MEN: RESULTS OF TESTS OF MUSCULAR STRENGTH OF THE HANDS (PRESSURE) AND ARMS (TRACTION), ACCORDING TO AGE 2

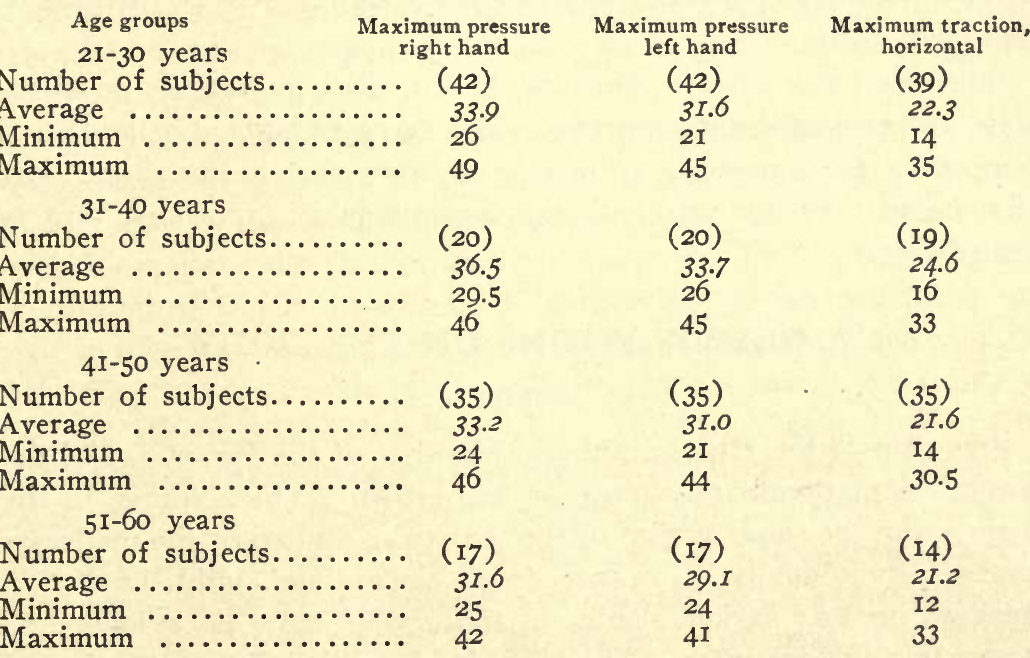

${ }^{1}$ Details in writer's "Physiological and Medical Observations," etc., p. I43 et seq. The tests on the Indians were equally made by the same method and instrument.

${ }^{2}$ All records in kilograms. 
As to the relation of strength with stature, the ${ }_{5} 5$ healthy tallest Kharga men gave the average right hand pressure of $36.5 \mathrm{~kg}$., the 20 shortest ones $33.9 \mathrm{~kg}$, a decided advantage for those of higher stature. Everything indicates that those of the lowest statures at the Oasis are also those who present a greater general weakness, as well as subnormal metabolism, while with those of the highest statures these conditions are reversed. From this it seems safe to conclude that short and tall statures, in this locality at least, are not pure racial characteristics, but that they are largely due to the state of health and nourishment of the individual during growth, and hence to environment; and it can be assumed that when the economic and hygienic conditions of the Oasis shall ameliorate, as they are bound to do with the advance of civilization, the population will respond to an important degree by better physical development.

\section{RÉSUMÉ OF THE PRINCIPAL PHYSIOLOGICAL OBSERVATIONS}

The Kharga Oasis men show on the average, in comparison with the European whites, a perceptibly faster pulse; a slightly faster respiration; a perceptibly lower temperature; and decidedly lower muscular power.

The differences in these functions according to age and stature follow in general the same laws as among whites, American Indians, and other races.

The principal defects observed in the Kharga natives in these tests are evidently not anthropological characteristics, but local and temporary phenomena, attributable in the main to the immediate environment, particularly nutrition, and are in all probability largely remediable.

\section{OBSERVATIONS ON THE BODY}

\section{COLOR}

The skin of the Kharga natives, like that of the Egyptians of the Valley, is predominantly more or less brown. The color is, in the main, quite the same as that of the American Indian of the moderate zones. Individually it ranges from tawny and light brown to medium brown; darker shades in those who show no evidence of negro mixture are rare. The records show that lighter shades of yellow-brown or brown existed in 18 per cent; moderate brown in $8 \mathrm{I}$ per cent, and dark brown in but I per cent of the men examined. The secondary shadings of different parts of the body are, so far as 
observed, in no way particular, and the exposed parts, as elsewhere, are generally darker than those habitually covered. On the head, which is always covered, the skin is occasionally nearly as white as in brunet Europeans. The color of the eyes is generally medium to dark brown.

\section{HAIR}

The hair is as a rule black, and in those who are not mixed with the negro it is generally straight or approaching straight. It runs thus in 88 per cent of the men examined; in 6 per cent it was black and distinctly wavy; in 5 per cent black with a tendency to curl; and in I individual it was dark brown and straight. In women, where the hair is much longer (many of the men clip the hair short or even shave the head), it is, so far as could be observed, generally more or less wavy, with occasional tendency to curl ; in children it is straight, wavy or slightly curly. The Coptic mummies at El Baguat showed in general hair that was black and straight to moderately wavy. A decidedly curly hair in Kharga natives was as a rule found associated with thick lips and other negro features. It appears, in fact, as if the tendency to curly hair was one of the most lasting effects in the progeny of one-time negro admixture.

Grey hair, to any appreciable extent, was only seldom noticed before the 4oth year, and occasionally men of 48-50 years of age showed hair that was nearly all black. At 55 and above greyness was as a rule advanced.

As to beard, conditions were found as follows: In 94 per cent of the men examined the color of the hair on the face was black, while in 6 per cent it was dark but not quite black; and in a number of additional cases the moustache showed a trace lighter than the rest of the beard which was black. The quantity of the moustache was fair in 8, moderate in 49 and scanty in 43 per cent of the individuals; the chin beard was fair in quantity in 5 , moderate in 30 , scanty in 49 and absent (naturally) or nearly so in 16 per cent of the cases. The total absence of beard was noticed however, with a very few exceptions, only in those below 30 years of age. In form the hair of the face, when longer, shows generally more or less tendency towards waviness. This is especially true of the chin beard and of the more distal parts of both beard and moustache. Greyness of moustache was found to begin somewhat later and to be generally less advanced than that of the hair of the scalp; that of the chin beard was seen to begin about the same time as that of the head. 
No instance was found of a well developed baldness of the top of the head; in 26 of the men ( 17 per cent) there was more or less of a loss in the front, so that the original height of the forehead could not be determined. In no case, however, did this calvitia reach near to bregma.

Abnormal hairiness of the body was not noticed in any instance.

\section{FEATURES OF THE HEAD}

The head was observed to be generally of moderate size. No instance of either artificial or pathological deformation came to notice. In shape it is generally oblong and with either an elliptical, somewhat ovoid, or pentagonal outline of the norma superior. On the whole the head of the average Kharga native is much like that of the ordinary non-negroid Egyptian, and lacks all distinctive negro features.

The forehead in 86 per cent of the cases was found comparable with the average form in the whites; in 5 per cent it was high (naturally), in 6 low and in 2 per cent sloping.

The supraorbital ridges were large in I case; they were about as developed as in average white males in 27 per cent, of a submedium to very small development in $7 \mathrm{I}$ per cent, and wholly absent in one of those examined.

The occiput was in no case especially protruding, the external occipital protuberance or ridges in no case pronounced.

The ears were found to be generally fairly well formed, lying normally near the head or but moderately abstanding, and both in size and shape quite like those of whites, but unlike the characteristic ear of the negro, ${ }^{1}$ which only appeared occasionally in the mixed-bloods. The separation of the lobule is occasionally more or less deficient.

\section{FACIAL FEATURES}

The outline of the face is generally near elliptical or ovoid, with the lower portion occasionally angular.

The eyes, or more properly eye-slits, were in 97 per cent of the examined horizontal or nearly so, as in Europeans; in I case they were perceptibly oblique with the distal canthi higher, and in 2 cases they were oblique with the distal canthi lower than the proximal.

The nasion depression was but slight in 12 , moderate or medium

${ }^{1}$ See Hrdlička, A. : Anthropological Investigations on One Thousand White and Colored Children, etc. $8^{\circ}$, New York, 1899. 
(as compared with whites) in 86 , and pronounced in 2 per cent of the cases.

The nose is generally not of great size or prominence. The bridge was found straight in 42 , slightly convex in $4 \mathrm{I}$, convex in 3 , concavo-convex in Io and slightly concave in 4 per cent. It may be said then to be in general straight or slightly convex.

The nasal septum is prevalently horizontal or somewhat inclined downward. It was horizontal in 62 per cent, slightly inclined downwards (distal end lower than proximal) in 18 , very perceptibly inclined downward in 9, and slightly inclined upward (distal part higher than proximal with head in natural position) in II per cent of the cases.

The alæ of the nose are seldom broad and in the unmixed never show the characteristics of those in the negro.

The lips were found to be of about medium size, or not exceeding the ordinary dimensions of lips in white males, in 83 per cent of the men, while they were perceptibly to moderately thicker in 17 per cent.

Prognathism on the whole is somewhat more marked than in the average Europeans, but in a pronounced form is rare; the conditions in this respect were about as the mean in white men, or but slightly more marked, in 78 per cent, moderately more pronounced in 19 per cent, and decidedly more pronounced than in average whites in 3 per cent of those examined.

The chin was in 85 per cent of the cases of medium proportions and form, compared with the whites; in I 3 per cent of the individuals it was more or less angular or "square," in I man it was unusually pointed and in I unusually long. The angles of the lower jaw showed in 84 per cent of the individuals medium development, in 14 per cent they were above average in size or prominence, and in 2 per cent they were perceptibly below such average.

The malar regions showed about medium size (as compared with whites) and moderate prominence in 78 per cent, were sub-medium in both these features in 4 per cent and above medium in 18 per cent of the cases.

Among the 150 men who were specially examined, there was no one with any marked asymmetry of face or with any anomalies of importance.

The neck is usually of medium development and quite cylindrical; in the younger men it is frequently rather high. 


\section{BODY AND LIMBS}

So far as could be determined without undressing the subjects, 96 per cent of them presented a body of medium development and without marked abnormalities; none were obese, but 4 per cent were unusually thin, though not decrepit. No special differences were observed in the various parts of the body from the normal or most common type in whites.

The hands and feet. are generally fairly well formed and not large. No anomaly of fingers came to notice. The fingers and toes are not long. The toes were normal in 95 per cent, in 5 per cent of the individuals they presented some peculiarities. ${ }^{1}$ They were only very rarely seen markedly separated, as they are frequently in the Indian. In those who work and go bare-footed the toes are generally thickened.

\section{CONCLUDING REMARKS ON NON-INSTRUMENTAL OBSERVATIONS}

The features of the Kharga natives are in general much like those of the fellaheen of the Valley who do not show an admixture with the negro. Nevertheless the physiognomy of the Oasis men seems somewhat distinctive. They could be easily told from the often finely shaped Berberine or Barabra of upper Egypt, and the student comes to believe that he could recognize them even from the natives of the neighboring parts of the valley; but the differences would not be easy to define. The Egyptians of the Valley, however, present a larger number of individuals of a decidedly semitic type of face. Beyond the Valley, the physiognomy of the Oasis people is close to that of the Arab and the north African non-negro native in general.

The various characteristics of the head, face, and body, barring the color, when closely scrutinized, are found to be closely related to those of the white race and to have nothing in common with what is distinctive of the negro.

\section{MEASUREMENTS}

STATURE

The height of the Kharga Oasis men is unusually small, averaging barely $163.8 \mathrm{~cm}$. ( $5 \mathrm{ft} .4^{\mathrm{T}} / 2 \mathrm{in}$.). The exact conditions were as follows :

${ }^{1}$ The principal anomalies were as follows: (a) The 4 th and 5 th left toes, especially the latter, turned outward and downward; (b) the 5 th left toe is diminutive; and (c) the great toe shows a small toe-like (nailless) growth on its inner side and near the end. 
KHARGA OASIS, MEN: STATURE

Number of individuals measured: I50.

Average : $163.8 \mathrm{~cm}^{1}{ }^{2}$ (Ist $50: 164.3 ; 2 \mathrm{~d} 50: 162.3 ; 3 \mathrm{~d} 50: 164.9 \mathrm{~cm}$.)

Median I64.0 cm. Modes: I6I.5 (I6I-I62) and I68 (I67-I68) $\mathrm{cm}$.

Minimum: $I 50.6 \mathrm{~cm}$. Maximum: $I 74.6 \mathrm{~cm}$.

Table of frequencies:

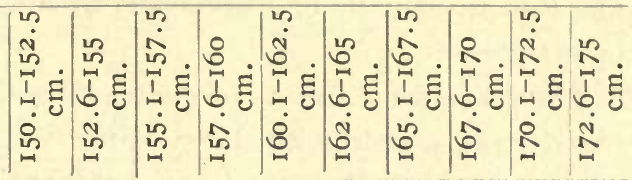

\begin{tabular}{ll|l|l|l|l|l|l|l|l|l} 
Number of cases.............. & 3 & 2 & 9 & 23 & 24 & 25 & 30 & 21 & 8 & 5
\end{tabular} $\begin{array}{lllllllllll}\text { Per cent....................... } 2.0 & 1.3 & 6.0 & 15.3 & 16.0 & 16.7 & 20.0 & 14.0 & 5.3 & 3.3\end{array}$

${ }^{1}$ Probable error $= \pm 0.269$; standard deviation, $\sigma,=4.89$, \pm 0.190 ; coefficient of variability, $C,=2.987, \pm 0.116$.

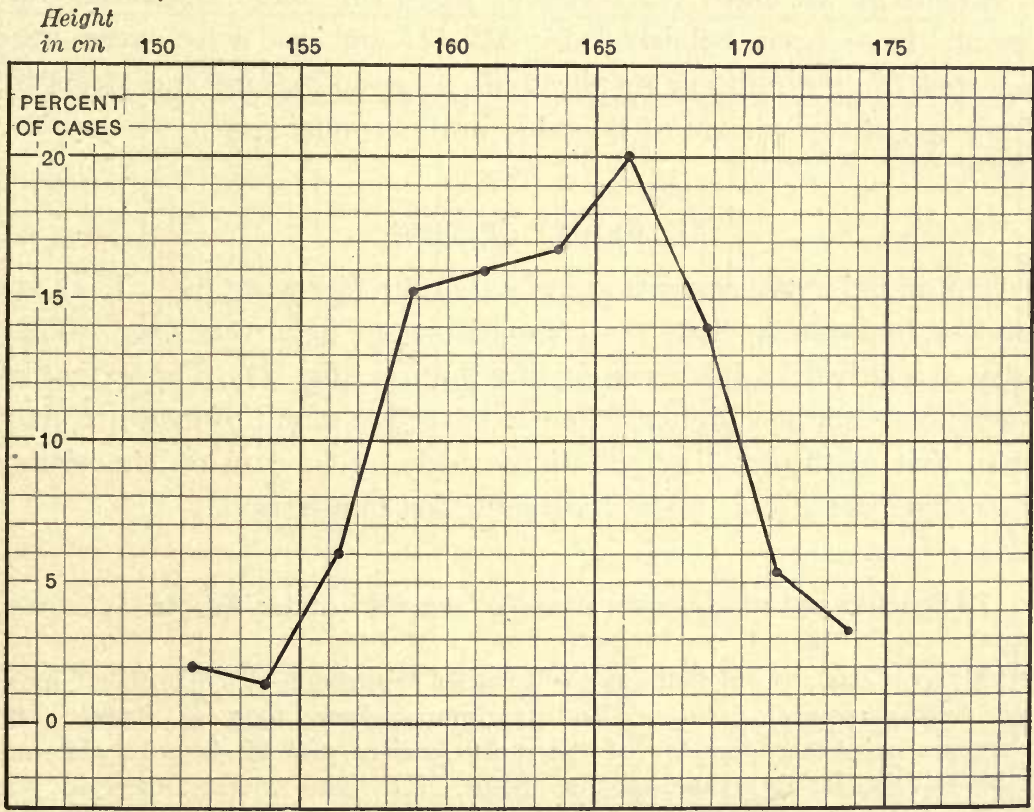

FIG. 2.-Curve showing the distribution of statures among I50 adult males of the Kharga Oasis.

The range of variation extends over $24 \mathrm{~cm}$., or \pm 0.073 per centimeter of the average, which can not be regarded as excessive. The distribution of the statures, however (fig. 2), is somewhat peculiar. If considered centimeter by centimeter, it gives two separate modes well apart. These conditions are probably not without 
significance, but to determine their exact bearing is difficult. They may be anthropological in nature, due to admixture of two or more elements outside of the negro, or they may be physiological, connected especially with the prevalent defective nutrition in the Oasis. Perhaps they are the complex result of both these factors. Problems like this can usually be solved only by long extended and comparative investigations.

There are some means of contrasting the stature measurements of the Kharga people with those of the Valley Egyptians. In 1904 E. Chantre published a work on anthropological research in Egypt ${ }^{1}$ and the following male statures are recorded: 127 Copts- $166.0 \mathrm{~cm}$. ; 9 I Fellaheen-I68.4 cm.; I34 Bedouins-I67.8 cm.; and 223 Bedjah (Ababdeh, Barabra, Bichariet) $-167.6 \mathrm{~cm}$. All these means are very perceptibly higher than those of the Kharga natives. Other measurements on an extensive series of Egyptians and Soudanese conscripts have been published by Myers, ${ }^{2}$ but as these were men selected for the military on the basis of good stature and strength, their height records are of no value in this connection.

\section{HEIGHT SITTING}

The actual measurements are given in the following list. They are of less importance than the comparisons to be given later. They give a relatively solid curve of distribution (fig. 3 ). The extent of variation is slightly higher, when compared to a unit of measurement, than that of the total height of the body. ${ }^{8}$ No data on the Valley Egyptians are in this respect available for comparison.

\footnotetext{
${ }^{2}$ Recherches anthropologiques dans l'Afrique orientale: Egypte. $4^{\circ}$, Lyon, I904.

${ }^{2}$ Myers, Chas.: Contributions to Egyptian Anthropology: Tatuing. Journal Anthropological Institute, Vol. 33, January-June, 1903, pp. 82-89. The Comparative Anthropometry of the most Ancient and Modern Inhabitants. Ibid. Vol. 35, January-June, 1905, pp. 80-91. III. The Anthropometry of the Modern Mahommedans; IV. The Comparison of the Mahommedans with the Copts and the "Mixed" Group. Ibid. Vol. 36, July-December, I906, pp. 237-271. Contributions to Egyptian Anthropology. Ibid. Vol. 28, JanuaryJune, I908, pp. 99-147.

${ }^{3}$ Variability per centimeter: stature \pm 0.073 ; height sitting $\pm 0.09 r$.
} 


\section{KHARGA OASIS, MEN: HEIGHT SITTING}

Number of individuals measured: $I 50$.

Average $84.0 \mathrm{~cm}^{1}{ }^{1}$ (Ist $50: 84.7 \mathrm{~cm}$; 2d $50: 82.7 \mathrm{~cm}$.; 3d $50: 84.5 \mathrm{~cm}$.)

Median : $84 . I \mathrm{~cm}$. Modes : $84.0(83.1-85.0) \mathrm{cm}$; $86.5(86.1-87.0) \mathrm{cm}$.

Minimum: $75.1 \mathrm{~cm}$. Maximum: $90.4 \mathrm{~cm}$.

Table of frequencies :

\begin{tabular}{|c|c|c|c|c|c|c|c|c|}
\hline & 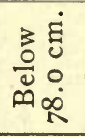 & 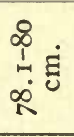 & $\begin{array}{l}\infty \\
1 \\
\stackrel{\infty}{\infty} \\
\stackrel{\infty}{\circ}\end{array}$ & 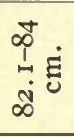 & 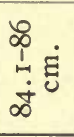 & 离 & ${ }_{\infty}^{8}$ & 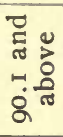 \\
\hline $\begin{array}{l}\text { Number of cases........ } \\
\text { Per cent } . . . \ldots \ldots \ldots\end{array}$ & $\begin{array}{c}2 \\
1.3\end{array}$ & $\begin{array}{l}\text { II } \\
7.3\end{array}$ & $\begin{array}{c}28 \\
18.7\end{array}$ & 22.0 & $\begin{array}{l}35 \\
23.3\end{array}$ & $\begin{array}{l}3 \mathrm{I} \\
20.7\end{array}$ & $6^{9} .0$ & ${ }_{0.7}^{I}$ \\
\hline
\end{tabular}

${ }^{1}$ Probable error \pm 0.155 ; standard deviation, $\sigma,=2.820$, \pm 0.1 Io; coefficient of variability, $C,=3.357, \pm 0.131$.

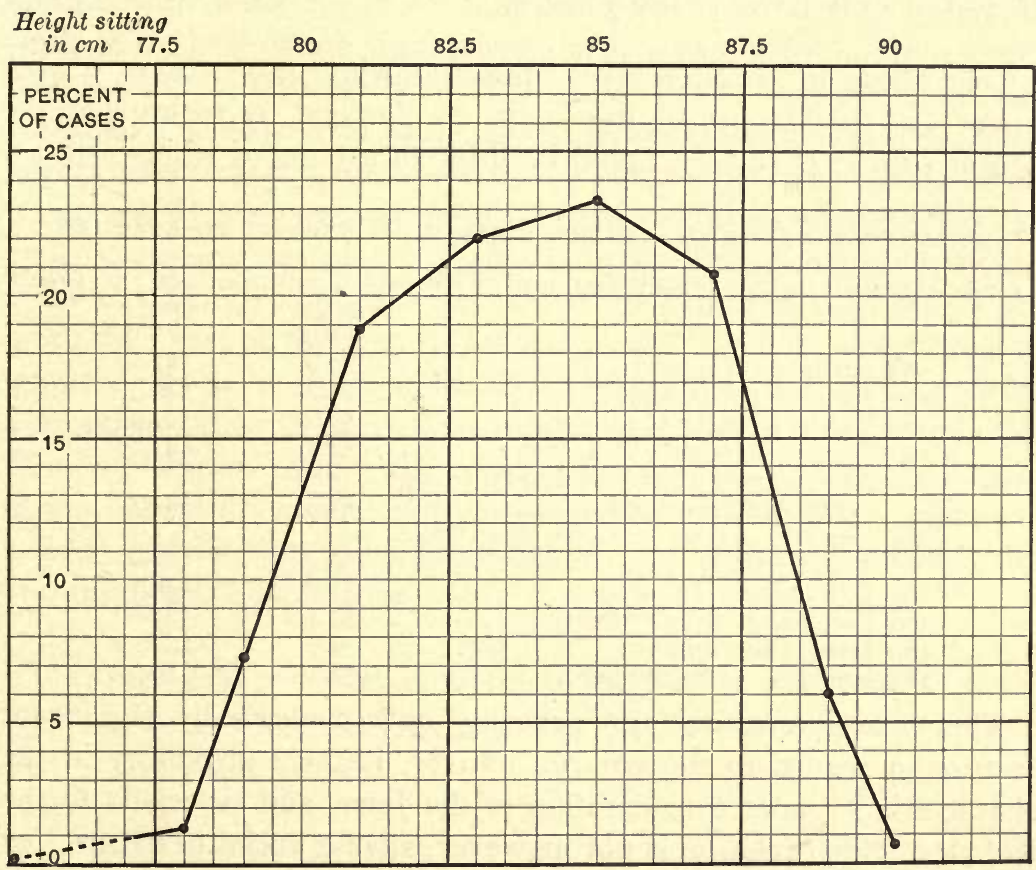

FIG. 3.-Curve showing the distribution of height above ischia (height sitting) among I50 adult males of the Kharga Oasis.

The relation of the length of that portion of the body above (or that below) the lowest level of the ischia to total stature is a feature of considerable anthropological interest. The Kharga natives show in this respect the conditions given in the next table. 
KHARGA OASIS, MEN: PERCENTAL RELATION OF HEIGHT SITTING, TO HEIGHT STANDING

Number of individuals: 150 .

Average: 5 I.26. ${ }^{1} \quad($ Sub ischia $=48.74$.

Median : 5 I.5. Mode : 5 I.5.

Minimum: 47.3. Maximum: 54.3.

Table of frequencies:

\begin{tabular}{|c|c|c|c|c|c|c|c|c|}
\hline & 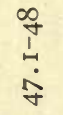 & $\begin{array}{c}\stackrel{9}{T} \\
\stackrel{1}{-1} \\
\stackrel{\infty}{+}\end{array}$ & $\begin{array}{l}\stackrel{0}{1} \\
\stackrel{1}{-1} \\
\dot{\sigma}\end{array}$ & $\begin{array}{l}\text { 로 } \\
1 \\
\stackrel{1}{0} \\
\text { in }\end{array}$ & 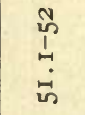 & 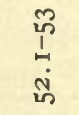 & 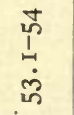 & 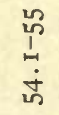 \\
\hline $\begin{array}{l}\text { Number of cases........ } \\
\text { Per cent............... }\end{array}$ & I 0.7 & $\begin{array}{c}8 \\
5.3\end{array}$ & ${ }^{9} .0$ & $\begin{array}{c}40 \\
26.7\end{array}$ & $\begin{array}{c}51 \\
34.0\end{array}$ & $\begin{array}{c}30 \\
20.0\end{array}$ & $\begin{array}{l}\text { I0 } \\
6.7\end{array}$ & I \\
\hline
\end{tabular}

${ }^{1}$ Probable error $= \pm 0.07 \mathrm{I}$; standard deviation, $\sigma,=\mathrm{I} .28 \mathrm{I}, \pm 0.050 ; \mathrm{co}-$ efficient of variability, $C,=2.499, \pm 0.097$

According to older sources, the following proportions of the upper and lower part of the body, as obtained by measuring the height sitting, have been found in different groups of whites, etc. :

PERCENTAL VALUE OF HEIGHT SITTING, IN REGARD TO STATURE (After different authors, from Topinard, Éléments d'Anthrop. gén., p. Io7o.) ${ }^{1}$

\begin{tabular}{|c|c|}
\hline & $\begin{array}{l}\text { Height } \\
\text { sitting }\end{array}$ \\
\hline 88 Sards (d'Hercourt) & 54.9 \\
\hline IOO Esthonians (Grube). ..... & 53.7 \\
\hline Ioo Keltic French (Collignon) ... & 52.6 \\
\hline Ioo Cymric French (Collignon) $\ldots . \ldots .$. & 52.2 \\
\hline $\begin{array}{l}329 \text { Americans (white) of } 21 \text { yrs. of age } \\
\text { (B. A. A. S. I879) } \ldots \ldots \ldots \ldots \ldots \ldots\end{array}$ & 52.7 \\
\hline 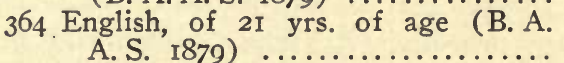 & \\
\hline 60 Lithuanians (Waeber). & $\begin{array}{l}52.4 \\
51.9\end{array}$ \\
\hline Ioo Livonians (Waldhauer) .... & 51.4 \\
\hline roo Jews (Blechmann) $\ldots \ldots \ldots \ldots \ldots$ & 5 I. 5 \\
\hline I84 Kabyles (Prengruber) $\ldots . \ldots \ldots$. & 5 I.4 \\
\hline
\end{tabular}

The most interesting and probably anthropologically significant feature in regard to the Kharga natives, is their proximity in the characteristic under consideration to the Jews, and especially to the Kabyles. Such relation is not, however, always racial in nature, for it may be merely a like result of similar environmental agencies, particularly poor nutrition.

Among the Indians, the typically dolichocephalic Pima gave the writer, for the height above ischia, 52.9 per cent; for that below the

${ }^{1}$ Compare also the results obtained on the dead by W. Pfitzner, Socialanthropologische Studien, Zeitschrift f. Morphologie and Anthropologie, Vol I, I899 p. 325 et seq.; Vol. 3, I90r, p. 485 et seq. 
ischia 47.I per cent of the total height; while among the typically brachycephalic Apache these proportions were respectively 53.2 and 46.8 per cent. ${ }^{1}$ In twenty apparently full blood male American negroes, measured by the writer, the same proportions were respectively $5^{\text {I. }} 4$ and 48.6 per cent.

The range of variation in the relative proportions of the height above and that below the ischia in the Kharga natives is remarkable. Each of these proportions is evidently influenced by numerous factors which do not act with equal effect on the other.

A research into the influences capable of modifying these proportions was possible in one important direction: the effects of the lowest and the highest statures. It has been shown already that the lowest statures, where not due to senility, stand often in close connection with weaker muscles and prolonged general poor nutrition, while in the case of the highest statures, the case is often the reverse. And the lowest statures, as will be shown in the next table, are also frequently accompanied with a subaverage relative length of the lower limbs, whereas in the tallest individuals the length infra ischia is perceptibly above the average. These conditions suggest that the main causative agencies of low statures, and probably above all chronic poor nutrition, affect adversely the length of the lower limbs more than that of the rest of the body, while favorable conditions of growth, especially, in all probability, good nutrition, cause in general a proportionately greater development in length of the lower limbs. The body supra ischia is the more stable portion, as regards length, of the human organism. There are indications that these conditions are not restricted to the Kharga natives, but will find a much wider anthropological application.

1 "Physiological and Medical Observations, etc.," p. II2 et seq. 
KHARGA OASIS, MEN: HEIGHT AND HEIGHT SITTING IN THE SHORTEST AND TALLEST INDIVIDUALS

\begin{tabular}{|c|c|c|c|c|c|c|c|}
\hline \multicolumn{4}{|c|}{ Stature $157.5 \mathrm{~cm}$. and less } & \multicolumn{4}{|c|}{ Stature $170 \mathrm{~cm}$, and more. } \\
\hline Stature & $\begin{array}{l}\text { Height sit- } \\
\text { ting }\end{array}$ & $\begin{array}{l}\text { Percental } \\
\text { relation of } \\
\text { height sit- } \\
\text { ting to } \\
\text { stature }\end{array}$ & $\begin{array}{l}\text { Percental } \\
\text { relation of } \\
\text { the parts } \\
\text { infraischia } \\
\text { to stature }\end{array}$ & Stature & $\underset{\text { ting }}{\text { Height sit- }}$ & $\begin{array}{l}\text { Percental } \\
\text { relation of } \\
\text { height sit- } \\
\text { ting to } \\
\text { stature }\end{array}$ & $\begin{array}{l}\text { Percental } \\
\text { relation of } \\
\text { the parts } \\
\text { infraischia } \\
\text { to stature }\end{array}$ \\
\hline${ }_{\text {I } 50.6}^{\mathrm{cm} .}$ & 79.8 & 53.0 & 47.0 & $\begin{array}{l}\mathrm{cm} . \\
170.5\end{array}$ & 85.6 & 50.2 & 40.8 \\
\hline 152.3 & 80.4 & 52.8 & 47.2 & 170.7 & 89.5 & 52.4 & 47.6 \\
\hline I 52.3 & 80.3 & 52.7 & $47 \cdot 3$ & I 71.1 & 88.5 & $5 I .7$ & 48.3 \\
\hline I 53.6 & 81.7 & 53.2 & 46.8 & 171.3 & 87.4 & 51.0 & 49.0 \\
\hline I 54.5 & $8 \mathrm{I} .0$ & 52.4 & 47.6 & 172.2 & 87.6 & 50.9 & $49: I$ \\
\hline I 55.2 & $8 \mathrm{I} .2$ & 52.3 & 47.7 & 172.4 & 84.8 & 49.2 & 50.8 \\
\hline I 55.7 & 81.4 & 52.3 & 47.7 & 172.4 & 87.1 & 50.5 & 49.5 \\
\hline 155.7 & $75 . \mathrm{I}$ & 48.2 & 51.8 & 172.5 & 84.8 & 49.2 & 50.8 \\
\hline I 55.7 & 78.6 & 50.5 & 49.5 & 172.7 & 88.3 & $5 I . I$ & 48.9 \\
\hline I 55.9 & 79.9 & $5 I .2$ & 48.8 & 172.7 & 88.3 & $5 I . I$ & 48.9 \\
\hline I 56.0 & 80.1 & $5 I .3$ & 48.7 & 173.8 & 85.5 & 49.2 & 50.8 \\
\hline I 56.3 & 80.4 & $5 I .4$ & 48.6 & I 74.5 & 90.4 & 51.8 & 48.2 \\
\hline I 56.5 & 79.0 & 50.5 & 49.5 & 174.6 & 85.8 & $49 . I$ & 50.9 \\
\hline 157.5 & 82.1 & $52 . I$ & 47.9 & & & & \\
\hline \multicolumn{4}{|c|}{ Averages ( 14 individuals): } & \multicolumn{4}{|c|}{ Averages ( 13 individuals): } \\
\hline 154.8 & 80.1 & 51.7 & 48.3 & 172.4 & 87.4 & 50.6 & 49.4 \\
\hline
\end{tabular}

As to the effect of age on the relative proportion of the upper and lower parts of the body, the Kharga series shows nothing definite; but it includes no really senile individuals. It seems safe to assume that, due principally to the frequent greater bending of the spine in the aged, the average value of the height above ischia in relation to that below the ischia diminishes in advanced age. This principle is, of course, applicable to all groups of mankind, not merely the Egyptians.

\section{THE HEAD}

\section{Length of Head}

The maximum length of the head averages 18.9 centimeters, which is a fair dimension. Its range of variation extends over $28 \mathrm{~mm}$., equaling \pm 0.74 per each $\mathrm{cm}$. of the average, which is not excessive.

The curve of distribution of the measurement (fig. 4) is somewhat unusual. 
KHARGA OASIS, MEN: DIAMETER ANTERO-POSTERIOR OF MAXIMUM HEAD

Number of individuals measured: $150 .^{1}$

Average: $18.9 \mathrm{~cm}^{2}$ (Ist $50: 19.0 ; 2 \mathrm{~d} 50: 18.8 ; 3 \mathrm{~d} 50: 18.9 \mathrm{~cm}$. )

Median: $18.9 \mathrm{~cm}$. Mode: $19.0 \mathrm{~cm}$.

Minimum : $17.6 \mathrm{~cm}$. Maximum: $20.4 \mathrm{~cm}$.

Table of frequencies:

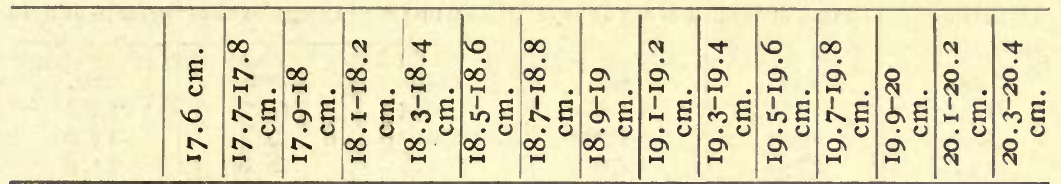

Number of

\begin{tabular}{c|c|c|c|c|c|c|c|c|c|c|c|c|c|c|c} 
cases.... & I & 3 & 3 & 8 & I0 & 22 & 22 & 30 & 22 & 9 & 9 & 4 & 5 & I & I
\end{tabular}

$\begin{array}{lllllllllllllllll}\text { Per cent... } & 0.7 & 2.0 & 2.0 & 5.3 & 6.7 & 14.7 & 14.720 .014 .7 & 6.0 & 6.0 & 2.7 & 3.3 & 0.7 & 0.7\end{array}$

${ }^{1}$ Includes no deformed or pathological heads; and the same applies to the other skull measurements.

2 Probable error $= \pm 0.028$; standard deviation, $\sigma$, $=0.5054, \pm 0.020$; coefficient of variability, $C,=2.674, \pm 0.104$.

\section{Breadth of Head}

The greatest breadth of the head gives the moderate mean of 14.4 $\mathrm{cm}$. It varies to the extent of $25 \mathrm{~mm}$., or 0.088 per each $\mathrm{cm}$. of the average, hence slightly more than the length; the curve of distribution, however (fig. 4), though quite shouldered, is unusually solid.

\section{KHARGA OASIS, MEN: DIAMETER LATERAL MAXIMUM OF HEAD}

Number of individuals measured: 150.

Average: $14.14 \mathrm{~cm}^{1}{ }^{1}$ (Ist $50: 14.14 ; 2 \mathrm{~d} 50: 14.06 ; 3 \mathrm{~d} 50: 14.22 \mathrm{~cm}$.)

Median: $14.2 \mathrm{~cm}$. Mode: $14.4 \mathrm{~cm}$.

Minimum: $12.8 \mathrm{~cm}$. Maximum: $15.3 \mathrm{~cm}$.

Table of frequencies:

\begin{tabular}{|c|c|c|c|c|c|c|c|c|c|c|c|c|c|}
\hline & 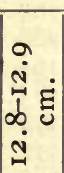 & $\begin{array}{l}\dot{E} \\
\ddot{\sim} \\
\ddot{\oplus} \\
\stackrel{\sim}{\sim}\end{array}$ & 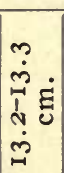 & $\begin{array}{l}\dot{n} \\
\dot{n} \\
\tilde{T} \\
\dot{1} \\
\dot{n} \\
\tilde{n}\end{array}$ & $\begin{array}{l}\hat{n} \\
\tilde{n} \\
\dot{b} \\
\dot{m} \\
\dot{m}\end{array}$ & 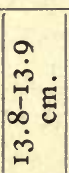 & 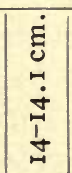 & 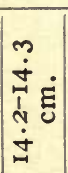 & 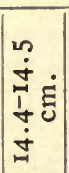 & 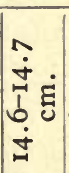 & 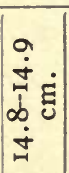 & 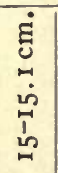 & 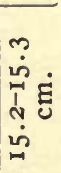 \\
\hline $\begin{array}{l}\text { Number of cases. } \\
\text { Per cent........ }\end{array}$ & $\begin{array}{l}\mathrm{I} \\
0.7\end{array}$ & 2.0 & $\begin{array}{c}2 \\
1.3\end{array}$ & $\begin{array}{l}7 \\
4.7\end{array}$ & $\begin{array}{l}\text { I3 } \\
8.7\end{array}$ & $\begin{array}{c}19 \\
12.7\end{array}$ & $\begin{array}{c}25 \\
16.7\end{array}$ & $\begin{array}{c}27 \\
18.0\end{array}$ & $\begin{array}{c}28 \\
18.7\end{array}$ & $\begin{array}{l}14 \\
9.3\end{array}$ & 3.3 & $2^{4} .7$ & $\begin{array}{c}2 \\
1.3\end{array}$ \\
\hline
\end{tabular}

${ }^{1}$ Probable error $= \pm 0.025$; standard deviation, $\sigma$, $=0.4507, \pm 0.018$; coefficient of variability, $C,=3.196, \pm 0.124$.

Both the length and the breadth of the head augment, as will be seen in the next table, with the height of the body, and they augment at nearly the same ratio. The latter fact indicates that it is in 
KHARGA OASIS, MEN: RELATION OF IENGTH AND BREADTH OF HEAD TO STATURE

Length and breadth of head in the lowest and highest statures

\begin{tabular}{|c|c|c|c|c|c|}
\hline \multicolumn{3}{|c|}{ I4 shortest individuals of the. series } & \multicolumn{3}{|c|}{${ }_{3}$ tallest individuals of the series } \\
\hline Stature & Length of head & Breadth of head & Stature & Length of head & Breadth of head \\
\hline$c m$ & $\mathrm{~cm}$. & $c m$ & $c m$ & $\mathrm{~cm}$. & $\mathrm{cm}$ \\
\hline I 50.6 & 18.5 & 13.9 & 170.5 & 19.2 & I3.I \\
\hline 152.3 & I8.0 & 13.35 & 170.7 & I 9.4 & 13.0 \\
\hline 152.3 & I8.9 & I 2.9 & I7I.I & I8.8 & I3. 8 \\
\hline I 53.6 & I8. 2 & 12.7 & I7I. 3 & I9.9 & I4. I 5 \\
\hline I 54.5 & I 8.5 & I 2.5 & 172.2 & I9.0 & 13.3 \\
\hline 155.2 & 19.2 & 13.7 & 172.4 & I8.6 & I 2.8 \\
\hline I 55.7 & 19.3 & 13.5 & 172.4 & 19.9 & 13.55 \\
\hline I 55.7 & 19.6 & 13.05 & I 72.5 & I8.4 & 13.55 \\
\hline I 55.7 & I9. 4 & 13.25 & 172.7 & 19.0 & 13.05 \\
\hline I 55.9 & 18.2 & 13.0 & 172.7 & I8. 9 & 13.4 \\
\hline I 56.0 & I8. 8 & 12.95 & 173.8 & 19.0 & 13.1 \\
\hline I 56.3 & I8. 2 & 13.0 & 174.5 & I8. 3 & 13.45 \\
\hline I 56.5 & 19.5 & I 3.2 & 174.6 & I8.7 & I3. 5 \\
\hline I 57.5 & 17.7 & 13.2 & & & \\
\hline
\end{tabular}

Averages :

\begin{tabular}{|c|c|c|c|c|c|}
\hline 154.8 & $\begin{array}{c}18.7 \\
(17 \cdot 7-19.6)\end{array}$ & $\begin{array}{c}13.16 \\
\left(12.5^{-13.9)}\right.\end{array}$ & 172.4 & $\begin{array}{c}19.0 \\
(18.3-19.9)\end{array}$ & $\begin{array}{c}13.37 \\
\text { (I2.8-I4.I5) }\end{array}$ \\
\hline
\end{tabular}

Stature and breadth of head corresponding to shortest and longest heads

\begin{tabular}{|c|c|c|c|c|c|}
\hline \multicolumn{3}{|c|}{ I5 shortest heads } & \multicolumn{3}{|c|}{ I5 longest heads } \\
\hline Length of head & Stature & Breadth of head & Length of head & Stature & Breadth of head \\
\hline $\begin{array}{l}c m . \\
17.6 \\
17.7 \\
17.7 \\
17.8 \\
18.0 \\
18.0 \\
18.0 \\
18.1 \\
18.1 \\
18.1 \\
18.2 \\
18.2 \\
18.2 \\
18.2 \\
18.2\end{array}$ & $\begin{array}{l}\mathrm{cm} . \\
162.0 \\
157.5 \\
169.4 \\
157.8 \\
163.0 \\
152.3 \\
163.7 \\
160.7 \\
160.8 \\
161.3 \\
164.7 \\
153.6 \\
155.9 \\
168.0 \\
156.3\end{array}$ & $\begin{array}{l}\mathrm{cm} . \\
13.0 \\
13.2 \\
12.85 \\
12.6 \\
12.9 \\
13.35 \\
12.5 \\
13.05 \\
13.1 \\
13.0 \\
13.55 \\
12.7 \\
13.0 \\
12.3 \\
13.0\end{array}$ & $\begin{array}{l}\mathrm{cm} . \\
19.6 \\
19.6 \\
19.6 \\
19.6 \\
19.7 \\
19.8 \\
19.8 \\
19.8 \\
19.9 \\
19.9 \\
20.0 \\
20.0 \\
20.0 \\
20.1 \\
20.4\end{array}$ & $\begin{array}{l}\mathrm{cm} . \\
\text { I } 55.7 \\
\text { I } 59.8 \\
\text { I68.8 } \\
\text { I64.7 } \\
\text { I65.0 } \\
168.3 \\
164.8 \\
\text { I65.8 } \\
172.4 \\
171.3 \\
\text { I63.3 } \\
\text { I69.4 } \\
\text { I66. I } \\
\text { I63.4 } \\
\text { I68.6 }\end{array}$ & $\begin{array}{l}\text { cm. } \\
\text { I3.05 } \\
\text { I3.3 } \\
\text { I3.15 } \\
\text { I3.3 } \\
\text { I3.3 } \\
\text { I } 4.1 \\
13.5 \\
13.4 \\
13.55 \\
\text { 14.15 } \\
\text { I3.55 } \\
\text { I3.7 } \\
\text { I3.4 } \\
\text { I3.05 } \\
\text { 13.4 }\end{array}$ \\
\hline \multicolumn{6}{|l|}{ Averages: } \\
\hline 18.0 & $\begin{array}{r}160.5 \\
\left(152.3^{-}\right. \\
169.4)\end{array}$ & $\begin{array}{c}12.9 \\
\left(12.3^{-13} \cdot 55\right)\end{array}$ & 19.85 & $\begin{array}{c}165.8 \\
(155.7- \\
172.4)\end{array}$ & $\begin{array}{r}13.64 \\
(13.05- \\
14.15)\end{array}$ \\
\hline
\end{tabular}


reality the size of the head and not its length or breadth that is directly correlated with the stature.

The augmentation in both measurements is not exactly proportionate to stature in all its grades, but lags behind as the stature increases, so that while in the shortest men the length and breadth of the head represent respectively I2.I and 8.5 per cent of the body height, in the tallest men they represent only II.O and 7.75 per cent of the same.

\section{Cephalic Index}

The cephalic index averages 74.83 , which characterizes the Kharga people as in general dolicho- and mesocephalic. The extremes extend on one side to hyperdolichocephaly while on the other they barely reach the beginning of brachycephaly, showing that there is but little tendency towards real broad-headedness. The range of variation, I 2.7 or \pm 0.085 per unit of the average, is not unusual. The curve of distribution (fig. 4) of the index, however, shows two pronounced and well separated points, which exceed considerably any effects of the mathematical probable error and which, considering the number of subjects involved, can not well be regarded as without significance. The tendency towards this double grouping is recognizable in the distribution curves of both the measurements the relation of which is expressed by the cephalic index, but in the latter the condition is especially clear. It is interesting to note that Myers $^{1}$ found a very much similar condition in the soldiers from several of the Egyptian provinces, but decided, not warrantably, it seems, that the two peaks of his polygons "were purely due to chance." The two peaks were located in all cases one at 73 and the other at 76-77, which agrees closely with the 72.5 and 75.5 peaks at Kharga.

The writer feels obliged to regard the principal grouping shown by the cephalic index curve or polygon at Kharga as not wholly accidental. It has very probably other causes. These may be racial, in which the condition would express a mixture of two ethnic elements, one more and one less dolichocephalic; or it may be pathological, using this term especially in its extension to various defective conditions that are liable to affect adversely the developments and growth of the organism. The problem is difficult of definite solution from the data at hand. The writer's impression is that in this case it is principally the anthropological factor that is accountable.

${ }^{1}$ Myers, C. S.: Contribution to Egyptian Anthropology; III. The Anthropometry of the Modern Mahommedans. Jour. Anthr. Inst. Vol. 36, 1906, p. 246 et seq. 


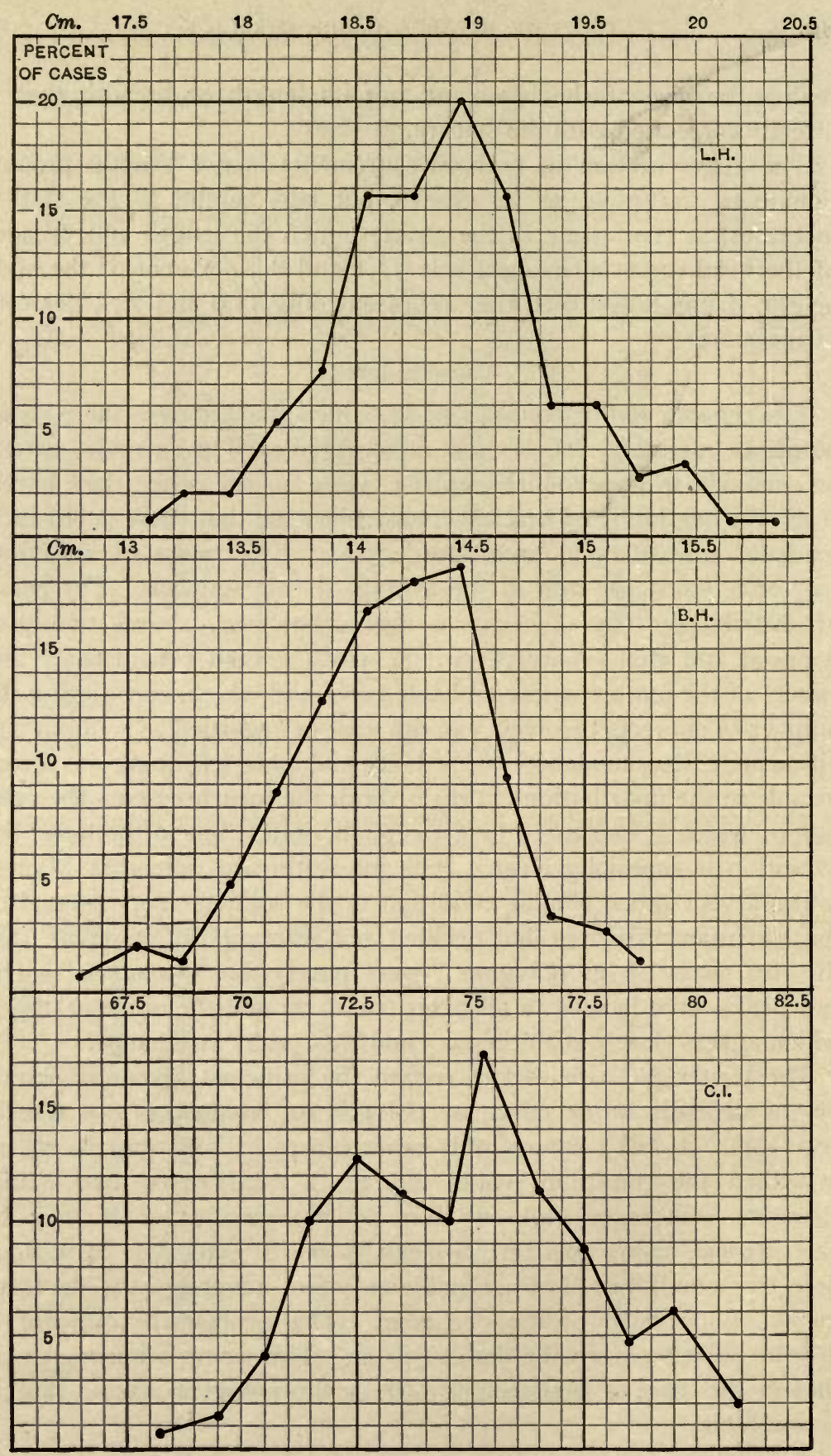

Fig. 4- - Curve showing the distribution of Length of Head (L. H.), Breadth of Head (B. H.) and Cephalic Index (C. I.), in I50 adult males of the Kharga Oasis. 


\section{KHARGA OASIS, MEN: CEPHALIC INDEX}

Number of individuals: 150.

Average cephalic index: $74.83^{1}$ (Ist $50: 74.5 ; 2 \mathrm{~d} 50: 74.8 ; 3 \mathrm{~d} 50: 75.2$. )

Median: 75.0. Modes: 72.5 (72.I-73) and 75.5 (75.I-76).

Minimum: 68.2. Maximum: 80.9.

Table of frequencies:

\begin{tabular}{|c|c|c|c|c|c|c|c|c|c|c|c|c|c|}
\hline & $\begin{array}{l}8 \\
1 \\
01 \\
8\end{array}$ & $\begin{array}{l}R \\
\frac{1}{1} \\
8 \\
8\end{array}$ & $\begin{array}{l}\mathbb{R} \\
\stackrel{1}{1} \\
\stackrel{R}{R}\end{array}$ & $\begin{array}{l}\stackrel{N}{i} \\
\stackrel{1}{N} \\
\stackrel{N}{n}\end{array}$ & $\begin{array}{l}n \\
i \\
\stackrel{N}{N}\end{array}$ & 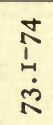 & 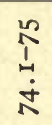 & $\begin{array}{l}R \\
1 \\
\\
\end{array}$ & $\begin{array}{l}\hat{1} \\
1 \\
\stackrel{1}{2} \\
\dot{R}\end{array}$ & 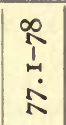 & $\begin{array}{c}\stackrel{a}{1} \\
1 \\
\stackrel{0}{0}\end{array}$ & 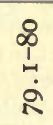 & $\begin{array}{l}\not{\phi} \\
\stackrel{0}{1} \\
\ddot{\infty}\end{array}$ \\
\hline $\begin{array}{l}\text { Number of cases. } \\
\text { Per cent .......... }\end{array}$ & $\begin{array}{l}\mathrm{I} \\
0.7\end{array}$ & $\begin{array}{c}2 \\
1.3\end{array}$ & $\begin{array}{c}6 \\
4.0\end{array}$ & I5 & I9 & 17 & I 5 & 26 & $\begin{array}{c}17 \\
11.3\end{array}$ & $\begin{array}{l}13 \\
8.7\end{array}$ & 4.7 & $\begin{array}{l}9 \\
6.0\end{array}$ & \\
\hline
\end{tabular}

${ }^{1}$ Probable error $= \pm 0.146$; standard deviation, $\sigma,=2.655, \pm 0.103$; coefficient of variability, $\bar{C}=3.544, \pm 0.138$.

The length of the head, the breadth of the head and the cephalic index of the men at Kharga show in general a close relation to similar determinations made by Chantre and Myers on the Valley Egyptians, as will be seen from the following comparison:

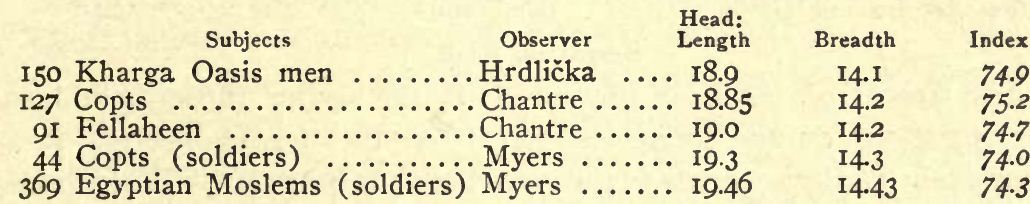

Myers' subjects, selected in recruiting for their tall stature, give naturally higher absolute values for the length and breadth measurements than the other series, but the index remains much the same as in the other groups; it varies, as seen, only to the extent of I.2 points in the five series recorded.

The cephalic index of the Kharga men agrees well with that of the Coptic mummies of the Oasis, and also, as will be shown below on one hand with that of the Arabs, and on the other with that of most of the Berbers and other non-negroid north-Africans. Of course it should be borne in mind that the similarity of the cephalic index is of anthropological value only when other important characteristics of the given groups are alike. Such agreement actually exists in the here adduced non-negroid peoples. 
MEAN CEPHALIC INDEX IN VARIOUS NORTH AFRICAN GROUPS

(Arranged from data given by Chantre. ${ }^{1}$ ) Males

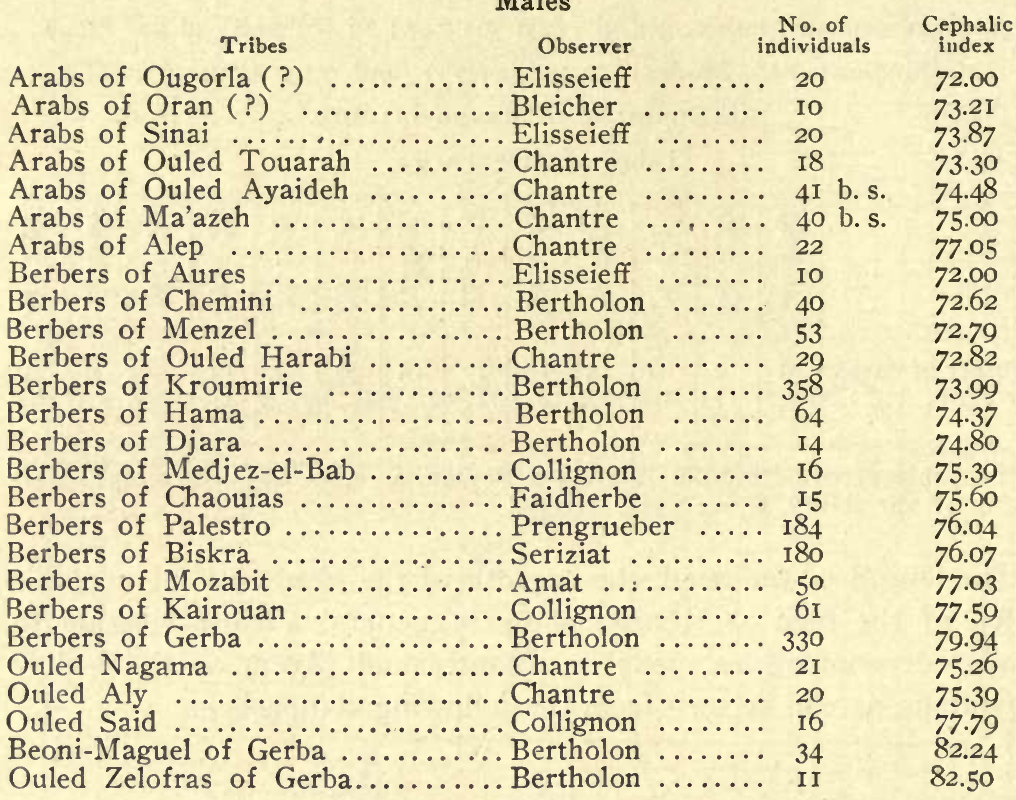

\section{Height of Head}

The height of the head measured by the writer throughout his investigations on the living, is that from the line connecting the floor of the auditory canals to the scalp over the bregma. The method relied upon and which gives results somewhat higher than those obtained by the means of Gray's radiometer, is given briefly in the footnote. $^{2}$ Regrettably both Chantre and Myers in their measurements on the Egyptians used other methods, and their results are not comparable with those here recorded.

\footnotetext{
${ }^{1}$ Recherches anthropologiques dans l'Afrique orientale: Egypte. $4^{\circ}$, Lyon I904.

${ }^{2}$ The measurement is obtained by a spreading and a sliding compass. The branches of a suitable compas d'épaisseur are introduced well into the auditory meati and allowed to rest on their floor. The expansion of the instrument is noted, with the scale held over the bregma region; the distance from the bregma region to the lower edge of the scale is measured by the rod of the compas glissière, and a simple arithmetical process gives the biauricular line-bregma height. With practice the measurement becomes easy, rapid, and at least as reliable as the measure of the same height by any other method. With due care, particularly as to the temperature of the instrument, the branches of the compass in the ears cause but very little discomfort. The writer has used this method now for many years with satisfactory results, and after testing the Gray's radiometer, must prefer it to that instrument.
} 
The conditions shown by this measurement in the Kharga men were as follows : ${ }^{1}$

KHARGA OASIS, MEN: HEIGHT OF HEAD

Number of individuals measured: I5O.

Average : $13.17 \mathrm{~cm}^{1}$ (Ist $50: 13.2 ; 2 \mathrm{~d} 50: 13.1$; $3 \mathrm{~d} 50: 13.2 \mathrm{~cm}$.)

Median: $13.2 \mathrm{~cm}$. Modes: 13.0 and $13.4 \mathrm{~cm}$.

Minimum: $I 2.3 \mathrm{~cm}$. Maximum: $I 4.1 \mathrm{~cm}$.

Table of frequencies:

\begin{tabular}{|c|c|c|c|c|c|c|c|c|c|c|}
\hline 2. & $\begin{array}{l}\dot{E} \\
\tilde{U} \\
\tilde{n} \\
\dot{\sim}\end{array}$ & 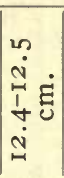 & 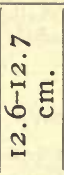 & $\begin{array}{l}a \\
\dot{\sim} \\
\tilde{\omega} \\
\infty \\
\dot{E} \\
\dot{\mathcal{E}} \\
\dot{v}\end{array}$ & 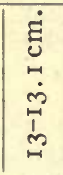 & 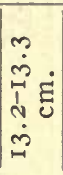 & 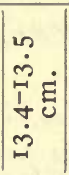 & 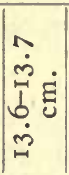 & 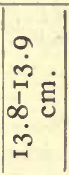 & 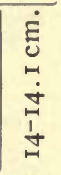 \\
\hline $\begin{array}{l}\text { Number of cases } \ldots \ldots \ldots \ldots \ldots \ldots \\
\text { Per cent..................... }\end{array}$ & 2.0 & 2.7 & $\begin{array}{l}14 \\
9.3\end{array}$ & $\begin{array}{c}19 \\
12.7\end{array}$ & $\begin{array}{c}31 \\
20.7\end{array}$ & $\begin{array}{c}32 \\
21.3\end{array}$ & $\begin{array}{c}31 \\
20.7\end{array}$ & $\begin{array}{c}8 \\
5.3\end{array}$ & $\begin{array}{c}6 \\
4.0\end{array}$ & $\stackrel{2}{1.3}$ \\
\hline
\end{tabular}

${ }^{1}$ Frobable error $= \pm 0.020$; standard deviation, $\sigma,=0.3646, \pm 0.014$; coefficient of variability, $C,=2.762, \pm 0.108$.

The average height of the head, based on the above measurements, namely $13.17 \mathrm{~cm}$., corresponds to a somewhat higher basion-bregma height on the skull and indicates that the cranium of the Kharga Oasis natives is relatively of moderate height.

The variation of this dimension extends to $18 \mathrm{~mm}$., which is \pm 0.069 for each $\mathrm{cm}$. of the mean measurement.

Several interesting features are revealed by the study of the relation of the height of the head to the form of the head, the height of the body, and the size of the head.

As shown in the following table, the relation between the height of the head and the cephalic index is quite insignificant. The average of the cephalic index in the lowest and the highest heads is very much alike. Among the lowest heads seven are dolichocephalic (below 75), while among those of the highest heads there are eight of that form.

It may then be concluded that in the Kharga men the head form as expressed by the cephalic index is not in any appreciable way dependent on, nor does it affect in any appreciable way, the height of the head.

The relation of stature to the height of the head is more evident. The series of lowest heads shows an association with notably smaller

\footnotetext{
${ }^{1}$ For results of the measurement on the American Indian, see writer's "Physiological and Medical Observations, etc." p. II8.
} 
average body height than that of the highest vaults. In the former series there are only two individuals ( $15 \%$ ) of $1.65 \mathrm{~m}$. in stature or above, while in the equally as large series of the highest heads, there are seven (or nearly $54 \%$ ) of such statures.

KHARGA OASIS, MEN: RELATION OF HEIGHT OF HEAD TO STATURE, FORM OF HEAD AND SIZE OF HEAD

\begin{tabular}{|c|c|c|c|c|c|c|c|}
\hline \multicolumn{4}{|c|}{$\begin{array}{l}\text { Cases with smallest height of head } \\
(12.65 \mathrm{~cm} \text {. and below) }\end{array}$} & \multicolumn{4}{|c|}{$\begin{array}{l}\text { Cases with greatest height of head } \\
(\times 3.7 \mathrm{~cm} \text {. and above })\end{array}$} \\
\hline $\begin{array}{c}\text { Height of } \\
\text { head }\end{array}$ & Stature & $\begin{array}{c}\text { Cephalic } \\
\text { index }\end{array}$ & $\begin{array}{l}\text { Cephalic } \\
\text { module }\end{array}$ & $\begin{array}{l}\text { Height of } \\
\text { head }\end{array}$ & Stature & $\begin{array}{c}\text { Cephalic } \\
\text { index }\end{array}$ & $\begin{array}{l}\text { Cephalic } \\
\text { module }\end{array}$ \\
\hline $\mathrm{cm}$. & $\mathrm{cm}$. & & $\mathrm{cm}$ & $\mathrm{cm}$ & $\mathrm{cm}$ & & $\mathrm{cm}$ \\
\hline 12.30 & 164.5 & 75.8 & 15.0 & 13.70 & 165.0 & 73.4 & 15.7 \\
\hline 12.30 & I68.0 & 70.3 & 14.4 & 13.70 & I 55.2 & 75.0 & I5.8 \\
\hline 12.35 & 160.0 & 71.7 & 14.8 & 13.70 & 163.3 & 77.4 & 15.6 \\
\hline 12.50 & 163.7 & 77.8 & 14.8 & 13.70 & 169.4 & 73.5 & I6. I \\
\hline 12.50 & I 54.5 & 73.5 & I4.9 & 13.75 & 161.6 & 73.6 & 15.7 \\
\hline 12.55 & 169.4 & 72.4 & 14.8 & 13.80 & 169.4 & 80.1 & I 5.8 \\
\hline 12.55 & 163.5 & 68.2 & 14.9 & 13.80 & 160.0 & 71.6 & 15.7 \\
\hline 12.60 & 157.8 & 78.6 & 14.8 & I 3.80 & I 7I.I & 76.6 & 15.7 \\
\hline 12.60 & I58.5 & 75.5 & 15.2 & I 3.80 & I 59.6 & 74.3 & 15.7 \\
\hline 12.65 & I58.7 & 73.1 & 14.9 & I 3.85 & 167.1 & 74.7 & I5.7 \\
\hline 12.65 & 162.2 & 72.1 & I5.I & 13.90 & 150.6 & 75.3 & 15.3 \\
\hline 12.65 & 161.3 & 77.0 & I 5.2 & 14.10 & I68.3 & 72.7 & I6. I \\
\hline 12.65 & 164.1 & 77.6 & I5.0 & 14.15 & 171.3 & 72.9 & 16.2 \\
\hline \multicolumn{4}{|c|}{ Averages ( 13 cases): } & \multicolumn{4}{|c|}{ Averages ( 13 cases): } \\
\hline 12.53 & 162.0 & 74.1 & 14.9 & 13.83 & 164.0 & $74 \cdot 7$ & 15.8 \\
\hline
\end{tabular}

It then appears that higher stature tends in general to be accompanied with an absolutely higher head, than low stature. But there is no direct proportion between the increase in the height of the head and that of the stature. Among the lowest heads the proportional relation between the height of the head and the height of the body is as I: I2.I, while among the highest heads it is only as I : II.9. This indicates that the growth of the head in height, while it to some extent augments in accord with increasing stature, is in the main subject to other influences.

The most interesting comparison is that between the height of the head and the size of the same. The size of the head is most conveniently represented by the mean cephalic diameter or the cephalic module. Compared with this, it is found that low height of the head corresponds in general to a small head as a whole, and vice versa. ${ }^{1}$

\footnotetext{
${ }^{1}$ See in this connection Boas, F., The Cephalic Index, Amer. Anthropologist, N. S., I, I899, pp. 448-46I. All the statements advanced there are, however, not borne out by the present study.
} 
This condition is expressed not only by the averages, but is also illustrated by the fact that in the series of the lowest heads there

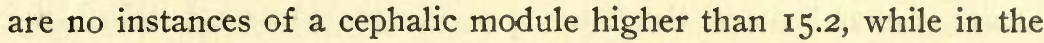
series of highest heads there is no module lower than $\mathrm{I}_{5} \cdot 3$.

It is further found, however, that in the case of the lowest heads, the average height of the head corresponds to the average cephalic module of the same heads only in the proportion of 84.I to 100, while in the case of the highest heads that proportion is as 87.6 to I00. This indicates that the height of the head increases faster than the size of the head as a whole, and hence to some extent independently of the same.

As to the relation of the height of the head to the length and breadth of the same, the following data show conclusively that the highest heads are also as a rule absolutely longer and broader than the lowest ones. Under normal conditions, therefore, an exceptional cephalic height is largely a function of the size of the head (which, in turn, as brought out before, stands in close connection with the stature).

KHARGA OASIS, MEN: RELATION OF HEIGHT OF HEAD TO LENGTH AND BREADTH OF SAME

\begin{tabular}{|c|c|c|c|c|c|}
\hline \multicolumn{3}{|c|}{$\begin{array}{l}\text { Cases with smallest height of head } \\
(12.65 \mathrm{~cm} . \text { and below })\end{array}$} & \multicolumn{3}{|c|}{$\begin{array}{l}\text { Cases with greatest height of head } \\
\text { ( } 13.7 \mathrm{~cm} \text {. and above.) }\end{array}$} \\
\hline Height of head & Length of head & Breadth of head & Height of head & Length of head & Breadth of head \\
\hline $\begin{array}{l}\mathrm{cm} . \\
12.30 \\
12.30 \\
12.35 \\
12.50 \\
12.50 \\
12.55 \\
12.55 \\
12.60 \\
12.60 \\
12.65 \\
12.65 \\
12.65 \\
12.65\end{array}$ & $\begin{array}{l}\mathrm{cm} . \\
\mathrm{I} 8.6 \\
18.2 \\
18.7 \\
18.0 \\
18.5 \\
18.5 \\
19.2 \\
17.8 \\
18.8 \\
18.6 \\
19.0 \\
18.7 \\
18.3\end{array}$ & $\begin{array}{l}\mathrm{cm} . \\
\text { I4.I } \\
\text { I2.8 } \\
\text { I3.4 } \\
\text { I4.0 } \\
\text { I3.6 } \\
\text { I3.4 } \\
\text { I3.I } \\
\text { I4.0 } \\
\text { I4.2 } \\
\text { I3.6 } \\
\text { I3.7 } \\
\text { I4.4 } \\
\text { I4.2 }\end{array}$ & $\begin{array}{l}\mathrm{cm} . \\
13.70 \\
13.70 \\
13.70 \\
13.70 \\
13.75 \\
13.80 \\
13.80 \\
13.80 \\
13.80 \\
13.85 \\
13.90 \\
14.10 \\
14.15\end{array}$ & $\begin{array}{c}\mathrm{cm} . \\
19.2 \\
19.2 \\
18.6 \\
20.0 \\
19.3 \\
19.1 \\
18.6 \\
19.4 \\
18.8 \\
19.0 \\
18.5 \\
19.8 \\
19.9\end{array}$ & $\begin{array}{c}\mathrm{cm} . \\
\text { I4.I } \\
\text { I4.4 } \\
\text { I4.4 } \\
\text { I4.7 } \\
\text { I4.2 } \\
14.2 \\
14.9 \\
13.9 \\
14.4 \\
14.2 \\
13.6 \\
14.4 \\
14.5\end{array}$ \\
\hline \multicolumn{3}{|c|}{ Averages ( 13 cases): } & \multicolumn{3}{|c|}{ Averages ( 13 cases): } \\
\hline 12.53 & -18.53 & 13.73 & 13.83 & 19.18 & 14.30 \\
\hline $\begin{array}{c}\text { Percental rela- } \\
\text { tion of height } \\
\text { to length and } \\
\text { breadth ....... }\end{array}$ & 67.6 & 91.3 & $\ldots$ & 72.1 & 96.7 \\
\hline
\end{tabular}


The mut:1al relation of the three main diameters, however, does not remain the same from the lowest to the highest heads. With the height it is as IIO.4 in the latter to IOO in the former, but with the breadth similar proportions are only 104.2 to 100 , and with the length ro3.5 to 100. Hence, the highest heads are not only highest absolutely, but also relatively to head length and breadth. The length has evidently lagged behind even slightly more than the breadth (C.I. in lowest heads 74 , in highest 74.6), but the difference is small and within the possibilities of accidental.

The above conditions do not fall, it seems to the writer, in the category of simple compensations; they are more likely directly connected with the anatomical peculiarities of the vault of the skull and are expressions, in the main, of the law of expansion of the skull in the directions of lesser resistance.

\section{Cephalic Module}

The sum of the length, breadth and height of the head, divided by three, gives the mean diameter of the head or the cephalic module, ${ }^{1}$

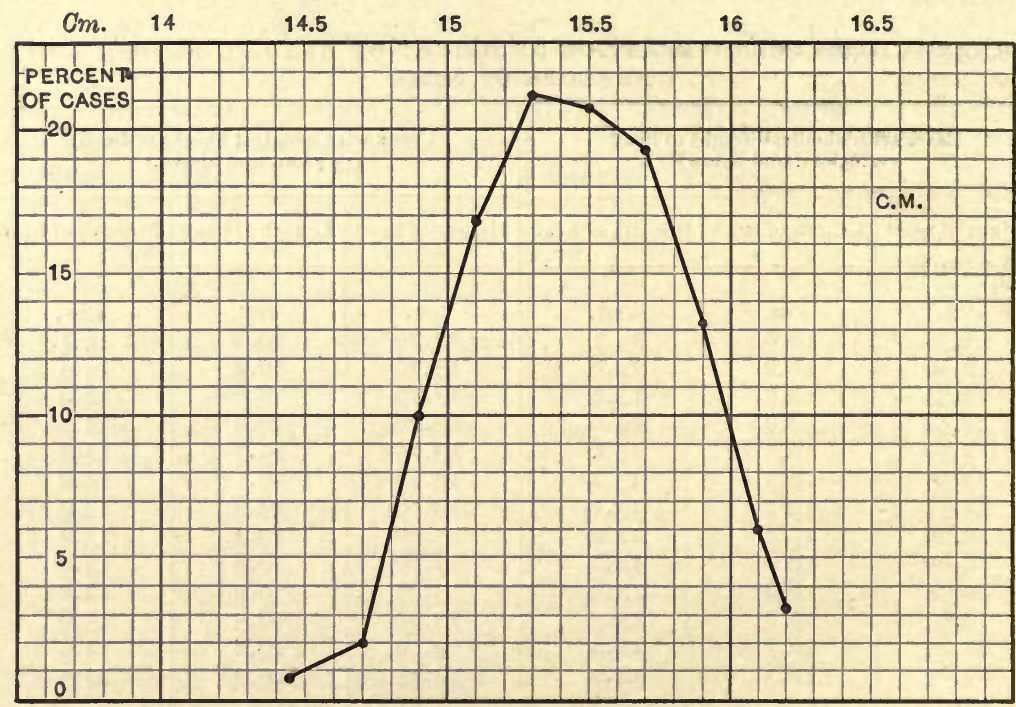

FIG. 5.-Curve showing the distribution of cephalic module (mean diameter of the head) among 150 adult males of the Kharga Oasis.

which, for comparative purposes, represents the size of the head

1 The term "modulus" was first employed by E. Schmidt, who designated by it (in Archiv f. Anthrop., Vol. 12, I879-'80, p. 179, and in his “Anthropologische Methoden" Leipzig, I888, p. 212 et seq.) the mean of the three diameters of the skull. 
better than the circumference or any other single dimension. When its relations to cranial capacity are better known, the cephalic module will serve capably, particularly in the form of its averages, as an index of the size of the brain.

The conditions shown by the Kharga Oasis men in regard to the cephalic module are given in the next table. The average is perceptibly smaller than that of the central or north Europeans, and also smaller than that of the majority of the tribes of the Indians. Some details concerning this point will be given in succeeding paragraphs. The range of variation is moderate, extending over I7.5 mm., which equals the variability of 0.057 per centimeter of the mean. The distribution of the module gives two fairly separate and distinct modes.

KHARGA OASIS, MEN: CEPHALIC MODULE. ${ }^{1}$

Number of observations: 150 .

Average: $15.4 \mathrm{~cm}^{2}$ (Ist $50: 15.45 ; 2 \mathrm{~d} 50: 15.31 ; 3 \mathrm{~d} 50: 15.45 \mathrm{~cm}$.)

Median : $15.38 \mathrm{~cm}$. Modes: I5.25 (I5.2I-I 5.3) and I5.55 (I5.5I-15.6) $\mathrm{cm}$.

Minimum : $14.43 \mathrm{~cm}$. Maximum : $16.18 \mathrm{~cm}$.

Table of frequencies:

\begin{tabular}{|c|c|c|c|c|c|c|c|c|c|}
\hline & 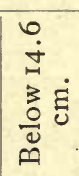 & $\begin{array}{l}\hat{\dot{J}} \\
\text { İ } \\
\stackrel{\Delta}{\sigma} \dot{\Xi} \\
\dot{J}\end{array}$ & 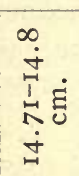 & 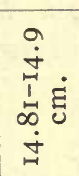 & 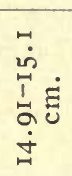 & 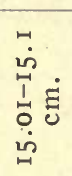 & 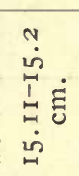 & 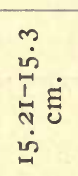 & $\begin{array}{l}\stackrel{+}{0} \\
\dot{1} \\
\stackrel{1}{m} \\
\dot{m} \\
\dot{m}\end{array}$ \\
\hline $\begin{array}{l}\text { Number of cases. } \\
\text { Per cent ......... }\end{array}$ & 0.7 & 0.7 & $\stackrel{2}{1.3}$ & $\stackrel{5}{3.3}$ & $\begin{array}{l}\text { I0 } \\
6.7\end{array}$ & $\begin{array}{l}10 \\
6.7\end{array}$ & $\begin{array}{l}15 \\
10.0\end{array}$ & $\begin{array}{l}17 \\
11.3\end{array}$ & $\begin{array}{l}15 \\
10.0\end{array}$ \\
\hline
\end{tabular}

\begin{tabular}{|c|c|c|c|c|c|c|c|c|}
\hline - & 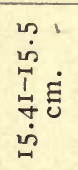 & 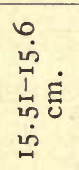 & $\begin{array}{l}\hat{n} \\
\dot{1} \\
\tilde{b} \\
\dot{g} \\
\dot{\theta}\end{array}$ & 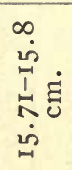 & 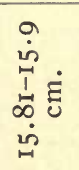 & $\begin{array}{l}\text { i. } \\
\stackrel{1}{\alpha} \dot{0} \\
\dot{\sim}\end{array}$ & $\begin{array}{l}\stackrel{3}{0} \\
\stackrel{1}{1} \dot{\Xi} \\
\dot{0} \\
\stackrel{0}{0}\end{array}$ & 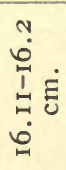 \\
\hline $\begin{array}{l}\text { Number of cases.. } \\
\text { Per cent............ }\end{array}$ & $\begin{array}{l}13 \\
8.7\end{array}$ & $\begin{array}{c}18 \\
12.0\end{array}$ & $\begin{array}{c}15 \\
10.0\end{array}$ & $\begin{array}{l}14 \\
9.3\end{array}$ & $\begin{array}{c}6 \\
4.0\end{array}$ & $2.0^{3}$ & $\begin{array}{c}2 \\
1.3\end{array}$ & $\begin{array}{l}\mathrm{I} \\
2.0\end{array}$ \\
\hline
\end{tabular}

1 Diameter antero-posterior max. + diameter lateral max. + auricular line - bregma height 3

${ }^{2}$ Probable error $= \pm 0.018$; standard deviation, $\sigma,=0.3312, \pm 0.013 ; \mathrm{co}-$ efficient of variability, $C,=2.151, \pm 0.084$.

The size of the head, expressed by the module or in any other manner, possesses in the whites and in other races, as is well known, certain relations to stature. This relation is not the same for all the different statures found in any group, nor is it equally proportionate to 
the different grades of stature. In general the head shows larger size the more considerable is the height of the body, and vice versa; however, in individuals above the average in stature the relative size of the head lags behind the body height, while in those of statures below the average the body height decreases in a more rapid ratio than the size of the head. The short men or women of any racial group, therefore, may be expected to possess heads absolutely smaller, but relatively to stature larger, than the tall individuals.

Precisely such conditions as outlined above are shown by the Kharga natives. They appear clearly in the succeeding tables, the first of which gives the average head-stature index, with its range of variation, in this series of Egyptians, while the second exhibits the variation of the index with that of stature.

\section{KHARGA OASIS, MEN: THE HEAD-STATURE INDEX, OR PER-MILLE RELATION OF CEPHAIIC MODULE (MEAN CRANIAL DIAMETER) TO STATURE (STATURE=1000)}

Number of observations: 150.

Average: $94.0 .^{1} \quad$ (Ist $50: 94.0 ; 2 \mathrm{~d} 50: 94.3 ; 3 \mathrm{~d} 50: 93.7$. )

Median: 94.I. Mode: 94.5 (94.I-95).

Minimum: 85.9. Maximum: IOI.8.

Table of frequencies:

\begin{tabular}{|c|c|c|c|c|c|c|c|c|c|}
\hline & $\begin{array}{l}\& \\
1 \\
\dot{\infty} \\
\infty\end{array}$ & $\begin{array}{l}\hat{\phi} \\
\stackrel{\infty}{\dot{\infty}}\end{array}$ & $\begin{array}{c}\stackrel{0}{0} \\
\stackrel{1}{\infty} \\
\dot{\infty}\end{array}$ & $\begin{array}{l}\not \\
\stackrel{\infty}{0} \\
\infty\end{array}$ & $\begin{array}{l}\stackrel{8}{\$} \\
\stackrel{8}{8}\end{array}$ & $\begin{array}{l}\overrightarrow{9} \\
\stackrel{8}{8}\end{array}$ & $\begin{array}{l}\text { ô } \\
\stackrel{\text { an }}{\Delta}\end{array}$ & $\begin{array}{l}0 \\
\stackrel{p}{0} \\
\text { a }\end{array}$ & $\begin{array}{l}\not{q} \\
\stackrel{\dot{\alpha}}{\alpha}\end{array}$ \\
\hline $\begin{array}{l}\text { Number of cases. } \\
\text { Per cent.......... }\end{array}$ & 0.7 & .. & $\begin{array}{c}6 \\
4.0\end{array}$ & $\stackrel{I}{1}$ & 3.3 & $\begin{array}{l}10 \\
6.7\end{array}$ & $\begin{array}{c}16 \\
10.7\end{array}$ & $\begin{array}{l}16 \\
10.7\end{array}$ & $\begin{array}{l}19.7 \\
12.7\end{array}$ \\
\hline
\end{tabular}

\begin{tabular}{|c|c|c|c|c|c|c|c|c|}
\hline & 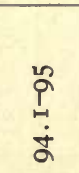 & \begin{tabular}{l}
8 \\
\multirow{2}{*}{} \\
$\dot{2}$
\end{tabular} & $\begin{array}{l}\hat{i} \\
\stackrel{1}{8} \\
\dot{8}\end{array}$ & 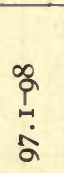 & $\begin{array}{l}8 \\
\not \\
\infty\end{array}$ & $\begin{array}{l}8 \\
\stackrel{1}{1} \\
\stackrel{1}{8}\end{array}$ & $\begin{array}{l}\overrightarrow{0} \\
\stackrel{1}{1} \\
\stackrel{4}{0} \\
\dot{8}\end{array}$ & 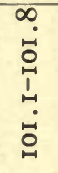 \\
\hline $\begin{array}{l}\text { Number of cases........ } \\
\text { Per cent............. }\end{array}$ & $\begin{array}{l}21 \\
14.0\end{array}$ & $\begin{array}{c}18 \\
12.0\end{array}$ & $\begin{array}{l}14 \\
9.3\end{array}$ & $\begin{array}{l}9 \\
6.0\end{array}$ & $2^{4} .7$ & 3.3 & 0.7 & 2.7 \\
\hline
\end{tabular}

${ }^{1}$ Probable error $= \pm 0.169 ;$ standard deviation, $\sigma,=3.066, \pm 0.119 ;$ coefficient of variability, $C,=3.258, \pm 0.127$.

The average head-stature index of the Kharga men with the mean body height of $163.8 \mathrm{~cm}$., namely 94.0 (94 mm. of body height to each centimeter of the mean head diameter), is about equal to that of male whites of $170 \mathrm{~cm}$. in stature (according to the writer's obser- 
vations) but is smaller (by about 2 points) than that of white men of the same body height as these Egyptians. It is even slightly smaller (by about I point) than the average in the American Indian. ${ }^{2}$ The head of the Kharga native is therefore both absolutely and relatively rather small.

KHARGA OASIS, MEN: CEPHALIC MODULE IN THE SHORTEST, MEDIUM AND TALLEST INDIVIDUALS

\begin{tabular}{|c|c|c|c|c|c|}
\hline \multicolumn{2}{|c|}{ Stature below $158 \mathrm{~cm}$. } & \multicolumn{2}{|c|}{ Stature $163.1-165 \mathrm{~cm}$} & \multicolumn{2}{|c|}{ Stature above $170 \mathrm{~cm}$. } \\
\hline Stature & $\begin{array}{l}\text { Per mille rela- } \\
\text { tion of cephalic } \\
\text { module to } \\
\text { stature }\end{array}$ & Stature & $\begin{array}{l}\text { Per mille rela- } \\
\text { tion of cephalic } \\
\text { module to } \\
\text { stature }\end{array}$ & Stature & $\begin{array}{l}\text { Per mille rela- } \\
\text { tion of cephalic } \\
\text { module to } \\
\text { stature }\end{array}$ \\
\hline I50.6 & IOI .8 & 163.1 & 92.8 & I 70.5 & 91.9 \\
\hline I52.3 & IOI.I & 163.2 & 97.6 & 170.7 & 92.4 \\
\hline I52.3 & 99.9 & I63.3 & 98.3 & I7I.I & 91.6 \\
\hline I53.6 & 97.2 & 163.3 & 95.3 & 171.3 & $94 \cdot 5$ \\
\hline I 54.5 & 96.2 & 163.4 & 97.0 & 172.2 & 98.0 \\
\hline I 55.2 & I0I. 6 & 163.4 & 96.2 & I 72.4 & 87.8 \\
\hline I 55.7 & 100.3 & 163.5 & $9 \mathrm{I} .4$ & I72.4 & 92.1 \\
\hline I 55.7 & 101.5 & 163.6 & 93.0 & 172.5 & 89.7 \\
\hline I 55.7 & 99.7 & 163.7 & 90.6 & 172.7 & 91.3 \\
\hline I 55.9 & 97.5 & 164.0 & $94 . I$ & 172.7 & 90.0 \\
\hline 156.0 & 95.6 & I64. I & $9 \mathrm{I} .7$ & 173.8 & 88.4 \\
\hline I 56.3 & 96.4 & 164.3 & 92.4 & $\mathrm{I} 74.5$ & 87.8 \\
\hline 156.5 & 99.2 & 164.4 & 93.6 & I 74.6 & 87.6 \\
\hline I 57.5 & 92.9 & 164.5 & 91.2 & & \\
\hline I 57.6 & $97 . I$ & 164.7 & 93.6 & & \\
\hline I 57.8 & 93.8 & 164.7 & $95 \cdot 5$ & & \\
\hline & & 164.8 & 94.6 & & \\
\hline & & 164.8 & $94 \cdot 5$ & & \\
\hline & & $\begin{array}{l}\text { I04.8 } \\
\text { I65.0 }\end{array}$ & $\begin{array}{l}95.7 \\
95.6\end{array}$ & & \\
\hline & & 165.0 & 95.0 & & \\
\hline \multicolumn{2}{|c|}{ Averages ( $\mathrm{I} 6$ individuals) } & \multicolumn{2}{|c|}{ ( $2 \mathrm{I}$ individuals) } & \multicolumn{2}{|c|}{ (I3 individuals) } \\
\hline 155.2 & 98.2 & 164.1 & 94.3 & 172.4 & 90.5 \\
\hline
\end{tabular}

The second table shows the effects of stature on the size of the head among the Oasis men themselves. These effects are seen to be pronounced and quite uniform; there is, of course, some individual variation, but it is small. In general the higher the stature, the

${ }^{2}$ Six groups of the latter show the following conditions:
50 Otomi men ........ $\begin{gathered}\text { Average } \\ \text { stature }\end{gathered}$
Average
cephalic module
2. 50 Aztec men ......... I6I.0
3. 50 Tarasco men ..... I63.I
I5.5
Head-stature
15.4
15.5
4. 53 Cora men ......... I64. I
15.8
I6.0
5. 50 Apache men ....... I70.0
6. 53 Pima men ......... I71.8
(306) Mean......... I64.9
15.9
15.7
index
97.3
95.8
95.0
96.3
94.0
92.3 
larger is the head absolutely, but the smaller relatively. If we take the mean stature and mean cephalic module as basis of comparison, we see that in advancing from these in either direction the changes in stature are more rapid than those of the head. As a result of this as we advance with stature above the mean, the head-stature index gradually diminishes, while if we progress below the mean body height, it gradually increases. Thus, as already stated, the shortest men have a head absolutely smaller but relatively to stature larger than the tallest.

The table under consideration and a still closer analysis of the data reveal further that the diminution of the head-stature index from the mean, as well as its augmentation, go on with a fair regularity and that the change averages, in well preserved adults, approximately $0.45 \mathrm{~mm}$. (of the mean head diameter) for each $1.0 \mathrm{~cm}$. of the stature. This 0.45 may well be regarded as the mean, stable, differential quotient between a regular theoretical and the actual increase of head size in proportion to stature.

The main conditions dealt with in the preceding paragraphs are, so far as the writer can ascertain, not peculiar to the Kharga natives. A similar variation of the head-stature index, and a similar value of the head-stature differential quotient, occur in the Indians and also in whites.

Regrettably, there are no means of direct comparison in this respect of the Kharga natives with the Valley Egyptians. Chantre's data are not detailed enough, besides which his head height is generally so low that it must have been measured by a method unlike that of the writer and can not be utilized for the determination of the cephalic module comparable with that used in this paper. Myers' data on the Egyptian soldiers, on the other hand, apply, as already mentioned, to men selected for their stature; moreover, Myers has measured the height of the head from the bi-meatus line to maximum elevation of the vault measurement, which on the average is about II $\mathrm{mm}$. in excess of the bi-meatus-bregma height measured by the writer. Nevertheless it is possible to make some indirect collation between the two series of subjects, resulting as follows:

\begin{tabular}{|c|c|c|c|c|c|}
\hline & $\begin{array}{c}\text { Length of } \\
\text { head }\end{array}$ & $\begin{array}{l}\text { Breadth of } \\
\text { head }\end{array}$ & $\begin{array}{l}\text { Height of } \\
\text { head (bi- } \\
\text { meatus line } \\
\text { to bregma) }\end{array}$ & & $\begin{array}{l}\text { ephalic } \\
\text { nodule }\end{array}$ \\
\hline $\begin{array}{l}\text { syptian soldiers from the } \\
\text { Valley (Myers) of average } \\
\text { stature above } 170 \mathrm{~cm} . . . . . .\end{array}$ & 19.5 & $14.4 \mathrm{ab}$ & out 13.5 & -about & 15.8 \\
\hline Kharga Oasis (H.) of aver- & 19.5 & 14.4 an & 5 & Tavout & 15.0 \\
\hline itur & I9.0 & I4.4 & 13.36 & & 15.6 \\
\hline
\end{tabular}


The above determinations, however imperfect, seem to indicate that the head of the Kharga native is even slightly smaller than that of the Valley Egyptian; the differences in this regard between the Oasis and Valley Egyptians are, however, as also indicated by Chantre's data, not very material.

Another point especially inquired into in connection with the cephalic module was its relation to the form of the head, as expressed by cephalic index. The interesting results are given below. They show that in this particular ethnic group there is, on the average, a perceptible difference in the size of the head between those of the lowest and those of the highest cephalic index and that the difference is in favor of the latter. This agrees well with what was indicated by some of the foregoing observations brought out in this paper.

KHARGA OASIS, MEN: RELATION OF SIZE OF HEAD, AS EXPRESSED BY THE MEAN CEPHALIC DIAMETER, OR MODULE, TO THE FORM OF HEAD AS SHOWN BY THE CEPHALIC INDEX

Head Forms Corresponding to Smallest and Largest Sizes of Head

\begin{tabular}{|c|c|c|c|}
\hline \multicolumn{2}{|c|}{20 lowest modules: $15.0 \mathrm{~cm}$. and below } & \multicolumn{2}{|c|}{${ }^{17}$ highest modules: $15.8 \mathrm{~cm}$. and above } \\
\hline Cephalic module & $\begin{array}{c}\text { Corresponding cephalic } \\
\text { index }\end{array}$ & Cephalic module & $\begin{array}{l}\text { Corresponding cephalic } \\
\text { index }\end{array}$ \\
\hline $\mathrm{cm}$ & & $\mathrm{cm}$ & \\
\hline 14.43 & 70.3 & I6. I8 & 72.9 \\
\hline 14.63 & $.73 \cdot 4$ & I6. I3 & 73.5 \\
\hline 14.78 & 78.0 & 16. 13 & $7 r .6$ \\
\hline $\mathrm{I} 4.80$ & 78.6 & 16.10 & 72.7 \\
\hline 14.82 & 72.4 & 16.05 & 73.0 \\
\hline 14.82 & $7 I .7$ & I 5.97 & 72.5 \\
\hline 14.83 & 77.8 & I 5.93 & $75 \cdot 4$ \\
\hline 14.87 & 79.6 & I 5.93 & 73.7 \\
\hline I 4.87 & 73.5 & I 5.88 & $7 I .4$ \\
\hline 14.92 & 69.1 & I 5.87 & 78.9 \\
\hline 14.93 & $75 . I$ & I 5.87 & 80.0 \\
\hline 14.93 & 76.4 & I 5.85 & 71.6 \\
\hline 14.93 & $75 \cdot 4$ & I5.85 & 80.9 \\
\hline 14.95 & 68.2 & I5.82 & 75.8 \\
\hline 14.95 & $73 . I$ & I 5.80 & 75.6 \\
\hline 14.97 & 75.0 & 15.80 & 79.8 \\
\hline 14.98 & $71 \cdot 3$ & 15.80 & $77 \cdot r$ \\
\hline 15 & 75.8 & & \\
\hline $\begin{array}{l}15 \\
15\end{array}$ & $\begin{array}{l}72.0 \\
70.7\end{array}$ & & \\
\hline & 80.8 & & \\
\hline
\end{tabular}

Averages:

\begin{tabular}{c|c|c|c}
14.87 & 73.9 & 15.94 & $75 . I$ \\
$\left(14.43^{-15.0)}\right.$ & $(68.2-79.6)$ & $(15.80-16.18)$ & $(71.4-80.9)$ \\
\hline
\end{tabular}


KHARGA OASIS, MEN: RELATION OF SIZE OF HEAD, AS EXPRESSED BY THE MEAN CEPHALIC DIAMETER, OR MODULE, TO THE FORM OF HEAD AS SHOWN BY THE CEPHALIC INDEX

Sizes of Head Corresponding to Most Oblong and to Most Rounded Head Shapes

\begin{tabular}{|c|c|c|c|}
\hline \multicolumn{2}{|c|}{22 lowest cephalic indices: below 72.0} & \multicolumn{2}{|c|}{ xg highest cephalic indices: above 78.0} \\
\hline Cephalic index & $\begin{array}{l}\text { Corresponding cephalic } \\
\text { module }\end{array}$ & Cephalic index & $\begin{array}{l}\text { Corresponding cephalic } \\
\text { module }\end{array}$ \\
\hline $\begin{array}{l}68.2 \\
69.1 \\
69.6 \\
70.2 \\
70.3 \\
70.7 \\
70.7 \\
70.9 \\
70.9 \\
71.2 \\
71.3 \\
71.3 \\
71.4 \\
71.6 \\
71.6 \\
71.6 \\
71.6 \\
71.6 \\
71.6 \\
71.7 \\
71.8 \\
71.8\end{array}$ & $\begin{array}{l}\mathrm{cm} . \\
14.95 \\
14.92 \\
15.15 \\
15.23 \\
14.43 \\
15.02 \\
15.77 \\
15.52 \\
15.08 \\
15.25 \\
14.98 \\
15.53 \\
15.88 \\
15.13 \\
15.13 \\
16.13 \\
15.85 \\
15.22 \\
15.70 \\
14.82 \\
15.23 \\
15.60 \\
\end{array}$ & $\begin{array}{l}78.1 \\
78.4 \\
78.5 \\
78.6 \\
78.8 \\
78.9 \\
78.9 \\
79.1 \\
79.4 \\
79.4 \\
79.5 \\
79.5 \\
79.7 \\
79.8 \\
79.8 \\
80.0 \\
80.1 \\
80.7 \\
80.9\end{array}$ & $\begin{array}{c}\mathrm{cm} . \\
15.32 \\
15.47 \\
15.40 \\
14.80 \\
15.48 \\
15.87 \\
15.03 \\
15.20 \\
15.77 \\
15.22 \\
14.87 \\
15.32 \\
15.42 \\
15.48 \\
15.80 \\
15.87 \\
15.77 \\
15.25 \\
15.85\end{array}$ \\
\hline \multicolumn{4}{|l|}{ Averages: } \\
\hline $\begin{array}{c}70.9 \\
(68.2-71.8)\end{array}$ & $\begin{array}{c}15.30 \\
(14.82-16.13)\end{array}$ & $\begin{array}{c}79.4 \\
(78 . I-80.9)\end{array}$ & $\begin{array}{c}15.43 \\
(14.80-15.87)\end{array}$ \\
\hline
\end{tabular}

THE FACE

\section{Chin-Hair Line Height}

The total height of the face in the Kharga men averages $17.6 \mathrm{~cm}$., which, compared with the same dimensions in other races, is rather low. ${ }^{1}$ The range of variation is quite large; this is due partly to the inclusion in the measurement of the forehead, which varies independently of the face proper. The variation amounts to $5 \mathrm{I} \mathrm{mm}$., or \pm 0.145 per $\mathrm{cm}$. of the average, which is more than shown by any of the principal head measurements. The curve of distribution (fig. 6) even when condensed, is not entirely uniform.

${ }^{1}$ Compare for this and other face measurements especially Weisbach, A., Körpermessungen verschiedenen Menschenrassen, Supplement z. Zeitchr. f. Ethnologie, Vol. 9, 1877; $8^{\circ}$ Berlin 1878; Pfitzner, W.: Social-anthropologische Studien Zeitschr. f. Morphol. und Anthrop., Vol. I, I899, and Vol. 3, I90I; and Myers, Chas. S., Contribution to Egyptian Anthropology, Jour. Anthr. Inst., Vol. 38, 1908, (detailed measurements only). 


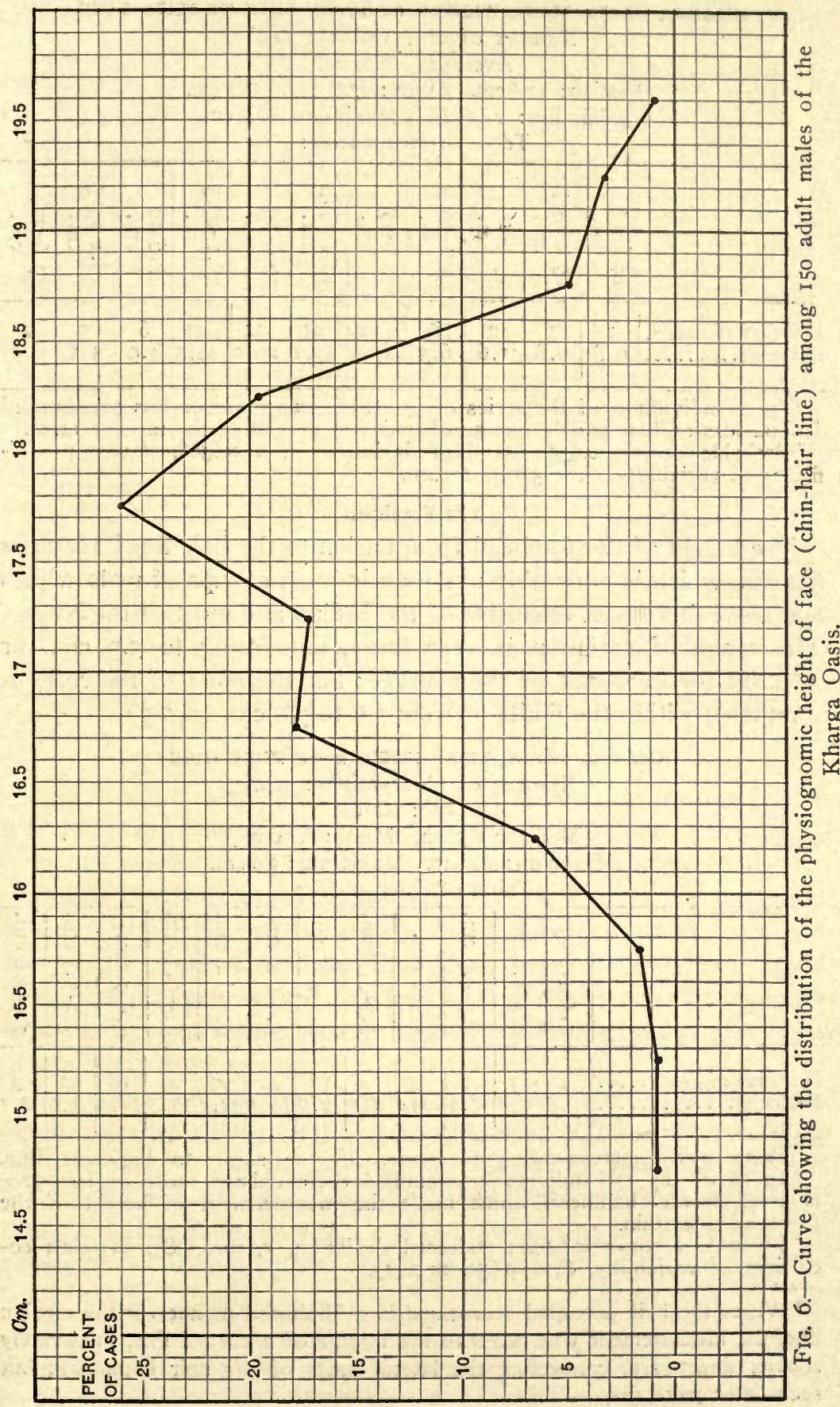


KHARGA OASIS, MEN: HEIGHT OF FACE, CHIN TO HAIR LINE

Number of observations: $123^{1}$

Average : $17.6 \mathrm{~cm}^{2}$

Median : $17.6 \mathrm{~cm}$. Mode: $I 7.8(I 7.6-18) \mathrm{cm}$.

Minimum : $14.6 \mathrm{~cm}$. Maximum $19.7 \mathrm{~cm}$.

Table of frequencies:

\begin{tabular}{|c|c|c|c|c|c|c|c|c|c|c|c|}
\hline & 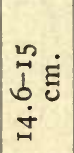 & 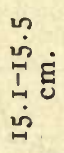 & $\begin{array}{l}b \\
\vec{b} \\
\dot{b} \\
\dot{1} \\
\dot{1}\end{array}$ & 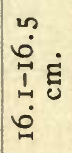 & $\begin{array}{ll}1 & \dot{1} \\
1 & E \\
0 & 0 \\
0 & \end{array}$ & 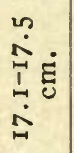 & 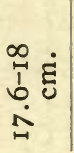 & 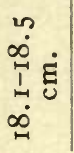 & 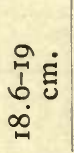 & 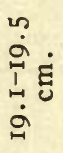 & $\begin{array}{l}\stackrel{i}{N} \dot{\Xi} \\
1 \\
\dot{0} \\
\stackrel{1}{0}\end{array}$ \\
\hline $\begin{array}{l}\text { Number of cases. } \\
\text { Per cent......... }\end{array}$ & $\begin{array}{c}\mathrm{I} \\
0.8\end{array}$ & $\stackrel{1}{1}$ & $\begin{array}{c}2 \\
1.6\end{array}$ & $\begin{array}{c}8 \\
6.5\end{array}$ & $\begin{array}{c}22 \\
17.9\end{array}$ & $\begin{array}{c}21 \\
17.1\end{array}$ & $\begin{array}{c}32 \\
26.0\end{array}$ & $\begin{array}{c}24 \\
19.5\end{array}$ & $\begin{array}{c}6 \\
4 \cdot 9\end{array}$ & $\begin{array}{c}5 \\
4 \cdot I\end{array}$ & $\begin{array}{c}\mathrm{I} \\
0.8\end{array}$ \\
\hline
\end{tabular}

${ }^{1}$ In 26 individuals of the series of 150 there was more or less pronounced frontal loss of hair and in one another defect prevented the measurement.

${ }^{2}$ Probable error $=0.035$; standard deviation, $\sigma,=0.6366, \pm 0.025$; coefficient of variability, $C,=5.634, \pm 0.2 \mathrm{rg}$.

\section{The Forehead}

The height of the forehead from nasion to the hair line ${ }^{1}$ averages $6.2 \mathrm{~cm}$., which is noticeably less than in most groups of male whites and also other races, exclusive of the Indian and most of the Negro. The range of variation is very large, amounting to $3.5 \mathrm{~cm}$., or $\mp 0.282$ for each unit of the average; but the mass of the cases is comprised within the limits of from 5.6 to $7.0 \mathrm{~cm}$. (fig. 7).

\section{KHARGA OASIS, MEN: HEIGHT OF FOREHEAD ${ }^{2}$}

Number of observations: $124 .^{2}$

Average: $6.2 \mathrm{~cm}^{8}$

Median : $6.3 \mathrm{~cm}$. Mode: $6.2 \mathrm{~cm}$.

Minimum: $4 . I \mathrm{~cm}$. Maximum: $7.6 \mathrm{~cm}$.

Table of frequencies:

\begin{tabular}{|c|c|c|c|c|c|c|c|c|c|c|c|c|}
\hline & $\begin{array}{l}\dot{g} \\
0 \\
m \\
\dot{I} \\
\stackrel{+}{+}\end{array}$ & $\begin{array}{l}\dot{E} \\
0 \\
0 \\
\dot{I} \\
\dot{I} \\
\dot{+}\end{array}$ & 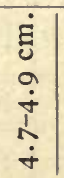 & 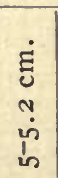 & $\begin{array}{l}\dot{\Xi} \\
\text { ? } \\
\dot{p} \\
\dot{?} \\
\dot{n}\end{array}$ & $\begin{array}{c}\dot{E} \\
u \\
\infty \\
\dot{p} \\
b \\
\dot{b} \\
\dot{n}\end{array}$ & 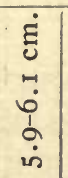 & $\begin{array}{c}\dot{g} \\
\dot{y} \\
+ \\
0 \\
1 \\
\sim \\
0 \\
0\end{array}$ & $\begin{array}{l}\dot{\varepsilon} \\
0 \\
\dot{\varphi} \\
\dot{0} \\
\dot{0}\end{array}$ & $\begin{array}{l}\dot{E} \\
\hat{U} \\
\dot{b} \\
\dot{0}\end{array}$ & 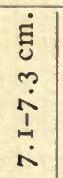 & $\begin{array}{l}\dot{\Xi} \\
u \\
0 \\
\stackrel{1}{1} \\
\dot{N}\end{array}$ \\
\hline $\begin{array}{l}\text { Number of cases...... } \\
\text { Per cent............ }\end{array}$ & $\begin{array}{c}\mathrm{I} \\
0.8\end{array}$ & $\begin{array}{c}1 \\
0.8\end{array}$ & $\begin{array}{c}2 \\
1.6\end{array}$ & ${ }^{4} .2$ & 3.2 & $\begin{array}{c}16 \\
12.9\end{array}$ & $\begin{array}{c}20 \\
16.1\end{array}$ & $\begin{array}{c}29 \\
23.4\end{array}$ & $\begin{array}{c}24 \\
19.3\end{array}$ & $\begin{array}{c}18 \\
14.5\end{array}$ & $\begin{array}{c}2 \\
1.6\end{array}$ & $\begin{array}{c}3 \\
2.4\end{array}$ \\
\hline
\end{tabular}

${ }^{1}$ From point corresponding to nasion in the skull, to the hair line.

${ }^{2}$ In 26 of the 150 individuals examined there existed more or less pronounced frontal baldness, which made the measurement of height of the forehead uncertain.

${ }^{3}$ Probable error $= \pm 0.036$; standard deviation, $\sigma,=0.5983, \pm 0.026$; coefficient of variability, $C,=9.650, \pm 0.413$.

${ }^{1}$ Where the hair extended downward in a V-shaped manner in the median line, the measurement was taken to the middle of a curved line, moderately convex downward, connecting the lateral parts of the hair boundary; but such cases were rare. 


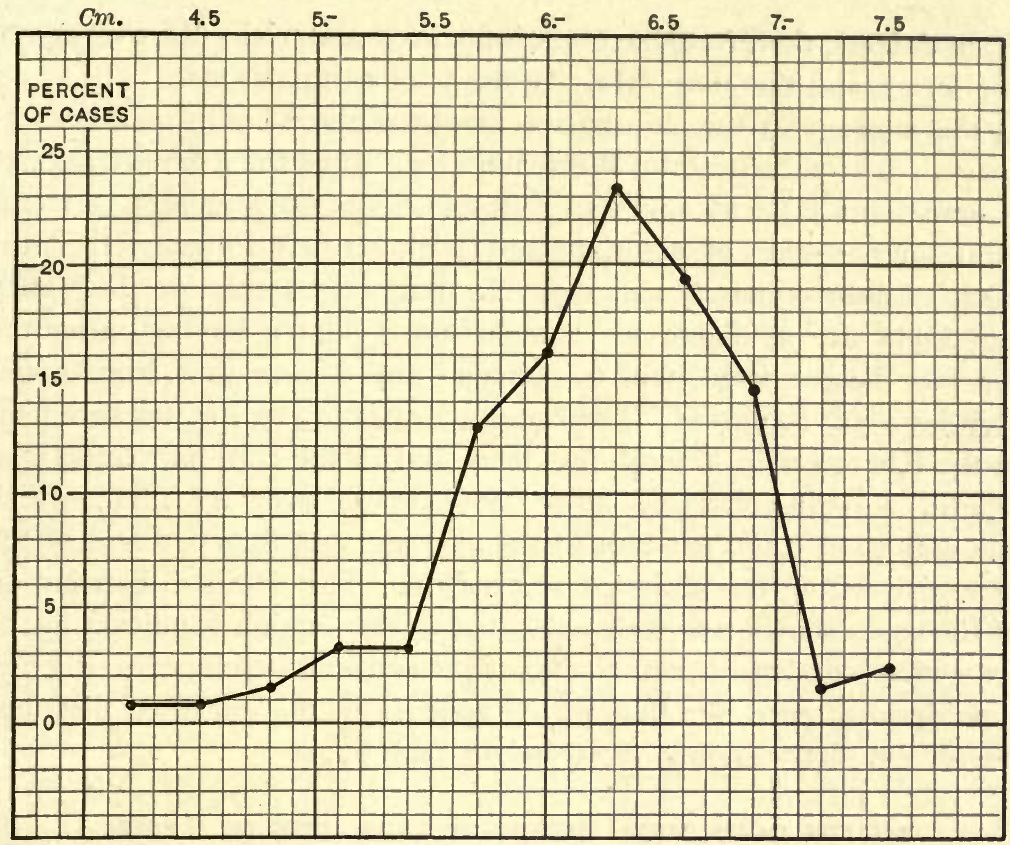

FIG. 7.-Curves showing the distribution of the height of the forehead (nasion-hair line) measurement, among I24 Kharga men free from calvitia.

\section{Chin-Nasion Height}

The distance from the lowest point of the chin in median line to a point corresponding to the middle of the fronto-nasal articulation, ${ }^{1}$ gives the height of the facial parts proper, speaking anatomically.

Due to this fact the measurement is more suitable for the study of the relations that exist between the development of the face and that of the vault of the skull than the total or physiognomic facial height, which includes the forehead and is affected by the variation of the latter, representing to an important extent external conditions of a portion of the vault.

The dimension (as also the total facial height) increases to some extent with age; but in old people it is frequently found to be more or less reduced, due to the wear or loss of the teeth and absorption of the alveolar processes. In the Kharga series no individual presented such conditions in a marked degree and no decided effects of age on the measurement, as will be seen later on, are perceptible.

${ }^{1}$ The point on the skin corresponding to nasion on the skull can in many cases be determined accurately by feeling, in others it must be estimated on the basis of the knowledge regarding the usual situation of the point in the cranium. It is generally somewhat above the middle of the intercanthic line. 
Such defects, therefore, have not influenced materially the average of the series, and this may safely be used for comparisons.

The average of the chin-nasion height in the Kharga men is II.35 cm.; I9 Jews measured by Weisbach (1. c.) gave the mean of $12.6,26$ Roumanians II.7, 25 northern Slavs I I. 6 and 20 Magyars I I.I cm., while a large series of Alsatians and Germans gave Pfitzner (1.c.) the mean of approximately $12.5 \mathrm{~cm}$. No data, regrettably, on the Valley Egyptians are available for comparison, Chantre having measured the face height from chin to ophryon and Myers that from upper alveolar point to nasion. The range of variation of the measurement in the Kharga men, though less than that of the chin-hair line facial height, is still relatively large; it extends over $43 \mathrm{~mm}$., which amounts to \pm 0.189 per unit of the average; but 85.4 per cent of the cases are within the limits of $10.5-12 \mathrm{~cm}$. The detailed distribution of the cases shows two well separated modes, which condition in the somewhat condensed curve (fig. 8) manifests itself in a distinct shouldering, quite like that which appears in the curve of distribution of the physiognomic facial height (fig. 6).

KHARGA OASIS, MEN: HEIGHT OF FACE, CHIN TO A POINT CORRESPONDING TO NASTION

Number of observations: I50.

Average : $I I .35 \mathrm{~cm}^{1}{ }^{1}$ (Ist $50:$ II.5; $2 \mathrm{~d} 50:$ II.25; $3 \mathrm{~d} 50:$ II.3 cm.).

Median: $I I .4 \mathrm{~cm}$. Modes : $I 0.9$ and $I I .6 \mathrm{~cm}$.

Minimum: $9.6 \mathrm{~cm}$. Maximum: $13.9 \mathrm{~cm}$.

Table of frequencies:

\begin{tabular}{|c|c|c|c|c|c|c|c|c|c|c|}
\hline$\leftrightarrow$ & $\begin{array}{l}\dot{E} \\
\dot{E} \\
0 \\
0\end{array}$ & 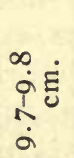 & 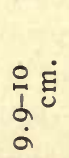 & 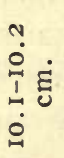 & 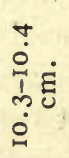 & 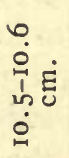 & 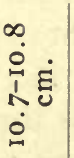 & 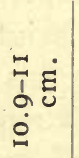 & 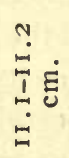 & 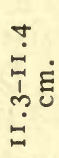 \\
\hline $\begin{array}{l}\text { Number of cases.... } \\
\text { Per cent............ }\end{array}$ & $\begin{array}{c}\text { I } \\
0.7\end{array}$ & $0_{0.7}^{I}$ & $\stackrel{2}{1.3}$ & $\begin{array}{l}\mathrm{I} \\
0.7\end{array}$ & $\begin{array}{l}1 \\
0.7\end{array}$ & $\begin{array}{r}\text { II } \\
7.3\end{array}$ & $\begin{array}{c}18 \\
12.0\end{array}$ & $\begin{array}{c}19 \\
12.7\end{array}$ & $\begin{array}{r}13 \\
8.7\end{array}$ & $\begin{array}{r}14 \\
9.3\end{array}$ \\
\hline
\end{tabular}

\begin{tabular}{|c|c|c|c|c|c|c|c|c|c|}
\hline & $\begin{array}{l}\dot{0} \\
\vdots \\
\dot{\Xi} \\
\dot{\Xi} \\
\Xi\end{array}$ & 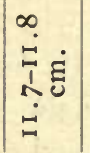 & $\begin{array}{l}\stackrel{N}{\Xi} \dot{\Xi} \\
\stackrel{\Xi}{0} \\
=\end{array}$ & 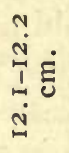 & 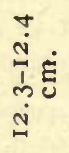 & 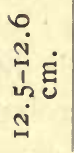 & 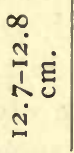 & 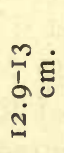 & $\begin{array}{l}\dot{E} \\
0 \\
0 \\
\dot{n}\end{array}$ \\
\hline $\begin{array}{l}\text { Number of cases } \ldots \ldots \ldots \ldots \\
\text { Per cent } . . . \ldots \ldots \ldots \ldots \ldots\end{array}$ & $\begin{array}{c}25 \\
16.7\end{array}$ & $\begin{array}{c}15 \\
10.0\end{array}$ & $\begin{array}{r}13 \\
8.7\end{array}$ & ${ }^{7} .7$ & 2.0 & $\stackrel{2}{1.3}$ & ${ }_{1.3}^{2}$ & $\begin{array}{l}\text { I } \\
0.7\end{array}$ & 0.7 \\
\hline
\end{tabular}

${ }^{2}$ Probable error $= \pm 0.035$; standard deviation, $\sigma, \pm 0.6366, \pm 0.025$; coefficient of variability, $C,=5.634, \pm 0.219$. 


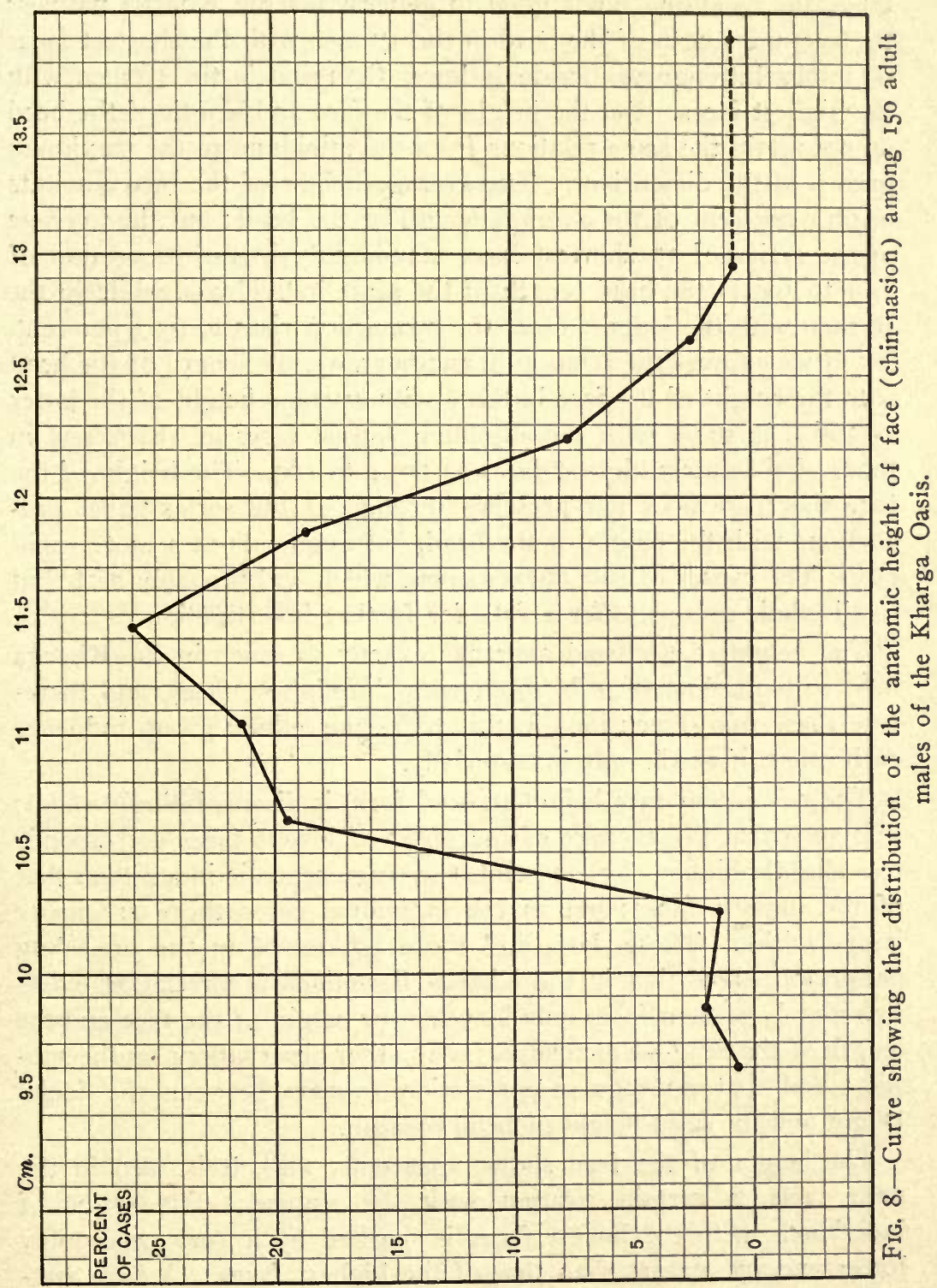


The height of the face is believed to be to some extent directly related to the length of the head, and, as shown in the following table, the condition holds good in general for the Kharga natives; the average length of the head in the I7 men with the shortest faces is, in absolute figures, decidedly lower than that in the 16 men with the highest faces. But the height of the face and length of the head do not retain the same relations from the minimum to the maximum grades of the dimensions. The average height of the face amounts to 6o.I per cent of the average length of the head; but the average of the series of I7 shortest faces stands only in the proportion of 55.I to roo to the head length of the same individuals, while in the I6 men with the longest faces the proportion rises to 65.3 per cent. Or, if we express the relation in another way, the length of the head is to the height of the face in those with average height of the latter as 166.5 , in those with the absolutely lowest faces as 181.5 , and in those of absolutely highest faces as I 53.2 to IoO. The height of the face therefore does not preserve throughout the series equal proportions with the length of the head, but augments at a more rapid rate. The causes of this phenomenon, which will probably be found in all ethnic groups, offer a field for further investigation.

The height of the head averages exactly as much in the Kharga men with the lowest as in those with the highest faces, and therefore these two dimensions in this particular ethnic group influence each other, if at all, only immaterially.

The relation of face height to head form is disappointingly small; it is such that the average of the series of lowest faces corresponds to a slightly higher (by 1.2 points) average cephalic index than that of the highest faces; but in the individual cases there are many irregularities. These data, and those spoken of in the preceding paragraph, show that in the Kharga Egyptians a correlation exists in a plainly evident form only between the height of the face and the length of the head-which agrees with other observations on the subject; and that no regular correlation appears between the facial height and the head height or head breadth.

The height of the face shows apparently also, it is seen in the next table, a certain relation with the stature. The series of individuals with the lowest faces is marked by a very perceptibly lower average stature than that of the highest faces. A high stature, therefore, carries with it, in general, a higher face. It however also carries with it, as seen in previous sections, a longer or rather larger head, and it is the latter with which the facial height is, 
KHARGA OASIS, MEN: RELATION OF HEIGHT OF FACE (CHIN-NASION), AND OF HEIGHT OF FOREHEAD, TO STATURE, HEAD LENGTH,

HEAD FORM AND AGE

I7 Shortest Faces of the Series

\begin{tabular}{|c|c|c|c|c|c|c|}
\hline $\begin{array}{c}\text { Height of face } \\
\text { chin to nasion } \\
\text { point }\end{array}$ & $\begin{array}{l}\text { Height of fore- } \\
\text { head: nasion } \\
\text { point to hair- } \\
\text { line }\end{array}$ & Stature & $\begin{array}{l}\text { Length of } \\
\text { the head }\end{array}$ & $\begin{array}{l}\text { Height of } \\
\text { the head }\end{array}$ & $\begin{array}{c}\text { Cephalic } \\
\text { index }\end{array}$ & $\begin{array}{l}\text { Approximate } \\
\text { age of sub- } \\
\text { ject }\end{array}$ \\
\hline $\mathrm{cm}$. & ${ }_{5.8}$ & $\begin{array}{l}\mathrm{cm} . \\
163.7\end{array}$ & $\mathrm{~cm}$. & $\begin{array}{ll}\mathrm{cm} . \\
\mathrm{I} 2.5\end{array}$ & $\mathrm{~cm}$. & $\begin{array}{c}\text { Years } \\
38\end{array}$ \\
\hline 9.8 & 6.0 & 165.2 & I9. 2 & I3.0 & 77.1 & 45 \\
\hline 9.9 & 6.4 & I 56.3 & 18.2 & I 3.0 & 76.9 & 40 \\
\hline 10.0 & 7.2 & 163.0 & I9.0 & 13.4 & 80.0 & 45 \\
\hline Io. I & 5.0 & I 57.5 & 17.7 & I 3.2 & 73.4 & 25 \\
\hline 10.4 & 6.9 & I59.7 & 18.4 & 12.7 & 75.0 & 24 \\
\hline 10.5 & 6.7 & I 52.3 & 18.0 & 13.3 & 79.4 & 50 \\
\hline 10.5 & $4 . I$ & 169.4 & 18.5 & 12.6 & 72.4 & 50 \\
\hline 10.5 & 6.1 & I 58.8 & 18.4 & 12.8 & 76.1 & 21 \\
\hline 10.5 & 5.6 & I6ั1.9 & 18.9 & 12.9 & 75.7 & 55 \\
\hline 10.5 & ? & I65.9 & 18.5 & 13.4 & 78.4 & 40 \\
\hline 10. 6 & 6.2 & 166.2 & I9.2 & 13.2 & 72.9 & 28 \\
\hline 10.6 & 5.9 & 164.7 & 19.6 & 13.3 & 72.4 & 32 \\
\hline 10.6 & 6.3 & 167.3 & I9. I & 13.2 & 70.2 & 50 \\
\hline 10.6 & ? & 167.5 & 19.0 & 13.6 & 78.9 & 45 \\
\hline 10.6 & 6.2 & 161.5 & 19.0 & 12.7 & 74.2 & 30 \\
\hline 10.6 & 6.0 & 167.5 & I8.6 & I 3.4 & 75.3 & 55 \\
\hline
\end{tabular}

Averages ( 16 individuals):

\begin{tabular}{|c|c|c|c|c|c|c|}
\hline $\begin{array}{r}10.3 \\
(9.6-10.6)\end{array}$ & $\begin{array}{r}6.0 \\
(4 \cdot I-7 \cdot 2)\end{array}$ & $\begin{array}{r}I 62.8 \\
\left(152.3^{-}\right. \\
169.4)\end{array}$ & $\begin{array}{r}18.7 \\
(17.7- \\
19.6)\end{array}$ & $\begin{array}{r}I 3.1 \\
(12.5- \\
13.6)\end{array}$ & $\begin{array}{c}75.7 \\
(70.2- \\
80.0)\end{array}$ & $\begin{array}{r}39.6 \\
(21-55)\end{array}$ \\
\hline
\end{tabular}

I6 Longest Faces of the Series

\begin{tabular}{|c|c|c|c|c|c|c|}
\hline $\begin{array}{l}\text { Height of face } \\
\text { chin to nasion } \\
\text { point }\end{array}$ & $\begin{array}{l}\text { Height of fore- } \\
\text { head: nasion } \\
\text { point to hair- } \\
\text { line }\end{array}$ & Stature & $\begin{array}{l}\text { Length of } \\
\text { the head }\end{array}$ & $\begin{array}{l}\text { Height of } \\
\text { the head }\end{array}$ & $\begin{array}{c}\text { Cephalic } \\
\text { index }\end{array}$ & $\begin{array}{l}\text { Approximate } \\
\text { age of sub- } \\
\text { ject }\end{array}$ \\
\hline $\begin{array}{l}\mathrm{cm} . \\
\mathrm{I} 2 . \mathrm{I}\end{array}$ & $\mathrm{cm}$. & I63. & $\begin{array}{l}\mathrm{cm} . \\
\text { I9.0 }\end{array}$ & $\begin{array}{l}\mathrm{cm} . \\
\text { I } 2.8\end{array}$ & cm. & $\begin{array}{c}\text { Years } \\
26\end{array}$ \\
\hline I2.I & 6.2 & 160.7 & I8.8 & 12.7 & 71.3 & 55 \\
\hline I2. I & 6.2 & I68.9 & 19.0 & 13.0 & 74.7 & 32 \\
\hline I2. I & ? & I 70.5 & 19.2 & I3. I & 76.6 & 45 \\
\hline 12.1 & 7.4 & 172.7 & 18.9 & I3. 4 & 79.4 & 50 \\
\hline 12.2 & & 165.0 & 19.7 & 13.3 & 75.0 & 55 \\
\hline 12.2 & 6.0 & 164.5 & I8.6 & I2. 3 & $75 . \delta$ & 52 \\
\hline 12.3 & 5.6 & I 72.4 & I8.6 & 12.8 & 75.3 & 32 \\
\hline I2. 4 & ? & I63.2 & 19.5 & I3.4 & 75.4 & 55 \\
\hline I2.4 & 5.8 & 168.3 & 18.7 & I2.9 & 72.7 & 50 \\
\hline 12.5 & $5 \cdot 3$ & I 59.6 & 19.1 & I3. 8 & 74.3 & 28 \\
\hline 12.6 & 6.7 & 166.1 & 20.0 & I 3.4 & 72.5 & 28 \\
\hline 12.7 & 6.8 & 161.7 & I8.8 & 13.3 & 76.1 & 40 \\
\hline 12.7 & 7.0 & 169.4 & 20.0 & 13.7 & 73.5 & 30 \\
\hline 12.9 & $?$ & 166. I & 19.2 & 12.8 & 73.4 & 45 \\
\hline I3.9 & ? & I65.6 & 19.3 & I3. 2 & 74.6 & 45 \\
\hline
\end{tabular}

Averages ( 16 individuals):

\begin{tabular}{|c|c|c|c|c|c|c|}
\hline $\begin{array}{r}12.5 \\
(12.1-13.9)\end{array}$ & $\begin{array}{r}6.3 \\
(5 \cdot 3-7 \cdot 4)\end{array}$ & $\begin{array}{r}I 66.1 \\
(159.6- \\
172.7)\end{array}$ & $\begin{array}{l}19.15 \\
(18.6- \\
20.0)\end{array}$ & $\begin{array}{r}I 3 . I \\
(12.3- \\
13.8)\end{array}$ & $\begin{array}{r}74.5 \\
(71.3- \\
79.4)\end{array}$ & $\begin{array}{r}41.7 \\
(26-55)\end{array}$ \\
\hline
\end{tabular}


in the main, directly correlated. The correlation of the dimensions of the facial parts with stature is wholly indirect, and it is scarcely suitable or useful to compare the two measurements. The lack of direct connection between the facial height and stature is illustrated by the fact that in the series under consideration the percental ratio, of the average stature to the average facial height amounts in those of shortest faces to $158 \mathrm{I}$, while in those with the longest faces it is only I329.

No definite correlation appears, further, between the height of the face and that of the forehead.

\section{Breadth of the Face}

(Diameter bizygomatic maximum.)

The greatest or bizygomatic breadth of the Kharga men shows the very moderate average of $13.15 \mathrm{~cm}$., and the rather small range of variation of $22 \mathrm{~mm}$., or \pm 0.083 per unit of the average. It is considerably less variable than the chin-nasion height of the face ( \pm o.I89 per unit of the mean) (fig. 9).

\section{KHARGA OASIS, MEN: BREADTH OF FACE (DIAMETER BIZYGOMATIC MAXIMUM)}

Number of observations: 150 .

Average: $13.15 \mathrm{~cm}^{2}{ }^{2}$ (Ist 50: $13.18 ; 2 \mathrm{~d} 50: 13.16 ; 3 \mathrm{~d} 50: 13.12 \mathrm{~cm}$.)

Median $13.2 \mathrm{~cm}$. Mode $13.4 \mathrm{~cm}$.

Minimum $I I .8 \mathrm{~cm}$. Maximum $I 4.0 \mathrm{~cm}$.

Table of frequencies:

\begin{tabular}{|c|c|c|c|c|c|c|c|c|c|c|c|c|}
\hline $\begin{array}{cc}\cdots \\
\because y & 4\end{array}$ & $\begin{array}{l}a \\
\tilde{\infty} \\
\infty \\
\dot{=}\end{array}$ & 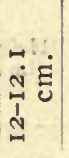 & 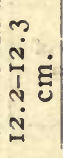 & 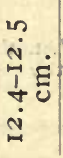 & 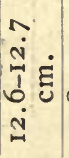 & 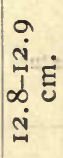 & $\begin{array}{l}\ddot{0} \\
\ddot{n} \\
\tilde{\sim} \\
\sim\end{array}$ & $\begin{array}{l}\stackrel{m}{2} \\
\ddot{1} \\
\\
\tilde{m} \\
\dot{\sim}\end{array}$ & $\begin{array}{l}\dot{n} \\
\ddot{m} \\
\ddot{H} \dot{E} \\
\dot{m} \\
\dot{m}\end{array}$ & 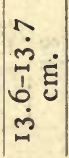 & $\begin{array}{l}\dot{a} \\
\dot{m} \\
\ddot{\infty} \\
\infty \\
\dot{m} \\
\dot{m}\end{array}$ & $\begin{array}{l}\dot{E} \\
\dot{U}\end{array}$ \\
\hline $\begin{array}{l}\text { Number of cases...... } \\
\text { Per cent............ }\end{array}$ & $\begin{array}{c}\mathrm{I} \\
0.7\end{array}$ & $\begin{array}{c}3 \\
2.0\end{array}$ & $\begin{array}{l}\cdots \\
\cdots\end{array}$ & $\begin{array}{c}8 \\
5.3\end{array}$ & $\begin{array}{l}12 \\
8.0\end{array}$ & $\begin{array}{l}23 \\
15.3\end{array}$ & $\begin{array}{c}24 \\
16.0\end{array}$ & $\begin{array}{c}24 \\
16.0\end{array}$ & $\begin{array}{c}27 \\
18.0\end{array}$ & $\begin{array}{c}16 \\
10.7\end{array}$ & $\begin{array}{l}10 \\
6.7\end{array}$ & $\stackrel{2}{1.3}$ \\
\hline
\end{tabular}

${ }^{2}$ Probable error $= \pm 0.023$; standard deviation, $\sigma,=0.425, \pm 0.017$; coefficient of variability, $C,=3.23, \pm 0.13$.

In general, in common with other facial breadths, the bizygomatic diameter possesses a high degree of correlation with the breadth of the head; and the same fact is observed in the Kharga Egyptians. As seen in the next table, the average breadth of head corresponding to the narrowest faces is decidedly lower than that corresponding to those of greatest breadth.

The proportional relation of the two dimensions follows what was observed in the case of the height of the face and length of the head - the face measurement augments at a more rapid rate. The ratio 
between the facial and the head breadth, taking the latter as Ioo, is in those of the narrowest faces 9r, in the broadest 95.5 .

The broader faces correspond also, on the average, to a perceptibly higher cephalic index, but, again, as in the case of the facial height, the correlation between the face dimension and the head form is in the mean far less and offers much more individual

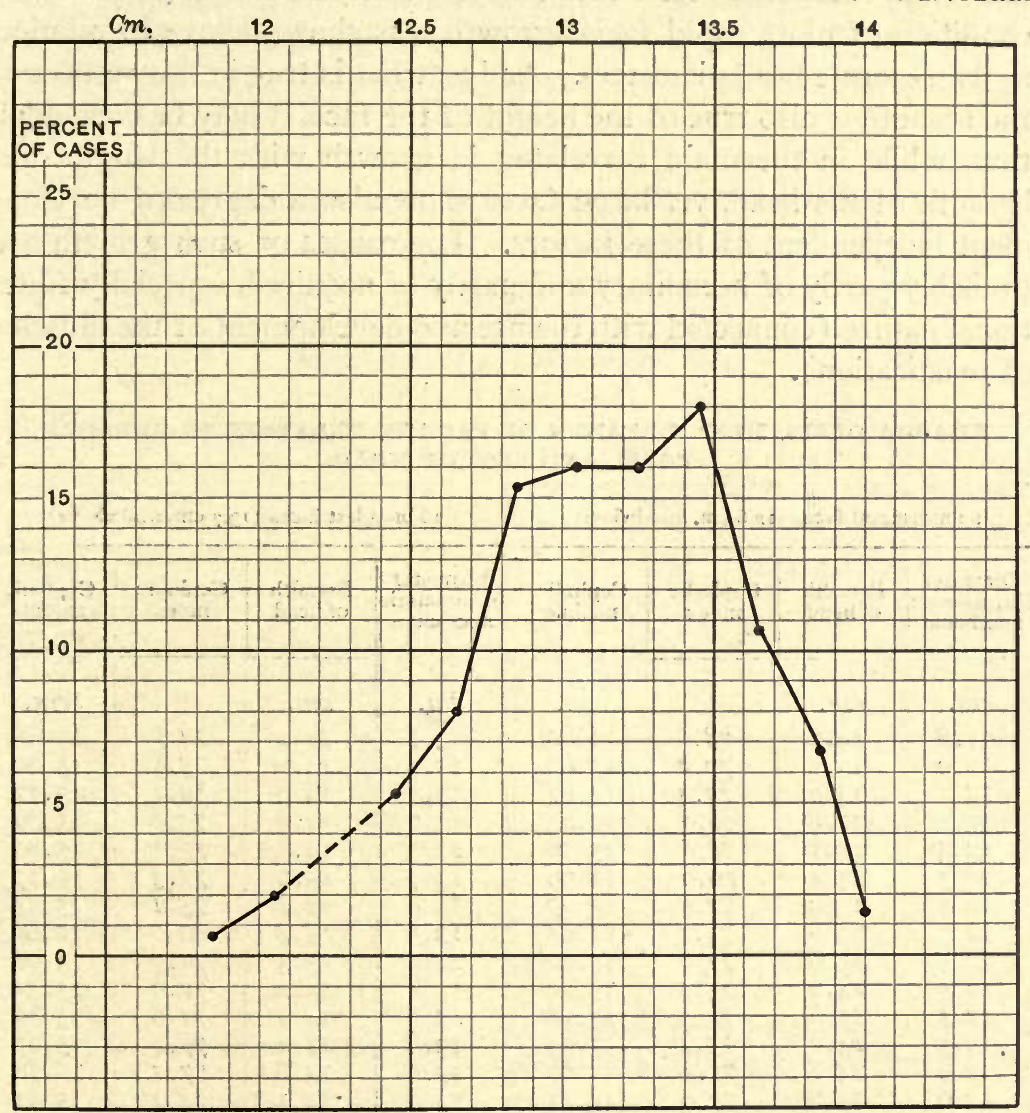

FIG. 9.-Curve showing the distribution of the diameter bizygomatic maximum in 150 adult men of the Kharga Oasis.

irregularity than that between the former and the corresponding diameter of the head. The whole can be reduced to the statement that face height stands, to a certain degree, in correlation with the head length and the face breadth with the head breadth; the correlation between the face measurements and head form are indirect and seemingly only proportionate to the liability of the corresponding head length or breadth to be accompanied with a definite head shape. 
The relation between the breadth of the face and the size of the head is such, that in general larger heads will show larger and hence also absolutely broader faces than small ones. But, as the ratio of the cephalic module to the face breadth indicates, being in the narrowest faces as $12 \mathrm{I} .5$ and in the broadest as only II 2.8 to IOO, the face augments at a greater rate than the size of the head, The same condition of more rapid facial growth was shown above in relation to the separate head diameters. And as what is true in this respect of the breadth is also true of the height of the face, it may be concluded that, while in the main correlated in growth with the length and breadth of the head, yet large faces show also a degree of development independent of these factors. The causes of such growth are probably partly of hereditary and partly of acquired, especially functional nature (connected with the use and development of the muscles of mastication).

KHARGA OASIS, MEN: BREADTH OF FACE IN RELATION TO BREADTH, FORM, AND SIZE OF HEAD

\begin{tabular}{|c|c|c|c|c|c|c|c|}
\hline \multicolumn{4}{|c|}{22 narrowest faces $(12.6 \mathrm{~cm}$. and below) } & \multicolumn{4}{|c|}{18 broadest faces ( $13.7 \mathrm{~cm}$. and above) } \\
\hline $\begin{array}{c}\text { Diameter } \\
\text { bizygomatic } \\
\text { maximum }\end{array}$ & $\begin{array}{l}\text { Breadth } \\
\text { of head }\end{array}$ & $\begin{array}{l}\text { Cephalic } \\
\text { index }\end{array}$ & $\begin{array}{l}\text { Cephalic } \\
\text { module }\end{array}$ & $\begin{array}{c}\text { Diameter } \\
\text { bizygomatic } \\
\text { maximum }\end{array}$ & $\begin{array}{l}\text { Breadth } \\
\text { of head }\end{array}$ & $\begin{array}{l}\text { Cephalic } \\
\text { index }\end{array}$ & $\begin{array}{l}\text { Cephalic } \\
\text { module }\end{array}$ \\
\hline $\mathrm{cm}$ & $\mathrm{cm}$. & & $\mathrm{cm}$. & $\mathrm{cm}$. & $\mathrm{cm}$. & & $\mathrm{cm}$ \\
\hline II. 8 & 14.0 & 78.6 & 14.80 & 13.7 & 14.2 & $74 \cdot 7$ & I5. 68 \\
\hline 12.0 & 13.2 & 70.7 & 15.02 & 13.7 & I4. I & 75.8 & 15.00 \\
\hline I2.1 & I3.0 & 73.4 & 14.63 & 13.7 & 14.9 & 80.1. & I 5.77 \\
\hline I2.I & 12.8 & 70.3 & 14.43 & 13.7 & 14.6 & 75.6 & 15.80 \\
\hline 12.4 & I4. I & 75.8 & 15.18 & 13.7 & 14.8 & 77.1 & 15.80 \\
\hline 12.5 & 13.4 & 70.9 & I5.08 & 13.7 & I 5.0 & $77 \cdot 3$ & I5.77 \\
\hline 12.5 & I3.9 & 72.8 & 15.27 & 13.8 & I4.2 & 75.1 & 15.45 \\
\hline 12.5 & 13.6 & $73 . I$ & 14.95 & 13.8 & 15.2 & 80.0 & 15.87 \\
\hline 12.5 & 13.6 & 71.6 & 15.22 & I3.8 & 13.4 & 71.3 & 14.98 \\
\hline 12.5 & 14.2 & 75.5 & 15.20 & I3.8 & 14.2 & 77.6 & 15.32 \\
\hline I2.5 & 13.6 & 72.0 & 15.18 & 13.8 & 14.4 & 71.6 & 15.85 \\
\hline 12.5 & 14.2 & 75.5 & I 5.33 & 13.8 & 14.4 & 77.4 & 15.27 \\
\hline 12.6 & I 4.8 & $77 . I$ & 15.67 & I3.8 & I 4.8 & $77 . I$ & I 5.78 \\
\hline 12.6 & I 3.8 & 73.0 & 15.25 & 13.9 & 14.1 & 73.4 & 15.37 \\
\hline 12.6 & 14.0 & 76.1 & 15.07 & 13.9 & 14.4 & 75.0 & I 5.77 \\
\hline 12.6 & 13.8 & 75.0 & 15.22 & 13.9 & I 4.3 & 76.1 & 15.52 \\
\hline 12.6 & 13.4 & 70.2 & 15.23 & 14.0 & 14.6 & 76.4 & 15.67 \\
\hline 12.6 & 13.5 & 71.8 & 15.23 & 14.0 & I 4.4 & 74.6 & 15.62 \\
\hline I2.6 & I3.I & 68.2 & I 4.95 & & & & \\
\hline 12.6 & 13.6 & $75 \cdot 3$ & 15.33 & & & & \\
\hline 12.6 & I 4.0 & 76.9 & 15.07 & & & & \\
\hline 12.6 & . 13.6 & 71.2 & 15.25 & & & & \\
\hline \multicolumn{8}{|c|}{ Averages: } \\
\hline $\begin{array}{r}12.45 \\
(11.8- \\
12.6)\end{array}$ & $\begin{array}{c}13.7 \\
(12.8 \\
14.8)\end{array}$ & $\begin{array}{c}73.4 \\
(68.2- \\
78.6)\end{array}$ & $\begin{array}{l}15.12 \\
(14.43- \\
15.67)\end{array}$ & $\begin{array}{c}13.8 \\
(13.7- \\
14.0)\end{array}$ & $\begin{array}{r}14.45 \\
(13.4- \\
15.2)\end{array}$ & $\begin{array}{c}75.9 \\
(71.6- \\
80.1)\end{array}$ & $\begin{array}{r}15.57 \\
(14.98- \\
15.87)\end{array}$ \\
\hline
\end{tabular}




\section{Facial Form}

The Physiognomic Facial Index $\left(\frac{\text { diameter bizygomatic max. } \times 100}{\text { chin-hair line height }}\right)$

The total physiognomic facial index averages in the Kharga men 74.7 , showing a tendency to leptoprosopy, which will be even more clearly apparent in the anatomical index. The range of variation is not excessive, extending over 16.3 points, or \pm 0.109 per point of the average. The distribution of the index presents two distinct modes (fig. IO).

KHARGA OASIS, MEN: FACIAL INDEX, PHYSIOGNOMIC

Number of individuals: I2I.

Average: 74.7 .

Median: 74.2. Modes: 73.3; 77.5

Minimum 68.1. Maximum 84.4.

Table of frequencies:

\begin{tabular}{|c|c|c|c|c|c|c|c|c|c|}
\hline & $\begin{array}{l}8 \\
1 \\
\sim \\
0\end{array}$ & $\begin{array}{l}R \\
1 \\
\sim \\
8\end{array}$ & $\begin{array}{l}\mathbb{R} \\
\stackrel{1}{0} \\
\stackrel{0}{R}\end{array}$ & $\begin{array}{l}\stackrel{N}{1} \\
\stackrel{2}{*}\end{array}$ & $\begin{array}{l}\stackrel{?}{I} \\
\stackrel{N}{N}\end{array}$ & $\frac{N}{\stackrel{+}{1}}$ & $\begin{array}{l}\stackrel{2}{1} \\
\stackrel{+}{ \pm}\end{array}$ & $\begin{array}{l}\mathfrak{R} \\
\stackrel{1}{\Perp} \\
\stackrel{1}{N}\end{array}$ & $\begin{array}{l}\hat{N} \\
\stackrel{1}{0}\end{array}$ \\
\hline $\begin{array}{l}\text { Number of cases. } \\
\text { Per cent........ }\end{array}$ & $\begin{array}{c}5 \\
4.1\end{array}$ & $\begin{array}{c}5 \\
4.1\end{array}$ & 5.8 & $\begin{array}{l}6 \\
5.0\end{array}$ & $\begin{array}{c}16 \\
13.2\end{array}$ & $\begin{array}{l}20 \\
16.5\end{array}$ & $\begin{array}{l}\text { II } \\
9.1\end{array}$ & $\begin{array}{l}\text { 10 } \\
8.3\end{array}$ & $\begin{array}{c}7 \\
5.8\end{array}$ \\
\hline
\end{tabular}

\begin{tabular}{|c|c|c|c|c|c|c|c|c|}
\hline & $\begin{array}{l}0 \\
1 \\
\\
\end{array}$ & $\begin{array}{l}R \\
i \\
0 \\
0\end{array}$ & $\begin{array}{l}\$ \\
1 \\
\dot{1} \\
\dot{1}\end{array}$ & $\begin{array}{l}\vec{p} \\
1 \\
\dot{\infty}\end{array}$ & $\begin{array}{c}\infty \\
\infty \\
\stackrel{\infty}{\infty} \\
\dot{\infty}\end{array}$ & 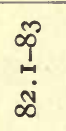 & $\begin{array}{c}\Phi \\
\stackrel{\infty}{\infty} \\
\infty \\
\infty\end{array}$ & $\begin{array}{l}\infty \\
\infty \\
\vdots \\
\dot{+}\end{array}$ \\
\hline $\begin{array}{l}\text { Number of cases........ } \\
\text { Per cent..................... }\end{array}$ & $\begin{array}{l}14 \\
11.6\end{array}$ & $\begin{array}{c}6 \\
5.0\end{array}$ & $\begin{array}{c}7 \\
5.8\end{array}$ & $\begin{array}{c}2 \\
1.6\end{array}$ & $\begin{array}{l}\mathrm{I} \\
0.8\end{array}$ & $\begin{array}{c}2 \\
1.6\end{array}$ & $\stackrel{\mathrm{I}}{0.8}$ & $\stackrel{\mathrm{I}}{0.8}$ \\
\hline
\end{tabular}

The Anatomical Facial Index $\left(\frac{\text { chin-nasion point height } \times \text { 10o }}{\text { diameter bizygomatic maximum }}\right)$

The anatomic, or facial index proper, averages 86.3, which approaches the boundary between meso- and leptoprosopy. ${ }^{1}$ Its range of variation is unexpectedly larger than that of the physiognomic index, extending over 30.7 points, or \pm 0.178 per unit of average, but the distribution of the index shows that 93.3 per cent of the cases are concentrated between the boundaries of 78 and 94. Only two individuals occur with chamæprosopy; in II9 the face is mesoprosopic and in 29 leptoprosopic (fig. IO).

${ }^{1}$ Chamaeprosopic, below 74.9; mesoprosopic, 75-89.9; leptoprosopic 90 and above. 


\section{KHARGA OASIS, MEN: FACIAL INDEX, ANATOMIC}

Number of observations: 150 .

Average: $86.3 .^{1}$ (Ist $50: 87.2 ; 2 \mathrm{~d} 50: 85.5 ; 3 \mathrm{~d} 50: 86$. I.)

Median: 86.5. Mode: 87 (86-87.9).

Minimum: 72.5. Maximum: 103.2.

Table of frequencies:

\begin{tabular}{|c|c|c|c|c|c|c|c|}
\hline & 产号 & 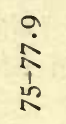 & $\begin{array}{l}a \\
\dot{a} \\
\infty \\
\infty\end{array}$ & $\begin{array}{l}a \\
\dot{1} \\
0 \\
\check{\infty} \\
\infty\end{array}$ & $\begin{array}{c}a \\
\dot{\infty} \\
0 \\
\alpha \\
\infty\end{array}$ & $\begin{array}{l}a \\
\dot{\infty} \\
\infty \\
\frac{1}{\infty}\end{array}$ & $\begin{array}{l}0 \\
\dot{\alpha} \\
\dot{\phi} \\
\dot{\infty}\end{array}$ \\
\hline 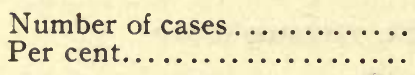 & $\stackrel{2}{1.3}$ & $\stackrel{2}{1.3}$ & $\begin{array}{l}\text { II } \\
7.3\end{array}$ & 9.0 & $\begin{array}{c}24 \\
16.0\end{array}$ & $\begin{array}{l}23 \\
15.3\end{array}$ & $\begin{array}{c}26 \\
17.3\end{array}$ \\
\hline
\end{tabular}

\begin{tabular}{|c|c|c|c|c|c|c|c|}
\hline$\therefore$ & $\begin{array}{l}a \\
\dot{\delta} \\
\infty \\
\infty\end{array}$ & $\begin{array}{l}\stackrel{a}{\dot{\alpha}} \\
\hat{a} \\
\dot{\alpha}\end{array}$ & $\begin{array}{l}a \\
\dot{\alpha} \\
\text { ๙ै }\end{array}$ & $\begin{array}{l}\dot{a} \\
\dot{o} \\
\dot{\alpha}\end{array}$ & $\begin{array}{l}\stackrel{a}{\hat{\alpha}} \\
\hat{a} \\
\stackrel{b}{\alpha}\end{array}$ & $\begin{array}{l}\text { aे } \\
\text { oे } \\
\text { o }\end{array}$ & 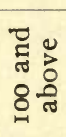 \\
\hline $\begin{array}{l}\text { Number of cases } \ldots \ldots \ldots \ldots \ldots \\
\text { Per cent........................... }\end{array}$ & $\begin{array}{c}24 \\
16.8\end{array}$ & $\begin{array}{l}12 \\
8.0\end{array}$ & $\begin{array}{l}\text { II } \\
7.3\end{array}$ & $\begin{array}{c}2 \\
1.3\end{array}$ & $\begin{array}{c}2 \\
1.3\end{array}$ & $\begin{array}{l}\mathrm{I} \\
0.7\end{array}$ & $\begin{array}{l}\mathrm{I} \\
0.7\end{array}$ \\
\hline
\end{tabular}

${ }^{1}$ Probable error $=0.260$; standard deviation, $\sigma,=4.724, \pm 0.184$; coefficient of variability, $C,=5.48, \pm 0.213$.

The relation of the facial form with the head form is shown in the next table. The average lowest facial indices, in other words the least oblong faces, correspond to a somewhat higher cephalic index, that is to somewhat more rounded heads, than the average of the highest indices or most oblong faces; and the same result appears when the lowest and highest cephalic indices are taken as the base of the comparison. The correspondence of the facial and head form is seen to be quite limited, which is rather surprising, for it was shown before that there exists a considerable direct correlation between, on one side, the facial height and the head length, and on the other between the facial and head breadth. And the weakness of reciprocal relations between the two indices is made still more evident by the many individual exceptions to their correspondence. A partial explanation at least of these facts appears to be possible by the assumption, justifiable by the conditions shown by the individual measurements, that the face dimensions vary to some extent independently of those of the head, and that this form of variation disturbs or obscures more or less the otherwise well established correlation of the parts. 


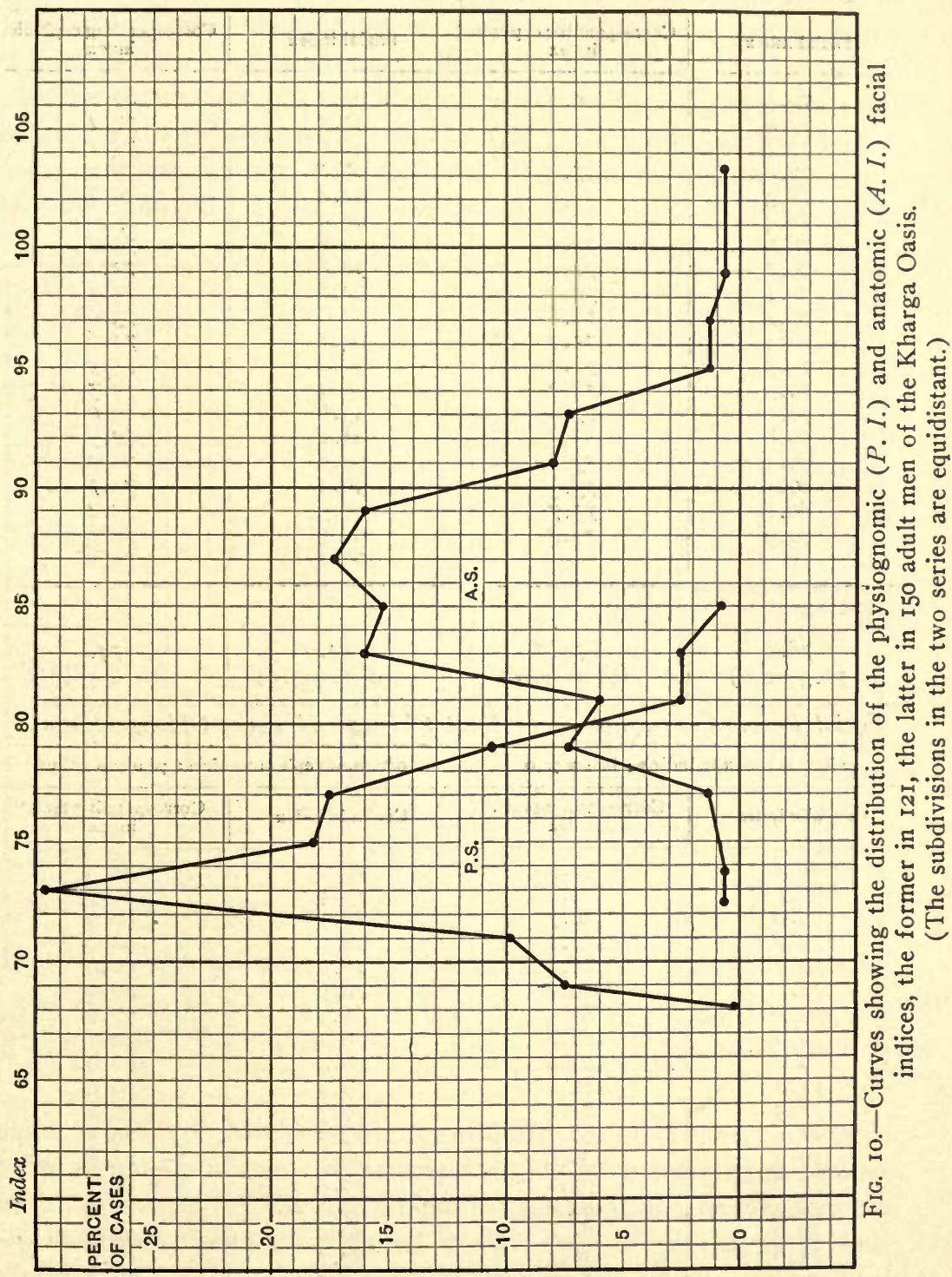


KHARGA OASIS, MEN: RETATION OF FACIAL (ANATOMIC) WITH CEPHALIC INDEX

Head Forms Corresponding to Most Oblong and to Least Oblong Faces

\begin{tabular}{c|c|c|c}
\hline \multicolumn{2}{c|}{ Iowest facial indices: 8r.o and below } & 20 highest facial indices: 9 r.o and above \\
\hline Facial index & $\begin{array}{c}\text { Corresponding cephalic } \\
\text { index }\end{array}$ & Facial index & $\begin{array}{c}\text { Corresponding cephalic } \\
\text { index }\end{array}$ \\
\hline 72.5 & 80.0 & 91.3 & 68.2 \\
73.8 & 77.8 & 91.5 & 77.4 \\
77.1 & 76.4 & 91.6 & $75 . I$ \\
77.8 & 77.1 & 92.1 & 73.3 \\
78.3 & 71.6 & 92.4 & 78.6 \\
78.4 & 75.8 & 92.4 & 75.0 \\
78.6 & 76.9 & 92.8 & 73.4 \\
79.1 & 72.9 & 92.8 & $73 . I$ \\
79.1 & 78.9 & 92.8 & 75.5 \\
79.3 & 75.8 & 92.9 & 73.0 \\
79.4 & 75.0 & 93.1 & 71.6 \\
79.5 & 72.4 & 93.2 & 75.3 \\
79.5 & 78.4 & 93.4 & 73.5 \\
79.6 & 77.1 & 93.6 & 70.9 \\
79.8 & 75.7 & 94.0 & 72.5 \\
80.1 & 73.2 & 94.8 & $76 . I$ \\
80.3 & 75.3 & 96.1 & 72.7 \\
80.8 & 75.7 & 96.9 & 75.4 \\
80.9 & 72.4 & 99.3 & 74.6 \\
& & 103.2 & 74.3 \\
\hline
\end{tabular}

\begin{tabular}{|c|c|c|c|}
\hline Averages: & & & \\
\hline $\begin{array}{c}78.6 \\
(72.5-80.9)\end{array}$ & $\begin{array}{c}75.7 \\
(71.6-80.0)\end{array}$ & $\begin{array}{c}94.0 \\
(91.3-103.2)\end{array}$ & $\begin{array}{c}74.0 \\
(68.2-78.6)\end{array}$ \\
\hline
\end{tabular}

\begin{tabular}{c|c|c|c}
\hline \multicolumn{2}{c}{ Facial Forms Corresponding to Most Oblong and Least Oblong Heads } \\
\hline \multicolumn{2}{c}{ 22 lowest cephalic indices; below 72.0} & \multicolumn{2}{|c}{ ro highest cephalicindices: 78.0 and above } \\
\hline Cephalic index & $\begin{array}{c}\text { Corresponding facial } \\
\text { index }\end{array}$ & Cephalic index & $\begin{array}{c}\text { Corresponding facial } \\
\text { index }\end{array}$ \\
\hline 68.2 & 91.3 & 78.1 & 88.4 \\
69.1 & 83.6 & 78.4 & 79.5 \\
69.6 & 88.5 & 78.5 & 90.9 \\
70.2 & 84.1 & 78.6 & 92.4 \\
70.3 & 88.4 & 78.8 & 90.8 \\
70.7 & 90.0 & 78.9 & 83.0 \\
70.7 & 89.5 & 78.9 & 79.1 \\
70.9 & 86.8 & 79.1 & 90.7 \\
70.9 & 93.6 & 79.4 & 82.0 \\
71.2 & 88.1 & 79.4 & 89.0 \\
71.3 & 81.1 & 79.5 & 86.5 \\
71.3 & 87.7 & 79.5 & 85.8 \\
71.4 & 86.6 & 79.7 & 84.4 \\
71.6 & 93.1 & 79.8 & 89.5 \\
71.6 & 84.8 & 79.8 & 72.5 \\
71.6 & 84.6 & 80.0 & 84.7 \\
71.6 & 78.3 & 80.1 & 87.8 \\
71.6 & 87.2 & 80.7 & 84.5 \\
71.6 & 89.5 & 80.9 & \\
71.7 & 83.6 & & \\
71.8 & 86.8 & & \\
71.8 & 84.9 & &
\end{tabular}

Averages:

\begin{tabular}{c|c|c}
70.9 & 86.9 & 79.4 \\
$(68.2-71.8)$ & $(78.3-93.1)$ & $(78.1-80.9)$
\end{tabular}




\section{THE NOSE \\ Nasal Height}

The dimensions of the nose are among the most useful and most frequently practiced anthropometrical determinations, and as there is but one system of landmarks for the measurements, the data available for comparison are much more numerous than those concerning other facial proportions. Unfortunately the existing series of nose measurements are not of uniform value, for the reason that, to those who are not well trained in anatomy, the determination of the nasion

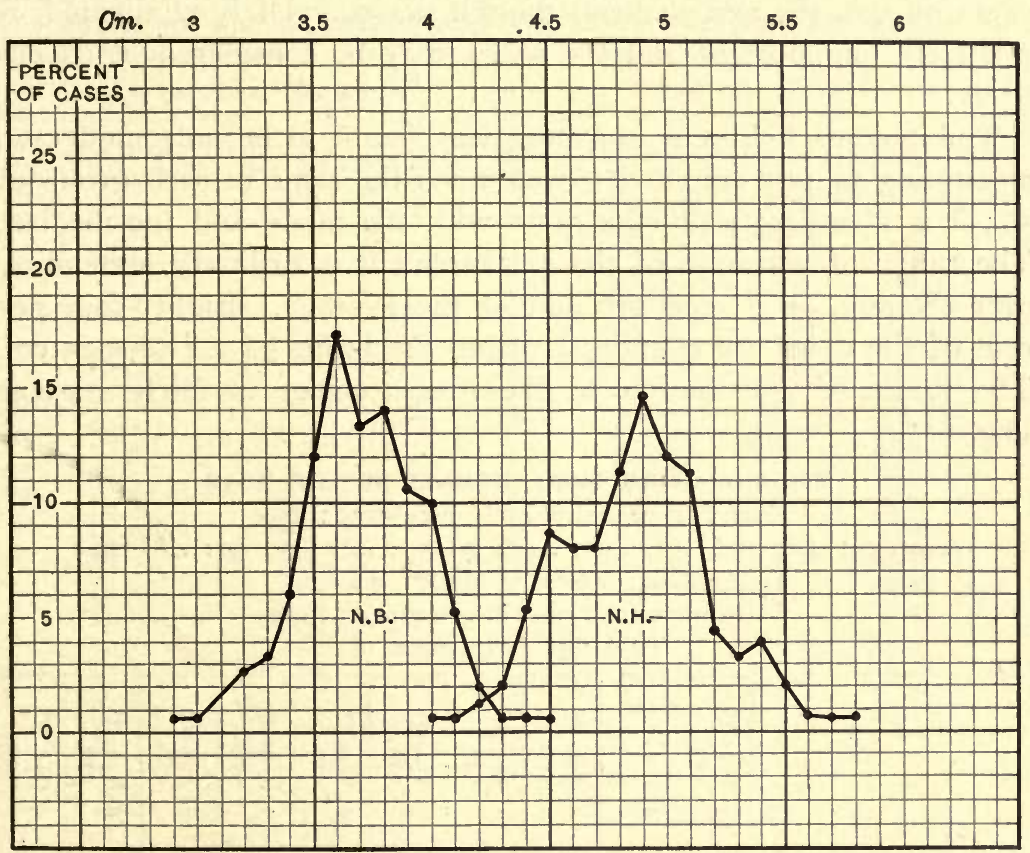

FIG. II.-Curves showing the distribution of the nasal height $(N . H$.$) and$ nasal breadth $(N . B$.$) measurements among 150$ adult men of the Kharga Oasis.

point is often a stumbling block; and also because the pronounced effect of age on the nose dimensions, which have received as yet but scanty attention. A habitual estimation of the nasion too high or too low, which is doubtless frequent in those who do not carry a clear mental view of the osseous parts of the face, is capable of resulting in important modifications of the results; and any series in which nose measurements of persons of old age are included must be regarded as altered from its normal standard in proportion to the number of the aged it embraces. The age differences in this respect 
are such that a series of measurements in any people on the adults in the prime of life and on those above 60 years of age will invariably stand well apart. The nose grows with the face far into the adult life, but with the advance of senility becomes often independently broader ; finally in those of old age its height tends rather towards diminution. The nasal index in the aged is thus heightened and the change is at times such that what formerly was a leptorhinic nose becomes mesorhinic, while one originally mesorhinic may become platyrhinic.

In the Kharga men, among whom but few were older than 55 years of age, the age element, though not completely eliminated, is relatively unimportant and the series may be considered in its entirety.

The average height of the nose was found to be only moderate, amounting to $4.87 \mathrm{~cm}$., and it was much the same in each group of 50 ; it is also practically the same with the mode and the median. The range of variation of the measurement is ordinary, extending over $18 \mathrm{~mm}$., or \pm 0.18 per unit of the average. Eighty-four per cent of the cases are contained within the limits of 4.4 to $5.25 \mathrm{~cm}$. The range of distribution of the measurement is fairly regular (fig. II).

KHARGA OASIS, MEN: HEIGHT OF THE NOSE

Number of individuals measured: 150.

Average: $4.87 \mathrm{~cm}^{1}$ (Ist $50: 4.9 \mathrm{I} ; 2 \mathrm{~d} 50: 4.82 ; 3 \mathrm{~d} 50: 4.87 \mathrm{~cm}$.)

Median: $4.9 \mathrm{~cm}$. Mode: $4.9 \mathrm{~cm}$.

Minimum: $4.0 \mathrm{~cm}$. Maximum: $5.8 \mathrm{~cm}$.

Table of frequencies:

\begin{tabular}{|c|c|c|c|c|c|c|c|c|c|c|}
\hline & $\begin{array}{l}\text { ஜ } \\
\dot{+} \dot{\Xi} \\
0 \\
\dot{\sigma}\end{array}$ & 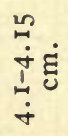 & 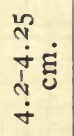 & 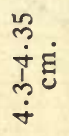 & 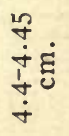 & 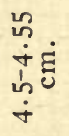 & 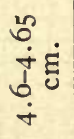 & 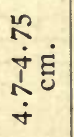 & $\begin{array}{l}\infty \\
\infty \\
\dot{\sigma} \\
\infty \\
\infty \\
\dot{\sigma}\end{array}$ & 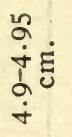 \\
\hline $\begin{array}{l}\text { Number of cases.... } \\
\text { Per cent........... }\end{array}$ & $\begin{array}{c}\mathrm{I} \\
0.7\end{array}$ & $\begin{array}{l}\text { I } \\
0.7\end{array}$ & $\stackrel{2}{1.3}$ & $2^{3} .0$ & $\begin{array}{c}8 \\
5.3\end{array}$ & $\begin{array}{r}13 \\
8.7\end{array}$ & $\begin{array}{r}12 \\
8.0\end{array}$ & $\begin{array}{r}12 \\
8.0\end{array}$ & $\begin{array}{c}17 \\
11.3\end{array}$ & $\begin{array}{c}22 \\
14.7\end{array}$ \\
\hline
\end{tabular}

\begin{tabular}{|c|c|c|c|c|c|c|c|c|c|}
\hline & 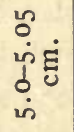 & 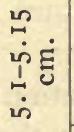 & 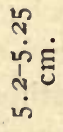 & 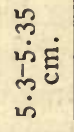 & 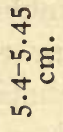 & $\begin{array}{l}\text { भ̆ } \\
\text { ம் } \\
\text { ம் } \\
\text { ம் }\end{array}$ & 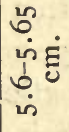 & 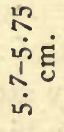 & $\begin{array}{l}\dot{E} \\
\infty \\
\infty \\
\dot{1}\end{array}$ \\
\hline 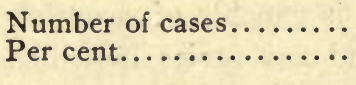 & $\begin{array}{c}18 \\
12.0\end{array}$ & $\begin{array}{c}17 \\
11.3\end{array}$ & ${ }_{4}^{7} .7$ & ${ }^{5} .3$ & $\begin{array}{c}6 \\
4.0\end{array}$ & $2^{3} .0$ & $0_{0.7}^{\text {I }}$ & $\begin{array}{c}\text { I } \\
0.7\end{array}$ & ${ }_{0.7}^{I}$ \\
\hline
\end{tabular}

${ }^{1}$ Probable error $= \pm 0.018$; standard deviation, $\sigma,=0.330, \pm 0.013 ;$ coefficient of variability, $C,=6.78, \pm 0.264$ 
A comparison with the other facial measurements shows that, as in other ethnic groups, so in the Kharga Egyptians the nasal height bears a close correlation with the height of the face. This condition is brought out very plainly in the following table. The nasal height does not, however, rise exactly proportionately with the facial height, but shows a slight retardation; this indicates an increase, with advancing height of face, not only in the absolute, but also in the relative height of the subnasal region.

KHARGA OASIS, MEN: RELATION OF THE FACIAL AND NASAL HEIGHT IN THOSE OF THE SHORTEST AND THOSE OF THE LONGEST FACES

\begin{tabular}{|c|c|c|c|}
\hline \multicolumn{2}{|c|}{17 shortest faces of the series } & \multicolumn{2}{|c|}{ x6 longest faces of the series } \\
\hline $\begin{array}{l}\text { Height of face, } \\
\text { chin-nasion point }\end{array}$ & Height of nose & $\begin{array}{c}\text { Height of face } \\
\text { chin-nasion point }\end{array}$ & Height of nose \\
\hline $\mathrm{cm}$ & $\mathrm{cm}$. & $\mathrm{cm}$. & $\mathrm{cm}$. \\
\hline 9.6 & $4 \cdot 5$ & I2. I & 5.0 \\
\hline $\begin{array}{l}9.8 \\
9.9\end{array}$ & $\begin{array}{l}4.2 \\
4.4\end{array}$ & $\begin{array}{l}\text { I2. I } \\
\text { I2. I }\end{array}$ & 4.8 \\
\hline 10.0 & $\begin{array}{l}4.4 \\
4.6\end{array}$ & I2.I & $\begin{array}{l}5.5 \\
5.1\end{array}$ \\
\hline IO.I & 4.6 & I2.I & 5.3 \\
\hline 10.4 & 4.0 & I2.2 & 5.0 \\
\hline 10.5 & 4.5 & 12.2 & 5.2 \\
\hline 10.5 & $4 \cdot 5$ & 12.3 & 5.2 \\
\hline 10.5 & 4.5 & 12.4 & 5.8 \\
\hline 10.5 & 4.7 & I2.4 & 5.05 \\
\hline 10.5 & 4.6 & I 2.5 & 4.7 \\
\hline 10.6 & $4 \cdot 4$ & 12.6 & 4.7 \\
\hline I0.6 & $4 \cdot 5$ & I 2.7 & 5.5 \\
\hline 10.6 & $4 \cdot 5$ & I 2.7 & 5.3 \\
\hline 10.6 & 4.7 & 12.9 & 5.0 \\
\hline 10.6 & $4 \cdot 4$ & I3.9 & $5 \cdot 7$ \\
\hline 10.6 & 4.6 & & \\
\hline 10.3 & $\begin{array}{c}4.5 \\
(4 \cdot 0-4 \cdot 7)\end{array}$ & 12.5 & $\begin{array}{c}5.2 \\
(4.7-5.8)\end{array}$ \\
\hline
\end{tabular}

(Nose height-face height index 43.7) (Nose height-face height index 4I.6)

\section{Nasal Breadth}

The breadth of the nose averages in the Kharga men $3.73 \mathrm{~cm}$., and the range of variation is larger than that of the nasal height, extending over $16 \mathrm{~mm}$., or \pm 0.216 per unit of the average. Eighty-nine per cent of the cases fall between 3.4 and $4.15 \mathrm{~cm}$. 


\section{KHARGA OASIS MEN: BREADTH OF THE NOSE}

Number of individuals measured: I50.

Average: $3.73 \mathrm{~cm}^{1}$ (Ist $50: 3.8 ; 2 \mathrm{~d} 50: 3.7 ; 3 \mathrm{~d} 50: 3.7 \mathrm{~cm}$.)

Median: $3.7 \mathrm{~cm}$. Mode: $3.6 \mathrm{~cm}$.

Minimum: $2.9 \mathrm{~cm}$. Maximum: $4.5 \mathrm{~cm}$.

Table of frequencies:

\begin{tabular}{|c|c|c|c|c|c|c|c|c|c|}
\hline & 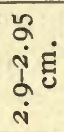 & 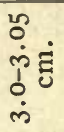 & 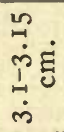 & 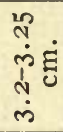 & $\begin{array}{l}\text { m̃ } \\
\dot{p} \\
\text { mु } \\
\dot{m}\end{array}$ & 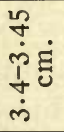 & 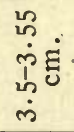 & 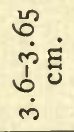 & 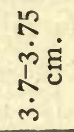 \\
\hline $\begin{array}{l}\text { Number of cases. } \\
\text { Per cent ......... }\end{array}$ & $\begin{array}{c}\text { I } \\
0.7\end{array}$ & $\begin{array}{c}\text { I } \\
0.7\end{array}$ & & $2^{4} .7$ & $3^{5} \cdot 3$ & $\begin{array}{c}9 \\
6.0\end{array}$ & $\begin{array}{c}18 \\
12.0\end{array}$ & $\begin{array}{c}26 \\
17.3\end{array}$ & $\begin{array}{c}20 \\
13.3\end{array}$ \\
\hline
\end{tabular}

\begin{tabular}{|c|c|c|c|c|c|c|c|c|}
\hline & 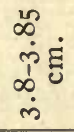 & 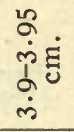 & $\begin{array}{l}\text { レ } \\
\dot{+} \dot{\Xi} \\
\text { ḋ } \\
\dot{+}\end{array}$ & 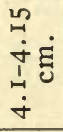 & 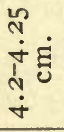 & 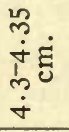 & 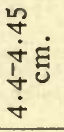 & $\begin{array}{l}\dot{\Xi} \\
\text { un } \\
\dot{\forall}\end{array}$ \\
\hline $\begin{array}{l}\text { Number of cases......... } \\
\text { Per cent.............. }\end{array}$ & $\begin{array}{c}21 \\
14.0\end{array}$ & $\begin{array}{l}16 \\
10.7\end{array}$ & $\begin{array}{l}15 \\
10.0\end{array}$ & $\begin{array}{c}8 \\
5.3\end{array}$ & $\begin{array}{c}3 \\
2.0\end{array}$ & $\begin{array}{c}\text { I } \\
0.7\end{array}$ & $\begin{array}{c}\text { I } \\
0.7\end{array}$ & $\begin{array}{c}\text { I } \\
0.7\end{array}$ \\
\hline
\end{tabular}

${ }^{1}$ Probable error $= \pm 0.014$; standard deviation, $\sigma,=0.263, \pm 0.0107$; coefficient of variability, $C,=7.06, \pm 0.27$.

KHARGA OASIS, MEN: RELATION OF THE FACIAL AND NASAL BREADTH IN THOSE OF THE SHORTEST AND THOSE OF THE LONGEST FACES

\begin{tabular}{|c|c|c|c|}
\hline \multicolumn{2}{|c|}{22 narrowest faces } & \multicolumn{2}{|c|}{18 broadest faces } \\
\hline $\begin{array}{c}\text { Diameter } \\
\text { bizygomatic maximum }\end{array}$ & Breadth of nose & $\underset{\text { bizygomatic maximum }}{\text { Diamer }}$ & Breadth of nose \\
\hline II 8 & 3.25 & 13.7 & 3.8 \\
\hline 12.0 & 3.9 & 13.7 & 3.7 \\
\hline I2. I & 3.75 & 13.7 & 3.65 \\
\hline 12.1 & 3.35 & 13.7 & 3.7 \\
\hline 12.4 & 3.6 & 13.7 & 3.95 \\
\hline I 2.5 & 3.65 & 13.7 & 3.7 \\
\hline 12.5 & 3.8 & 13.8 & 3.8 \\
\hline 12.5 & $3 \cdot 5$ & I3.8 & 3.9 \\
\hline 12.5 & 3.7 & I3.8 & 3.5 \\
\hline 12.5 & $3 \cdot 3$ & I 3.8 & 4.15 \\
\hline 12.5 & 3.6 & 13.8 & 3.9 \\
\hline 12.5 & 3.6 & 13.8 & 3.65 \\
\hline 12.6 & 3.9 & 13.8 & 3.6 \\
\hline 12.6 & 3.65 & 13.9 & 3.65 \\
\hline 12.6 & 3.6 & 13.9 & 3.8 \\
\hline 12.6 & 3.65 & I 3.9 & 3.65 \\
\hline 12.6 & 3.9 & 14.0 & 3.8 \\
\hline I2.6 & 3.65 & 14.0 & 3.5 \\
\hline 12.6 & $3 \cdot 3$ & & \\
\hline 12.6 & 3.8 & & \\
\hline 12.6 & $3 \cdot 5$ & & \\
\hline 12.6 & 3.8 & & \\
\hline 12.45 & $\begin{array}{c}3.62 \\
(3.25-3.9)\end{array}$ & 13.8 & $\begin{array}{c}3.75 \\
(3 \cdot 5-4 \cdot 15)\end{array}$ \\
\hline
\end{tabular}


As the height of the nose stands in correlation with the height of the face, so the breadth of the organ is correlated with facial breadth. The correspondence of the two dimensions in the Kharga natives is, however, not quite so close as in the case of the height, and individual exceptions are much more frequent, due to the variability and to some extent independent development of the zygomatic arches, which are included in the face measurement. The dimensions of the arches are influenced, it is well known, by the development of the temporal muscles.

\section{Nasal Index $\left(\frac{\text { breadth of nose } \times 100}{\text { height of nose }}\right)$.}

The average nasal index of the Kharga men, 76.6, is typically mesorhinian. It corresponds closely, as will be shown below, to that of the Valley Egyptians, the Bedjah Nubians and also some of the Berbers and other non-negroid African peoples. It is moderately higher than that of the pure Arabs and that of the whites, but is decidedly lower than that of the Soudan and other negroes.

\section{KHARGA OASIS, MEN: NASAI INDEX}

Number of observations: I50.

Average: $76.59 .^{1} \quad$ (Ist $50: 77 ; 2 \mathrm{~d} 50: 76.8 ; 3 \mathrm{~d} 50: 75.8$. )

Median 76.3. Mode: 73.5 (72.6-75).

Minimum: 56.7. Maximum: 95.12.

Table of frequencies:

\begin{tabular}{|c|c|c|c|c|c|c|c|c|c|}
\hline & 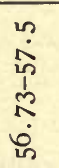 & $\begin{array}{l}8 \\
1 \\
1 \\
\text { in }\end{array}$ & $\begin{array}{l}\ddot{2} \\
\stackrel{2}{0} \\
\stackrel{1}{*} \\
\dot{8}\end{array}$ & $\begin{array}{l}\text { జூ } \\
\text { bे } \\
\text { రీ }\end{array}$ & 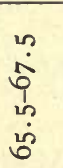 & $\begin{array}{l}\stackrel{R}{1} \\
b \\
\hat{b}\end{array}$ & $\begin{array}{l}\stackrel{n}{N} \\
\stackrel{1}{1} \\
\stackrel{0}{R}\end{array}$ & $\begin{array}{l}\stackrel{2}{\hat{b}} \\
\dot{N}\end{array}$ & 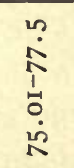 \\
\hline $\begin{array}{l}\text { Number of cases. } \\
\text { Per cent ......... }\end{array}$ & $\begin{array}{l}I \\
0.7\end{array}$ & $\begin{array}{l}\mathrm{I} \\
0.7\end{array}$ & $2^{4} .7$ & $\begin{array}{c}I \\
0.7\end{array}$ & $\begin{array}{c}6 \\
4.0\end{array}$ & ${ }^{9} .0$ & $\begin{array}{l}19 \\
12.7\end{array}$ & $\begin{array}{c}23 \\
15 \cdot 3\end{array}$ & $\begin{array}{c}21 \\
14.0\end{array}$ \\
\hline
\end{tabular}

\begin{tabular}{|c|c|c|c|c|c|c|c|c|}
\hline & $\begin{array}{l}8 \\
1 \\
1\end{array}$ & $\begin{array}{l}\text { n } \\
\dot{\alpha} \\
1 \\
\stackrel{\infty}{\infty}\end{array}$ & $\begin{array}{l}\infty \\
\infty \\
1 \\
0 \\
\infty \\
\infty\end{array}$ & $\underset{\infty}{\stackrel{\sim}{\infty}} \underset{\infty}{\infty}$ & 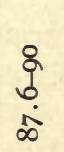 & $\begin{array}{l}n \\
\dot{i} \\
\stackrel{9}{q} \\
\ddot{8}\end{array}$ & 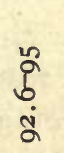 & $\ddot{2}$ \\
\hline $\begin{array}{l}\text { Number of cases ........ } \\
\text { Per cent.............. }\end{array}$ & $\stackrel{21}{14.0}$ & $\begin{array}{l}14 \\
9.3\end{array}$ & $\begin{array}{c}6 \\
4.0\end{array}$ & $\begin{array}{l}12 \\
8.0\end{array}$ & $3 \cdot 3$ & ${ }_{2}^{3} .0$ & $\stackrel{3}{2.0}$ & $\begin{array}{l}1 \\
0.7\end{array}$ \\
\hline
\end{tabular}

${ }^{1}$ Probable error \pm 0.403 ; standard deviation, $\sigma,=7.320, \pm 0.285$; coefficient of variability, $C,=9.5 \mathrm{I}, \pm 0.37 \mathrm{I}$. 
As to comparative data, we have especially the measurements of Chantre and Myers on the Egyptians and Nubians, and those of Collignon on the Tunisians and various other more western North Africans. Chantre's records are, regrettably, of only limited use, as his measurements of the height of the nose, due to some peculiarity of his method, are too low and his nasal indices result correspondingly high. Nevertheless they show a fairly close relation of the nasal index in the several Egyptian and Nubian (Bedjah) groups that were examined. Myers' observations, though applying to a more heterogeneous material than that of Kharga and one composed of only young men, give results that show a close accordance with those from the Oasis. The mean nasal index of 349 Mahommedan soldiers is 75.83 and that of 42 Copts 75.8 . The index augments from north to south, ranging from 73.4 in the district of Dakahlia to 78.I at Assiut (in the same latitude as Kharga) and to 78.9 in that of Kena. An abstract of Collignon data and those he quotes, are as follows:

NASAL INDEX IN THE LIVING NON-NEGROID PEOPLES OF NORTH AFRICA

(After Collignon ${ }^{3}$ )

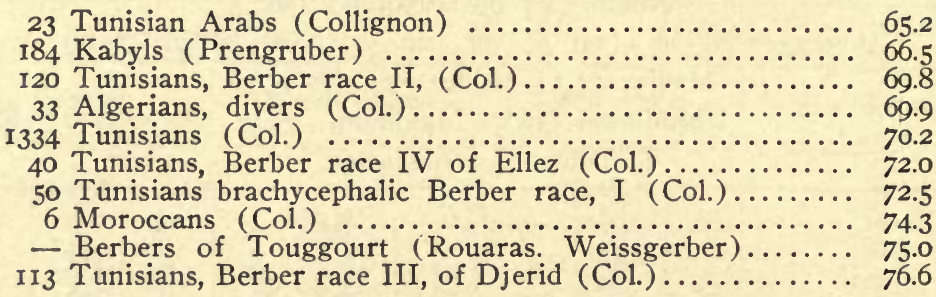

In whites (French, Mediterranean, Finns, Galtchas), as quoted by Collignon, the mean nasal index ranges from 63 to 69.4 , in Negroes, African and Oceanic, from 87.9 to 108.9. These data are not very extended, but suffice to show the position in respect to the nasal index of the Kharga Egyptians.

The range of variation of the nasal index in the Kharga men is large, reaching 38.4 points, which amounts to 0.25 for each unit of the average.

${ }^{1}$ Collignon, R.: La nomenclature quinaire de l'indice nasal du vivant, Rév. d'anthropol, $3^{\mathrm{m}}$ sér., II, I887, pp. 8-20. 
The distribution of the nasal index of the Kharga men is somewhat peculiar. The apex of the curve illustrating the same precedes unusually both the average and the median; following the apex the curve is shouldered, and finally it shows a smaller secondary grouping between 85.I and 87.5. It seems as if there were a tendency toward a double mode (at about 73.5 and 78 ) or even a triple mode $(+86)$. These features might be disregarded were it not for the fact that Myers, on the Valley Egyptians, obtained "in all the provinces which we chance to have examined frequency polygons showing one peak at 72 or $78 .{ }^{1}$ By mathematical considerations Myers ${ }^{2}$ is " forced to the conclusion that the coincident position of the peaks, in the various provinces which we have been considering, is a matter of pure accident, and that it is in no sense a proof of the presence of two or more distinct ethnic types, variously distributed in the different provinces of the country." 2 But to the present writer the accidental nature of the peculiarities of the distribution of the nasal index, both in the Valley and at the Oasis, is not so clearly demonstrated. However the case may be, the following facts are well established and should be borne in mind in this connection: The Egyptian, in the Valley or the Oasis, is fundamentally distinct by descent and in physical characteristics from the Nubian or Soudan negro; but he is now everywhere more or less mixed with the negro, and his nose, as well as hair, color, lips, and doubtless other features, have suffered accordingly; the nose of the Egyptian, as known from the crania, mummies, and the present more pure-blooded population, is mesorhinic, while that of the negro is platyrhinic, and an admixture of the negro would tend to augment the mesorhiny and cause the appearance, or make more frequent the appearance, of platyrhiny-as well shown by Myers on his "mixed" group and also in comparisons of the Copts and Mahommedans $;^{8}$ and the here enumerated effects can not but have influenced the averages of the nasal measurements and index, as well as their range and curves of distribution, in the present day Egyptian. Whether they are responsible for the double apex of the nasal index polygons in the Valley and for the peculiarities of that of the Oasis men can be better determined when we have more knowledge concerning the process of racial mixture and its effects, but the conditions of the case are such that consequences of that nature may be regarded as at least possible (fig. I2).

\footnotetext{
${ }^{1}$ L. c., Journ. Anthr. Inst., Vol. 36, I906, p. 246.

${ }^{2}$ Ibid., p. 255.

${ }^{3}$ Ibid., p. 263 et seq.
} 


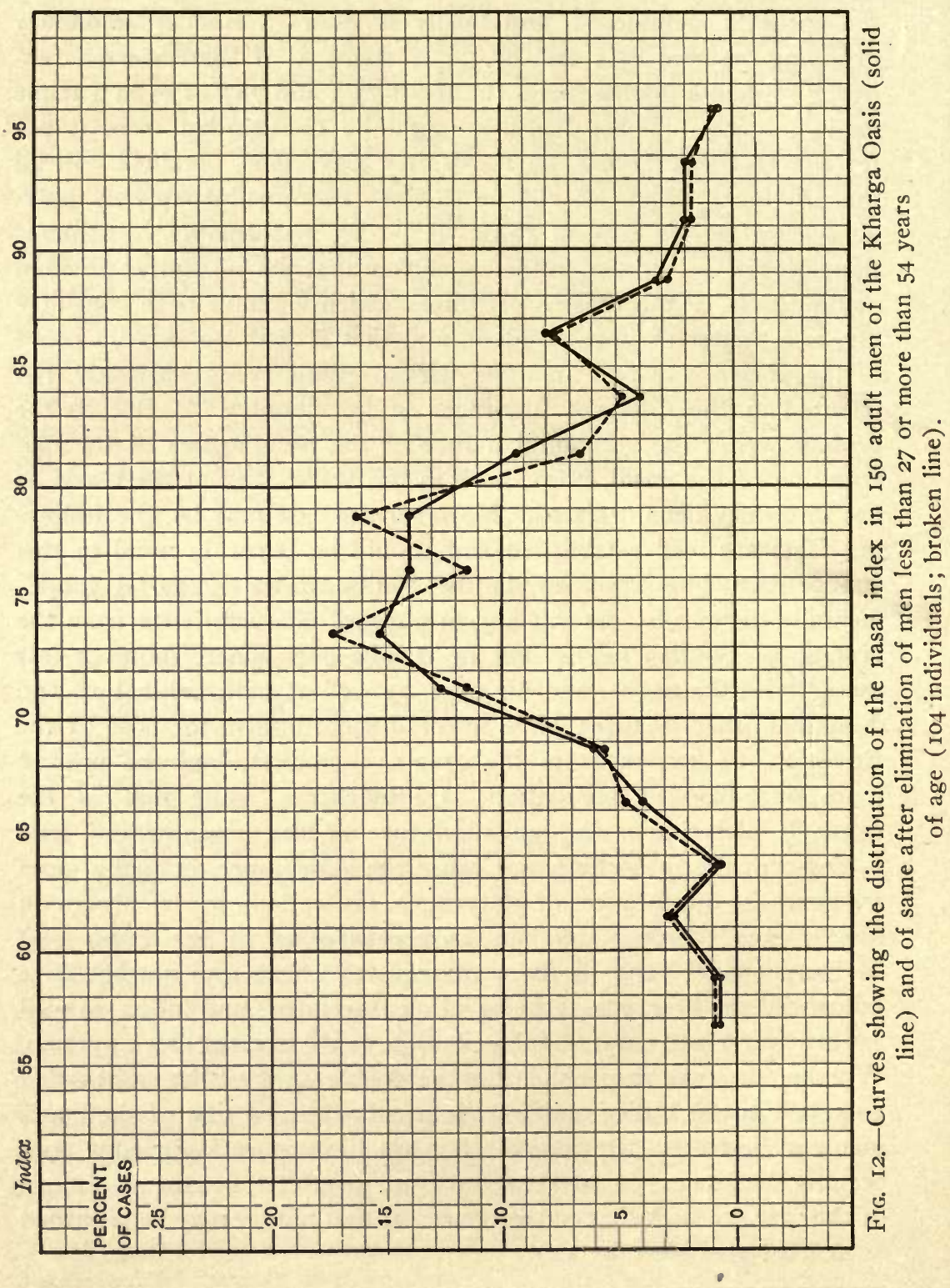


An inquiry as to the respective values of the two nasal measurements shows, as will be seen in the next table, in the thirteen cases with the lowest indices (av. 65.), that the height exceeds the average nasal height of the entire series in the proportion of 108 to I00, while the breadth stands to the general average nasal breadth in the Kharga men as 90 to 100 ; it is evident, therefore, that in leptorhiny, at Kharga, the nose is both higher and narrower, differing in both dimensions nearly alike from the general average. And an inquiry into the twelve cases with the highest nasal indices shows similar conditions, in a reversed way-the nose is both lower and broader and that by nearly the same proportion (height $=91.8$, breadth $=$ I09. I per cent) as the general averages of these dimensions.

KHARGA OASIS, MEN: DIMENSIONS OF THE NOSE IN CASES OF LOWEST AND THOSE OF HIGHEST NASAT INDEX

\begin{tabular}{l|l|l||l|l|l}
\hline \multicolumn{3}{c||}{ 13 lowest nasal indices } & \multicolumn{3}{c}{ I2 highest nasal indices } \\
\hline Index & Height of nose & Breadth of nose & Index & Height of nose & Breadth of nose \\
& & & & & \\
\hline 56.73 & 5.2 & 2.95 & 88.04 & 4.6 & 4.05 \\
60.00 & 5.0 & 3.0 & 88.24 & 5.1 & 4.5 \\
61.40 & 5.7 & 3.5 & 88.37 & 4.3 & 3.8 \\
61.82 & 5.5 & 3.4 & 88.89 & 4.5 & 4.0 \\
62.26 & 5.3 & 3.3 & 89.78 & 4.4 & 3.95 \\
62.50 & 5.2 & 3.25 & 90.70 & 4.3 & 3.9 \\
64.00 & 5.0 & 3.2 & 91.11 & 4.5 & 4.1 \\
65.45 & 5.5 & 3.6 & 92.31 & 4.55 & 4.2 \\
66.04 & 5.3 & 3.5 & 93.33 & 4.2 & 3.9 \\
66.35 & 5.2 & 3.45 & 92.86 & 4.5 & 4.2 \\
66.67 & 5.4 & 3.6 & 94.56 & 4.6 & 4.35 \\
66.67 & 5.4 & 3.6 & 95.12 & 4.1 & 3.9 \\
67.35 & 4.9 & 3.3 & & & \\
\hline
\end{tabular}

Averages:

\begin{tabular}{c|c|c|c|c|c}
\hline 63.63 & 5.28 & 3.36 & 91.03 & 4.47 & 4.07 \\
\hline Ratio of mean: & & & \\
\hline$\ldots$. & 108.3 & 90.0 & $\ldots .$. & 91.8 & 109.1 \\
\hline
\end{tabular}

The relations of the two nose measurements and of the nasal index to age, can not be discussed to best advantage with a series from which all senile subjects were excluded; nevertheless certain facts of interest are apparent. The following table gives the nasal dimensions and index in $2 \mathrm{I}$ youngest and 25 oldest men of the series. It is 
seen that both the nasal dimensions as well as the nasal index are higher in the old than in the young, though there are individual exceptions. The breadth has augmented more than the length, hence the higher index.

KHARGA OASIS, MEN: NASAL MEASUREMENTS AND INDEX IN RELATION TO AGE

\begin{tabular}{|c|c|c|c|c|c|c|c|}
\hline \multicolumn{4}{|c|}{$\begin{array}{l}21 \text { youngest individuals examined: } 21 \text { to } 26 \\
\text { years of age }\end{array}$} & \multicolumn{4}{|c|}{$\begin{array}{c}25 \text { oldest individuals examined: } 55 \text { to } 65 \\
\text { years of age }\end{array}$} \\
\hline $\begin{array}{l}\text { Approxi- } \\
\text { mate age } \\
\text { of subject }\end{array}$ & $\begin{array}{l}\text { Length of } \\
\text { nose }\end{array}$ & $\begin{array}{l}\text { Breadth of } \\
\text { nose }\end{array}$ & Nasal index & $\begin{array}{l}\text { Approxi- } \\
\text { mate age } \\
\text { of subject }\end{array}$ & $\begin{array}{l}\text { Length of } \\
\text { nose }\end{array}$ & $\begin{array}{l}\text { Breadth of } \\
\text { nose }\end{array}$ & Nasal index \\
\hline $\begin{array}{l}21 \\
22 \\
23 \\
23 \\
24 \\
24 \\
24 \\
24 \\
24 \\
24 \\
24 \\
24 \\
25 \\
25 \\
25 \\
25 \\
26 \\
26 \\
26 \\
26 \\
26\end{array}$ & $\begin{array}{l}4.5 \\
4.9 \\
4.9 \\
4.7 \\
5.0 \\
4.6 \\
4.8 \\
4.0 \\
4.7 \\
5.1 \\
4.8 \\
4.9 \\
4.6 \\
4.6 \\
4.8 \\
4.9 \\
5.0 \\
4.8 \\
4.4 \\
5.1 \\
4.8\end{array}$ & $\begin{array}{l}3.6 \\
3.8 \\
3.55 \\
3.25 \\
3.6 \\
3.7 \\
3.3 \\
3.5 \\
3.7 \\
3.6 \\
3.55 \\
3.7 \\
3.75 \\
3.65 \\
3.7 \\
3.8 \\
3.6 \\
3.7 \\
3.35 \\
3.45 \\
3.9\end{array}$ & $\begin{array}{l}80.00 \\
77.55 \\
72.45 \\
69.15 \\
72.00 \\
80.43 \\
68.75 \\
87.50 \\
78.72 \\
70.59 \\
73.96 \\
75.51 \\
81.52 \\
79.34 \\
77.08 \\
77.55 \\
72.00 \\
77.08 \\
76.13 \\
67.65 \\
81.25\end{array}$ & $\begin{array}{l}55 \\
55 \\
55 \\
55 \\
55 \\
55 \\
55 \\
55 \\
55 \\
55 \\
55 \\
55 \\
55 \\
55 \\
55 \\
55 \\
55 \\
55 \\
55 \\
58 \\
60 \\
60 \\
60 \\
60 \\
65\end{array}$ & $\begin{array}{l}5.0 \\
5.8 \\
5.15 \\
5.1 \\
5.0 \\
4.6 \\
4.55 \\
4.8 \\
4.7 \\
5.1 \\
5.6 \\
5.5 \\
4.4 \\
4.6 \\
4.6 \\
5.1 \\
4.9 \\
5.0 \\
4.6 \\
5.4 \\
5.1 \\
4.8 \\
5.0 \\
4.8 \\
5.0\end{array}$ & $\begin{array}{l}3.7 \\
4.2 \\
4.15 \\
3.7 \\
4.1 \\
4 \cdot 35 \\
4.2 \\
3.5 \\
4.1 \\
4.4 \\
4.0 \\
3.4 \\
3.8 \\
3.65 \\
3.5 \\
3.7 \\
3.95 \\
3.8 \\
4.05 \\
4.0 \\
4.5 \\
3.9 \\
4.15 \\
3.65 \\
3.4\end{array}$ & $\begin{array}{l}74.00 \\
72.41 \\
81.37 \\
72.55 \\
82.00 \\
94.57 \\
92.31 \\
72.92 \\
87.23 \\
86.27 \\
71.43 \\
61.82 \\
86.36 \\
79.35 \\
76.09 \\
72.55 \\
80.61 \\
76.00 \\
88.04 \\
74.07 \\
88.24 \\
81.25 \\
83.00 \\
76.04 \\
68.00\end{array}$ \\
\hline
\end{tabular}

Averages:

\begin{tabular}{|c|c|c|c|c|c|c|c|}
\hline 24.3 & $\begin{array}{c}4.76 \\
(4 \cdot 0-5 \cdot I)\end{array}$ & $\begin{array}{r}3.6 \\
(3.25- \\
3.9)\end{array}$ & $\begin{array}{c}75.8 \\
(67.6- \\
87.5)\end{array}$ & 56.4 & $\begin{array}{c}4.97 \\
(4.4-5.8)\end{array}$ & $\begin{array}{c}3.9 \\
(3.4-4.5)\end{array}$ & $\begin{array}{c}78.8 \\
(61.8- \\
94.6)\end{array}$ \\
\hline
\end{tabular}

The above comparison can be made still more complete by the inclusion of the measurements and index that correspond to the adults of mean age, or say those from 35 to 45 . The data are then as follows: 


\begin{tabular}{|c|c|c|c|c|c|c|}
\hline & $\begin{array}{c}\text { Mean } \\
\text { age }\end{array}$ & $\begin{array}{l}\text { Mean } \\
\text { nasal } \\
\text { length }\end{array}$ & $\begin{array}{c}\text { Percental } \\
\text { relation } \\
\text { to general } \\
\text { average } \\
\text { length }\end{array}$ & $\begin{array}{c}\text { Mean } \\
\text { nasal } \\
\text { breadth }\end{array}$ & $\begin{array}{c}\text { Percental } \\
\text { relation } \\
\text { to general } \\
\text { average } \\
\text { breadih }\end{array}$ & $\begin{array}{l}\text { Mean } \\
\text { nasal } \\
\text { index }\end{array}$ \\
\hline $\begin{array}{l}\text { The entire series of } 150 . . \\
\text { 2I youngest adults } \ldots . . . \\
42 \text { adults between } 35\end{array}$ & $\begin{array}{l}40.0 \\
24 \cdot 3\end{array}$ & $\begin{array}{l}4.87 \\
4 \cdot 76\end{array}$ & $\begin{array}{l}100 \\
97.7\end{array}$ & $\begin{array}{l}3.73 \\
3.6\end{array}$ & $\begin{array}{l}100 \\
96.5\end{array}$ & $\begin{array}{l}76.6 \\
75.8\end{array}$ \\
\hline $\begin{array}{l}\text { and } 45 \text { years of age. } \\
25 \text { oldest adults ......... }\end{array}$ & $\begin{array}{l}40.0 \\
56.4\end{array}$ & $\begin{array}{l}4.85 \\
4.97\end{array}$ & $\begin{array}{r}99.2 \\
102.1\end{array}$ & $\begin{array}{l}3.72 \\
3.9\end{array}$ & $\begin{array}{r}99.7 \\
104.6\end{array}$ & $\begin{array}{l}76.7 \\
78.8\end{array}$ \\
\hline
\end{tabular}

These figures show that the average nasal measurements and index in the adults in the "best" years agree very closely with the general averages of the entire series; and that both the measurements and the index are smaller in the youngest and larger in the oldest adults than in those of mean age or in the Kharga series as a whole. These conditions, notwithstanding individual exceptions and variations, are so regular and well marked that they can not be regarded as accidental. They bear evidence to the fact that in general the nose grows both in length and breadth even after a fully adult life is reached, apparently even after 45 years of age; they show that the growth is perceptibly greater in the breadth than in the length; and as a result of these alterations the mean nasal index increases with age, advancing towards platyrhiny. Judging from the writer's experiences with the Indian, the augmentation in length ceases somewhere before the age limit of the present series, and later on the dimension may diminish; but the breadth seems to increase slightly or retain its maximum proportions-unless affected by emaciation or pathological conditions, to the end of the life. A series of the oldest individuals in the Kharga Oasis would, it can be confidently expected, show a nasal index of still higher value than that shown by the group of the oldest men that were measured.

The differences in the mean nasal index in the youngest and that in the oldest men in the present series, suggested that the age factor might be responsible for what irregularities there were observed in the distribution of the index. But eliminating the "youngest" and "oldest" groups had actually the opposite effect, accentuating the main mode at $72.6-75$, as well as the tendency towards a second mode at $77.6-80$ and not influencing appreciably the third grouping at $85.1-87.5$. And the large variability of the series is not diminished. In this manner the curve of distribution of the index approaches that obtained by Myers in the Valley and the probability grows that the irregularity is due to admixture, which otherwise passed undetected at Kharga, of the platyrhinic Soudanese. 
KHARGA OASIS, MEN: NASAL INDEX IN ADULTS BETWEEN 27 AND 54 YEARS OF AGE

\begin{tabular}{|c|c|c|c|c|c|c|c|c|c|}
\hline & 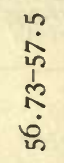 & $\begin{array}{l}8 \\
0 \\
0 \\
\text { in }\end{array}$ & $\begin{array}{l}\dot{n} \\
\dot{N} \\
\dot{1} \\
\ddot{8}\end{array}$ & $\begin{array}{l}\qquad 0 \\
0 \\
\text { லैं }\end{array}$ & $\begin{array}{l}\stackrel{2}{0} \\
\hat{0} \\
\stackrel{1}{0} \\
\dot{0}\end{array}$ & $\begin{array}{l}\stackrel{R}{1} \\
\hat{1} \\
\hat{0}\end{array}$ & $\begin{array}{l}\stackrel{2}{\stackrel{2}{*}} \\
\stackrel{1}{1} \\
\stackrel{2}{R}\end{array}$ & $\begin{array}{l}\mathfrak{n} \\
\text { b } \\
\text { i }\end{array}$ & 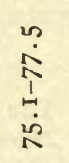 \\
\hline 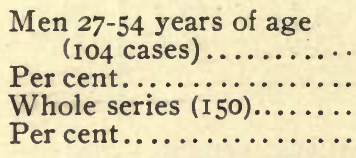 & $\begin{array}{c}\text { I } \\
1.0 \\
\text { I } \\
0.7\end{array}$ & $\begin{array}{c}\text { I } \\
1.0 \\
\text { I } \\
0.7\end{array}$ & $\begin{array}{c}3 \\
2.9 \\
4 \\
2.7\end{array}$ & $\begin{array}{c}\text { I } \\
1.0 \\
\text { I } \\
0.7\end{array}$ & $\begin{array}{c}5 \\
4.8 \\
6 \\
4.0\end{array}$ & $\begin{array}{c}6 \\
5.8 \\
9 \\
6.0\end{array}$ & $\begin{array}{c}12 \\
11.5 \\
19 \\
12.7\end{array}$ & $\begin{array}{c}18 \\
17.3 \\
23 \\
15.3\end{array}$ & $\begin{array}{c}\mathrm{I} 2 \\
11.5 \\
2 \mathrm{I} \\
14.0\end{array}$ \\
\hline
\end{tabular}

\begin{tabular}{|c|c|c|c|c|c|c|c|c|}
\hline & $\begin{array}{l}8 \\
1 \\
0 \\
i\end{array}$ & 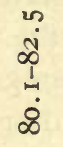 & $\begin{array}{l}20 \\
0 \\
0 \\
\infty \\
\infty\end{array}$ & $\begin{array}{l}\stackrel{n}{\hat{\infty}} \\
\infty \\
1 \\
\ddot{\infty} \\
\dot{\infty}\end{array}$ & $\begin{array}{l}8 \\
1 \\
1 \\
\infty \\
\infty\end{array}$ & 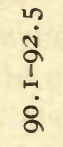 & $\begin{array}{l}n \\
0 \\
0 \\
\text { á }\end{array}$ & $\stackrel{\text { I }}{\stackrel{2}{2}}$ \\
\hline $\begin{array}{l}\text { Men } 27-54 \text { years of age } \\
\text { (I04 cases) } \ldots \ldots \ldots \ldots \ldots . . . .\end{array}$ & I7 & 7 & 5 & 8 & 3 & 2 & 2 & I \\
\hline 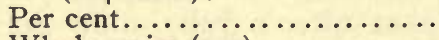 & 16.3 & 6.7 & 4.8 & 7.7 & 2.9 & 1.9 & 1.9 & 1.0 \\
\hline 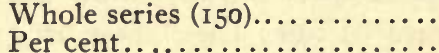 & $2 \mathrm{I}$ & I4 & 6 & 12 & 5 & 3 & 3 & $0_{0.7}^{\mathrm{I}}$ \\
\hline Per cent................... & 14.0 & 9.3 & 4.0 & 8.0 & 3.3 & 2.0 & 2.0 & 0.7 \\
\hline
\end{tabular}

It remains to inquire into the relations of the nasal index to that of the face, and to the cephalic index. In detail these relations appear as shown below.

The first important point observed is that low or high nasal indices are in adults, before senility becomes established, not due as a rule to excess or defect in one of the measurements from which the index is determined, but to concurrent and to a large extent correlative excess in one and defect in the other. Low nasal index, as has already been shown in other connections, goes with a greater than average height and a subaverage breadth of the organ, while high index is conditioned by a less than average height and greater than average breadth of the nose. And in both categories of cases, that is, in low as well as high nasal indices, the differences in the measurements from the general mean of the same dimensions are quite alike for the length and the breadth. Thus in the group of the lowest nasal indices the height of the nose stands to the general average of the measurement in the Kharga series $(4.87 \mathrm{~cm}$.) in round figures as 107 to 100 , or +7 , and the breadth as 92 to 100 , or -8 ; while in the group of the highest indices, similar proportions are respectively 92 , or -8 , and 108 , or +8 , to 100 . 
KHARGA OASIS, MEN: RELATION OF THE NASAI INDEX TO NASAI HEIGHT AND BREADTH, TO FACIAT HEIGHT, BREADTH AND INDEX, AND TO CEPHALIC INDEX

20 Lowest Nasal Indices; below 68.0

\begin{tabular}{|c|c|c|c|c|c|c|}
\hline $\begin{array}{c}\text { Nasal } \\
\text { index }\end{array}$ & $\begin{array}{l}\text { Nasal } \\
\text { height }\end{array}$ & $\begin{array}{c}\text { Nasal } \\
\text { breadth }\end{array}$ & $\begin{array}{l}\text { Height of } \\
\text { the face }\end{array}$ & $\begin{array}{l}\text { Breadth of } \\
\text { the face }\end{array}$ & $\begin{array}{l}\text { Facial } \\
\text { index }\end{array}$ & $\begin{array}{l}\text { Cephalic } \\
\text { index }\end{array}$ \\
\hline 56.7 & 5.2 & 2.95 & I2.3 & I3.2 & 93.2 & $75 \cdot 3$ \\
\hline 60.0 & $5.0^{\circ}$ & 3.0 & II.9 & 13.2 & 90.1 & 73.8 \\
\hline $6 \mathrm{I} \cdot 4$ & $5 \cdot 7$ & $3 \cdot 5$ & I3.9 & 14.0 & 99.3 & 74.6 \\
\hline 61.8 & $5 \cdot 5$ & 3.4 & II. 5 & $13 \cdot 3$ & 86.5 & 79.5 \\
\hline $62 \cdot 3$ & 53 & $3 \cdot 3$ & 10.9 & 12.5 & 87.2 & $75 \cdot 5$ \\
\hline 62.5 & 5.2 & 325 & II. 5 & I3.I & 87.8 & 75.8 \\
\hline 64.0 & 5.0 & 3.2 & II .8 & 13.0 & 90.8 & 75.4 \\
\hline 65.5 & $5 \cdot 5$ & 3.6 & 12.7 & I3.4 & 94.8 & 76.1 \\
\hline 66.0 & $5 \cdot 3$ & 3.5 & II. 5 & I3.2 & 87.1 & 77.9 \\
\hline $66 \cdot 3$ & 5.2 & 3.45 & II.7 & 12.7 & 92.1 & $73 \cdot 3$ \\
\hline 66.7 & $5 \cdot 4$ & 3.6 & 12.0 & I3.4 & $89 \cdot 5$ & 79.8 \\
\hline 66.7 & $5 \cdot 4$ & 3.6 & II.9 & I3. 4 & 88.8 & 76.1 \\
\hline 63.7 & $4 \cdot 9$ & $3 \cdot 3$ & II $\cdot 5$ & I2.6 & 91.3 & 68.2 \\
\hline 676 & $5 . I$ & 3.45 & I I. 2 & I2.9 & 86.8 & $71: 8$ \\
\hline 68.0 & 5.0 & $3 \cdot 4$ & II .8 & 12.9 & 91.5 & 77.4 \\
\hline 68.0 & 5.0 & 3.4 & II. 2 & I 3.2 & 84.8 & 716 \\
\hline 68.3 & 5.2 & 3.55 & II.4 & 13.0 & 87.7 & 74.2 \\
\hline 68.7 & 4.8 & $3 \cdot 3$ & II.O & I3.0 & 84.6 & 73.5 \\
\hline 69.1 & $4 \cdot 7$ & 3.25 & 10.9 & II. 8 & 92.4 & 78.6 \\
\hline 69.1 & $5 \cdot 5$ & 3.8 & I2.I & I3.5 & 89.6 & $74 \cdot 7$ \\
\hline
\end{tabular}

Averages:

\begin{tabular}{|c|c|c|c|c|c|c|}
\hline 65.4 & 5.2 & 3.4 & 11.7 & 13.1 & 89.8 & 75.2 \\
$(56.7-$ & $(4.7-$ & $(2.95-$ & $(10.9-$ & $(11.8-$ & $(84.6-$ & $(68.2-$ \\
$69.1)$ & $5.8)$ & $3.8)$ & 13.9) & 14.0) & $99.3)$ & $79.8)$ \\
\hline
\end{tabular}

21 Highest Nasal Indices, 84.0 and above

\begin{tabular}{|c|c|c|c|c|c|c|}
\hline $\begin{array}{l}\text { Nasal } \\
\text { index }\end{array}$ & $\begin{array}{l}\text { - Nasal } \\
\text { height }\end{array}$ & $\begin{array}{c}\text { Nasal } \\
\text { breadth }\end{array}$ & $\begin{array}{l}\text { Height of } \\
\text { the face }\end{array}$ & $\begin{array}{c}\text { Breadth of } \\
\text { the face }\end{array}$ & $\begin{array}{l}\text { Facial } \\
\text { index }\end{array}$ & $\begin{array}{c}\text { Cephalic } \\
\text { index }\end{array}$ \\
\hline 86.4 & 4.4 & 3.8 & 10.8 & 12.7 & 85.0 & $77 \cdot 5$ \\
\hline 86.4 & 4.4 & 3.8 & 12.0 & 13.4 & 89.5 & 71.6 \\
\hline $86 \cdot 3$ & 5.1 & 4.4 & 12.0 & I3.2 & 90.9 & 78.5 \\
\hline 86.7 & $4 \cdot 5$ & 3.9 & 10.6 & 12.6 & 84.9 & 75.0 \\
\hline 86.9 & 4.2 & 3.65 & 10.7 & 12.6 & $84 . I$ & 70.2 \\
\hline 87.0 & 4.6 & 4.0 & 10.9 & I3.3 & 81.9 & 74.7 \\
\hline 87.0 & 4.6 & 4.0 & II.O & I3.I & 84.0 & 72.7 \\
\hline 87.2 & 4.7 & $4 . I$ & 10.9 & 13.6 & 80 I & 73.2 \\
\hline 87.5 & 4.0 & $3 \cdot 5$ & 10.4 & I3. I & 79.4 & 75.0 \\
\hline 88.0 & 4.6 & 4.05 & 10.6 & 13.2 & 80.3 & $75 \cdot 3$ \\
\hline 88.2 & $5 \cdot I$ & $4 \cdot 5$ & 12.0 & I3. I & 77.1 & 76.4 \\
\hline 88.4 & $4 \cdot 3$ & 3.8 & 10.8 & 14.0 & 91.6 & 75.1 \\
\hline 88.9 & $4 \cdot 5$ & 4.0 & 10.5 & 12.8 & 82.0 & $79 \cdot 4$ \\
\hline 89.8 & 4.4 & 3.95 & 10.6 & 12.9 & 82.2 & 74.2 \\
\hline 90.7 & $4 \cdot 3$ & 3.9 & II . 2 & 13.3 & 84.2 & 77.6 \\
\hline 9I.I & 4.5 & $4 . I$ & II.I & 13.3 & $83 \cdot 5$ & 72.4 \\
\hline 92.3 & 4.55 & 4.2 & II. 5 & 12.9 & $89 . \mathrm{I}$ & 73.0 \\
\hline 92.9 & 4.2 & 3.9 & 9.8 & 12.6 & 77.8 & 77.1 \\
\hline 93.3 & 4.5 & 4.2 & 10.5 & I 3.2 & 79.5 & 72.4 \\
\hline 94.6 & 4.6 & $4 \cdot 35$ & 10.7 & 13.2 & $8 \mathrm{I} \cdot \mathrm{I}$ & 71.3 \\
\hline 95.1 & $4 \cdot I$ & $3 \cdot 9$ & 10.8 & I2.0 & 90.0 & 70.7 \\
\hline \multicolumn{7}{|c|}{ Averages: } \\
\hline $\begin{array}{c}88.9 \\
\left(86.4^{-}\right. \\
95.1)\end{array}$ & $\begin{array}{r}4.5 \\
(4.0- \\
5.1)\end{array}$ & $\begin{array}{c}4.0 \\
(3.5- \\
4.5)\end{array}$ & $\begin{array}{c}10.9 \\
\left(10.4^{-}\right. \\
12.0)\end{array}$ & $\begin{array}{c}13.1 \\
(12.6- \\
14.0)\end{array}$ & $\begin{array}{l}83.7 \\
(77.1- \\
91.6)\end{array}$ & $\begin{array}{c}74.4 \\
(70.2- \\
79.4)\end{array}$ \\
\hline
\end{tabular}


The influence of the facial height on the nose is again seen to be pronounced. It affects primarily the nasal height, secondarily the nasal index. The higher the face, the higher, as a rule, the nose and the lower the nasal index; and vice versa.

The breadth of the face, notwithstanding the correlation with it of the nasal breadth, evidently influences the facial index only secondarily and very irregularly. This is unexpected, but so far as this particular ethnic group is concerned, the lack of correspondence, at least for the cases with the lowest and the highest nasal indices, is very plain.

As to the relation of the nasal with the cephalic index in the Kharga men, the results are negative. It is seen in the two groups representing the extremes of the nasal index that not only the mean corresponding cephalic index but even the range of variation are quite alike.

\section{SECONDARY FACIAL MEASUREMENTS}

\section{Diameter Frontal Minimum}

The smallest frontal breadth, determined in Ioo of the Kharga men, averages $10.26 \mathrm{~cm}$., and varies to the moderate extent of 18 $\mathrm{mm}$. or \pm 0.087 per unit of the average. The distribution of the measurement is fairly regular. Its anthropological value is not great.

KHARGA OASIS, MEN: DIAMETER FRONTAL MINIMUM

Number of individuals measured: 100.

Average: $10.26 \mathrm{~cm}$. (Ist $50: 10.3 ; 2 \mathrm{~d} 50: 10.2 \mathrm{~cm}$.)

Median: $10.2 \mathrm{~cm}$. Mode: $10.2 \mathrm{~cm}$.

Minimum: $9.4 \mathrm{~cm}$. Maximum: $I I .2 \mathrm{~cm}$.

Table of frequencies:

\begin{tabular}{|c|c|c|c|c|c|c|c|c|c|}
\hline t & 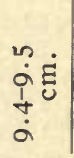 & $\begin{array}{l}\hat{0} \dot{\Xi} \\
\hat{i} \\
\dot{a}\end{array}$ & $\begin{array}{l}a \\
\dot{j} \\
\infty \\
0 \\
\dot{a}\end{array}$ & $\begin{array}{l}\dddot{0} \\
\stackrel{0}{1} \\
0 \\
\dot{0} \\
\dot{0}\end{array}$ & 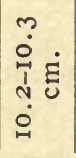 & 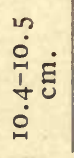 & $\begin{array}{l}\hat{0} \\
\dot{0} \\
\hat{\jmath} \\
\dot{\Xi} \\
\dot{0}\end{array}$ & $\begin{array}{c}0 \\
\dot{0} \\
0 \\
1 \\
\infty \\
\dot{E} \\
\dot{0} \\
0\end{array}$ & 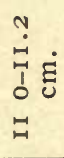 \\
\hline $\begin{array}{l}\text { Number and per cent } \\
\text { of cases............. }\end{array}$ & 3 & 5 & 11 & 18 & 23 & 15 & 16 & 8 & 1 \\
\hline
\end{tabular}

The correlations of the smallest frontal breadth with the greatest breadth of the head and that of the face are shown in the next table. A broader forehead is seen to correspond in general to a broader head as well as face; but on the average the breadth of the forehead increases in this series at a more rapid rate than either of the dimensions with which it is compared. 
KHARGA OASIS, MEN: RELATION OF DIAMETER FRONTAI MINIMUM TO BREADTH OF FACE AND BREADTH OF HEAD

\begin{tabular}{|c|c|c|c|c|c|}
\hline \multicolumn{3}{|c|}{$\begin{array}{l}19 \text { narrowest foreheads: } \\
\text { less than } 10.0 \mathrm{~cm} \text {. }\end{array}$} & \multicolumn{3}{|c|}{$\begin{array}{l}\text { I9 broadest foreheads: } \\
\text { 10.7 } \mathrm{cm} \text {. and above }\end{array}$} \\
\hline $\begin{array}{l}\text { Diameter } \\
\text { frontal } \\
\text { minimum }\end{array}$ & $\begin{array}{c}\text { Diameter } \\
\text { bizygomatic } \\
\text { maximum }\end{array}$ & $\begin{array}{l}\text { Greatest } \\
\text { breadth } \\
\text { of head }\end{array}$ & $\begin{array}{l}\text { Diameter } \\
\text { frontal } \\
\text { minimum }\end{array}$ & $\begin{array}{l}\text { Diameter } \\
\text { bizygomatic } \\
\text { maximum }\end{array}$ & $\begin{array}{l}\text { Greatest } \\
\text { breadth } \\
\text { of head }\end{array}$ \\
\hline $\mathrm{cm}$ & $\mathrm{cm}$. & $\mathrm{cm}$. & $\mathrm{cm}$. & $\mathrm{cm}$. & $\mathrm{cm}$ \\
\hline $9 \cdot 4$ & I $2 . \mathrm{I}$ & I3.0 & 10.7 & 13.6 & 14.6 \\
\hline $9 \cdot 4$ & I3. 7 & I 4.1 & 10.7 & I2.9 & $\mathrm{I} 4.2$ \\
\hline 94 & 13.8 & I 4.4 & I0 7 & I3. 4 & I4. I \\
\hline 9.6 & 12.8 & $13 \cdot 4$ & 10.7 & I3 6 & I3.9 \\
\hline 9.6 & 12.0 & 13.2 & 10.7 & I 3.4 & I 5.0 \\
\hline 9.7 & 12.9 & I3 8 & I 0.7 & I3. 4 & I 4.2 \\
\hline 9.7 & I $3 \cdot 3$ & I 4.0 & 10. 7 & $13 \cdot 3$ & I3.9 \\
\hline 9.7 & 126 & I3.8 & 10.7 & I3. I & 14.4 \\
\hline 9.8 & 13.0 & I 4.4 & 10.7 & I3. I & 14.2 \\
\hline 9.8 & 132 & $13 \cdot 4$ & 10.7 & I3.9 & $14 \cdot 3$ \\
\hline 9.8 & I3.8 & I 3.4 & I0. 8 & I 2.8 & I 4.7 \\
\hline 9.8 & I3.0 & I3. 3 & I0. 8 & I3.9 & I4. I \\
\hline 9.8 & I 3.8 & 14.2 & 10.8 & 13.4 & 14.0 \\
\hline 9.8 & I2. 6 & 14.0 & I0.8 & I2.9 & I3. 4 \\
\hline 9.8 & 125 & I3.6 & I0.9 & I 3.0 & I4.0 \\
\hline 9.9 & 12.5 & I3.9 & 10.9 & 13.7 & 14.2 \\
\hline 9.9 & 12.6 & I 4.8 & 10.9 & I 3.2 & I 4.4 \\
\hline 99 & I3.0 & 14.5 & 10.9 & I3.6 & 14.6 \\
\hline 99 & I3. I & 13.9 & II. 2 & I3. 4 & I $4 \cdot 3$ \\
\hline
\end{tabular}

Averages :

\begin{tabular}{c|c|c||c|c|c}
9.7 & 13.0 & 13.8 & 10.8 & 13.35 & 14.2 \\
$(9.4-9.9)$ & $(12.0-13.8)$ & $(\mathrm{I} 3.0-14.8)$ & $(\mathrm{IO} .7-\mathrm{II} .2)$ & $(\mathrm{I} 2.8-\mathrm{I} 3.9)$ & $(\mathrm{I} 3.4-\mathrm{I} 5.0)$ \\
\hline
\end{tabular}

Per cent :

\begin{tabular}{|c|c|c|c|c|c|}
\hline 100 & 74.6 & 703 & 100 & 80.9 & 76.1 \\
\hline \multicolumn{4}{|c|}{$\begin{array}{l}\text { Averages and per cent that would exist if the rela- } \\
\text { tion of the measurements were the same as in the } \\
\text { group with lowest foreheads. }\end{array}$} & $\begin{array}{l}(14.5) \\
(83.1)\end{array}$ & $\begin{array}{l}(15.4) \\
(78.3)\end{array}$ \\
\hline
\end{tabular}

\section{Width of the Mouth ${ }^{1}$}

One hundred observations on the Kharga men concerning this feature give the average of $5.4 \mathrm{~cm}$., representing a medium dimension. The range of variation is not very large, extending over I 3 $\mathrm{mm}$. which represents \pm 0.12 per unit of the average. The distribution is regular.

${ }^{1}$ Between the extremities of the oral fissure with the mouth closed and face at rest. 
KHARGA OASIS, MEN: WIDTH OF THE MOUTH

Number of individuals measured: 100 .

Average: $5.4 \mathrm{~cm}$. (Ist $50: 5.4 ; 2 \mathrm{~d} 50: 5.4 \mathrm{~cm}$.)

Median : $5.4 \mathrm{~cm}$. Mode: $5.3 \mathrm{~cm}$.

Minimum : $4.7 \mathrm{~cm}$. Maximum: $6.0 \mathrm{~cm}$.

\begin{tabular}{|c|c|c|c|c|c|c|c|c|}
\hline & $\begin{array}{l}\dot{E} \\
\tilde{Z} \\
\dot{\nabla}\end{array}$ & $\begin{array}{l}\dot{E} \\
\text { U } \\
0 \\
\dot{\sigma} \\
\infty \\
\dot{\sigma} \\
\dot{\sigma}\end{array}$ & $\begin{array}{l}\dot{E} \\
\text { U } \\
\text { ம் } \\
\dot{0} \\
\dot{0}\end{array}$ & 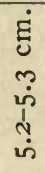 & $\begin{array}{l}\dot{E} \\
\text { ப́ } \\
\text { in } \\
\dot{\varphi} \\
\stackrel{1}{+} \\
\text { in }\end{array}$ & $\begin{array}{l}\dot{E} \\
\text { Uं } \\
\hat{p} \\
\dot{\rho} \\
\dot{b}\end{array}$ & 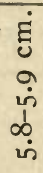 & $\begin{array}{l}\dot{E} \\
\dot{0} \\
\dot{0}\end{array}$ \\
\hline Number and per cent of cases. & 3 & 5 & 15 & 18 & 21 & 18 & 16 & 4 \\
\hline
\end{tabular}

The breadth of the mouth, as will be more clearly seen from the succeeding figures, bears to some extent a direct relation with the breadth of the nose, the breadth of the face and especially with age.

KHARGA OASIS, MEN: RELATION OF WIDTH OF MOUTH TO BREADTH OF FACE, BREADTH OF NOSE, AND TO AGE

\begin{tabular}{|c|c|c|c|c|c|c|c|}
\hline \multicolumn{4}{|c|}{23 narrowest mouths: $5.1 \mathrm{~cm}$. and less } & \multicolumn{4}{|c|}{20 widest mouths: $5.8 \mathrm{~cm}$. and more } \\
\hline $\begin{array}{l}\text { Width of } \\
\text { mouth }\end{array}$ & $\begin{array}{c}\text { Breadth of } \\
\text { face }\end{array}$ & $\begin{array}{c}\text { Breadth of } \\
\text { nose }\end{array}$ & $\begin{array}{c}\text { Age of } \\
\text { ndividual }\end{array}$ & $\begin{array}{l}\text { Width of } \\
\text { mouth }\end{array}$ & $\begin{array}{l}\text { Breadth of } \\
\text { face }\end{array}$ & $\begin{array}{c}\text { Breadth of } \\
\text { nose }\end{array}$ & $\begin{array}{c}\text { Age of } \\
\text { individual }\end{array}$ \\
\hline $\begin{array}{l}\mathrm{cm} . \\
4.7 \\
4.7 \\
4.7 \\
4.8 \\
4.8 \\
4.9 \\
4.9 \\
4.9 \\
5.0 \\
5.0 \\
5.0 \\
5.0 \\
5.0 \\
5.0 \\
5.1 \\
5.1 \\
5.1 \\
5.1 \\
5.1 \\
5.1 \\
5.1 \\
5.1 \\
5.1\end{array}$ & $\begin{array}{l}\text { cm. } \\
12.9 \\
\text { I3.0 } \\
12.9 \\
11.8 \\
13.0 \\
12.9 \\
13.2 \\
13.1 \\
12.5 \\
12.9 \\
13.2 \\
13.8 \\
13.4 \\
13.4 \\
12.9 \\
13.4 \\
13.4 \\
13.0 \\
\text { I3.0 } \\
\text { I3.I } \\
\text { I2.9 } \\
\text { I3.2 } \\
\text { I3.3 }\end{array}$ & $\begin{array}{l}\mathrm{cm} . \\
3.4 \\
3.8 \\
3.35 \\
3.25 \\
3.3 \\
3.65 \\
3.55 \\
3.5 \\
3.65 \\
4.0 \\
3.7 \\
3.8 \\
3.55 \\
3.7 \\
3.5 \\
3.9 \\
3.7 \\
4.0 \\
3.7 \\
3.7 \\
3.45 \\
3.5 \\
3.55\end{array}$ & $\begin{array}{c}\text { Years } \\
36 \\
38 \\
26 \\
23 \\
24 \\
25 \\
32 \\
24 \\
45 \\
28 \\
24 \\
50 \\
28 \\
55 \\
35 \\
60 \\
30 \\
48 \\
38 \\
24 \\
26 \\
28 \\
54\end{array}$ & $\begin{array}{l}\mathrm{cm} . \\
5.8 \\
5.8 \\
5.8 \\
5.8 \\
5.8 \\
5.8 \\
5.8 \\
5.8 \\
5.8 \\
5.9 \\
5.9 \\
5.9 \\
5.9 \\
5.9 \\
5.9 \\
5.9 \\
6.0 \\
6.0 \\
6.0 \\
6.0\end{array}$ & $\begin{array}{c}\mathrm{cm} . \\
\text { I3.0 } \\
\text { I3.0 } \\
13.5 \\
13.9 \\
13.7 \\
12.9 \\
12.0 \\
13.0 \\
13.9 \\
13.6 \\
12.8 \\
13.6 \\
\text { I3.8 } \\
\text { I3.1 } \\
\text { I3.6 } \\
\text { I2.9 } \\
\text { I3.2 } \\
\text { I3.2 } \\
\text { 13.6 } \\
\text { 13.9 }\end{array}$ & $\begin{array}{l}\mathrm{cm} . \\
3.6 \\
3.6 \\
3.9 \\
3.65 \\
3.8 \\
4.0 \\
3.9 \\
3.8 \\
3.65 \\
3.6 \\
3.6 \\
3.2 \\
4.15 \\
4.0 \\
4.1 \\
4.0 \\
4.1 \\
4.35 \\
4.1 \\
3.8\end{array}$ & $\begin{array}{c}\text { Years } \\
24 \\
26 \\
40 \\
45 \\
40 \\
58 \\
40 \\
50 \\
48 \\
27 \\
50 \\
40 \\
50 \\
50 \\
55 \\
55 \\
40 \\
55 \\
50 \\
50\end{array}$ \\
\hline \multicolumn{8}{|c|}{ Averages: } \\
\hline 5.0 & $\begin{array}{l}13.05 \\
(11.8- \\
13.8)\end{array}$ & $\begin{array}{c}3.6 \\
(3.25- \\
4.0)\end{array}$ & $\begin{array}{c}35 \\
(23-60)\end{array}$ & 5.9 & $\begin{array}{c}13.3 \\
(12.0- \\
13.9)\end{array}$ & $\begin{array}{c}3.85 \\
(3.2- \\
4.35)\end{array}$ & $\begin{array}{c}44 \\
(24-58)\end{array}$ \\
\hline
\end{tabular}


The older adults at Kharga have in general broader mouths than the young adults, and a correspondence is frequently noticeable between broad noses and faces and broad mouths. The nose and mouth influence each other probably but very little, if at all, but both are affected alike by age and breadth of face.

\section{The Bigonial Diameter of the Lower Jaw}

The greatest lower facial breadth, or diameter bigonial, presents in the Kharga men the very moderate average of $10.3 \mathrm{~cm}$. Weisbach ${ }^{1}$ obtained in the Patagonians 13.0; Australians II.5; Maori I I.4; northern Slavs and Roumanians II.3; Tagalogs II.I ; southern Chinese, Magyars II.o; Javanese I0.9; Gypsies Io.8; Hawaiians I0.7; Jews Io.6; Siamese, northern Chinese, Congo negroes I0.4; Japanese I0.2; Kaffirs IO.I; and Hottentots $9.2 \mathrm{~cm}$.

The range of variation of the measurement in the Kharga series is $3.2 \mathrm{~cm}$., equalling \pm 0.156 per unit of the average, which is not above the ordinary. The distribution of the measurement is somewhat irregular, which is doubtless due to functional causes, or more directly, to uneven development of the masseters.

KHARGA OASIS, MEN: DIAMETER BIGONIAL OF LOWER JAW

Number of individuals measured: IoO.

Average: $10.3 \mathrm{~cm}$. (Ist $50: 10.4 ; 2 \mathrm{~d} 50: 10.2 \mathrm{~cm}$.)

Median : $10.4 \mathrm{~cm}$. Modes: Io and $10.6 \mathrm{~cm}$.

Minimum : $8.9 \mathrm{~cm}$. Maximum: $I 2 . I \mathrm{~cm}$.

Table of frequencies:

\begin{tabular}{|c|c|c|c|c|c|c|c|c|c|c|c|c|c|}
\hline & $\begin{array}{l}\text { E् } \\
0 \\
9 \\
0 \\
\infty\end{array}$ & 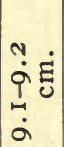 & $\begin{array}{l}+\dot{d} \\
\dot{9} \\
\text { du } \\
\dot{a}\end{array}$ & $\begin{array}{l}0 \\
\dot{9} \\
\dot{1} \\
\text { బै } \\
\dot{0}\end{array}$ & 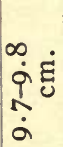 & $\begin{array}{l}\text { 엄 } \\
\grave{a} \\
\dot{a} \\
\dot{a}\end{array}$ & \begin{tabular}{l}
$\sim$ \\
0 \\
0 \\
1 \\
1 \\
\hdashline \\
\hdashline \\
0 \\
0 \\
0
\end{tabular} & $\begin{array}{l}+ \\
\dot{0} \\
0 \\
1 \\
m \\
\dot{m} \\
0 \\
0 \\
0\end{array}$ & 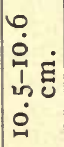 & $\begin{array}{l}\infty \\
0 \\
0 \\
1 \\
\\
\\
\dot{0} \\
0\end{array}$ & 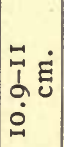 & 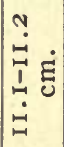 & 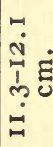 \\
\hline $\begin{array}{l}\text { Number and per } \\
\text { cent of cases }\end{array}$ & 1 & 3 & 3 & 6 & 8 & 12 & 11 & 10 & 19 & 13 & 6 & 5 & 3 \\
\hline
\end{tabular}

The bigonial diameter bears a direct relation with the greatest breadth of the face and an indirect one with that of the head. But, as in the case of the breadth of the forehead, the dimension augments within the series at a greater rate than those with which it is compared, in other words it is enlarged to some extent through other agencies than the correlation with the breadth of the upper face

${ }^{1}$ L. c., pp. $279-280$. 
and the more distinct one with the head. These conditions are seen clearly in the following table.

The increase of the measurement with the increase in the breadth of the head is due on one hand to the correlation with the latter of the breadth of the upper face, which in turn influences the lower jaw; and on the other to the effect of the broad base of such a skull on the condyles and the ascending rami of the lower jaw. Broadening of the bigonial diameter independent of these factors is due almost entirely to the action of the masseters, which in some instances results in a marked eversion of the lower portion of the jaw at the angle.

KHARGA OASIS, MEN: RELATION OF DIAMETER BIGONIAL TO BREADTH OF FACE AND BREADTH OF HEAD

\begin{tabular}{|c|c|c|c|c|c|}
\hline \multicolumn{3}{|c|}{$\begin{array}{l}\text { I7 narrowest jaws: } \\
9.7 \mathrm{~cm} \text {. and below }\end{array}$} & \multicolumn{3}{|c|}{$\begin{array}{l}14 \text { broadest jaws: } \\
10.9 \mathrm{~cm} \text {. and above }\end{array}$} \\
\hline $\begin{array}{l}\text { Diameter } \\
\text { bigonial }\end{array}$ & $\begin{array}{c}\text { Diameter } \\
\text { bizygomatic } \\
\text { maximum }\end{array}$ & $\begin{array}{l}\text { Greatest } \\
\text { breadth } \\
\text { of head }\end{array}$ & $\begin{array}{l}\text { Diameter } \\
\text { bigonial }\end{array}$ & $\begin{array}{l}\text { Diameter } \\
\text { bizygomatic } \\
\text { maximum }\end{array}$ & $\begin{array}{l}\text { Greatest } \\
\text { breadth } \\
\text { of head }\end{array}$ \\
\hline cin. & $\mathrm{cm}$. & $c m$. & $\mathrm{cm}$ & $\mathrm{cm}$. & $c m$. \\
\hline 8.9 & I2.I & 13.0 & 10.9 & I3 5 & I 4.2 \\
\hline 9. I & 12.6 & I 4.8 & 10.9 & I3.I & I 4.4 \\
\hline 9.I & I 1.8 & I 4.0 & I0.9 & I3.0 & 14.5 \\
\hline 9.2 & 12.8 & 14.7 & 10.9 & 13.4 & 14.4 \\
\hline 9.3 & 13.0 & 14.0 & I I.O & I 3.8 & 14.2 \\
\hline 9.3 & I 3.4 & 14.2 & I I.O & 13.9 & $\mathrm{I} 4.4$ \\
\hline 9.4 & 13.2 & I3.9 & II. I & I 3.7 & 14.2 \\
\hline 9.5 & 13.0 & I 3.3 & II.I & I 3.5 & 14.4 \\
\hline 9.5 & 12.9 & I 3.4 & I I. I & I 3.4 & 13.7 \\
\hline 9.5 & I3. I & I 3.9 & I I. 2 & I3.8 & 13.4 \\
\hline 9.6. & 12.8 & I 3.4 & II. 2 & I 2.6 & I 3.8 \\
\hline 9.6 & I 2.9 & I3.8 & II.4 & I3.6 & 13.9 \\
\hline 9.6 & 12.0 & 13.2 & I I. 8 & I 3.2 & I 4.6 \\
\hline 9.7 & 12.9 & 13.6 & I2.I & I3.6 & 14.6 \\
\hline 9.7 & I3.I & I3.6 & & & \\
\hline 9.7 & I3.6 & I 4.2 & & & \\
\hline 9.7 & 13.3 & 13.6 & & & \\
\hline
\end{tabular}

Averages :

\begin{tabular}{|c|c|c|c|c|c|}
\hline$(8 \stackrel{9.4}{9-9 \cdot 7})$ & $\begin{array}{c}12.85 \\
(11.8-13.6)\end{array}$ & $\begin{array}{c}13.8 \\
(13 \cdot 0-14 \cdot 8)\end{array}$ & $\begin{array}{c}11.2 \\
(10.9-12.1)\end{array}$ & $\begin{array}{c}13.4 \\
(12.6-13.9)\end{array}$ & $\begin{array}{c}14.2 \\
(13 \cdot 4-14.6)\end{array}$ \\
\hline
\end{tabular}

Per cent :

\begin{tabular}{|c|c|c|c|c|c|}
\hline 100 & 73.1 & 68.1 & 100 & 83.6 & 78.9 \\
\hline \multicolumn{4}{|c|}{$\begin{array}{l}\text { Averages and per cent that would exist if the rela- } \\
\text { tion of the measurements were the same as in the } \\
\text { group with narrowest jaws. }\end{array}$} & $\left(\begin{array}{l}15.3 \\
87.1\end{array}\right)$ & $\begin{array}{l}(\mathrm{r} 6.4) \\
(81.1)\end{array}$ \\
\hline
\end{tabular}




\section{The Ears}

The dimensions of the ears possess certain anthropological value; the small ear of the negro is clearly separable from the larger one of the white, and there are probably other racial differences.

The writer measures invariably the left ear, which to a righthand observer is more easily approachable with the instruments than that on the opposite side, and the measurements taken are the maximum height and the maximum breadth. ${ }^{1}$

The average height of the ear obtained in Kharga men amounts to $6.3 \mathrm{~cm}$., a relatively large proportion. Two hundred and fifteen ears (right and left) of Alsatian and German males from 20 to over So years of age gave Schwalbe the average ear height of 6.59; but the 125 of these ears from individuals between 20 and 59 years of age, representing a more suitable group for comparison than the total Schwalbe series which includes the ears of many old individuals, give the average of $6.33 \mathrm{~cm}$.- much the same as at Kharga. The Alsatians and Germans are, however, of decidedly taller mean stature than the Kharga natives, and stature exercises a certain amount of direct influence on the size of the ears irrespective of other conditions.

As to further comparative data, Weisbach records the ear height of 6.4 in the Javanese, 6.3 in the Japanese, 6.2 in Hawaiians, 6.I in northern Chinese, Jews and Slavs, and $5.9 \mathrm{~cm}$. in Gypsies and Kaffirs; while the writer obtained the average of $5.99 \mathrm{~cm}$. in 20 apparently full-blood American negroes, and $6.76 \mathrm{~cm}$. in 76 American Indians-all males. The short Kharga natives have therefore evidently an ear somewhat above the general average in length and differing very perceptibly in this respect from that of the negro.

The range of variation of the dimension amounts to $2.0 \mathrm{~cm}$., or \pm 0.159 per unit of the average. The distribution of the measurement is regular.

${ }^{1}$ They are the same as those of Topinard (Eléments d'Anthropol. gén., Paris 1885 , p. 1004 et seq.), Weisbach (Zeit. f. Ethnologie. IX, Supplement, Berlin, I878), and Schwalbe (Beiträge zur Anthropologie des Ohres, Virchow's Festschrift, I89I, p. 95 et seq.) The breadth is measured at right angles to the height; the fixed branch of the sliding compass being applied, with some pressure, parallel to the long axis of the ear and so as to touch the anterior subcutaneous limit of the cartilaginous helix, while the movable branch is brought to touch the most posterior part of the skin of the pinna. 


\section{KHARGA OASIS, MEN: HEIGHT OF IEFT EAR}

Number of individuals measured: 105.

Average : $6.3 \mathrm{~cm}$. (Ist $50: 6.33 ; 2 \mathrm{~d} 50: 6.28 \mathrm{~cm}$.)

Median: $6.3 \mathrm{~cm}$. Modes: 6.2 and $6.4 \mathrm{~cm}$.

Minimum: $5.4 \mathrm{~cm}$. Maximum: $7.4 \mathrm{~cm}$.

Table of frequencies:

\begin{tabular}{|c|c|c|c|c|c|c|c|c|c|c|c|}
\hline ? & $\begin{array}{l}\dot{E} \\
\dot{U} \\
\dot{H}\end{array}$ & $\begin{array}{l}\dot{E} \\
0 \\
0 \\
\dot{n} \\
\dot{1} \\
\text { in }\end{array}$ & $\begin{array}{l}\dot{E} \\
0 \\
\infty \\
\dot{1} \\
\stackrel{1}{0} \\
\dot{1}\end{array}$ & $\begin{array}{l}\text { Ė } \\
\text { d } \\
0 \\
0 \\
\text { in }\end{array}$ & $\begin{array}{l}\dot{\Xi} \\
0 \\
\text { N. } \\
0 \\
1 \\
\stackrel{1}{0}\end{array}$ & $\begin{array}{l}\dot{E} \\
0 \\
+ \\
\dot{0} \\
m \\
0\end{array}$ & $\begin{array}{l}\varepsilon \\
\tilde{U} \\
b \\
0 \\
0 \\
1 \\
0 ٌ\end{array}$ & 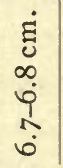 & 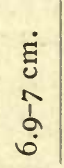 & 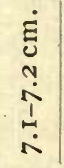 & 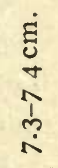 \\
\hline $\begin{array}{l}\text { Number of cases.......... } \\
\text { Per cent............... }\end{array}$ & $\begin{array}{c}2 \\
1.9\end{array}$ & $\begin{array}{c}2 \\
1.9\end{array}$ & $\begin{array}{c}8 \\
7.6\end{array}$ & $\begin{array}{c}15 \\
14.3\end{array}$ & 23 & $\begin{array}{c}21 \\
20.0\end{array}$ & $\begin{array}{c}18 \\
17.1\end{array}$ & $\begin{array}{c}6 \\
5.7\end{array}$ & $\begin{array}{c}3 \\
2.9\end{array}$ & $\begin{array}{c}4 \\
3.8\end{array}$ & $\begin{array}{c}3 \\
2.9\end{array}$ \\
\hline
\end{tabular}

The breadth of the ear in the Kharga natives averages $3.7 \mathrm{~cm}$. In the above referred to Schwalbe's series of Alsatians and Germans the same measurement averaged $3.97 \mathrm{~cm}$., or, if we take only the group of 125 ears of individuals from 20 to 59 years of age, which is more comparable with the Kharga series, the mean breadth was $3.91 \mathrm{~cm}$. The Kharga men have, evidently, an ear about equally as long, or only a trace shorter than the Alsatian and German whites, but one which is distinctly more narrow. The group of 20 American negroes measured by the writer, and who, notwithstanding their taller stature have been shown to possess a very noticeably shorter ear than the Kharga natives, gave a nearly equal breadth $(3.69 \mathrm{~cm}$.), as the latter, showing that their ear is relatively broader; while in the 76 Indians the measurements averaged $3.87 \mathrm{~cm}$.

The range of variation in the breadth of the ear in the Kharga men extends II mm., which amounts to \pm 0.149 per unit of the average. The distribution of the measurement is less uniform than that of the height of the ear.

\section{KHARGA OASIS, MEN: BREADTH OF LEFT EAR}

Number of individuals measured: 105.

Average: $3.7 \mathrm{~cm}$. (Ist $50: 3.77 ; 2 \mathrm{~d} 50: 3.66 \mathrm{~cm}$.)

Median: $3.7 \mathrm{~cm}$. Mode: $3.7 \mathrm{~cm}$.

Minımum: $3.3 \mathrm{~cm}$. Maximum: $4.4 \mathrm{~cm}$.

Table of frequencies:

\begin{tabular}{|c|c|c|c|c|c|c|c|c|c|c|c|c|}
\hline & $\begin{array}{l}\dot{E} \\
\ddot{y} \\
\ddot{m} \\
\dot{m} \\
\ddot{n} \\
\dot{m}\end{array}$ & 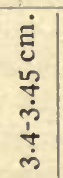 & 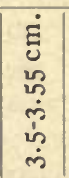 & $\begin{array}{l}\dot{E} \\
\dot{0} \\
\ddot{b} \\
\dot{m} \\
\dot{b} \\
\dot{m}\end{array}$ & 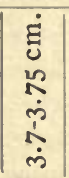 & $\begin{array}{l}\dot{E} \\
\dot{U} \\
\text { மூ } \\
\dot{m} \\
\dot{n} \\
\infty \\
\dot{m}\end{array}$ & $\begin{array}{l}\dot{\varepsilon} \\
\text { un } \\
\dot{m} \\
\dot{\alpha} \\
\dot{m}\end{array}$ & 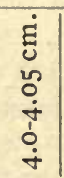 & 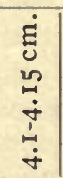 & 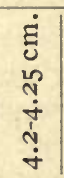 & $\begin{array}{l}\dot{\Xi} \\
\text { Un } \\
\text { ஸे } \\
\dot{+} \\
\dot{\dot{d}} \\
\dot{+}\end{array}$ & $\begin{array}{l}\dot{\Xi} \\
\dot{0} \\
\stackrel{+}{+}\end{array}$ \\
\hline $\begin{array}{l}\text { Number of cases...... } \\
\text { Per cent } . . . . . . . .\end{array}$ & $\begin{array}{c}6 \\
5 \cdot 7\end{array}$ & $\begin{array}{c}5 \\
4.8\end{array}$ & $\begin{array}{c}17 \\
16.2\end{array}$ & $\begin{array}{c}13 \\
12.4\end{array}$ & $\begin{array}{c}26 \\
24 \cdot 8\end{array}$ & $\begin{array}{c}15 \\
14.3\end{array}$ & $\begin{array}{c}\text { II } \\
10.5\end{array}$ & $\begin{array}{c}6 \\
5 \cdot 7\end{array}$ & $\begin{array}{c}3 \\
2.9\end{array}$ & $\begin{array}{c}\mathrm{I} \\
1.0\end{array}$ & $\begin{array}{c}\mathrm{I} \\
1.0\end{array}$ & $\stackrel{1}{1.0}$ \\
\hline
\end{tabular}


The mean of the two measurements of the ear $\left(\frac{\mathrm{H}+\mathrm{B}}{2}\right)$ gives the "dimension" (étendue, Topinard) or module (Schwalbe) of the ear, a determination useful for comparison. In the Kharga series, the average ear module is 5.0 , the least 4.4 , and the greatest 5.75 $\mathrm{cm}$. In the 20-59 year group of Schwalbe's series the module averages 5.12 ; in 13 male negroes measured by Topinard (1. c.) it was 4.78 , in 8 "Europeans" 4.86 , in 8 Melanesians 5.58 and in 3 Polynesians 5.2. In the 20 American negroes measured by the writer it was 4.84 , in the 76 Indians 5.3 . The mean size of the ear in the Kharga natives stands evidently nearer that of the whites than that of the negro, particularly when the stature differences are taken into consideration.

The percental relation of the breadth to the height of the ear $\left(\frac{B \times I O 0}{H}\right)$ gives the ear index, which is of some racial importance. In the Kharga men it averages 58.9. Topinard (1. c.) obtained for 8 "Europeans" 54.0; I3 African negroes 61.2; 8 Melanesians 59.5 and 3 Polynesians 60.0; while in Schwalbe's series the index ranges from 61.5 in the adults between 20 and 59 to 58.7 in those between 70 and 79 years of age. The 20 American negroes measured by the writer gave the mean index of 61.6, the 76 Indians 57.2. The ear of the Kharga men may therefore be regarded as a relatively narrow one, in which respect it differs from that of the Alsatians and the Germans, so far as represented in the Schwalbe series and especially from that of the negro.

The range of variation in the ear index in the Kharga men is rather large, extending over 17.4 units, or \pm 0.148 per unit of the average. Its distribution is regular.

KHARGA OASIS, MEN: EAR INDEX

Number of individuals measured: 105 .

Average : 58.9 . (Ist $50: 59.5 ; 2 \mathrm{~d} 50: 58.3$.)

Median: 59.0. Mode: group 58.5-60.0.

Minimum: 49.3. Maximum: 66.7.

Table of frequencies:

\begin{tabular}{|c|c|c|c|c|c|c|c|c|c|c|}
\hline . & 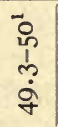 & $\begin{array}{l}\text { พै } \\
\text { เี }\end{array}$ & $\begin{array}{l}\text { फे } \\
1 \\
\text { nn }\end{array}$ & $\begin{array}{l}\text { in } \\
\text { ำ }\end{array}$ & $\begin{array}{l}\infty \\
\text { in } \\
1 \\
\text { in }\end{array}$ & $\begin{array}{l}8 \\
1 \\
0 \\
\text { n. }\end{array}$ & $\frac{\tilde{D}}{1}$ & $\begin{array}{l}\overrightarrow{0} \\
\tilde{0}\end{array}$ & $\begin{array}{l}8 \\
1 \\
10 \\
6\end{array}$ & $\begin{array}{l}\infty \\
1 \\
1 \\
\hat{b}\end{array}$ \\
\hline $\begin{array}{l}\text { Number of cases.............. } \\
\text { Per cent................... }\end{array}$ & $\begin{array}{c}2 \\
1.9\end{array}$ & $\begin{array}{c}2 \\
1.9\end{array}$ & $\begin{array}{c}7 \\
6.7\end{array}$ & $\begin{array}{c}15 \\
14.3\end{array}$ & 20 & $\begin{array}{c}22 \\
20.9\end{array}$ & $\begin{array}{c}19 \\
18.1\end{array}$ & $\begin{array}{c}\text { II } \\
10.5\end{array}$ & $\begin{array}{c}5 \\
4.8\end{array}$ & $\begin{array}{l}\text { I } \\
1.0\end{array}$ \\
\hline
\end{tabular}

${ }^{1}$ First group comprises indices to 50.5 , second from 50.6 to 52.5 , etc. 
The dimensions of the ear differ in the whites, it was shown by Schwalbe, with age, both the height and the breadth, but especially the former, increasing up to at least the 7oth year of age. The module and ear index modify accordingly, the module increasing, the index decreasing; in the words of the just mentioned author, " the ear in the aged is on the average absolutely longer and broader, but relatively narrower, than that in the young adult. The same conditions were found by the writer in the Indians, and they also exist among the Kharga Egyptians. As seen from the following table, the average height of the ear in the seventeen oldest men of the series is to that of the seventeen youngest adults as 109.9 to 100 ; the breadth is as 104.2 to 100; the module or mean diameter as 107.7 to I0O; while the cephalic index is but as 94.6 to roo. We are dealing here evidently with morphological conditions of wide extension, in which racial or tribal differences are restricted to degree and other secondary features of the phenomena.

KHARGA OASIS, MEN: DIMENSIONS OF EARS ACCORDING TO AGE

\begin{tabular}{|c|c|c|c|c|c|c|c|}
\hline \multicolumn{4}{|c|}{17 youngest men: 21.26 years } & \multicolumn{4}{|c|}{ 17 oldest men: $55-65$ years } \\
\hline $\begin{array}{l}\text { Age of } \\
\text { subject }\end{array}$ & $\begin{array}{l}\text { Height of } \\
\text { left ear }\end{array}$ & $\begin{array}{l}\text { Breadth of } \\
\text { left ear }\end{array}$ & Ear index & $\begin{array}{l}\text { Age of } \\
\text { subject }\end{array}$ & $\begin{array}{l}\text { Height of } \\
\text { left ear }\end{array}$ & $\begin{array}{c}\text { Breadth of } \\
\text { left ear }\end{array}$ & Ear index \\
\hline years & $\mathrm{cm}$. & $\mathrm{cm}$. & & years & $\mathrm{cm}$. & $\mathrm{cm}$. & \\
\hline $2 \mathrm{I}$ & 6.0 & $3 \cdot 55$ & 59.2 & 55 & $7 \cdot 1$ & $4 \cdot 3$ & 60.6 \\
\hline 22 & 6.1 & 3.85 & 63.1 & 55 & 6.2 & $3 \cdot 3$ & 53.2 \\
\hline 23 & 5.8 & 3.8 & 65.5 & 55 & 6.65 & $3 \cdot 9$ & 58.6 \\
\hline 23 & $5 \cdot 4$ & $3 \cdot 45$ & 63.9 & 55 & 6.3 & $3 \cdot 9$ & $6 I .9$ \\
\hline 24 & 6.1 & $3 \cdot 3$ & $54 . I$ & 55 & 6.1 & $3 \cdot 9$ & 63.9 \\
\hline 24 & 6.0 & 3.6 & 60.0 & 55 & 6.7 & $3 \cdot 75$ & 56.0 \\
\hline 24 & 6.4 & 3.8 & $59 \cdot 4$ & 55 & 5.8 & 3.6 & 62.1 \\
\hline 24 & $5 \cdot 7$ & $3 \cdot 3$ & 57.9 & 55 & 7.0 & 3.8 & $54 \cdot 3$ \\
\hline 24 & 6.4 & $3 \cdot 75$ & 58.6 & 55 & 6.3 & $3 \cdot 5$ & 55.6 \\
\hline 25 & $5 \cdot 4$ & $3 \cdot 5$ & 64.8 & 55 & 6.2 & $3 \cdot 5$ & 56.4 \\
\hline 25 & $5 \cdot 9$ & $3 \cdot 3$ & 55.9 & 55 & $7 \cdot 3$ & $4 \cdot 2$ & 57.5 \\
\hline 25 & 6.0 & $3 \cdot 75$ & 62.5 & 58 & 7.1 & $3 \cdot 5$ & $49 \cdot 3$ \\
\hline 26 & 6.45 & 3.65 & 56.6 & 60 & 6.9 & $4 \cdot 0$ & 58.0 \\
\hline 26 & 6.3 & $3 \cdot 7$ & 58.7 & 60 & $7 \cdot 3$ & $3 \cdot 7$ & 50.7 \\
\hline 26 & 6.2 & 3.65 & 58.9 & 60 & 6.4 & $3 \cdot 5$ & 54.7 \\
\hline 26 & 6.4 & $3 \cdot 7$ & 57.8 & 60 & 6.5 & $3 \cdot 5$ & 53.8 \\
\hline 26 & 6.5 & $3 \cdot 5$ & 53.8 & 65 & $7 \cdot 4$ & 3.8 & $5 I .3$ \\
\hline
\end{tabular}

Averages :

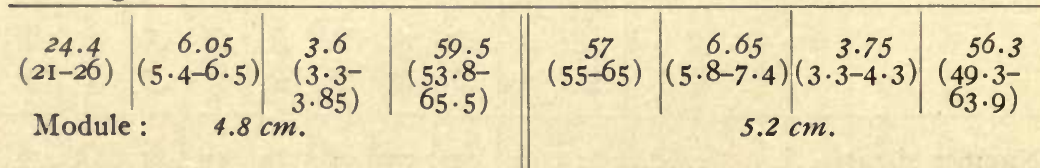

General averages of the whole series (105): Height 6.3; breadth 3.7; module $5.0 \mathrm{~cm}$.; index 58.9 .

${ }^{1}$ L. c., pp. 123-124 et seq. 


\section{ADDITIONAL MEASUREMENTS}

It was, regrettably, impracticable to secure at Kharga any measurements of the covered parts of the body. It was observed that the chest, abdomen and pelvic regions are in general moderately developed, and so far as could be perceived they present no uncommon features. It was possible, however, to measure the hands, feet and the calf of the leg, with the following results.

\section{The Hand}

On the hand the writer takes two measurements, the length and breadth. The length is taken in full extension of the hand from the middle of a straight line connecting the proximal boundaries of the thenar and hypothenar eminences, to the tip of the longest finger. The line frequently, but not always, coincides with a delimiting folding or wrist line in the skin. The breadth measured is the maximum breadth of the palm, taken, in full extension of the hand, from the angle between the thumb and the palm across the latter at right angles to the length. These measurements secure, the writer believes, the expression of the racial features of the hand better than others. And in view of the fact that the right hand is often more modified by the work or habits of the individual than the left, measurements are restricted to the latter.

At Kharga the left hand was measured in 100 men, and the following two tables show the results.

\section{KHARGA OASIS, MEN: LENGTH OF LEFT HAND}

Number of individuals measured: 100.

Average: $19.0 \mathrm{~cm}$. (Ist $50: 19.1 ; 2 \mathrm{~d} 50: 18.9 \mathrm{~cm}$.)

Median : $I 8.9 \mathrm{~cm}$. Modes : $I 8.6$ and $I 9.7 \mathrm{~cm}$.

Minimum: $17.2 \mathrm{~cm}$. Maximum: $21.7 \mathrm{~cm}$.

Table of frequencies:

\begin{tabular}{|c|c|c|c|c|c|c|c|c|c|c|}
\hline . & 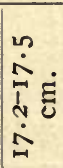 & 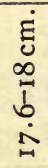 & \begin{tabular}{l}
$n$ \\
$\infty$ \\
$\infty$ \\
1 \\
1 \\
\hdashline \\
$\infty$ \\
$\infty$ \\
0 \\
1
\end{tabular} & 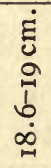 & 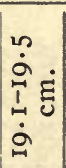 & 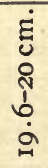 & 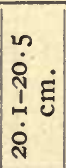 & 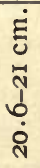 & 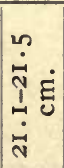 & $\begin{array}{l}\dot{E} \\
\hat{U} \\
\dot{\vec{N}}\end{array}$ \\
\hline Number and pér cent of cases.. & 1 & 11 & 18 & 26 & 15 & 19 & 6 & 2 & 1 & 1 \\
\hline
\end{tabular}




\section{KHARGA OASIS, MEN: BREADTH OF LEFT HAND}

Number of individuals measured: 100 .

Average $8.8 \mathrm{~cm}$. (Ist $50: 8.9 ; 2 \mathrm{~d} 50: 8.7 \mathrm{~cm}$.)

Median : $\delta .9 \mathrm{~cm}$. Mode : $9.1 \mathrm{~cm}$

Minimum: $7.7 \mathrm{~cm}$. Maximum: $9.8 \mathrm{~cm}$.

Table of frequencies:

\begin{tabular}{|c|c|c|c|c|c|c|c|c|c|c|c|}
\hline & 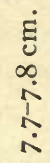 & $\begin{array}{l}\dot{E} \\
\text { U. } \\
\infty \\
\vdots \\
\stackrel{\leftrightarrow}{n}\end{array}$ & $\begin{array}{c}\dot{\Xi} \\
\text { d } \\
v \\
\infty \\
\infty \\
\infty \\
\infty\end{array}$ & $\begin{array}{c}\tilde{\Xi} \\
\dot{J} \\
+ \\
\infty \\
\infty \\
\infty \\
\infty\end{array}$ & 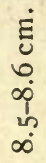 & $\begin{array}{l}\dot{E} \\
0 \\
\infty \\
\infty \\
1 \\
\hat{\infty} \\
\infty\end{array}$ & $\begin{array}{l}\dot{E} \\
\hat{U} \\
\hat{i} \\
\hat{\infty} \\
\infty\end{array}$ & 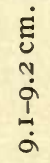 & 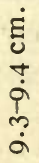 & 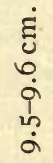 & 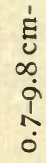 \\
\hline $\begin{array}{l}\text { Number and per cent of } \\
\text { cases......................... }\end{array}$ & 2 & 1 & 8 & 8 & 13 & 17 & 19 & 17 & 9 & 4 & 2 \\
\hline
\end{tabular}

It is seen that the average length and especially the average breadth of the hand are moderate. The range of the variation is proportionate, extending for the length over $4.5 \mathrm{~cm}$., or \pm 0 II 8 per unit of the mean, and for the breadth over $1.9 \mathrm{~cm}$., or \pm 0.108 per unit of the mean. The hand module $\left(\frac{L+B}{2}\right)$ averages I3.9, the hand index $\left(\frac{\mathrm{B} \times 100}{\mathrm{~L}}\right) 46.3$.

\section{The Foot}

Conformably with the practice of measuring the left ear and especially the left hand, the writer measures also the left foot. The dimensions ascertained are the maximum length and maximum breadth (back of the toes), while the foot reposes so lightly on the floor that there is no deformation. The results of such measurements on I03 of the Kharga men are as follows:

\section{KHARGA OASIS, MEN: LENGTH OF LEFT FOOT}

Number of individuals measured: 103.

Average: $25.4 \mathrm{~cm}$. (Ist $50: 25.6 \mathrm{~cm}$; $2 \mathrm{~d} 50: 25.2 \mathrm{~cm}$.)

Median: $25.5 \mathrm{~cm}$. Modes: 24.6 and $26.2 \mathrm{~cm}$.

Minimum: $20.3 \mathrm{~cm}$. Maximum: $28.4 \mathrm{~cm}$.

Table of frequencies:

\begin{tabular}{|c|c|c|c|c|c|c|c|c|c|c|c|c|c|}
\hline & $\begin{array}{l}\dot{\Xi} \\
\dot{m} \\
\dot{d}\end{array}$ & $\begin{array}{l}\dot{\Xi} \\
\tilde{\text { Jे }} \\
\tilde{\text { N }}\end{array}$ & 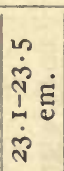 & $\begin{array}{l}\dot{\varepsilon} \\
\dot{\tilde{N}} \\
\tilde{d} \\
\underline{\tilde{d}} \\
\dot{\tilde{d}}\end{array}$ & 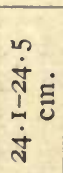 & 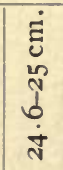 & 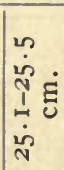 & 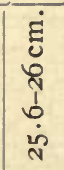 & $\begin{array}{l}10 \\
\dot{0} \\
1 \\
1 \\
\dot{0} \\
\dot{\theta}\end{array}$ & 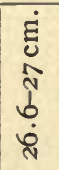 & 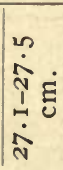 & 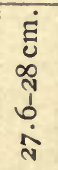 & 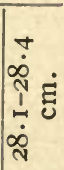 \\
\hline $\begin{array}{l}\text { Number of cases. } \\
\text { Per cent ......... }\end{array}$ & $\begin{array}{c}\mathrm{I} \\
1.0\end{array}$ & $\begin{array}{c}2 \\
1.9\end{array}$ & $\begin{array}{c}3 \\
2.9\end{array}$ & 8.7 & $\begin{array}{c}7 \\
6.8\end{array}$ & $\begin{array}{c}18 \\
17.5\end{array}$ & $\begin{array}{c}15 \\
14.6\end{array}$ & $\begin{array}{c}13 \\
12.6\end{array}$ & $\begin{array}{c}16 \\
15.5\end{array}$ & $\begin{array}{r}9 . \\
8.7\end{array}$ & $\begin{array}{l}5 \\
4.9\end{array}$ & $\begin{array}{c}3 \\
2.9\end{array}$ & $\begin{array}{c}2 \\
1.9\end{array}$ \\
\hline
\end{tabular}




\section{KHARGA OASIS, MEN: BREADTH OF LEFT FOOT}

Number of individuals measured: I03. Average : $10.0 \mathrm{~cm}$. (Ist 50: $10.1 ; 2 \mathrm{~d} 50: 9.9 \mathrm{~cm}$.)

Median : $10.0 \mathrm{~cm}$. Mode: $I 0 . I \mathrm{~cm}$.

Minimum: $8.8 \mathrm{~cm}$. Maximum : $11.2 \mathrm{~cm}$.

Table of frequencies:

\begin{tabular}{|c|c|c|c|c|c|c|c|c|c|c|c|c|c|}
\hline & $\begin{array}{l}\dot{घ} \\
\infty \\
\infty \\
\infty\end{array}$ & $\begin{array}{c}\text { E્ } \\
0 \\
0 \\
0 \\
0 \\
\infty\end{array}$ & 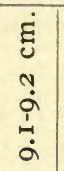 & 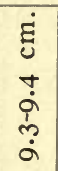 & $\begin{array}{l}\dot{E} \\
\dot{u} \\
0 \\
\dot{0} \\
\dot{1} \\
\dot{0}\end{array}$ & $\begin{array}{l}\dot{E} \\
\dot{U} \\
\infty \\
\dot{0} \\
\stackrel{1}{1} \\
\dot{0}\end{array}$ & $\begin{array}{l}\dot{d} \\
0 \\
0 \\
\dot{0} \\
\text { ó }\end{array}$ & 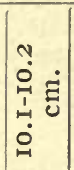 & $\begin{array}{l}+ \\
0 \\
0 \\
0 \\
\tilde{n} \\
\dot{\varepsilon} \\
0 \\
0\end{array}$ & $\begin{array}{l}0 \\
0 \\
0 \\
\dot{1} \\
\dot{n} \\
\dot{0} \\
\dot{0}\end{array}$ & $\begin{array}{l}\infty \\
0 \\
0 \\
1 \\
\\
\\
\dot{0} \\
0 \\
0\end{array}$ & 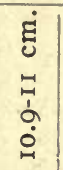 & ¿ّ \\
\hline $\begin{array}{l}\text { Number of cases. } \\
\text { Per cent ........ }\end{array}$ & $\begin{array}{c}3 \\
2.9\end{array}$ & $\begin{array}{c}2 \\
1.9\end{array}$ & $\begin{array}{c}4 \\
3.9\end{array}$ & $\begin{array}{c}4 \\
3.9\end{array}$ & $\begin{array}{c}13 \\
12.6\end{array}$ & $\begin{array}{c}14 \\
13.6\end{array}$ & $\begin{array}{c}14 \\
13.6\end{array}$ & $\begin{array}{c}14 \\
13.6\end{array}$ & $\begin{array}{c}14 \\
13.6\end{array}$ & $\begin{array}{c}8 \\
7.8\end{array}$ & $\begin{array}{c}8 \\
7.8\end{array}$ & $\begin{array}{c}3 \\
2.9\end{array}$ & $\begin{array}{c}2 \\
1.9\end{array}$ \\
\hline
\end{tabular}

The preceding data show that the foot of the Kharga men, like the hand, is of moderate proportions. The individual variation is but slightly larger than in the hand; it extends for the length over $8.1 \mathrm{~cm}$., or \pm 0.159 per unit of the average, and for the breadth over $2.4 \mathrm{~cm}$. or \pm 0.120 per unit of the average. The mean module of the foot $\left(\frac{\mathrm{L}+\mathrm{B}}{2}\right)$ I7.I, the mean index $\left(\frac{\mathrm{B} \times 100}{\mathrm{~L}}\right) 39.4$. These dimensions will be mainly useful for future comparisons.

An inquiry as to the bearing of stature on the absolute and relative dimensions of the hands and feet, brings out interesting results. As will be seen from the following figures, there is a clear, direct correlation between the height of the body and length (as well as breadth) of the hands as well as the feet; but the index in each case shows but little alteration. The correlation between the stature and the hand and foot length is so close that proportions of the latter to the stature are almost identical in the shortest and the tallest groups of the series, and the little change in the index shows that the same must be true of the breadth of the two parts.

Another inquiry was directed into the effects on the hand and foot dimensions of age, and the results of this are wholly negative. The differences in the mean hand and foot length (as well as breadth) and their indices between the group of the youngest and that of the oldest men (both groups showing nearly equal average of stature). are so small as to be quite negligible. 
KHARGA OASIS, MEN: RELATION OF THE LENGTH OF THE HANDS AND FEET, AND OF THEIR INDICES, TO STATURE AND AGE

Length and Indices of Hands and Feet in Shortest and Tallest Individuals 17 SHORTEST MEN: 158.5 CM. AND BELOW

\begin{tabular}{|c|c|c|c|c|}
\hline Stature & $\begin{array}{l}\text { Length of left } \\
\text { hand }\end{array}$ & Hand index & $\begin{array}{l}\text { Length of left } \\
\text { foot }\end{array}$ & Foot index \\
\hline $\begin{array}{l}\mathrm{cm} . \\
152.3 \\
153.6 \\
154.5 \\
155.2 \\
155.7 \\
155.7 \\
155.9 \\
156.0 \\
156.5 \\
157.5 \\
157.6 \\
157.8 \\
158.3 \\
158.3 \\
158.4 \\
158.5 \\
158.5\end{array}$ & $\begin{array}{l}c m . \\
18.8 \\
18.3 \\
17.6 \\
18.3 \\
18.0 \\
18.3 \\
18.6 \\
18.3 \\
18.6 \\
18.1 \\
18.9 \\
17.9 \\
18.4 \\
18.2 \\
18.8 \\
18.3 \\
18.6\end{array}$ & $\begin{array}{l}47.3 \\
47.0 \\
44.3 \\
47.2 \\
50.6 \\
44.8 \\
45.2 \\
45.9 \\
43.0 \\
47.0 \\
46.0 \\
43.0 \\
47.3 \\
46.7 \\
46.8 \\
45.4 \\
44.1\end{array}$ & $\begin{array}{l}\mathrm{cm} . \\
23.7 \\
20.3 \\
23.3 \\
24.1 \\
24.6 \\
24.2 \\
24.9 \\
23.5 \\
24.7 \\
23.9 \\
25.1 \\
23.2 \\
23.9 \\
24.2 \\
24.7 \\
24.1 \\
25.4\end{array}$ & $\begin{array}{l}40.5 \\
46.8 \\
37.8 \\
42.7 \\
44.2 \\
40.1 \\
39.8 \\
38.3 \\
36.4 \\
36.8 \\
39.8 \\
40.1 \\
41.0 \\
40.5 \\
42.1 \\
37.7 \\
39.8\end{array}$ \\
\hline \multicolumn{5}{|l|}{ Averages; } \\
\hline $\begin{array}{c}156.5 \\
(152.3-158.5) \\
\text { Proportion to } \\
\text { stature }(5=1000)\end{array}$ & 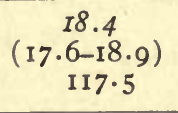 & $\begin{array}{c}46.0 \\
(40 \cdot 3-50.6) \\
\ldots\end{array}$ & $\begin{array}{c}24.0 \\
(20 \cdot 3-25 \cdot 4) \\
153 \cdot 4\end{array}$ & $\begin{array}{c}40.3 \\
(36.4-46.8) \\
\ldots .\end{array}$ \\
\hline
\end{tabular}

17 TAlLest MEN: ABOVE $168.5 \mathrm{CM}$.

\begin{tabular}{|c|c|c|c|c|}
\hline Stature & $\begin{array}{l}\text { Length of left } \\
\text { hand }\end{array}$ & Hand index & $\begin{array}{l}\text { Length of left } \\
\text { foot }\end{array}$ & Foot index \\
\hline $\mathrm{cm}$ & $\mathrm{cm}$. & & $\mathrm{cm}$. & \\
\hline $\begin{array}{l}168.6 \\
168.6\end{array}$ & $\begin{array}{l}19.9 \\
20.0\end{array}$ & 49.2 & $\begin{array}{l}28.4 \\
26.3\end{array}$ & 38.4 \\
\hline 168.8 & $\begin{array}{l}20.0 \\
19.4\end{array}$ & $\begin{array}{l}43.5 \\
45.9\end{array}$ & 25.2 & $\begin{array}{l}39.4 \\
38.5\end{array}$ \\
\hline 168.8 & $\begin{array}{l}19.4 \\
21.7\end{array}$ & $\begin{array}{l}43.9 \\
40.5\end{array}$ & 27.7 & 37.6 \\
\hline 168.9 & 19.9 & 46.7 & 26.2 & 38.5 \\
\hline 169.4 & 18.6 & 44.6 & 25.0 & 38.0 \\
\hline 169.4 & I8.6 & 47.8 & 24.8 & 38.3 \\
\hline 169.4 & 20.4 & 45.6 & 26.2 & 38.2 \\
\hline 170.5 & 19.7 & 45.7 & 27.2 & 38.4 \\
\hline 171.3 & 19.6 & 46.4 & 26.9 & 39.7 \\
\hline 172.2 & I8.5 & $48 . I$ & 25.5 & 41.9 \\
\hline 172.4 & 19.7 & 48.7 & 25.7 & 42.0 \\
\hline 172.4 & 20.1 & $47 \cdot 3$ & 26.9 & 38.7 \\
\hline 172.5 & I9.4 & 46.9 & 26.2 & 38.5 \\
\hline 172.7 & 19.9 & 46.2 & 25.9 & $40 . I$ \\
\hline I 73.8 & $2 \mathrm{I} .5$ & 44.6 & 27.2 & 39.3 \\
\hline 174.5 & I9.4 & 48.4 & 27.1 & 38.7 \\
\hline \multicolumn{5}{|l|}{ Averages: } \\
\hline $\begin{array}{c}I 70.8 \\
(168.6-174.5)\end{array}$ & $\begin{array}{c}19.8 \\
(18 \cdot 5-21.7)\end{array}$ & $\begin{array}{c}46.4 \\
(40 \cdot 5-49 \cdot 2)\end{array}$ & $\begin{array}{c}26.4 \\
(24 \cdot 8-28 \cdot 4)\end{array}$ & $\begin{array}{c}39 . I \\
(37.6-42.0)\end{array}$ \\
\hline .... & II 5.9 & & I 54.6 & \\
\hline
\end{tabular}


KHARGA OASIS, MEN: RELATION OF THE LENGTH OF THE HANDS AND FEET, AND OF THEIR INDICES, TO STATURE AND AGE-Continued

Length and Indices of Hands and Feet in Youngest and Oldest Individuals 17 YOUNGEST MEN: 21 TO 26 YEARS OF AGE

\begin{tabular}{|c|c|c|c|c|}
\hline $\begin{array}{c}\text { Approximate } \\
\text { age }\end{array}$ & $\begin{array}{l}\text { Length of left } \\
\text { hand }\end{array}$ & Hand index & $\begin{array}{l}\text { Length of left } \\
\text { foot }\end{array}$ & Foot index \\
\hline Years & $\mathrm{cm}$. & & $\mathrm{cm}$. & \\
\hline $\begin{array}{l}2 \mathrm{I} \\
22\end{array}$ & $\begin{array}{l}\text { I8.4 } \\
\text { I9.I }\end{array}$ & $\begin{array}{l}46.2 \\
47.6\end{array}$ & 23.7 & $\begin{array}{l}42.1 \\
38.8\end{array}$ \\
\hline $\begin{array}{l}22 \\
23\end{array}$ & $\begin{array}{l}\text { I9.I } \\
\text { I9.3 }\end{array}$ & $\begin{array}{l}47.0 \\
43.5\end{array}$ & 24.7 & $\begin{array}{l}38.8 \\
38.5\end{array}$ \\
\hline $\begin{array}{l}23 \\
23\end{array}$ & $\begin{array}{l}17.5 \\
17.9\end{array}$ & 43.0 & $\begin{array}{l}25.7 \\
23.2\end{array}$ & $\begin{array}{l}30.5 \\
40.1\end{array}$ \\
\hline 24 & 18.9 & 47.6 & 25.2 & $42 . I$ \\
\hline 24 & I8.7 & 44.2 & 25.7 & $37 \cdot 3$ \\
\hline 24 & 21.7 & 40.5 & 27.7 & 37.6 \\
\hline 24 & I9.0 & 47.9 & 26.2 & 38.2 \\
\hline 24 & I7.9 & 47.5 & 22.7 & 43.2 \\
\hline 25 & I8.I & 47.0 & 23.9 & 36.8 \\
\hline 25 & I7.6 & 46.6 & 22.7 & 40.5 \\
\hline 25 & I9.4 & 43.8 & 25.8 & $39 . I$ \\
\hline 26 & 18.9 & 50.3 & 26.2 & 39.3 \\
\hline 26 & 20.3 & 46.3 & 27.2 & 38.2 \\
\hline 26 & I8.6 & 47.8 & 24.8 & 38.3 \\
\hline 26 & I9.6 & 44.4 & 25.0 & 37.2 \\
\hline 26 & 19.7 & 46.2 & 27.6 & $39 . I$ \\
\hline
\end{tabular}

Averages:

\begin{tabular}{c|c|c|c|c}
\hline $24 \cdot 4$ & $\begin{array}{c}19.0 \\
(2 \mathrm{I}-26)\end{array}$ & $\begin{array}{c}45 \cdot 9 \\
(17 \cdot 6-21 \cdot 7)\end{array}$ & $\begin{array}{c}25.2 \\
(40 \cdot 5-50 \cdot 3)\end{array}$ & $\begin{array}{c}39.2 \\
(22 \cdot 7-27 \cdot 7)\end{array}$ \\
\hline
\end{tabular}

17 OLDEST MEN: 55 TO 65 YBARS OF AGE

\begin{tabular}{c|c|c|c|c}
\hline $\begin{array}{c}\text { Approximate } \\
\text { age }\end{array}$ & $\begin{array}{c}\text { Length of left } \\
\text { hand }\end{array}$ & Hand index & $\begin{array}{c}\text { Length of left } \\
\text { foot }\end{array}$ & Foot index \\
\hline Years & cm. & & $c m$. & \\
55 & 18.6 & $44 . I$ & 23.9 & $4 I .0$ \\
55 & 18.5 & $48 . I$ & 25.5 & $4 I .9$ \\
55 & 18.7 & 49.7 & 26.3 & 41.4 \\
55 & 19.0 & 45.8 & 25.8 & 38.8 \\
55 & 18.0 & 47.8 & 24.9 & 40.6 \\
55 & 18.6 & 43.0 & 24.7 & 36.4 \\
55 & 18.9 & 46.0 & 25.1 & 39.8 \\
55 & 17.9 & 45.8 & 25.4 & 38.6 \\
55 & 18.3 & 44.8 & 24.2 & 40.1 \\
55 & 18.3 & 49.7 & 25.5 & 38.4 \\
55 & 20.7 & 44.9 & 26.7 & 41.2 \\
58 & 18.5 & 45.9 & 24.6 & 39.0 \\
60 & 19.1 & 49.2 & 25.6 & 40.2 \\
60 & 19.7 & 45.2 & 25.9 & 40.1 \\
60 & 19.0 & 45.8 & 25.7 & 39.3 \\
60 & 18.7 & 45.4 & 24.8 & 38.3 \\
65 & 17.2 & 47.1 & 23.6 & 39.4 \\
\hline
\end{tabular}

Averages:

\begin{tabular}{|c|c|c|c|c|}
\hline $\begin{array}{c}57 \\
(55-65)\end{array}$ & $\begin{array}{c}18.7 \\
(17 \cdot 2-20 \cdot 7)\end{array}$ & $\begin{array}{c}46 \cdot 4 \\
(43 \cdot 0-49 \cdot 7)\end{array}$ & $\begin{array}{c}25.2 \\
(23 \cdot 6-26 \cdot 7)\end{array}$ & $\begin{array}{c}39 \cdot 7 \\
(36 \cdot 4-41 \cdot 9)\end{array}$ \\
\hline
\end{tabular}

The average stature of the $I 7$ youngest men is $162.5 \mathrm{~cm}$, , that of the 17 oldest $16 r .8 \mathrm{~cm}$. - no influential difference. 


\section{Girth of the Leg}

The maximum girth of the leg is a measurement which in the main indicates the individual development of the musculature of the part, but collectively is also of some anthropological significance, for regardless of age, health, nourishment and exercise of the part, all of which agencies affect its dimension, there are certain peoples, such as the Indians for instance, who have in general a smaller calf than the whites.

The average maximum circumference of the left leg, which is measured by the writer, amounts in white men less than 50 years of age, to about $36 \mathrm{~cm}$., in the Indian the writer obtained, on 200 individuals in good state of bodily preservation, $34.0 \mathrm{~cm}$., and in 20 apparently full-blood American negroes $36.9 \mathrm{~cm}$. One hundred and eleven Kharga men in good condition gave the mean of only 32.0 $\mathrm{cm}$., and in more than a half the measurement was smaller. The significance of this relatively poor record is doubtless in the main not racial, but connected with the poor nutrition of the majority of the Oasis people and their consequent subnormal development, which was shown already by other determinations.

KHARGA OASIS, MEN: MAXIMUM GIRTH OF LEG

Number of observations: III. ${ }^{1}$

Average: $32.0 \mathrm{~cm}$. (Ist $50: 32.1 ; 2 \mathrm{~d} 50: 31.9 \mathrm{~cm}$.)

Median : $31.5 \mathrm{~cm}$. Mode: $31.0-32.0 \mathrm{~cm}$.

Minimum: $27.3 \mathrm{~cm}$. Maximum: $37.0 \mathrm{~cm}$.

Table of frequencies:

\begin{tabular}{|c|c|c|c|c|c|c|c|c|c|c|}
\hline & $\begin{array}{c}\dot{E} \\
\dot{E} \\
\infty \\
\stackrel{N}{1} \\
\stackrel{\mathfrak{N}}{\sim}\end{array}$ & 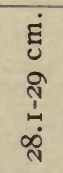 & 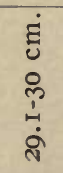 & $\begin{array}{l}\dot{E} \\
\text { U } \\
\ddot{1} \\
\ddot{1} \\
\dot{0}\end{array}$ & 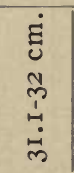 & 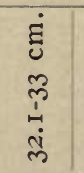 & $\begin{array}{l}\dot{\Xi} \\
0 \\
\dot{m} \\
\stackrel{\sim}{m} \\
\dot{m}\end{array}$ & 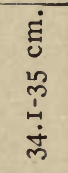 & $\begin{array}{l}\text { घ் } \\
0 \\
0 \\
\stackrel{1}{1} \\
\dot{m}\end{array}$ & $\begin{array}{l}\dot{\Xi} \\
\hat{0} \\
\hat{n} \\
\stackrel{0}{0}\end{array}$ \\
\hline $\begin{array}{l}\text { Number of cases.... } \\
\text { Per cent........... }\end{array}$ & $\stackrel{2}{1.8}$ & $\begin{array}{l}3 \\
2.7\end{array}$ & $\begin{array}{r}\text { II } \\
9.9\end{array}$ & $\begin{array}{c}22 \\
19.8\end{array}$ & $\begin{array}{c}23 \\
20.7\end{array}$ & $\begin{array}{c}20 \\
18.0\end{array}$ & $\begin{array}{c}17 \\
15.3\end{array}$ & 8.1 & $\begin{array}{l}3 \\
2.7\end{array}$ & $\begin{array}{c}\text { I } \\
0.9\end{array}$ \\
\hline
\end{tabular}

${ }^{1}$ No cases of plain emaciation, senile or otherwise, included.

\section{SUMMARY OF THE MAIN RESULTS SHOWN BY MEASUREMENTS; TABLES OF COMPARISON}

The Kharga men are, on the average, of short stature; the head is of moderate size, medium height and dolicho- to mesocephalic in form; the face is rather narrow, the nose mesorhynian, the mouth of fair size; the ears are rather long and narrow, the hands and feet of medium proportions, the legs small. In general the measurements indicate a rather poor physical development. 
The principal available data for comparison of the measurements are gathered in the following tables. The first of these shows the close relations of the Kharga natives with the Copt, Fellaheen and the non-negro Nubian; the second demonstrates the important differences between the Oasis men and the Nubian, Soudanese and the other negroes.

COMPARISON OF MEASUREMENTS OF THE KHARGA NATIVES AND VARIOUS OTHER GROUPS OF EGYPTIANS AND NUBIANS (MALES)

\begin{tabular}{|c|c|c|c|c|c|}
\hline \multirow[b]{2}{*}{ Males } & \multirow[b]{2}{*}{ Author } & \multirow[b]{2}{*}{ Stature } & \multicolumn{3}{|c|}{ Head } \\
\hline & & & Length & Breadth & $\begin{array}{c}\text { Cephalic } \\
\text { index }\end{array}$ \\
\hline I50 Kharga Oasis ...... & Hrdlička & $\begin{array}{c}\mathrm{cm} . \\
\mathrm{I} 63.8\end{array}$ & $\begin{array}{l}\mathrm{cm} . \\
\mathrm{I} 8.9\end{array}$ & $\begin{array}{l}\mathrm{cm} . \\
\mathrm{I} 4 \cdot \mathrm{I}\end{array}$ & 74.9 \\
\hline 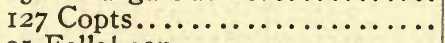 & Chantre & 166.0 & 18.85 & $\mathrm{I} 4 \cdot 2$ & 75.2 \\
\hline 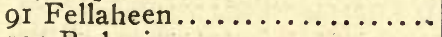 & Chantre & 168.4 & $19 \cdot 0$ & $14 \cdot 2$ & $74 \cdot 7$ \\
\hline 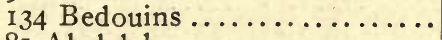 & Chantre & 167.8 & 19.27 & $14 \cdot 25$ & 73.9 \\
\hline 8I Ababdeh.................. & Chantre & 166.0 & 18.9 & $14 \cdot 1$ & 74.6 \\
\hline 64 Barabra................... & Chantre & I68.2 & I8.9 & $14 \cdot 4$ & 76.4 \\
\hline 78 Bicharieh ................. & Chantre & I65.0 & I8. I & $14 \cdot 3$ & 79.0 \\
\hline 369 Egyptian Moslems, selected & Myers & $(171.0)$ & $19 \cdot 46$ & I4. 43 & 74.26 \\
\hline 44 Copts, selected............. & Myers & $(\mathrm{I} 7 \mathrm{I} \cdot 0)$ & $19 \cdot 30$ & I4.3I & 74.0 \\
\hline
\end{tabular}

\begin{tabular}{|c|c|c|c|c|c|c|}
\hline \multirow[b]{2}{*}{ Males } & \multicolumn{2}{|c|}{ Face } & \multicolumn{3}{|c|}{ Nose } & \multirow[b]{2}{*}{$\begin{array}{c}\text { Mouth } \\
\text { breadth }\end{array}$} \\
\hline & $\begin{array}{l}\text { Chin- } \\
\text { nasion } \\
\text { height }\end{array}$ & $\mid \begin{array}{c}\text { Diameter } \\
\text { bizy- } \\
\text { gomatic } \\
\text { maximum }\end{array}$ & Height & Breadth & $\underset{\text { index }}{\text { Nasal }}$ & \\
\hline 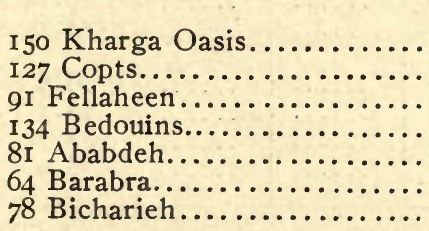 & $\begin{array}{c}\text { II } \cdot 35 \\
\ldots \ldots \\
\ldots \ldots \\
\ldots \ldots \\
\ldots \ldots \\
\ldots \ldots\end{array}$ & $\begin{array}{l}\mathrm{cm} . \\
\text { I3.15 } \\
\text { I } 3.25 \\
12.93 \\
\text { I3.2 } \\
\text { I3.1 } \\
\text { 13.0 } \\
\text { I } 2.7\end{array}$ & $\begin{array}{l}c m \\
4 \cdot 87 \\
(4 \cdot 7)^{1} \\
4 \cdot 6) \\
(4 \cdot 65) \\
(4 \cdot 5) \\
4 \cdot 69) \\
(4 \cdot 6)\end{array}$ & $\begin{array}{l}c m \\
3 \cdot 73 \\
3 \cdot 6 \\
3 \cdot 7 \\
3 \cdot 56 \\
3 \cdot 7 \\
3 \cdot 8 \\
3 \cdot 5\end{array}$ & $\begin{array}{l}76.6 \\
(77.6) \\
81.0 \\
(76.6) \\
(82.2 \\
(81.1) \\
76.1)\end{array}$ & $\begin{array}{l}5 \cdot 4 \\
5 \cdot 2 \\
5 \cdot 1 \\
5 \cdot 1 \\
5 \cdot 2 \\
5 \cdot 3 \\
5 \cdot 0\end{array}$ \\
\hline $\begin{array}{l}369 \text { Egvptian Moslems, selected } \\
44 \text { Copts, selected............ }\end{array}$ & $\begin{array}{l}\text { II } \cdot 45^{2} \\
\text { II } 47\end{array}$ & $\begin{array}{l}14 \cdot 36^{3} \\
13 \cdot 66^{5}\end{array}$ & $\begin{array}{l}4 \cdot 83 \\
4 \cdot 78\end{array}$ & $\begin{array}{l}3 \cdot 66 \\
3 \cdot 59\end{array}$ & $\begin{array}{l}75.83^{4} \\
75.77^{6}\end{array}$ & $\cdots$ \\
\hline
\end{tabular}

'All Chantre's measurements of the height of the nose are evidently too low; no such low averages of nasal height have been reported on non-negro populations of North Africa by any other observer.
595 individuals.
${ }^{3} 698$ individuals.
${ }^{4}$ Of 349 individuals.

${ }^{5} 33$ individuals.

- Of 42 individuals. 
COMPARISON OF THE MEASUREMENTS OF THE KHARGA MEN WITH THOSE OF SOUDANESE AND OTHER NEGROES

\begin{tabular}{|c|c|c|c|c|}
\hline Peoples (males) & $\begin{array}{l}\text { Kharga } \\
\text { Oasis }\end{array}$ & $\begin{array}{l}\text { Negroes: } \\
\text { Nilotic } \\
\text { group }\end{array}$ & $\begin{array}{l}\text { Negroes: } \\
\text { Nubian } \\
\text { group }\end{array}$ & $\begin{array}{l}\text { Negroes: } \\
\text { American } \\
\text { (full blood) }\end{array}$ \\
\hline Observers & Hrdlička & Chantre & Chantre & Hrdlicka \\
\hline Number of cases..... & I 50 & 35 & 26 & 20 \\
\hline Mean age, years...... & 40 & $\ldots \ldots$ & & 36.2 \\
\hline Stature, $\mathrm{cm} . . . \ldots \ldots \ldots \ldots \ldots \ldots \ldots$ & I63.8 & $\mathrm{I} 74 \cdot \mathrm{I}$ & 169.0 & I68.6 \\
\hline $\begin{array}{l}\text { Height sitting, per cent of total height } \\
\text { Head: }\end{array}$ & $51 \cdot 26$ & $\cdots \cdots$ & $\cdots \cdots$ & $5 \mathrm{I} \cdot 43$ \\
\hline 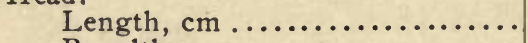 & I8.9 & I8.94 & I 8.98 & I9.6 \\
\hline 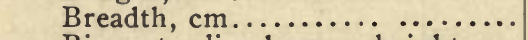 & $I 4 \cdot I$ & 13.95 & $\mathrm{I} 4 \cdot \mathrm{I}$ & I 5.0 \\
\hline $\mathrm{Bi}$-meatus line-bregma height, $\mathrm{cm}$ & I $3 \cdot 2$ & & & $13 \cdot 5$ \\
\hline 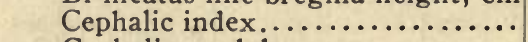 & 74.9 & 73.66 & $\ddot{74.53}$ & 76.3 \\
\hline $\begin{array}{l}\text { Cephalic module, } \mathrm{cm} \text {. } \\
\text { Per mille relation of cephalic mod- }\end{array}$ & $15 \cdot 4$ & $\cdots \cdots$ & ...... & 16.0 \\
\hline 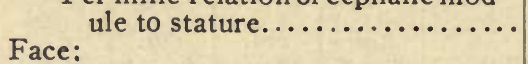 & $94 \cdot 0$ & & & $95 \cdot 0$ \\
\hline 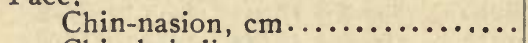 & II $\cdot 35$ & & & II $\cdot 9$ \\
\hline Chin-hair line, $\mathrm{cm} . . . .$. & 17. & $\ldots \ldots$ & ...... & 17.95 \\
\hline Height of forehead, cm.......... & & ...... & ...... & 6.05 \\
\hline Diam. bizygomatic max., cm..... & I3. I 5 & I3.3 & $13 \cdot 26$ & 13.97 \\
\hline Facial index, physiognomic ...... & 86.3 & & & 85.1 \\
\hline Facial index, anatomic ........... & 74.7 & & .. & 73.5 \\
\hline Nose: & & & & \\
\hline $\begin{array}{l}\text { Height, } \mathrm{cm} \ldots \ldots \ldots \ldots \ldots \ldots \ldots \ldots \ldots \\
\text { Breadth, }{ }^{\prime} \ldots \ldots \ldots \ldots \ldots \ldots \ldots\end{array}$ & 4.87 & $4 \cdot 08$ & $4 \cdot 2$ & $4 \cdot 9$ \\
\hline 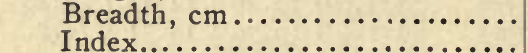 & $3 \cdot 73$ & $4 \cdot 3$ & $4 \cdot 42$ & $4 \cdot 57$ \\
\hline $\begin{array}{l}\text { Index............. } \\
\text { Diam. frontal mi }\end{array}$ & & 105.4 & 105.0 & 92. \\
\hline Diam. bigonial, $\mathrm{c}$ & & ...... & $\cdots \cdots$ & 10.6 \\
\hline 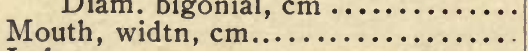 & $10 \cdot 3$ & $\cdots \cdot \cdot$ & $\cdots \cdots$ & 10.8 \\
\hline Left ear: & 5. & $5 \cdot 3$ & $5 \cdot 2$ & $5 \cdot 7$ \\
\hline Height, $\mathrm{cm} . . . . .$. & $6 \cdot 3$ & ...... & ..... & $5 \cdot 99$ \\
\hline Breadth, cm....... & $3 \cdot 7$ & $\cdots \cdots$ & ...... & 3.69 \\
\hline 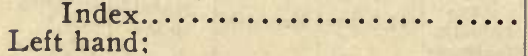 & 58.9 & & $\cdots \cdots$ & 61.6 \\
\hline Length, $\mathrm{cm} \ldots \ldots \ldots \ldots \ldots$ & 19.0 & ...... & ...... & 20.0 \\
\hline Breadth, cm.............. & 8.8 & ..... & $\cdots \cdots$ & $9 \cdot 15$ \\
\hline $\begin{array}{l}\text { Index............ } \\
\text { Left foot: }\end{array}$ & 46.3 & & $\cdots \cdots$ & 45.7 \\
\hline Length, $\mathrm{cm} \ldots \ldots \ldots \ldots$ & & & & 26.8 \\
\hline Breadth, cm.............. & 10.0 & ...... & ...... & $10 \cdot 3$ \\
\hline Index $\ldots \ldots \ldots \ldots \ldots \ldots \ldots$ & 39.4 & ...... & ...... & 38.3 \\
\hline Left leg, circumference, $\mathrm{cm}$......... & 32.0 & ..... & ..... & 36.9 \\
\hline
\end{tabular}

\section{CONCLUSIONS}

The Kharga Oasis Egyptians are people in general of somewhat subnormal physical development, due principally to long lasting defective nutrition.

The majority of the people are as yet but little mixed with the negro. 
Those who are not mixed with the blacks, show a fairly uniform physical type. This type is characterized by medium brown skin, horizontal brown eye, black and straight hair (with a tendency to wave when longer), black, straight, wavy or slightly curly and often scanty beard, moderate stature, dolicho- to mesocephalic and medium high head, oblong and meso- to orthognathic face, mesorhinic nose, rather long and narrow ear, and moderately proportioned chest, pelvis, hands and feet. They give somewhat higher pulse and respiration than the average in whites, but perecptibly lower temperature, and decidedly lower muscular force.

The type of the Kharga natives is radically distinct from that of the negro. It is according to all indications fundamentally the same as that of the non-negroid Valley Egyptians. It is in all probability a composite of closely related northeastern African and southwestern Asiatic, or "hamitic" and "semitic" ethnic elements, and is to be classed with these as part of the southern extension of the Mediterranean subdivision of the white race.

Judging from the mummies of the Oasis inhabitants from the 2-5 centuries A. D., exhumed at El Baguat, the type of the present non-negroid Kharga natives is substantially the same as that of the population of the Oasis during the first part of the Christian era. The nature of the population of the Oasis in more ancient times can only be determined by skeletal material from the ancient cemeteries.

In order to facilitate the general use or more extended analysis of the data, the detailed measurements are appended. There is also added a bibliography relating or referring to the Kharga Oasis population. 


\section{BIBLIOGRAPHY RELATING OR REFERRING TO THE KHARGA OASIS POPULATION}

(For older bibliography see works cited in the text.)

Ball, J. Kharga Oasis: Its Topography and Geology. Public. of the Survey Dept., Cario, I900 (on cover = "Geological Survey Report, I899”). I vol. $8^{\circ}$. Gives archeological survey (locations), also population statistics and bibliography.

Beadnell, H. J. L. An Egyptian Oasis. $8^{\circ}$, London, 1909. General observations on the Kharga Oasis people. Census data.

- The Oases and the Geology of Egypt. In "The Nile in 1904," by Sir Wm. Willcox. $8^{\circ}$, London, 1904 .

Beau de Rochas, A. Oasis et Soudan. I vol. gr. in $8^{\circ}$, Paris, I888, pp. I-64.

Browne, W. G. Travels in Africa, Egypt, Syria. $4^{\circ}$, 2d ed., London, 1806. Kharga $=$ p. 197 et seq. Observations on Dar-Fur. Speaks of the caravan from Assiut across the Oasis to Dar-Fur, and of acquisition of slaves by the Oasis people-nothing at all about people themselves.

Brugsch Bey, H. A History of Egypt. 2d. ed., 2 vol. $8^{\circ}$, London, I88I. Banishment to the Gr. Oasis during the XXI Dyn. vol. II, 201, 203.

Reise nach dem grossen Oase el Khargeh in der Libyschen Wüste, 1878 .

Caillaud, F. Voyage à l' oasis de Thèbes et dans les déserts situés à l'orient et à l'occident de la Thébaïde, fait pendant les années I8I5 à I818. Rédigé et publié par Jomard. Paris, Imprimerie Royale, I82I-I862, 2 vol. gr. in folio, en feuilles.

Drovetri. Itinerary of an Excursion to the Valley of Dakel. New Voyages and Travels, Vol. 7, London, 1822.

Edmondstone, A. A Journey to Two of the Oases of Upper Egypt. $8^{\circ}$, London, 1822. Contains references to ancient writers who mentioned the Oasis-but little of value. No personal observations on the people.

GolenischefF.

Guest, A. R. The Oases of the Mudirieh of Assyut. Geogr. Journ., Vol. I6, London, I900.

Herodotus. Thalia.

Hoskins, G. A. Visit to the Great Oasis of the Libyan Desert. $8^{\circ}$, London, 1837. Limited notes on the Kharga people-nothing of great importance.

Hume, W. F. The South-Western Desert of Egypt. The Cairo Scientific Journal, Vol. 2, August-Sept., I908.

De Morgan, J. Recherches sur les origines de $1^{\prime}$ Egypte. . $8^{\circ}$, Paris, 1897. "Paleoliths" found on the Oasis and between it and Abydos.

Lyons, H. G, Notes sur le Géographie physique des Oasis de Khargueh et de Dakhẹl. Bull. Soc. Khéd. de Géogr., Fourth Series, No. 4, Cario, I894.

Maspero, G. Histoire ancienne des peuples de l'Orient classique. 3 vol. in gr. $8^{\circ}$, Paris, Vol. I. 1895; Vol. 2, I897; Vol. 3, 1908. References to Oasis of Kharga I, 43I-432, VIth Dyn., Hirkhouf's expedition. Nothing more than Breasted. 
Quatremère, E. Mémoires géographiques et historiques sur l' Egypte, et sur quelques contrées voisines. 2 vol. in $8^{\circ}$., Paris, I8Ir. Gives all known about the "Blemmyes"-Vol. 2; Nothing on the Oasis except mention of its devastation by the Blemmyes.

Savary, C. E. Lettres sur l'Egypte. 3 vol. in $8^{\circ}$., I777. English translation, 2 vol., $8^{\circ}$., London, 1887. Mention in Vol. 2 the fact of exiles being sent to the Oases, but nothing on inhabitants.

Sayce, A. H. History of the Egyptian Oases. The Egyptian Gazette, April 6, 1905.

Schweinfurth, G. Notizen zur Kenntniss der Oase El-Chargeh. Petermann's Mittheilungen, Vol. 21, 1875, Heft 1o, pp. 384-393. Notes on archaeological remains of the Oasis, including E1 Baguat. Nothing on the people or their history.

ZitreL, K. Beitrage zur Geologie and Palaeontologie der Libyschen Wüste. Rohlfs'sche Expedition. 8vo., Cassel, 1883. 


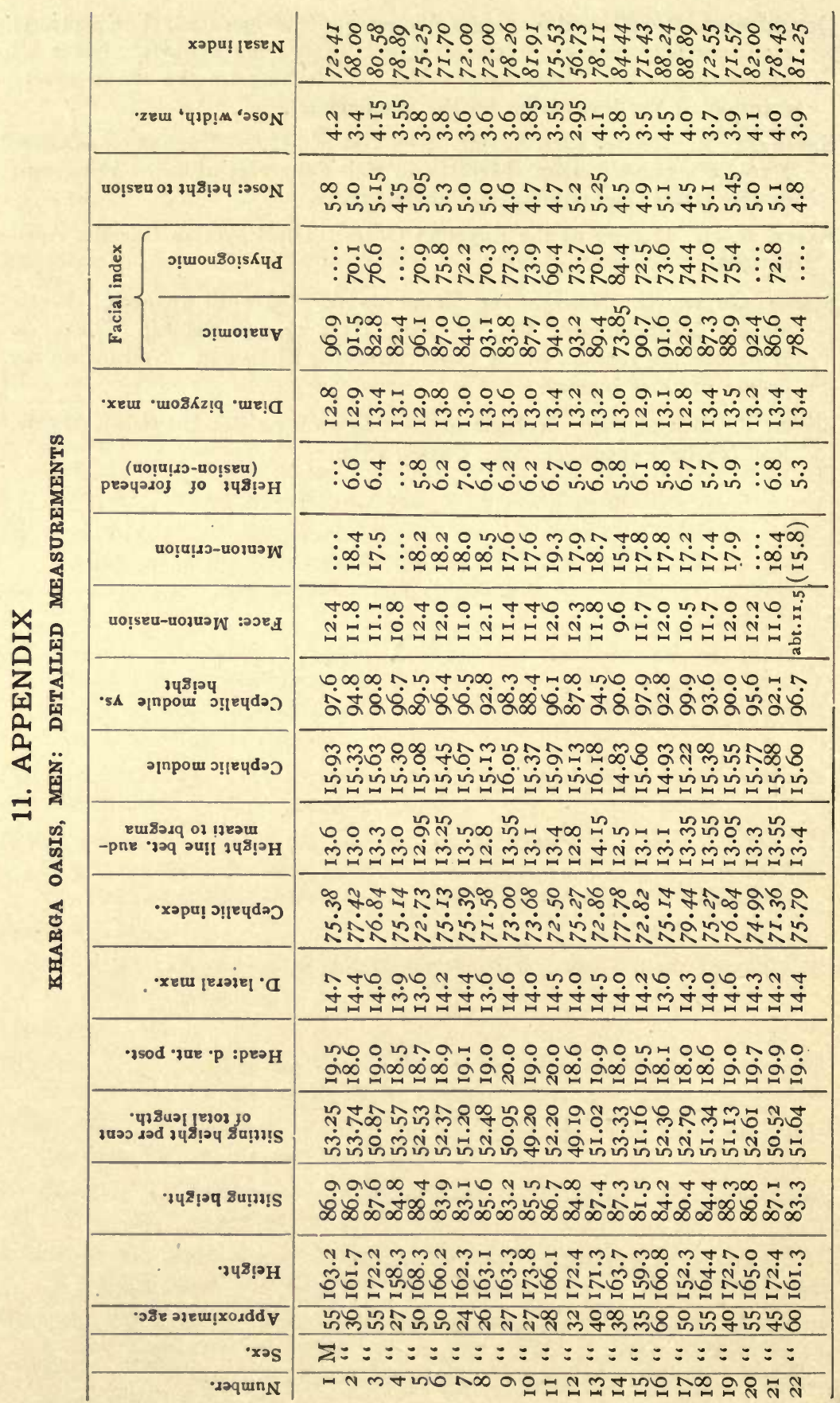




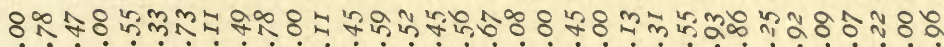

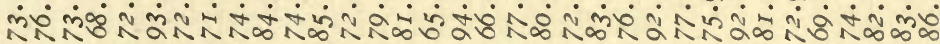

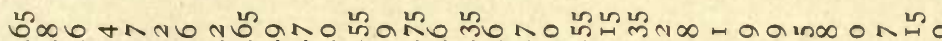

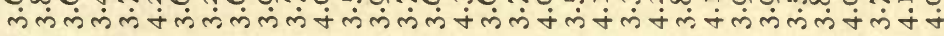

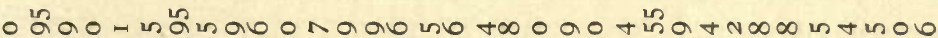

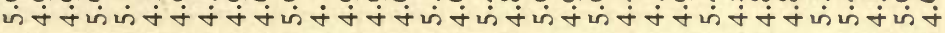

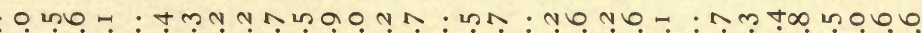

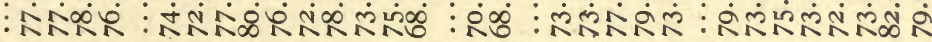

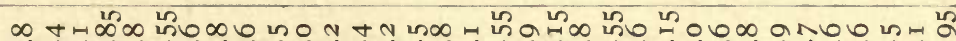

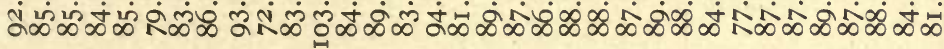

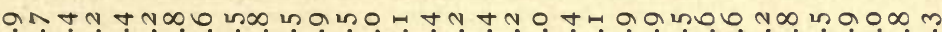

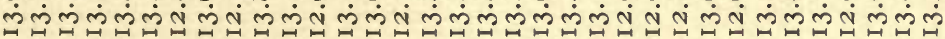

:

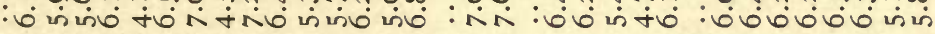

$: \infty$ mon - iNO

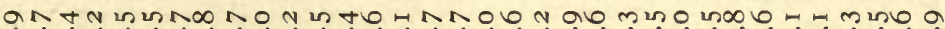

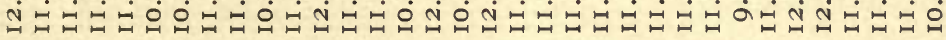

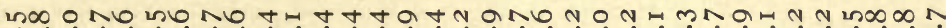

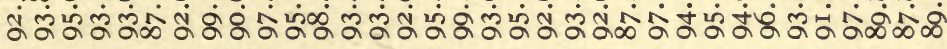

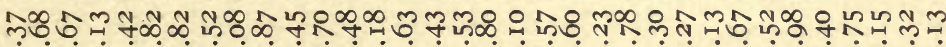
ம்ம்ம்ம்

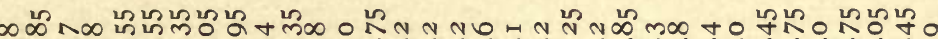

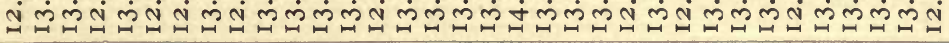

柿政

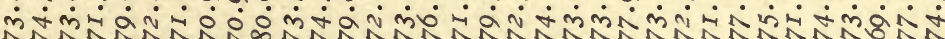

NRNARNANOR

\#?

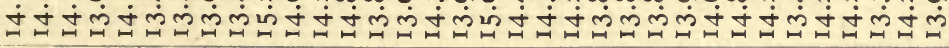

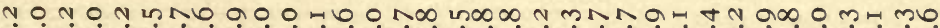

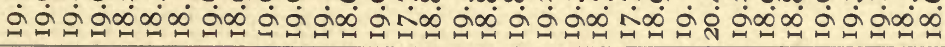

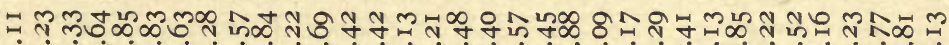

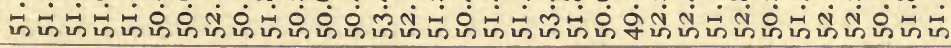

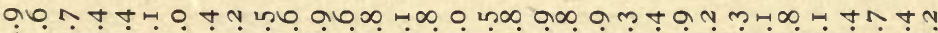
ஈ

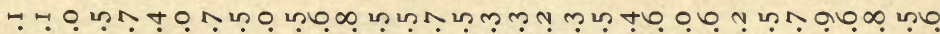

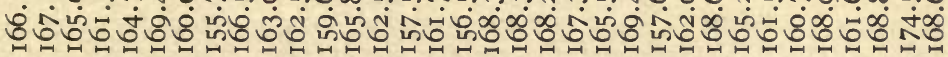

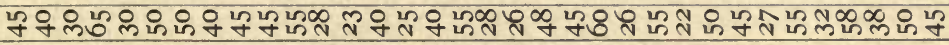

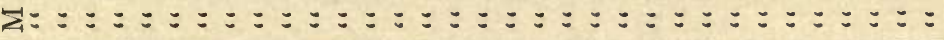

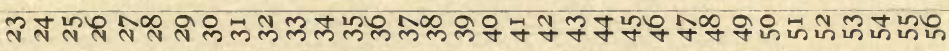




\begin{tabular}{|c|c|}
\hline 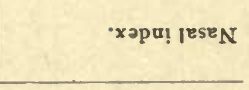 & रंฌ \\
\hline •xеนи 'чวр!м ‘วsоN & 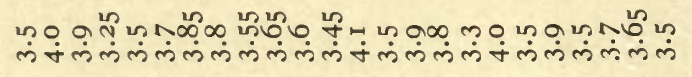 \\
\hline 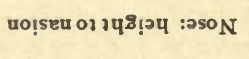 & 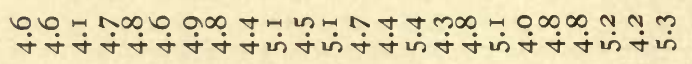 \\
\hline 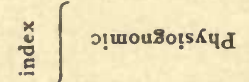 & 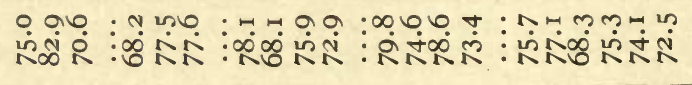 \\
\hline 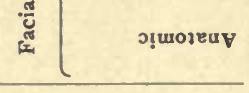 & 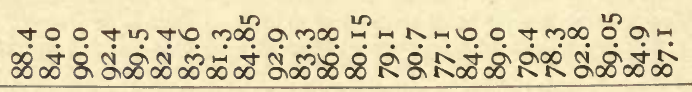 \\
\hline 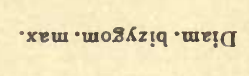 & 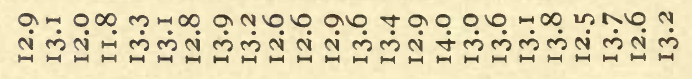 \\
\hline 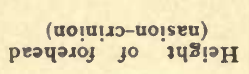 & 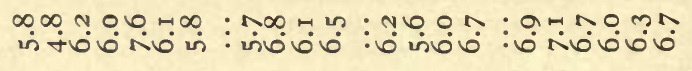 \\
\hline 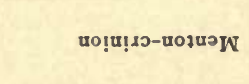 & 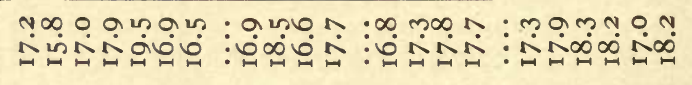 \\
\hline 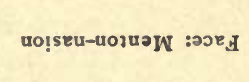 & +o \\
\hline 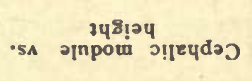 & 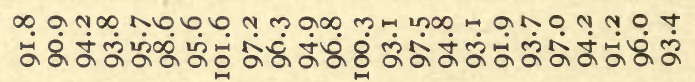 \\
\hline 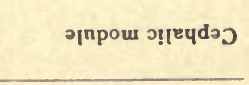 & 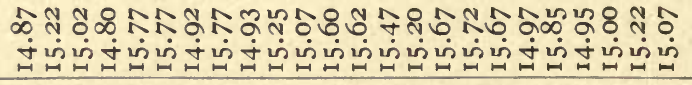 \\
\hline 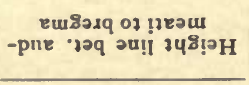 & 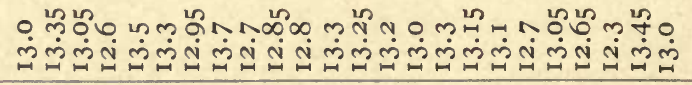 \\
\hline xəрu!̣ ग!โยчdəว & 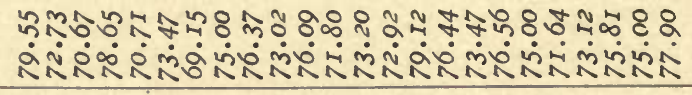 \\
\hline 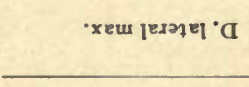 & 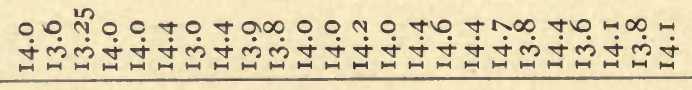 \\
\hline -gsod • зue 'p :реәH & 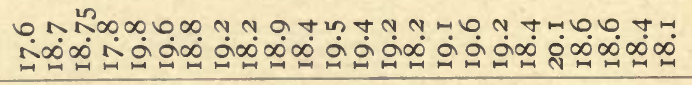 \\
\hline 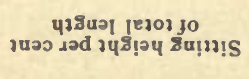 & 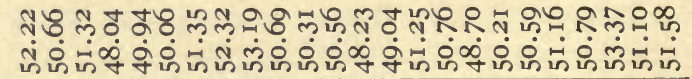 \\
\hline 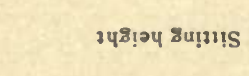 & 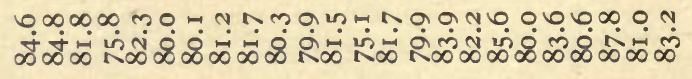 \\
\hline วчริเอ & 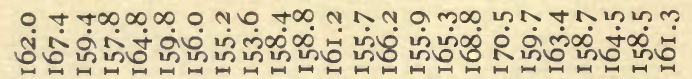 \\
\hline 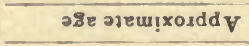 & 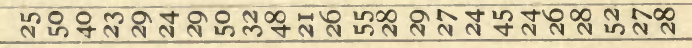 \\
\hline XOS & $+:=:=:=:=:=:=:=:=:=:=:=$ \\
\hline sPqun $N$ & 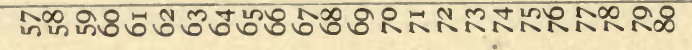 \\
\hline
\end{tabular}




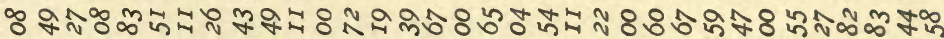

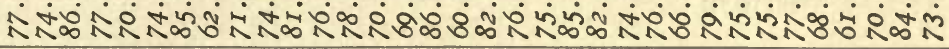

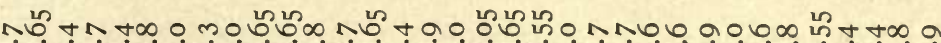

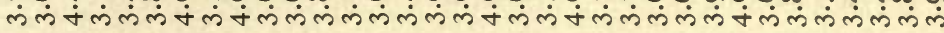

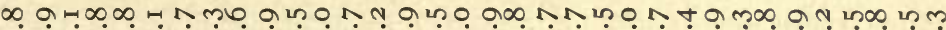

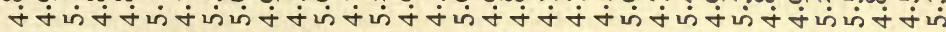

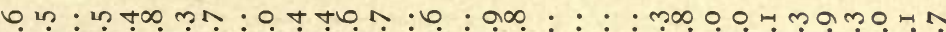
ヘ் : mกดN

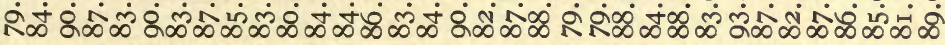

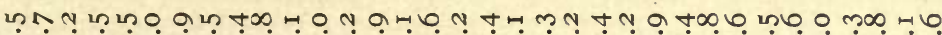

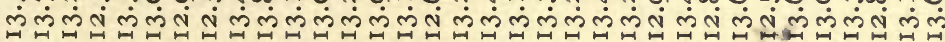

no:

ம் : ம்

t+

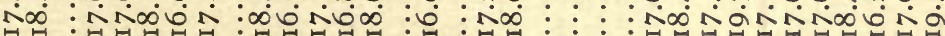

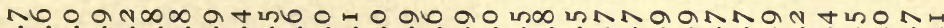

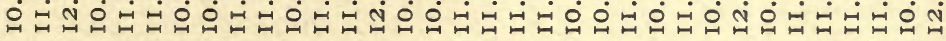

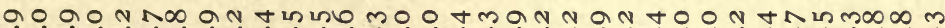

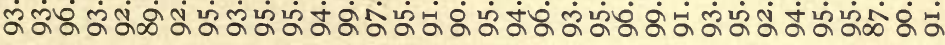

ูํํำ

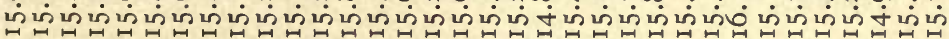

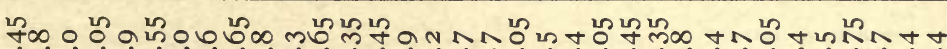

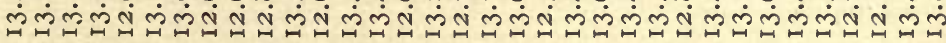

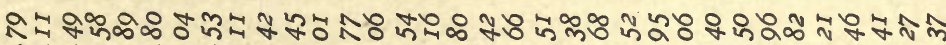
ம்கள்

+

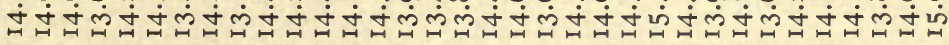

O

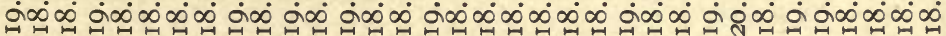

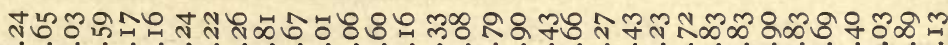
ㅇํㅇํำ

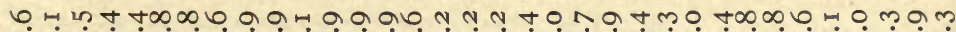

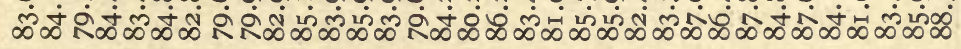

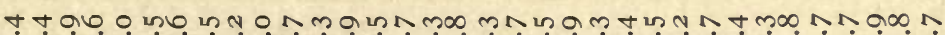
రి 서은

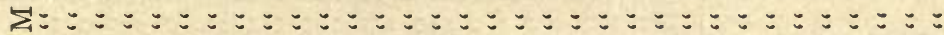
ஈ 


\begin{tabular}{|c|c|}
\hline xәри! ןeseN & nis. \\
\hline - хеш ' "ұрр!м 'әsо $\mathrm{N}$ & 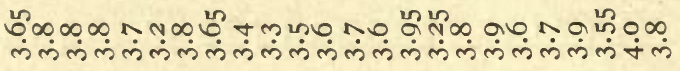 \\
\hline 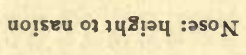 & 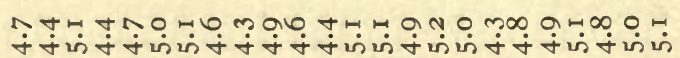 \\
\hline 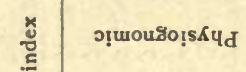 & 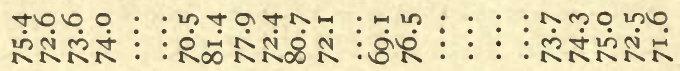 \\
\hline ग!ณовยน & 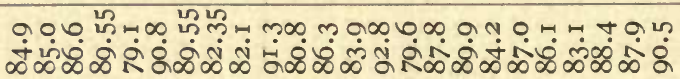 \\
\hline 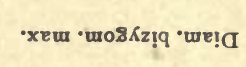 & 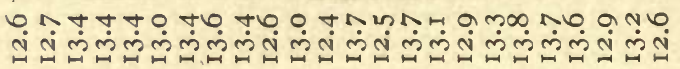 \\
\hline 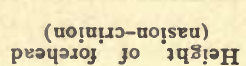 & 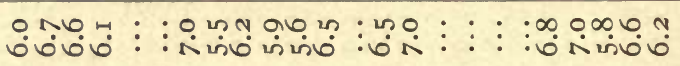 \\
\hline 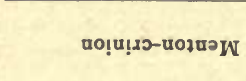 & 수움유 : \\
\hline 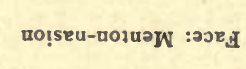 & 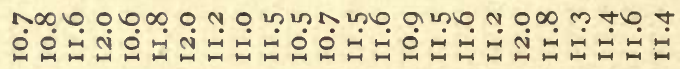 \\
\hline 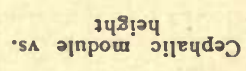 & 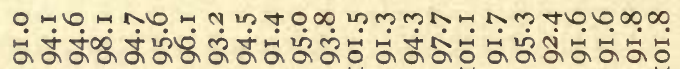 \\
\hline 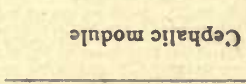 & 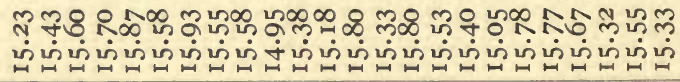 \\
\hline 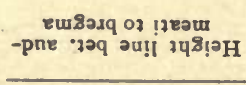 & 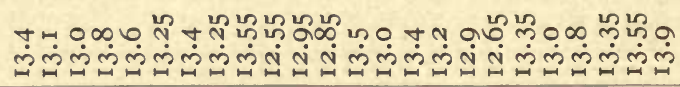 \\
\hline 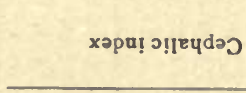 & 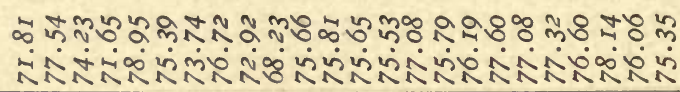 \\
\hline 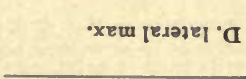 & 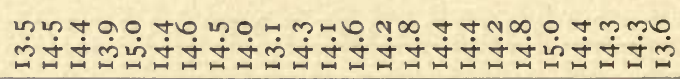 \\
\hline$\cdot 3$ sod $\cdot z$ ue $\cdot p$ :prosh & 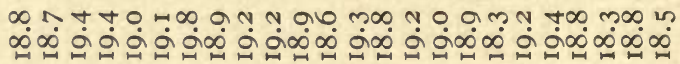 \\
\hline 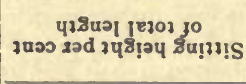 & 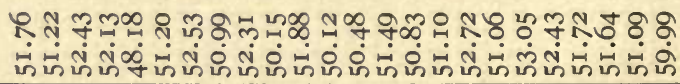 \\
\hline 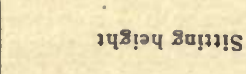 & 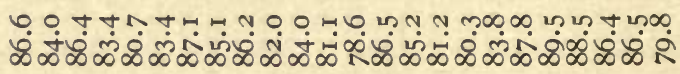 \\
\hline วบ8ฺฺว $\mathrm{H}$ & 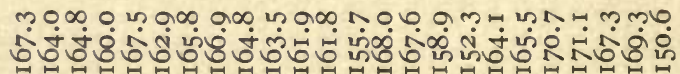 \\
\hline 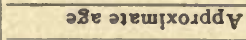 & 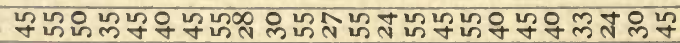 \\
\hline xas & $\Sigma:=::=::=:=:=:=:=:=::=:=$ \\
\hline soquin $_{\mathbf{N}}$ & \\
\hline
\end{tabular}




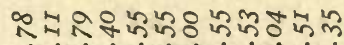

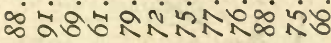

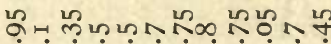

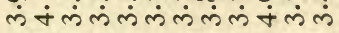

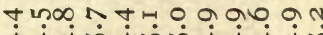

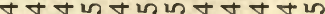

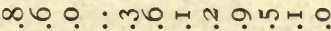

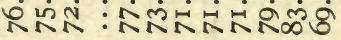

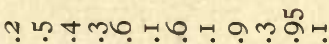
வு க் ட் ம்

ด m

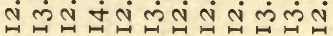

กรก: ดें :

$\infty 0 \infty$ : ? ๆ 업어:

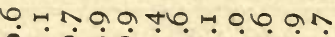

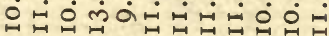

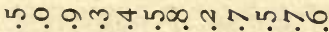

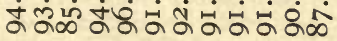

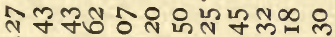
ம்ம் ம்ம்ம்ம்ம்ம்

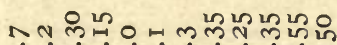

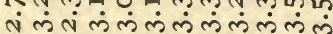

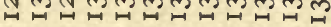

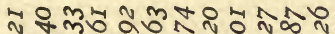

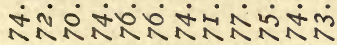

man

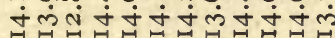

o N N m HOHNON

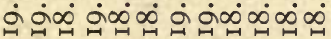

88000 Ұ

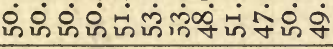

aн mo † थ

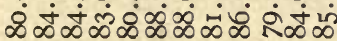

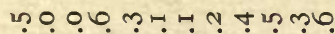

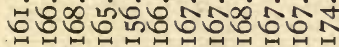

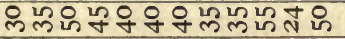
$\Sigma:=:=:=::=:=$

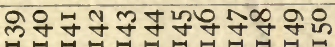




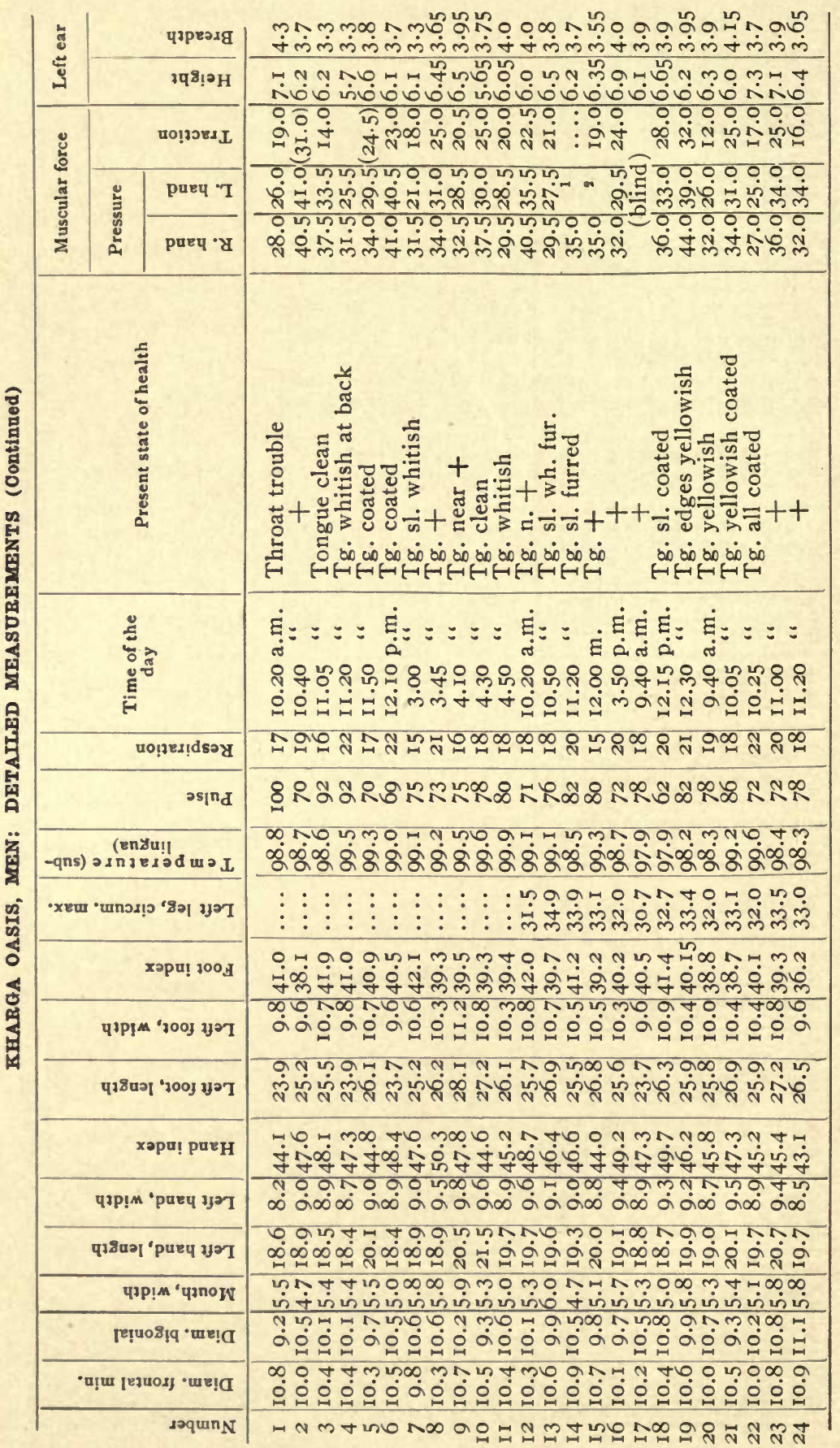




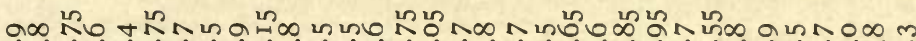

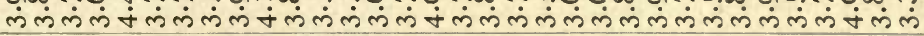

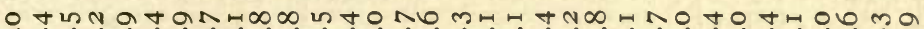

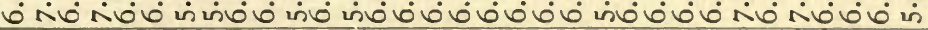

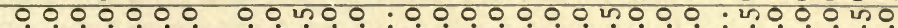

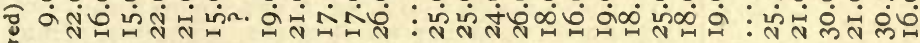
站 :000.

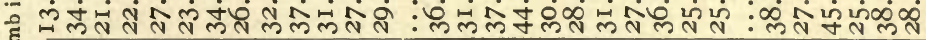

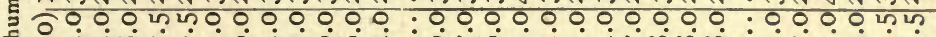
こ

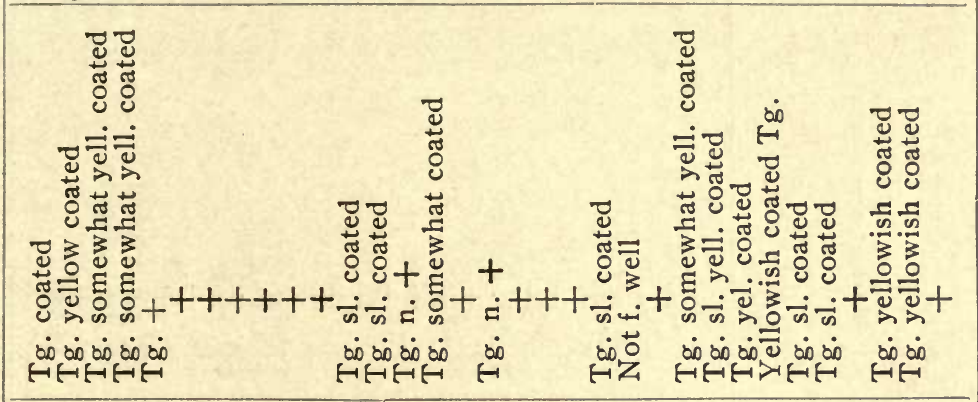

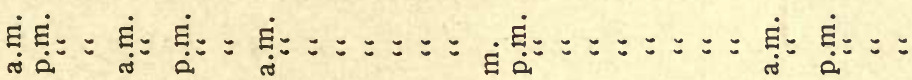

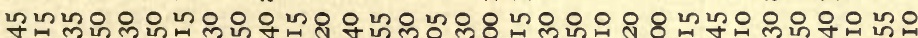

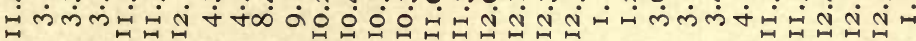

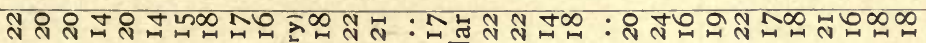
แัด

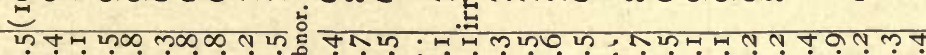
sंso

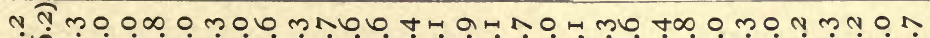

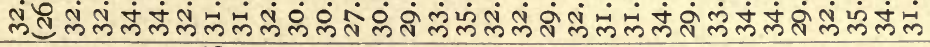
ก +

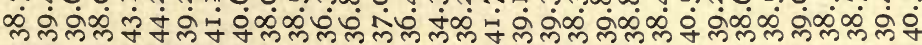

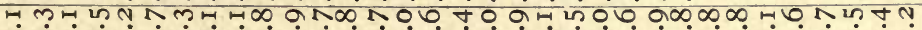

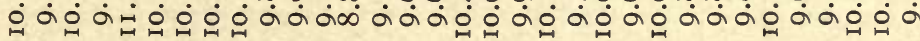

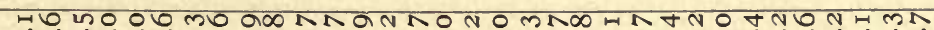
बै

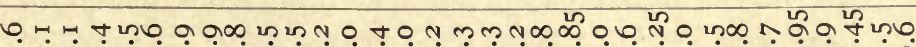

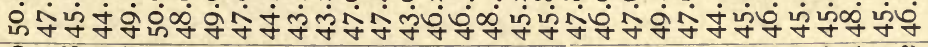
and mतn

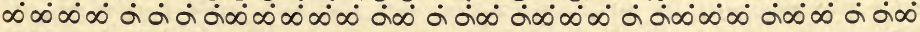

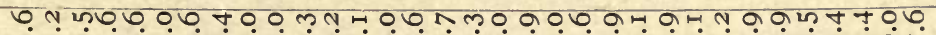

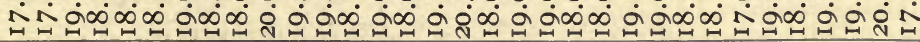

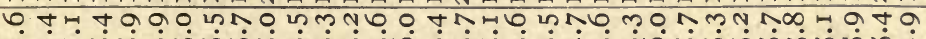

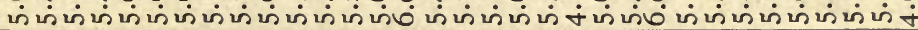
4

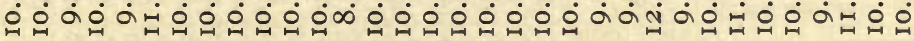

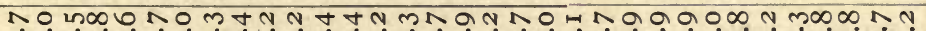

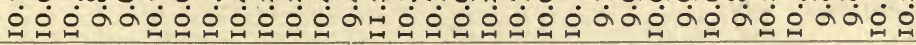

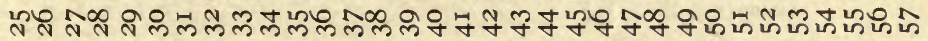




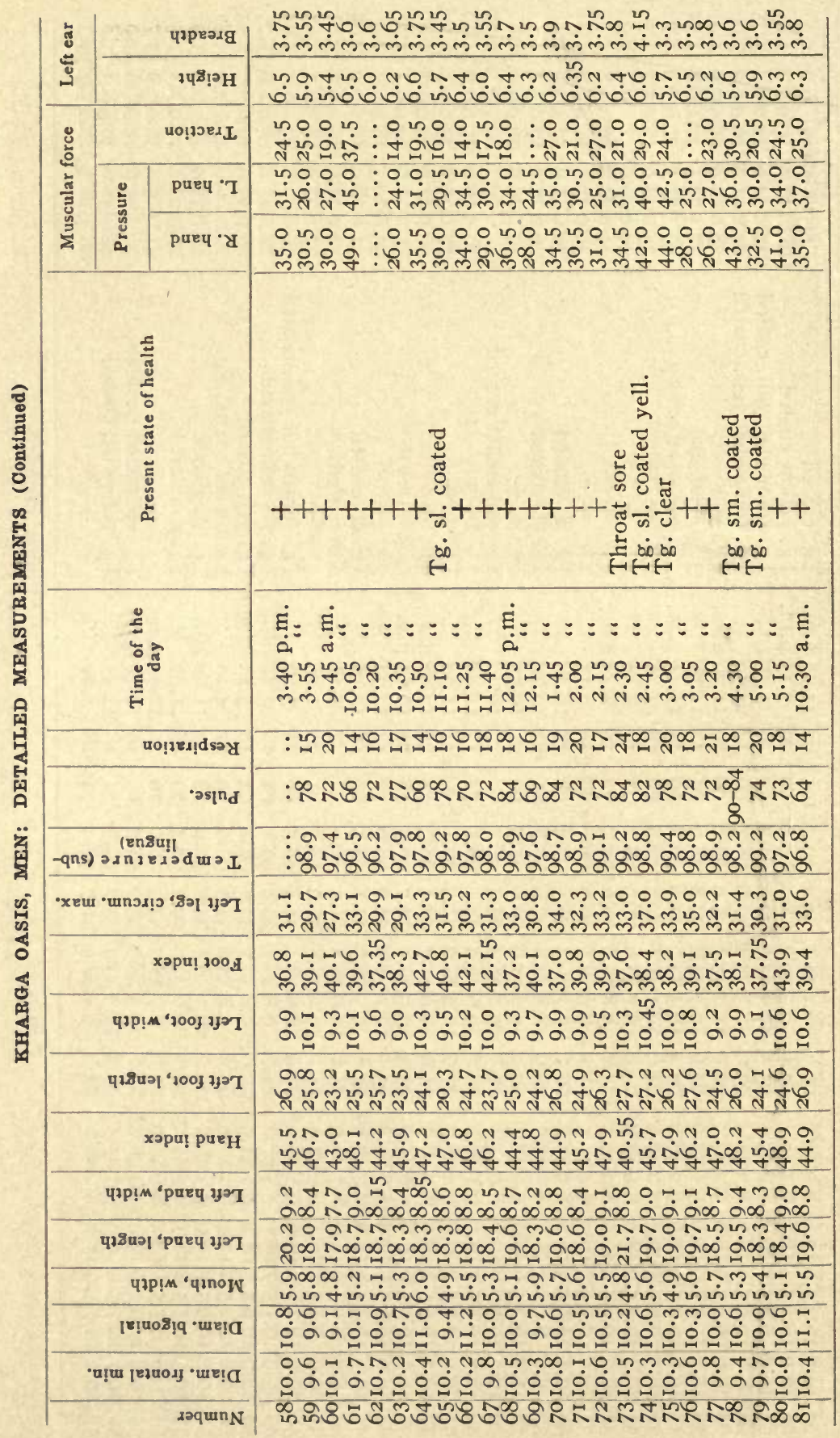




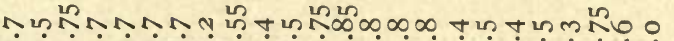

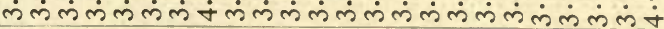

N ல் ம்ல்ல்

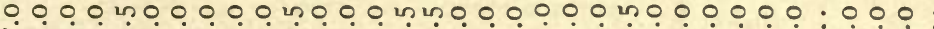
กल 0 n 00000000000 n $00:$ : 00000000 n 00 : 000 :

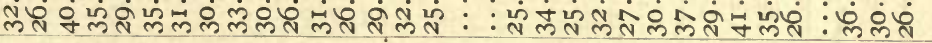

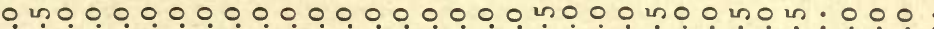
लं尺्र

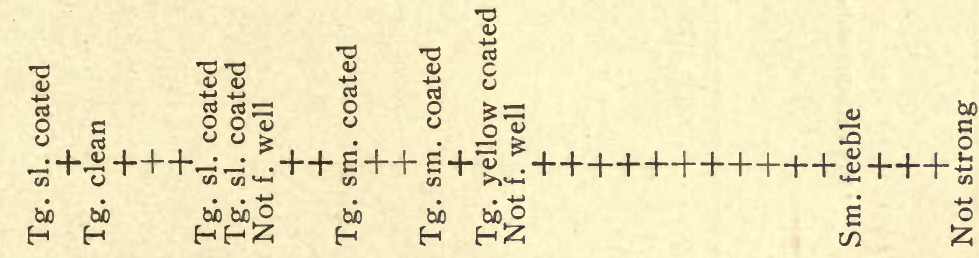

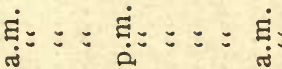

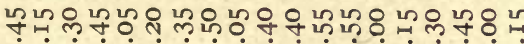

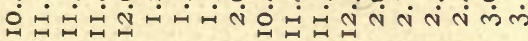

내에

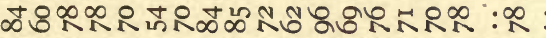

ดNッดルNN

कूँ

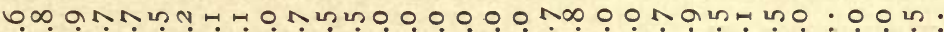

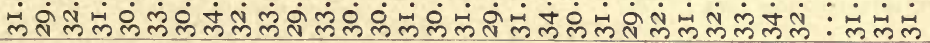

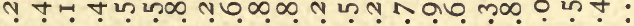

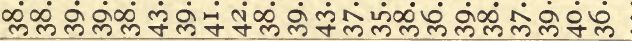

$0 \infty \because m$ n?

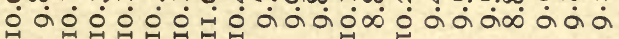

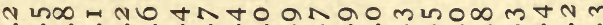

तु भु

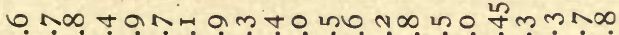

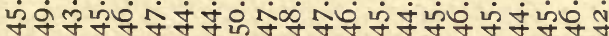

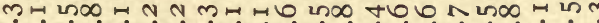

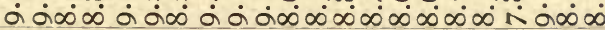

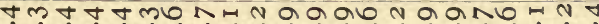

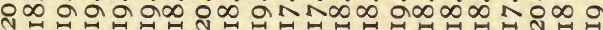

4N mo,

ம

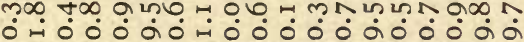

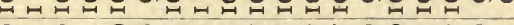

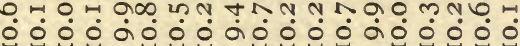

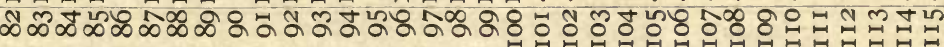




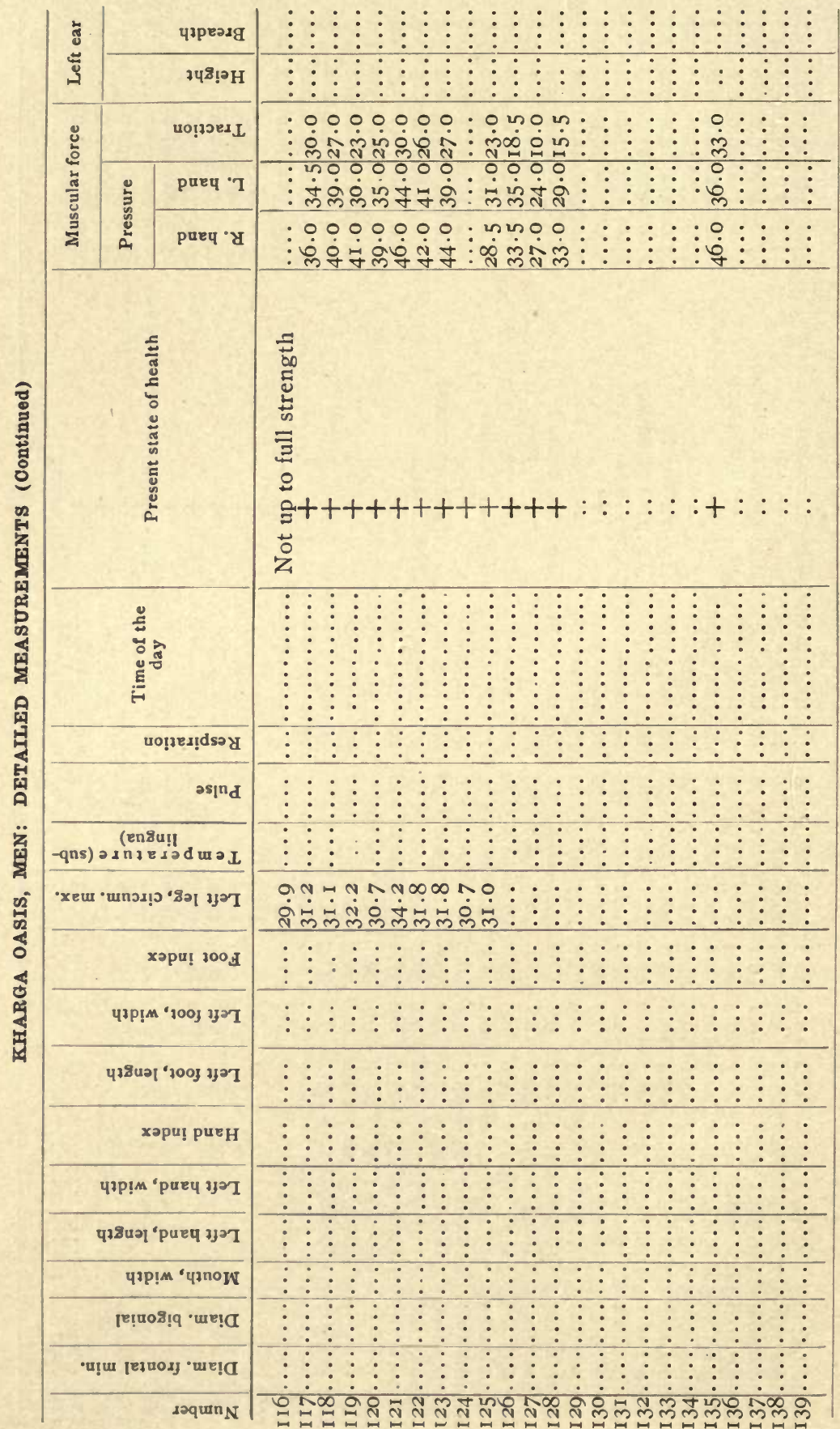




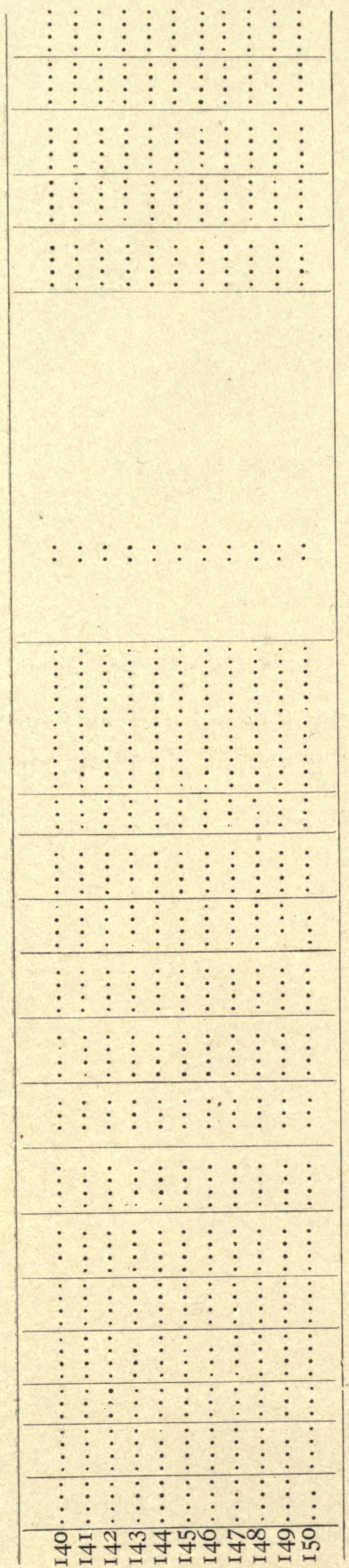


The following series of plates illustrate the Kharga natives from the nearly adult to the aged, showing the principal physiognomic variations. 


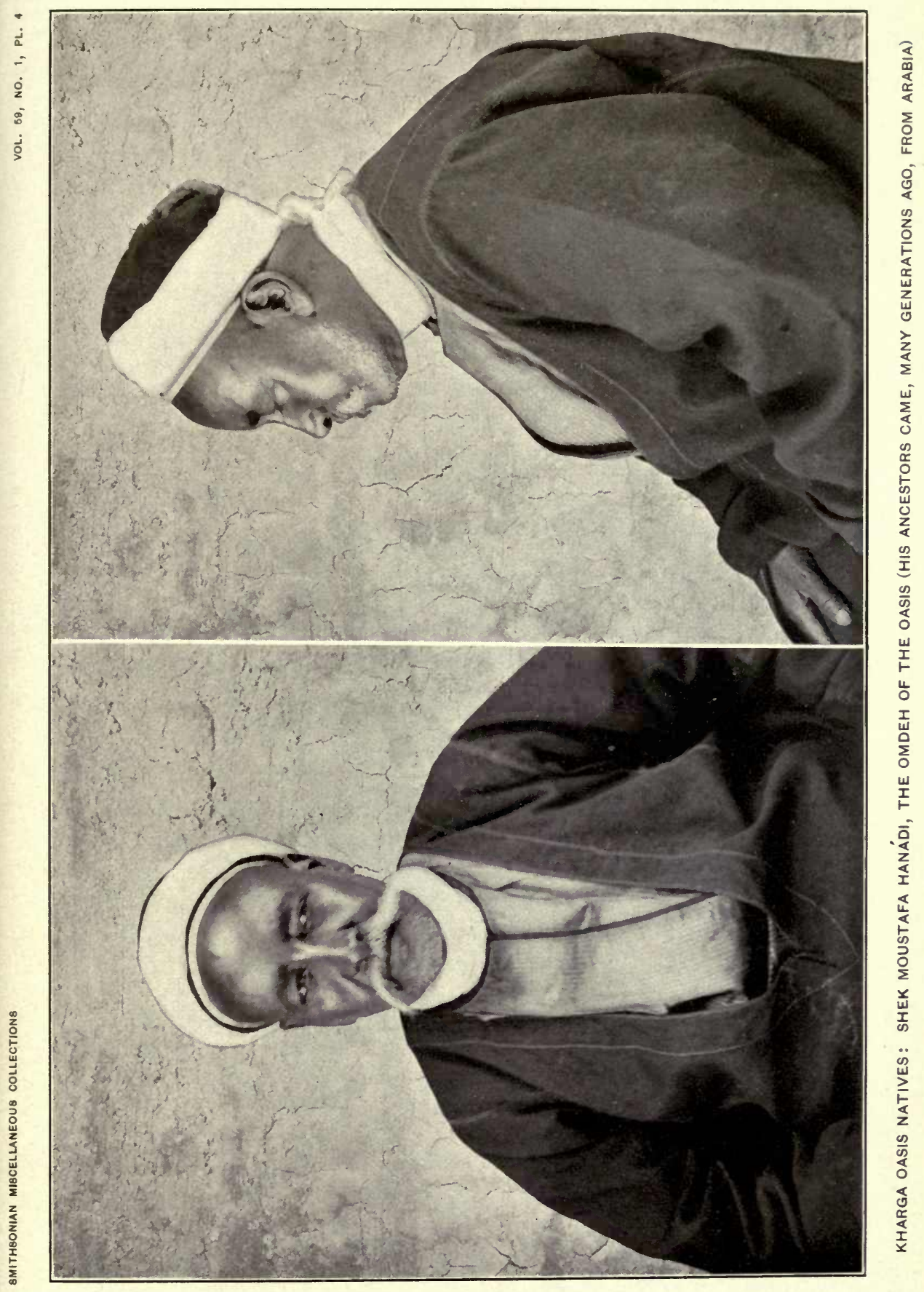




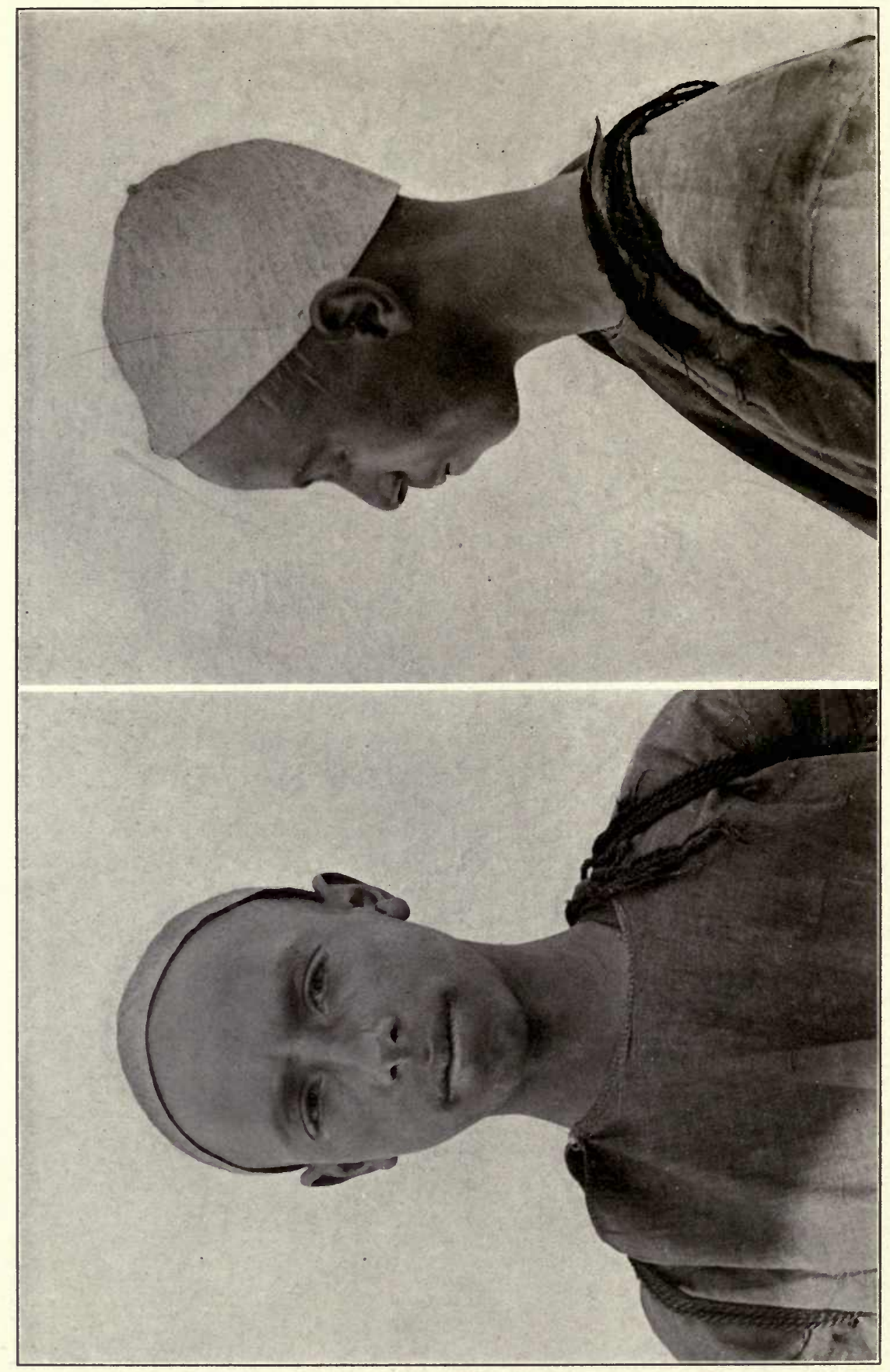

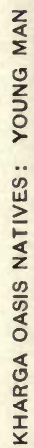




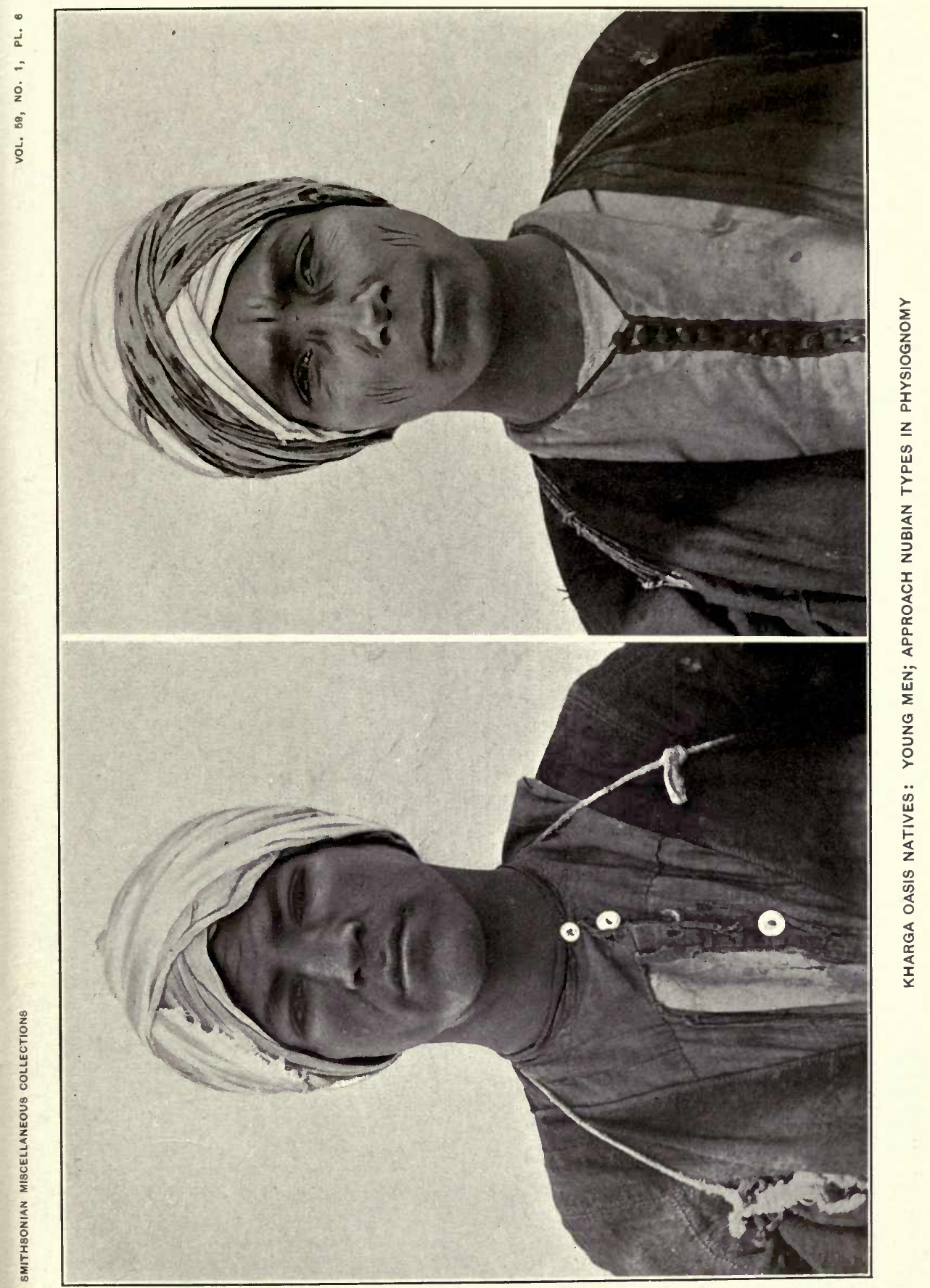




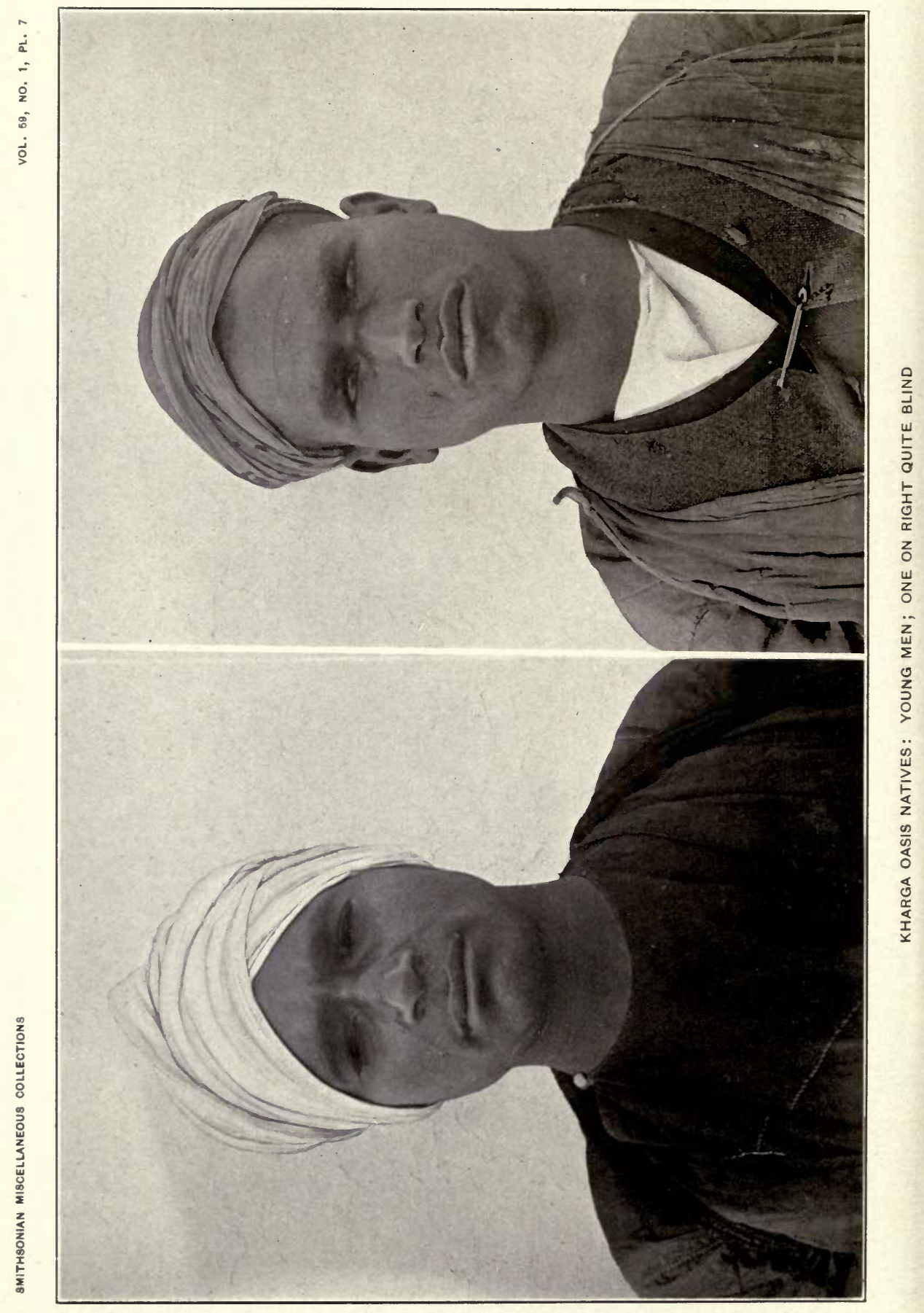




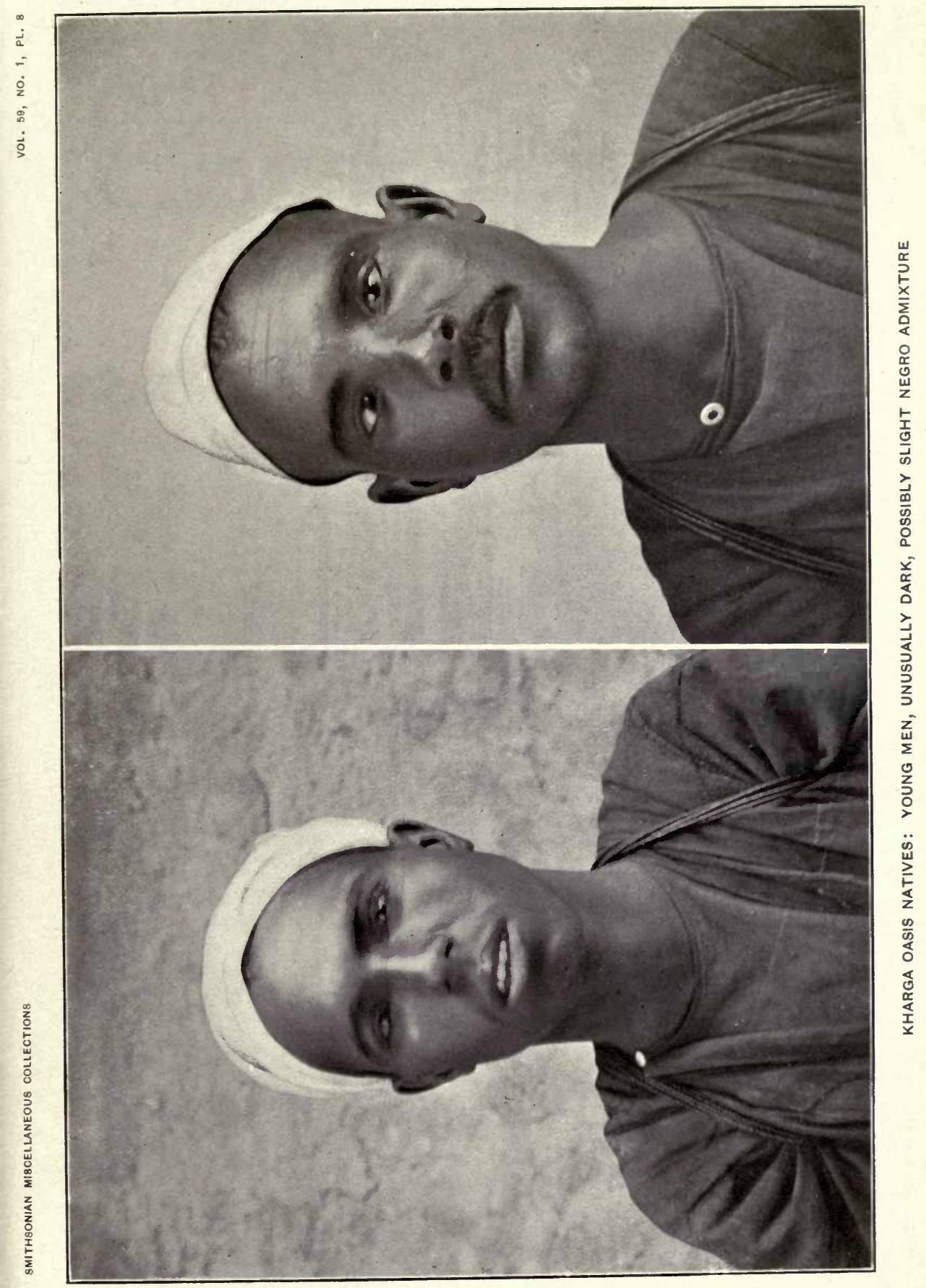




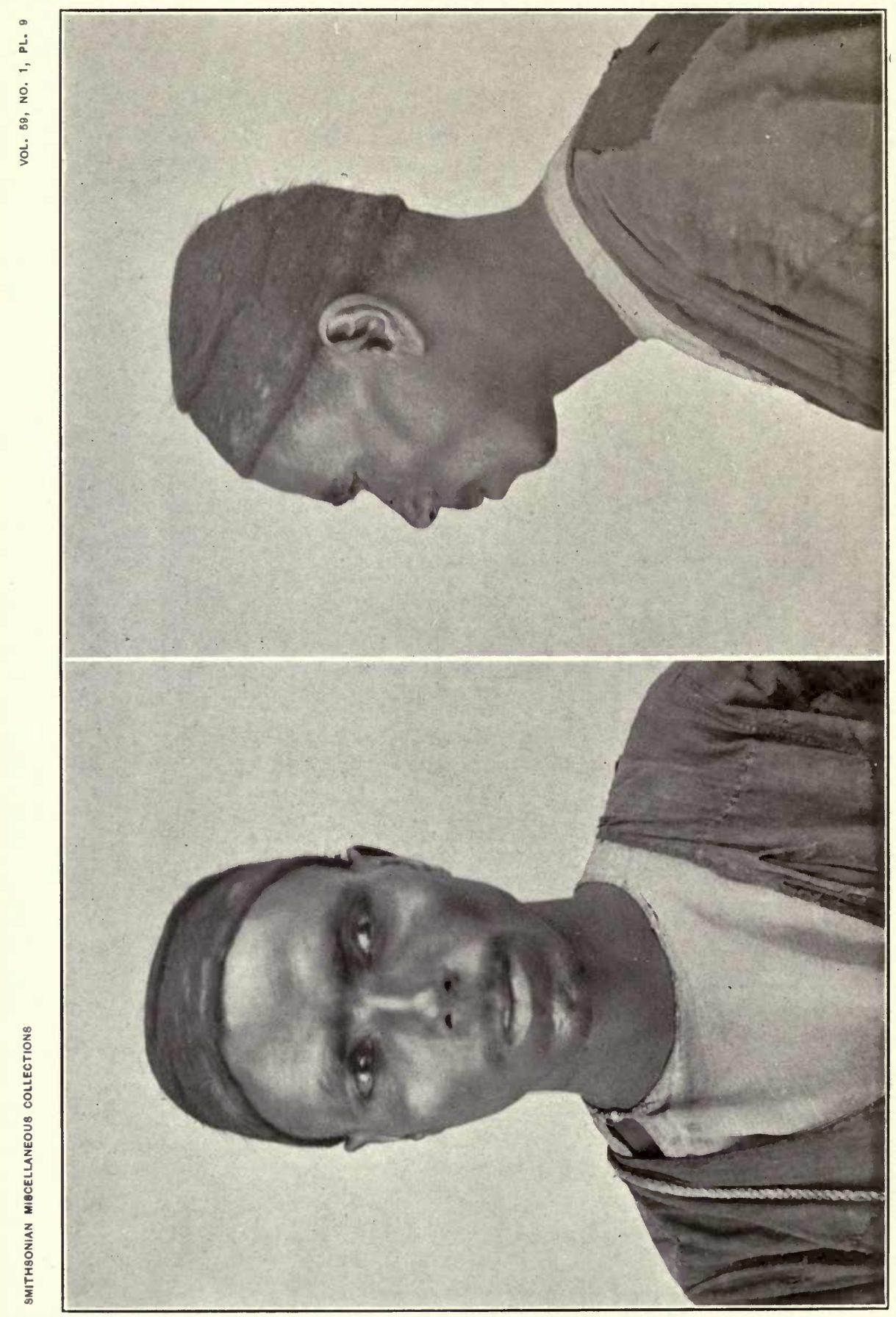

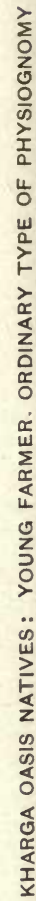




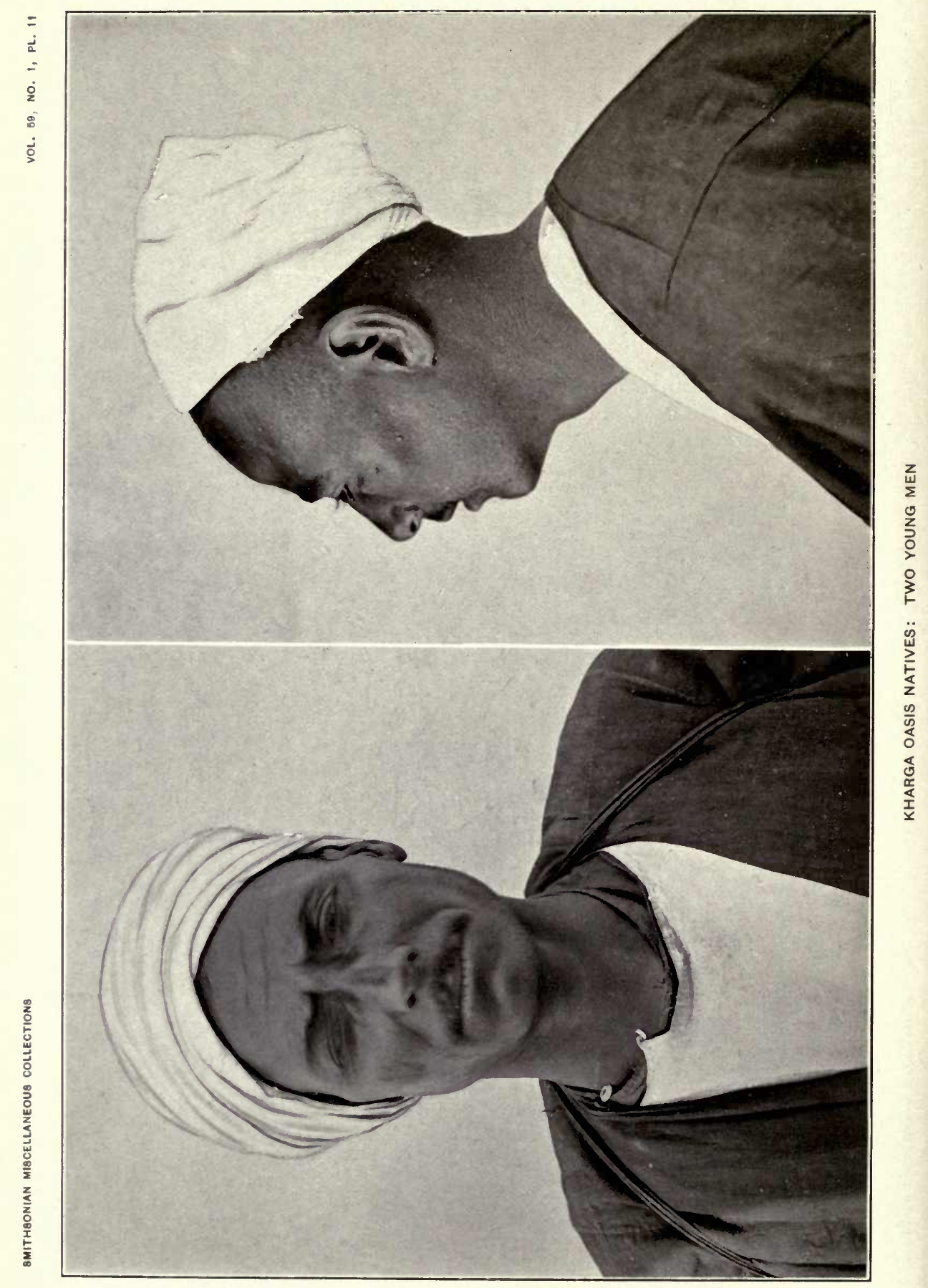




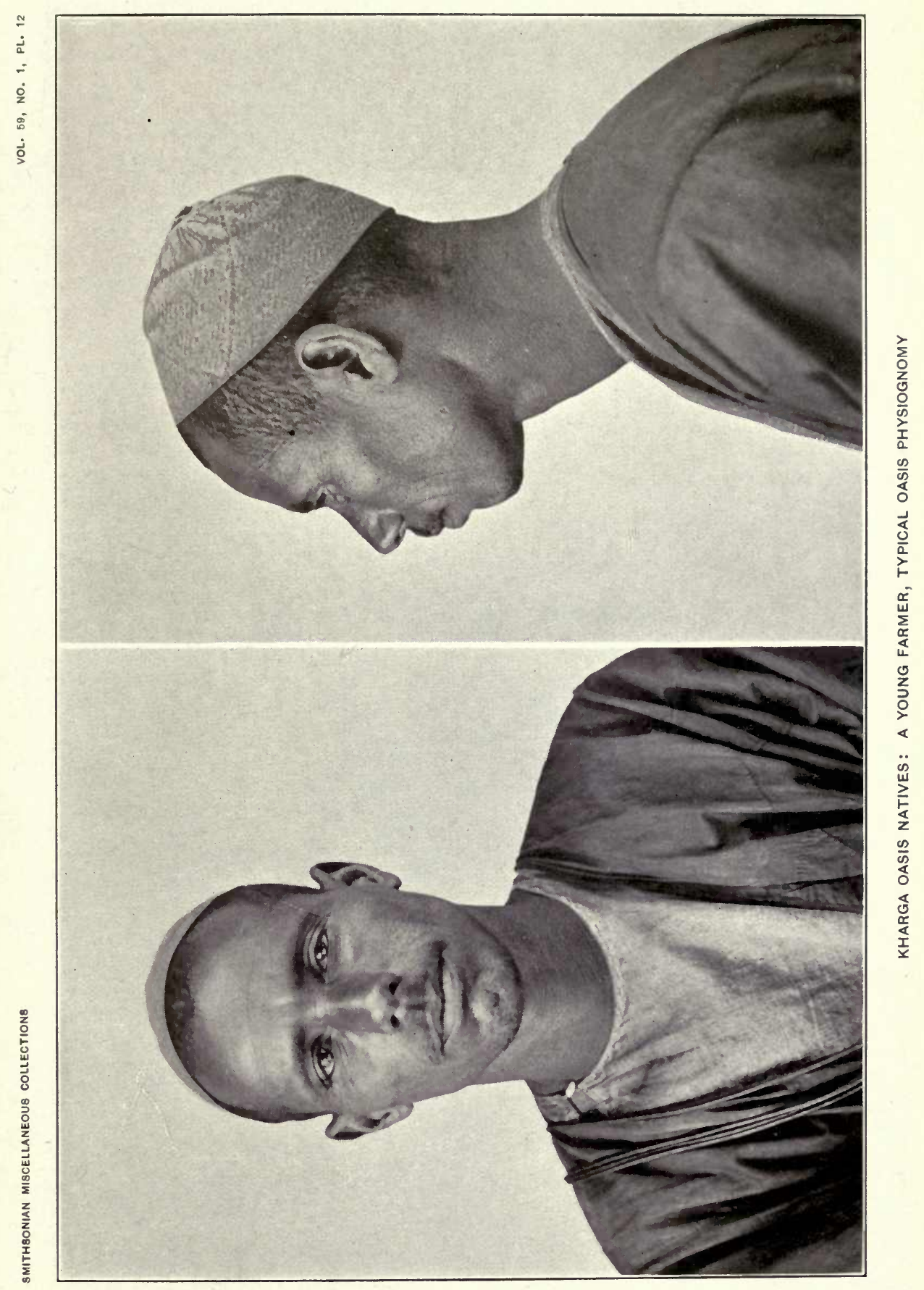




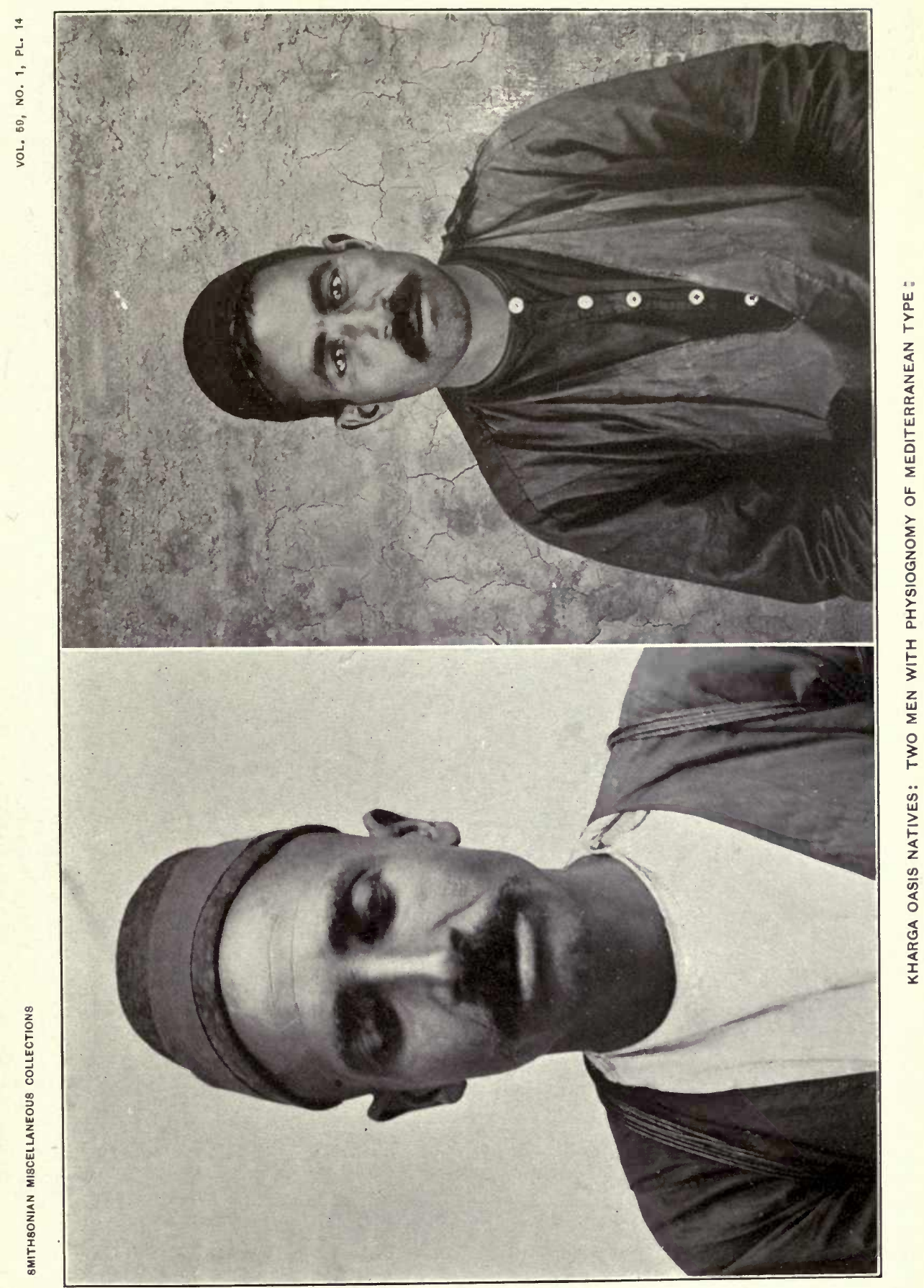




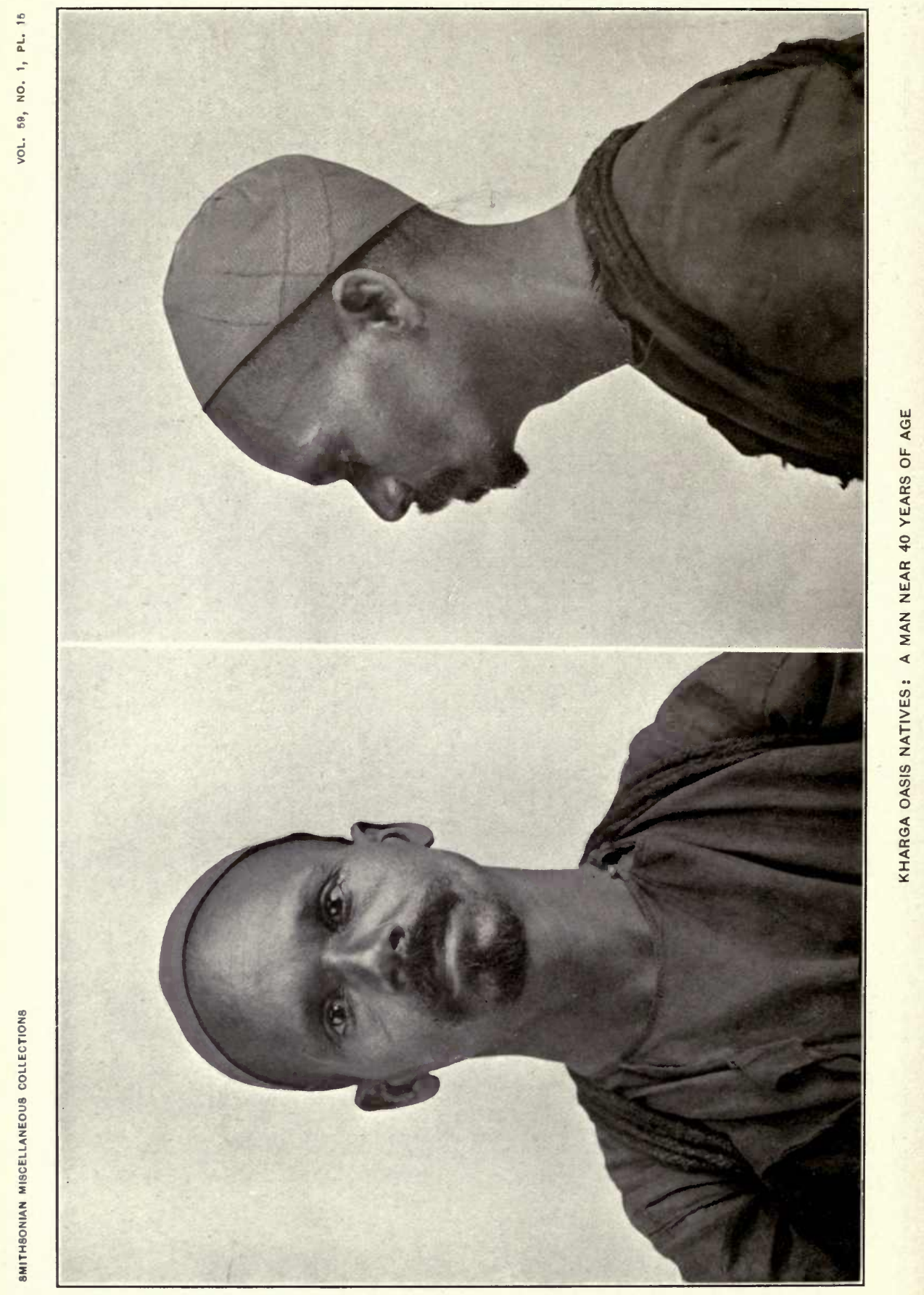




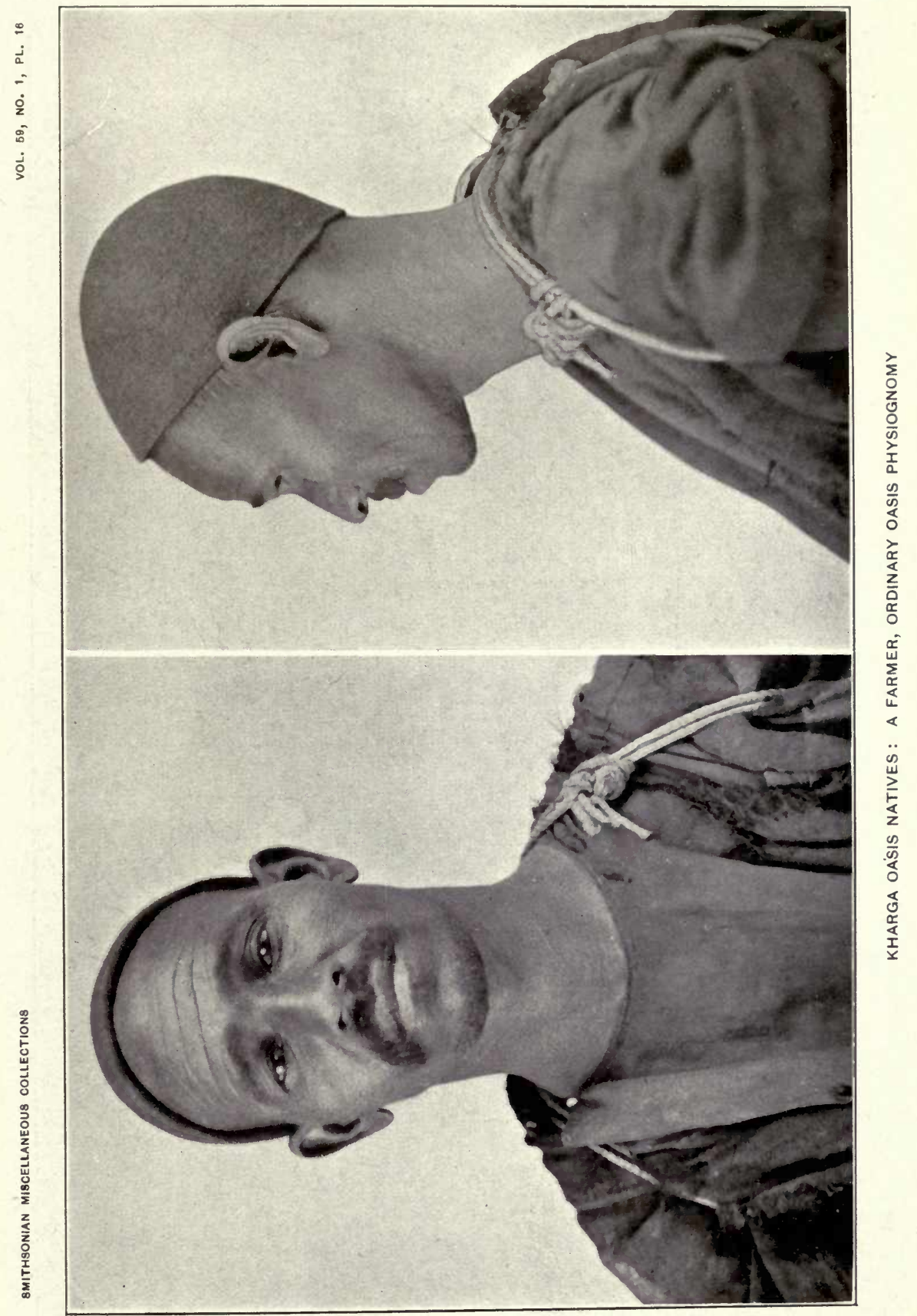




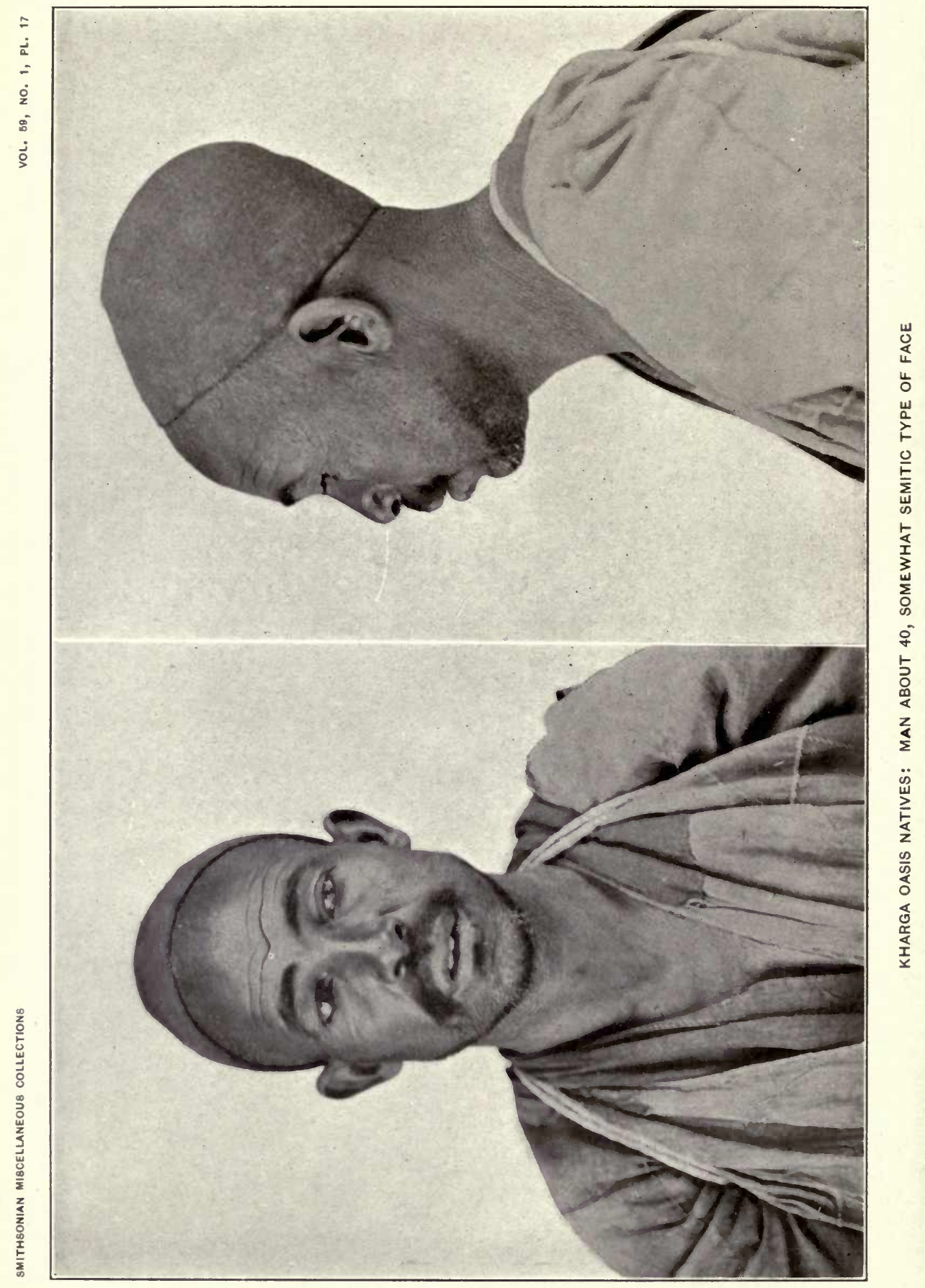




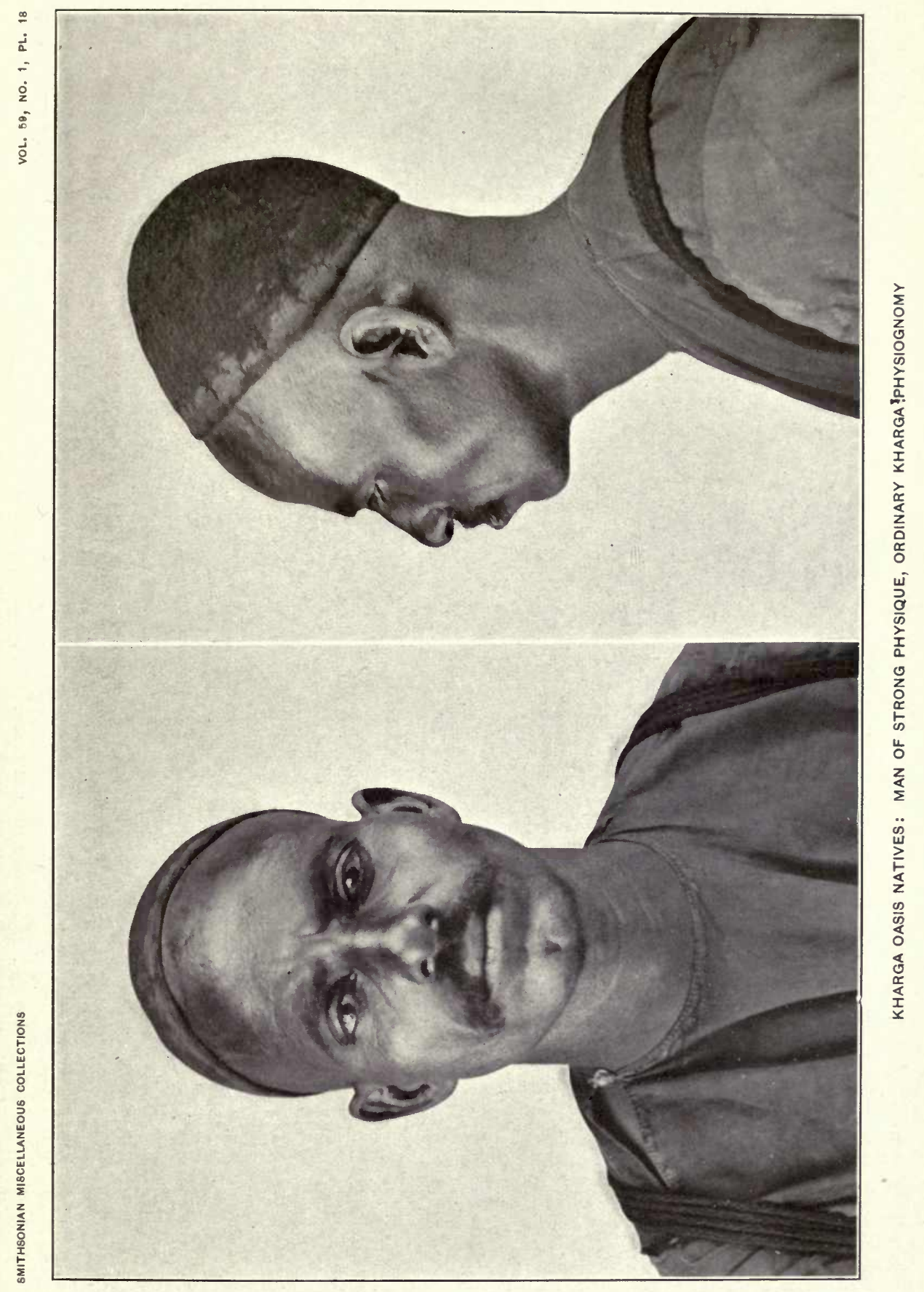




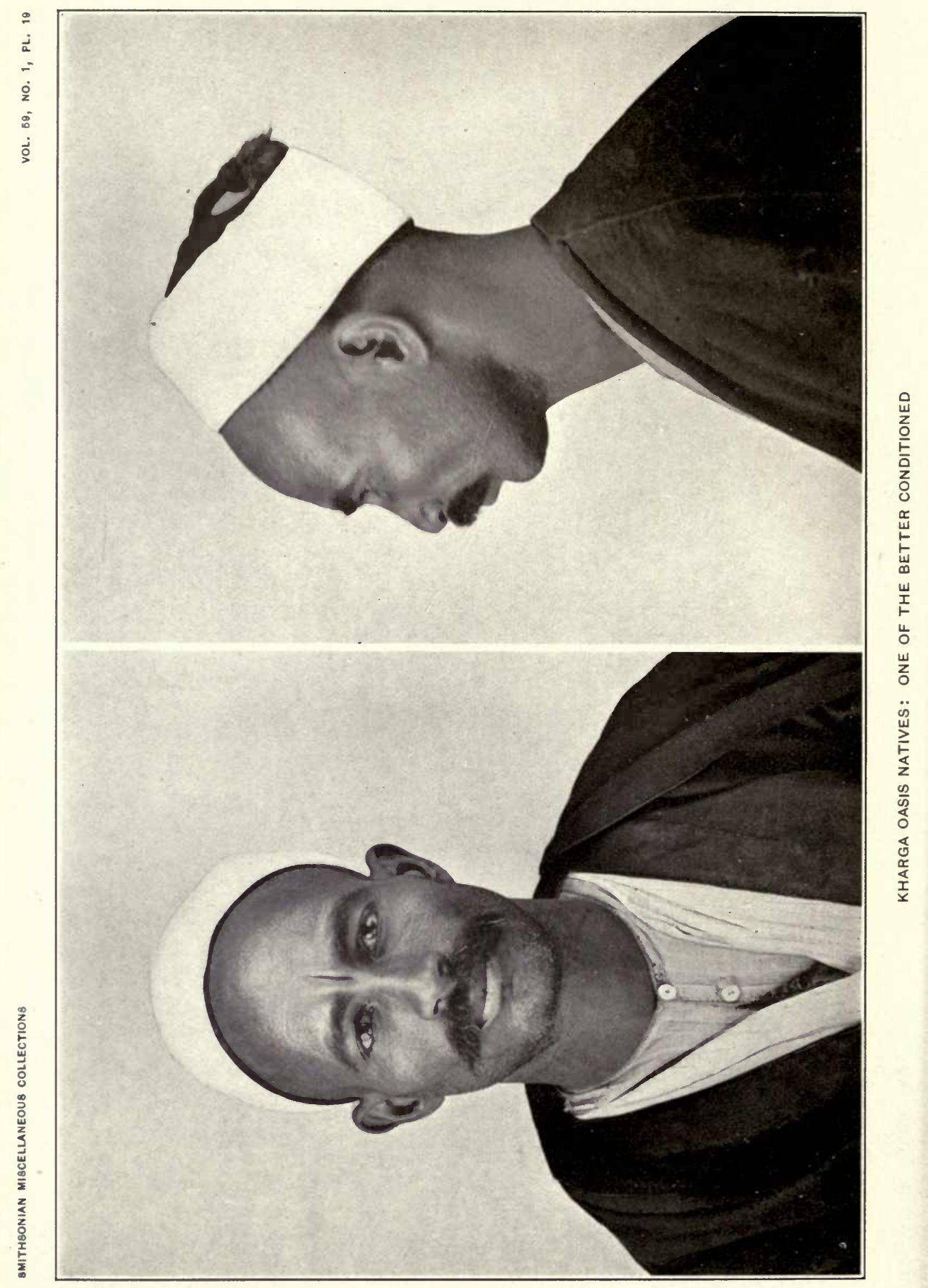




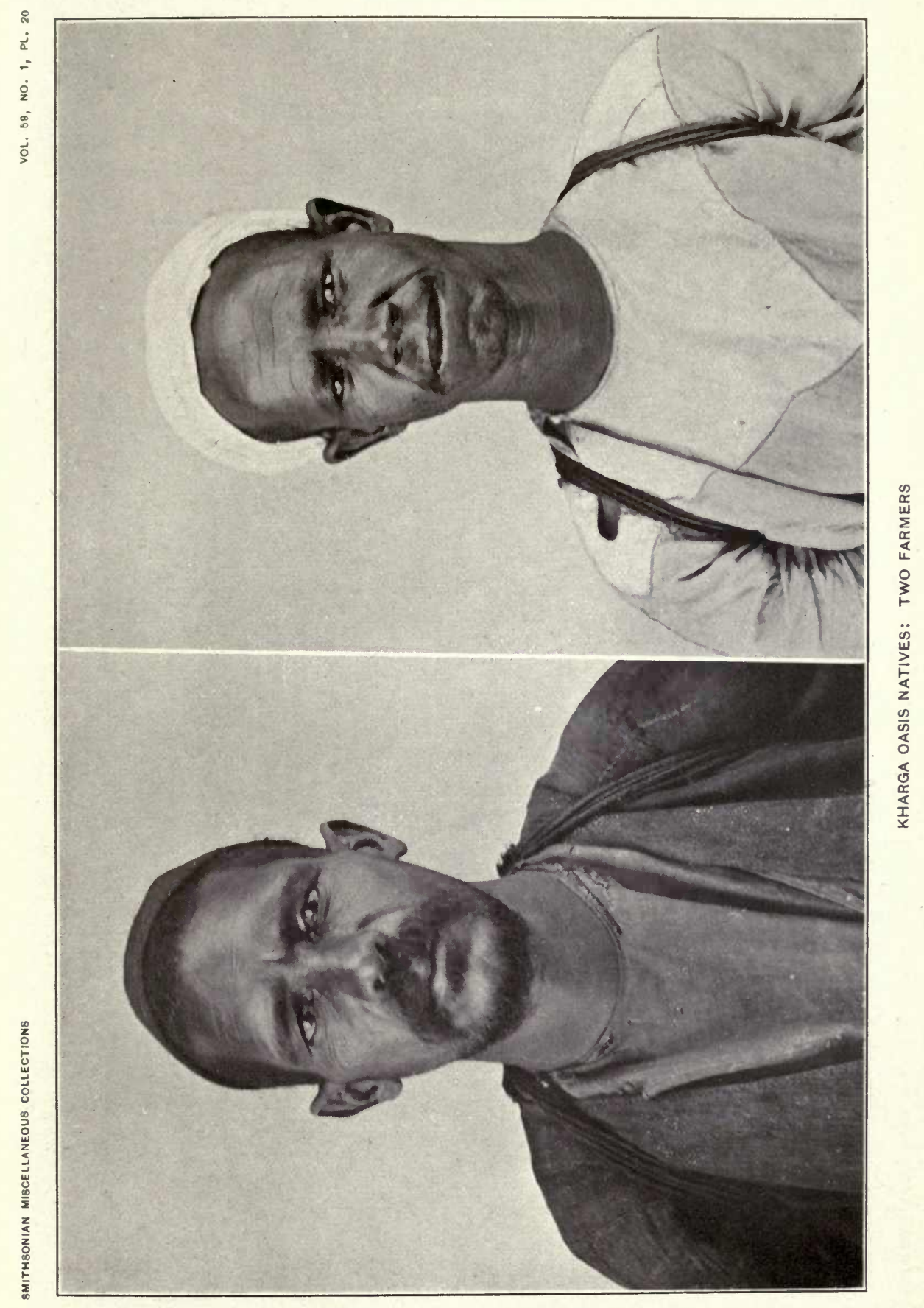




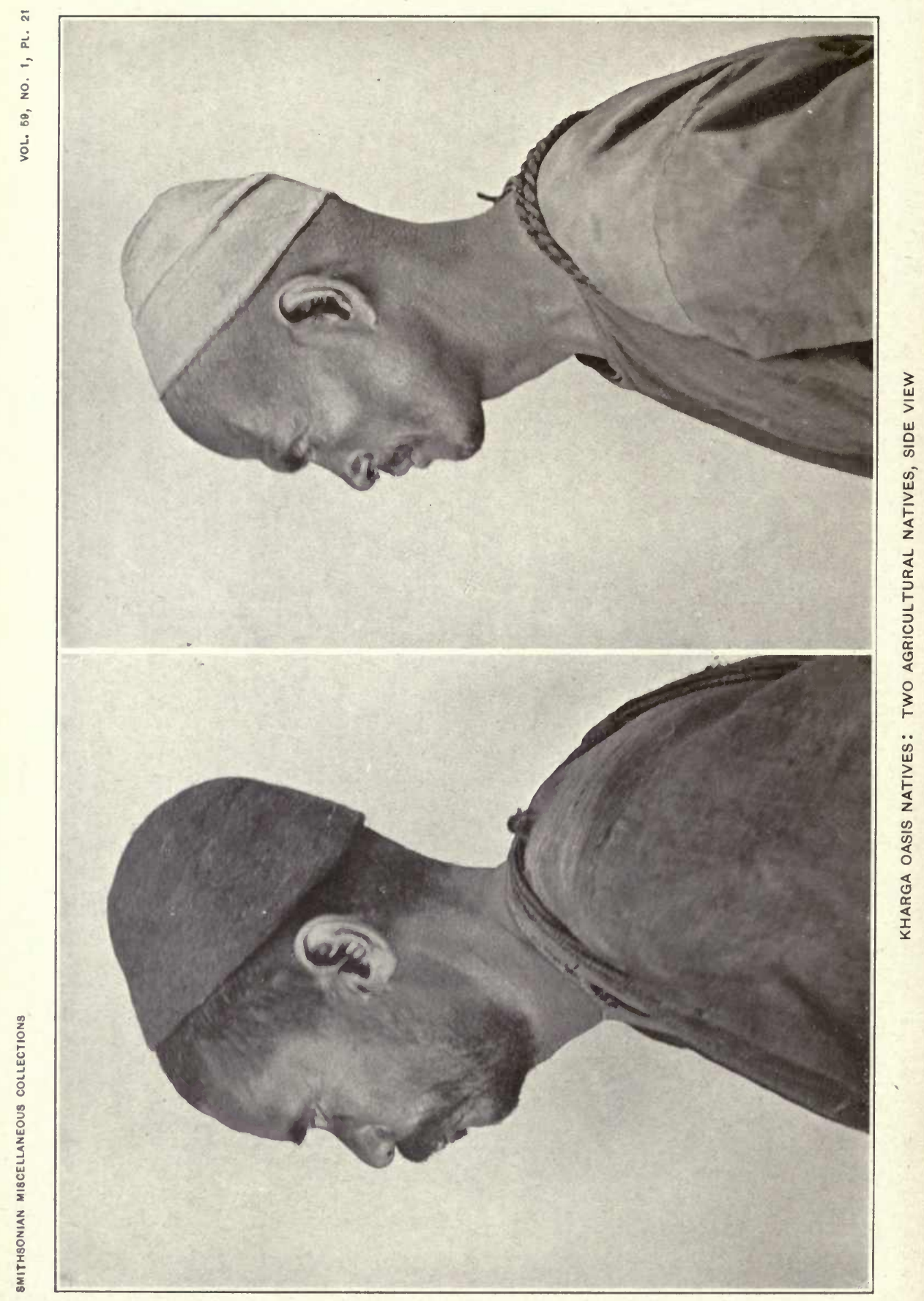




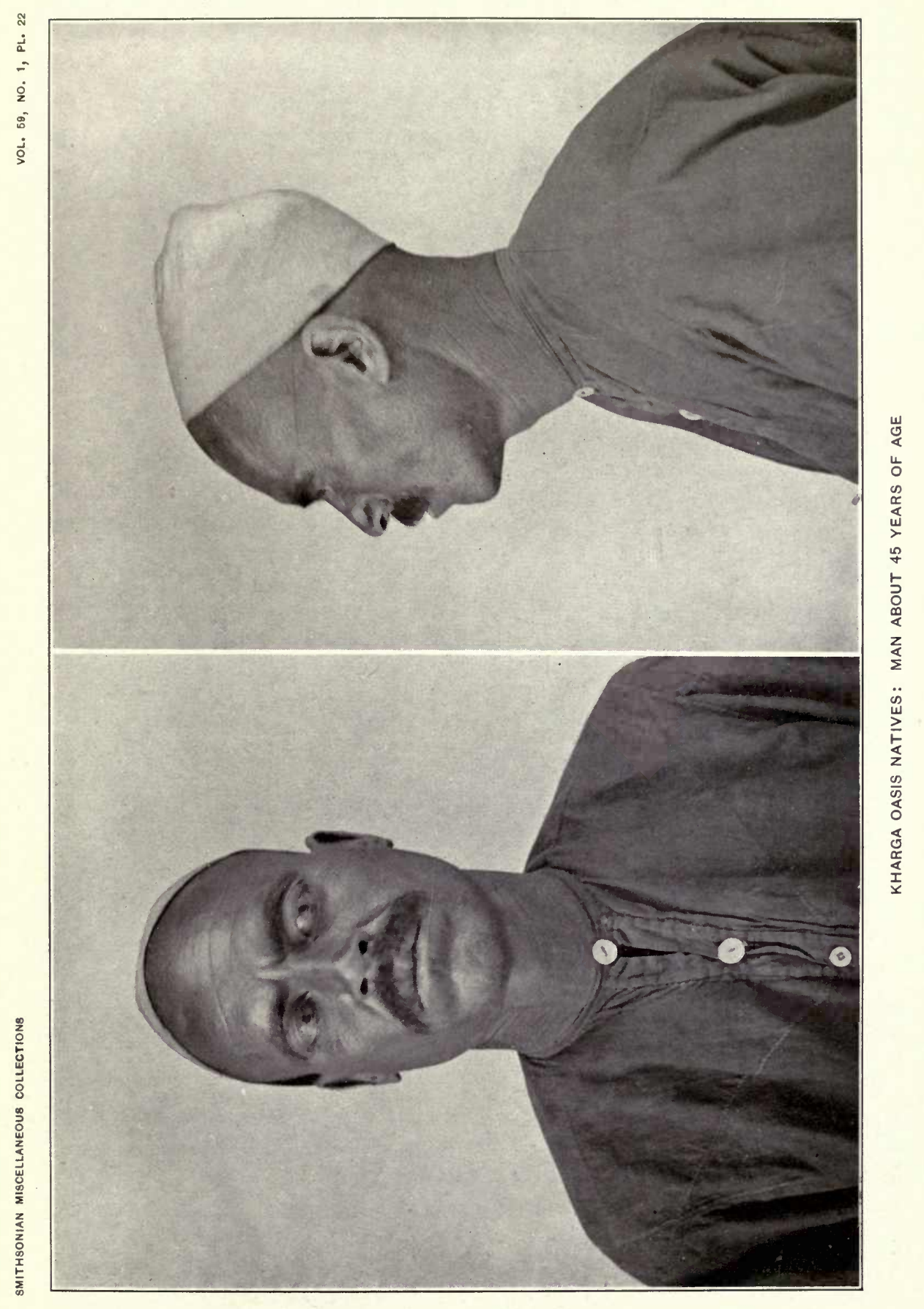




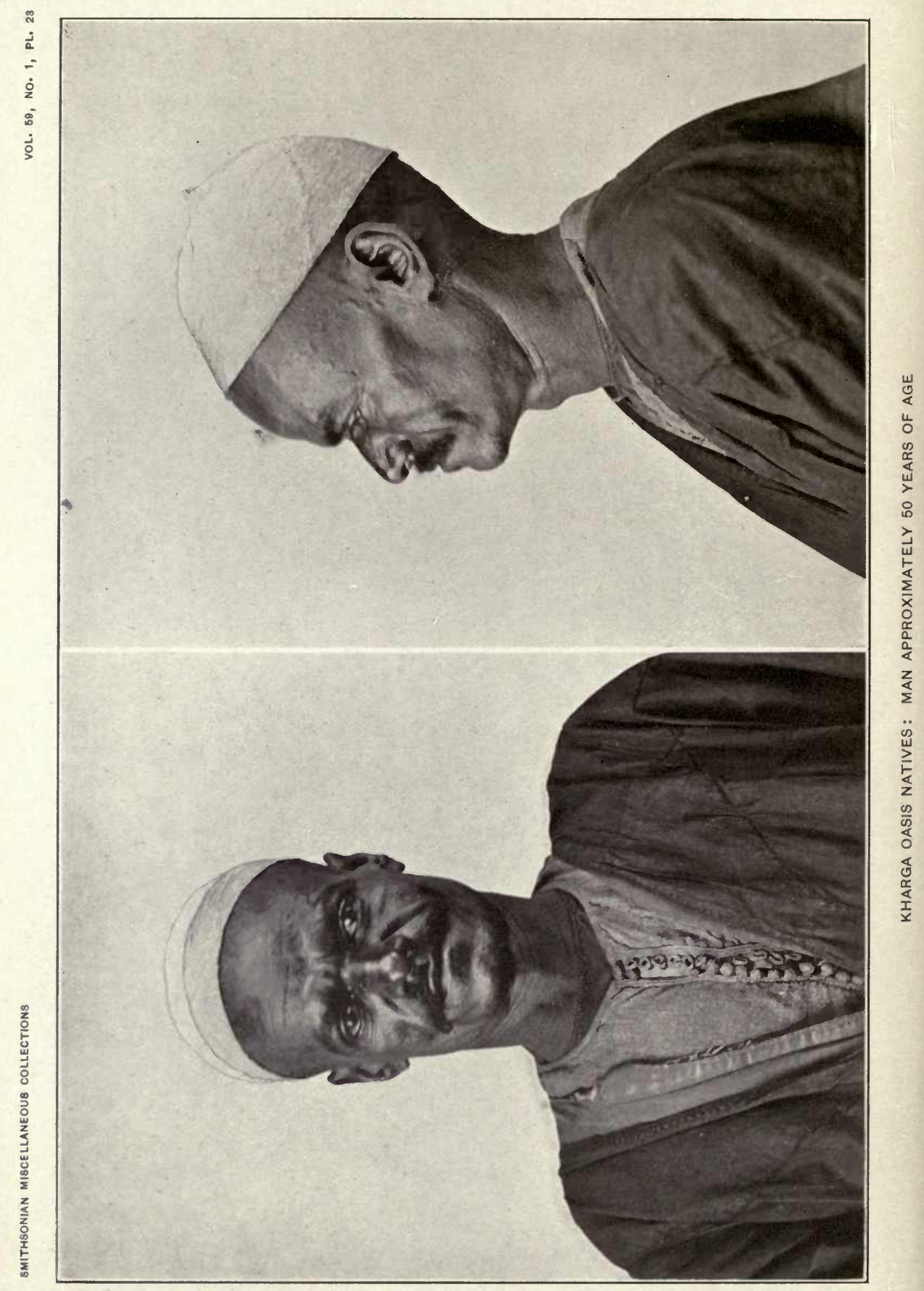




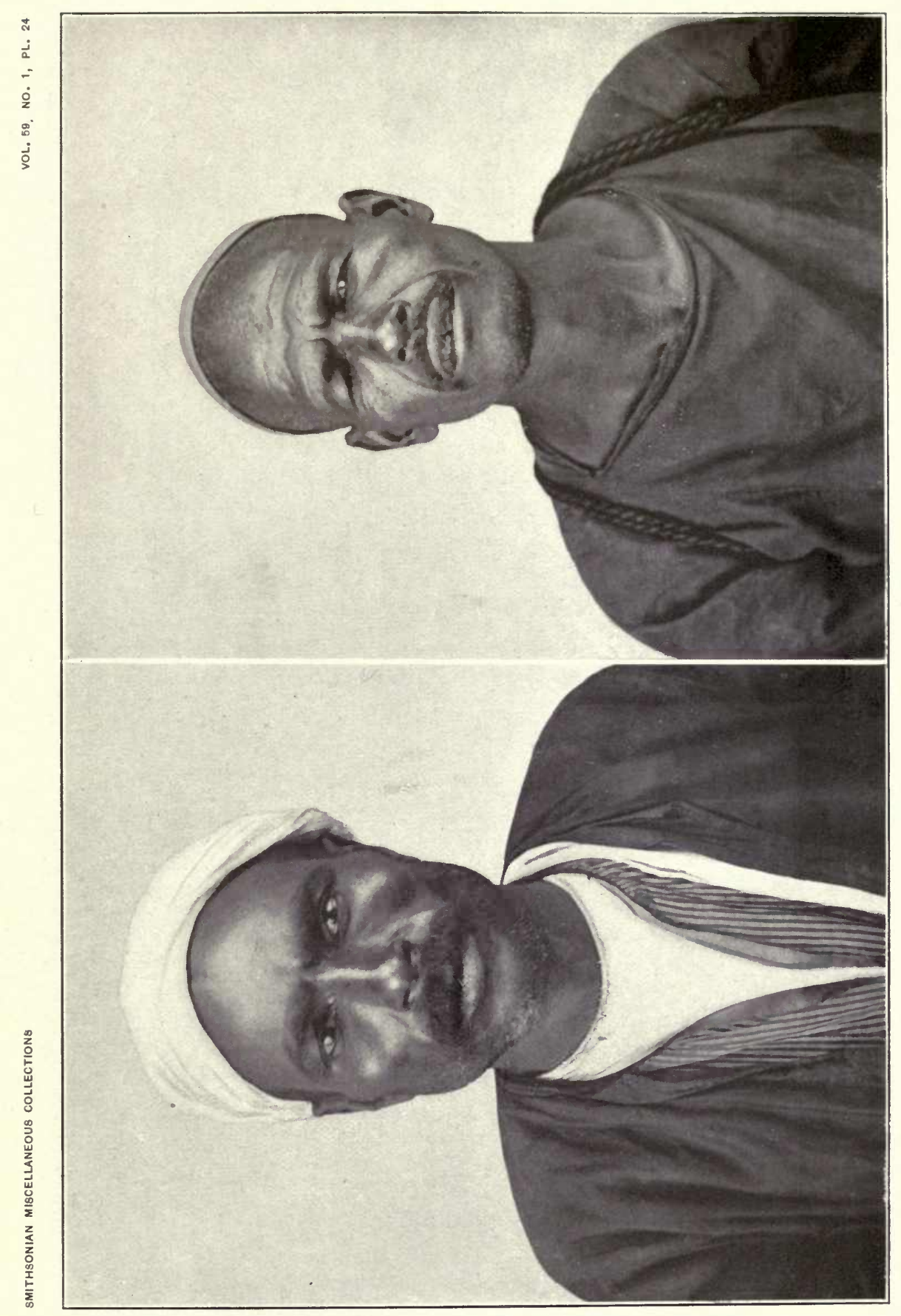

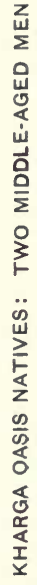




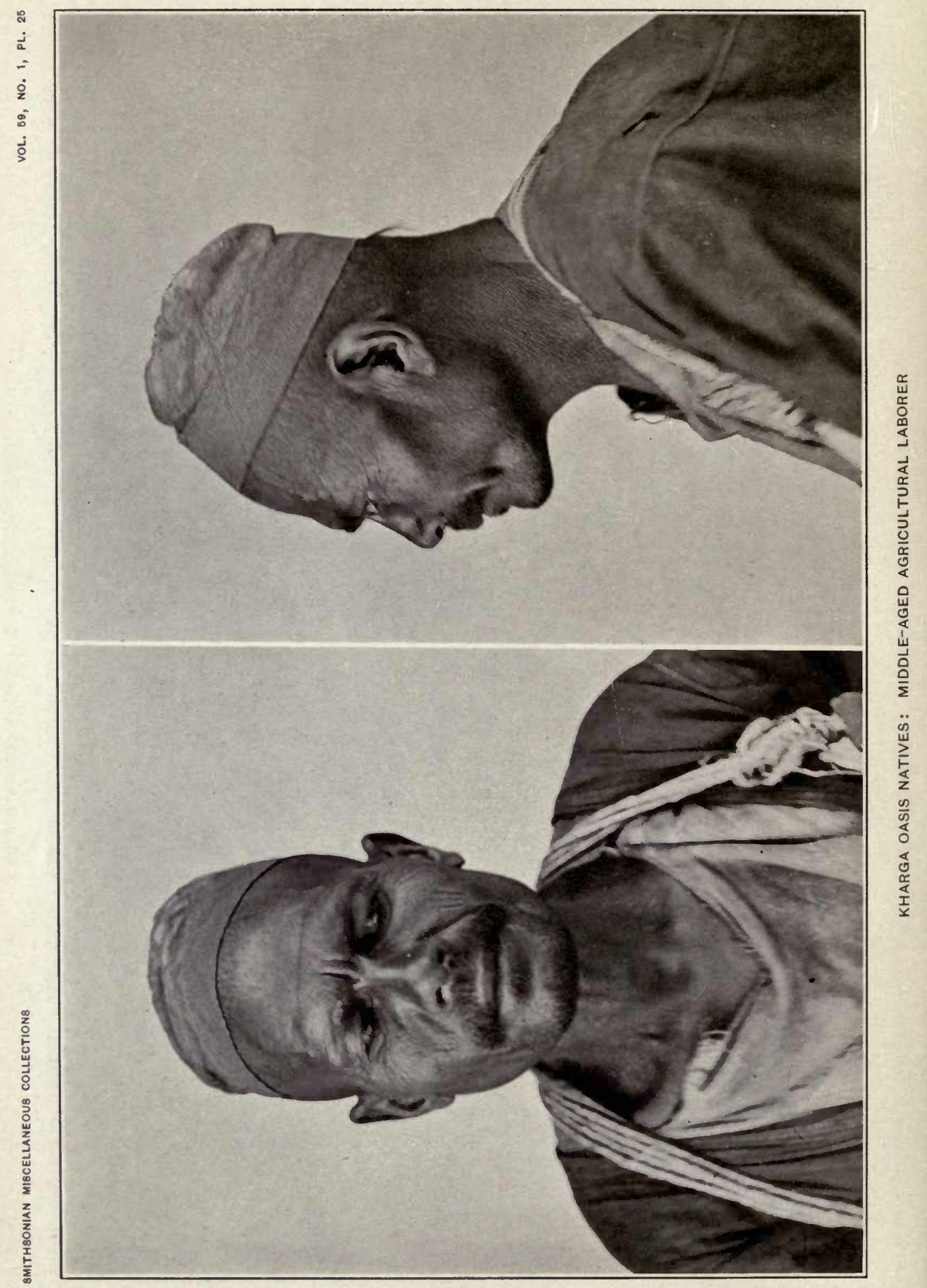




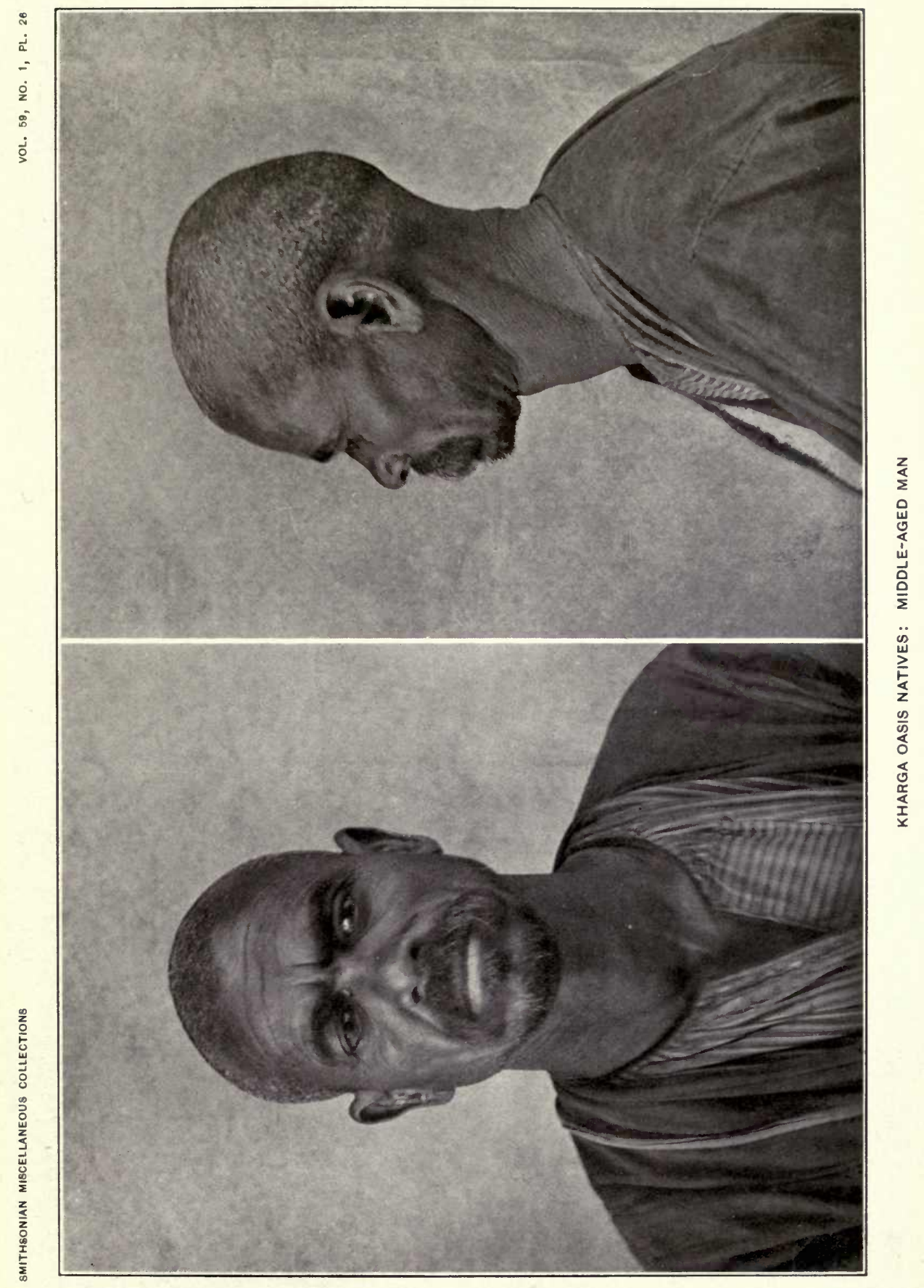




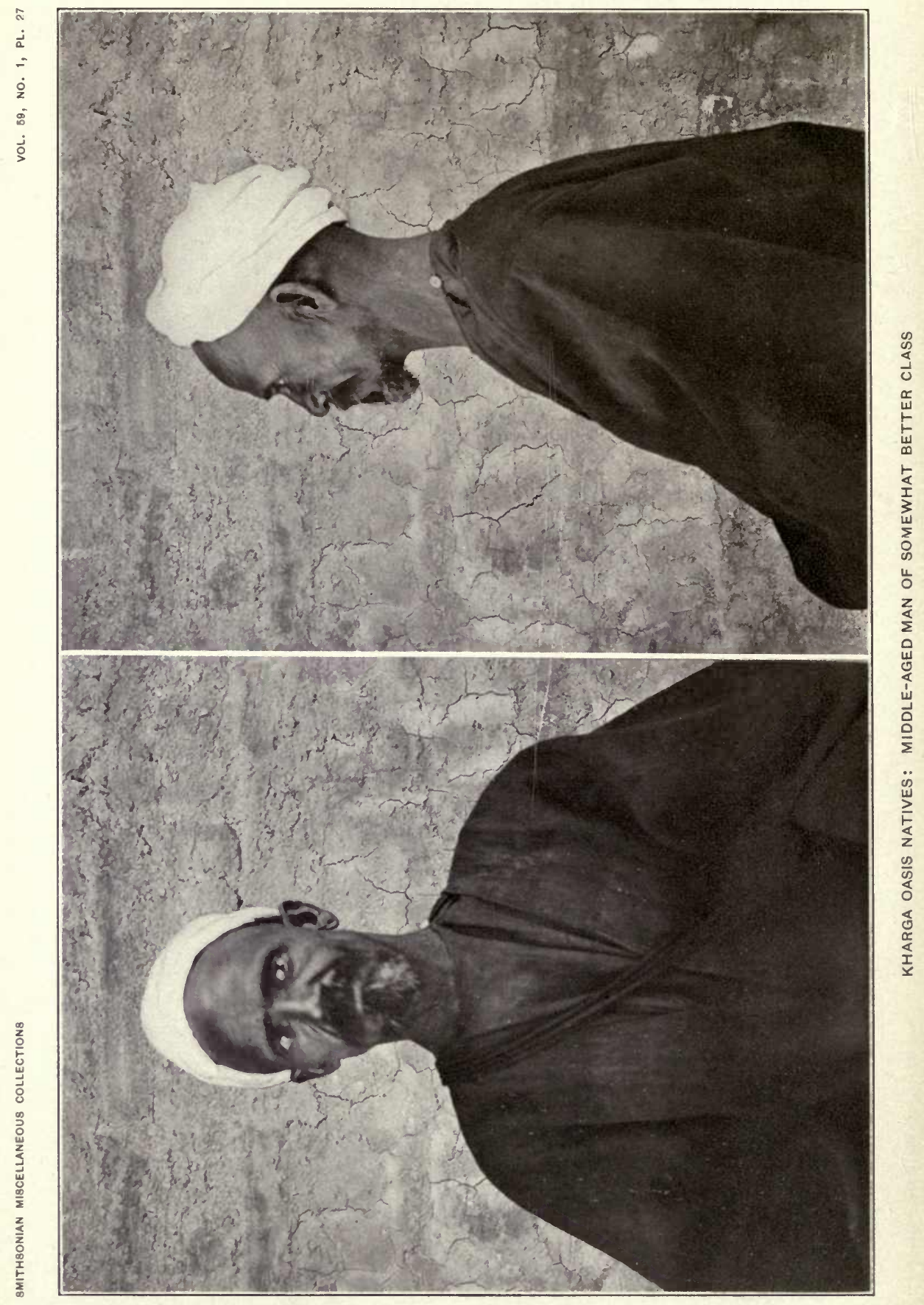




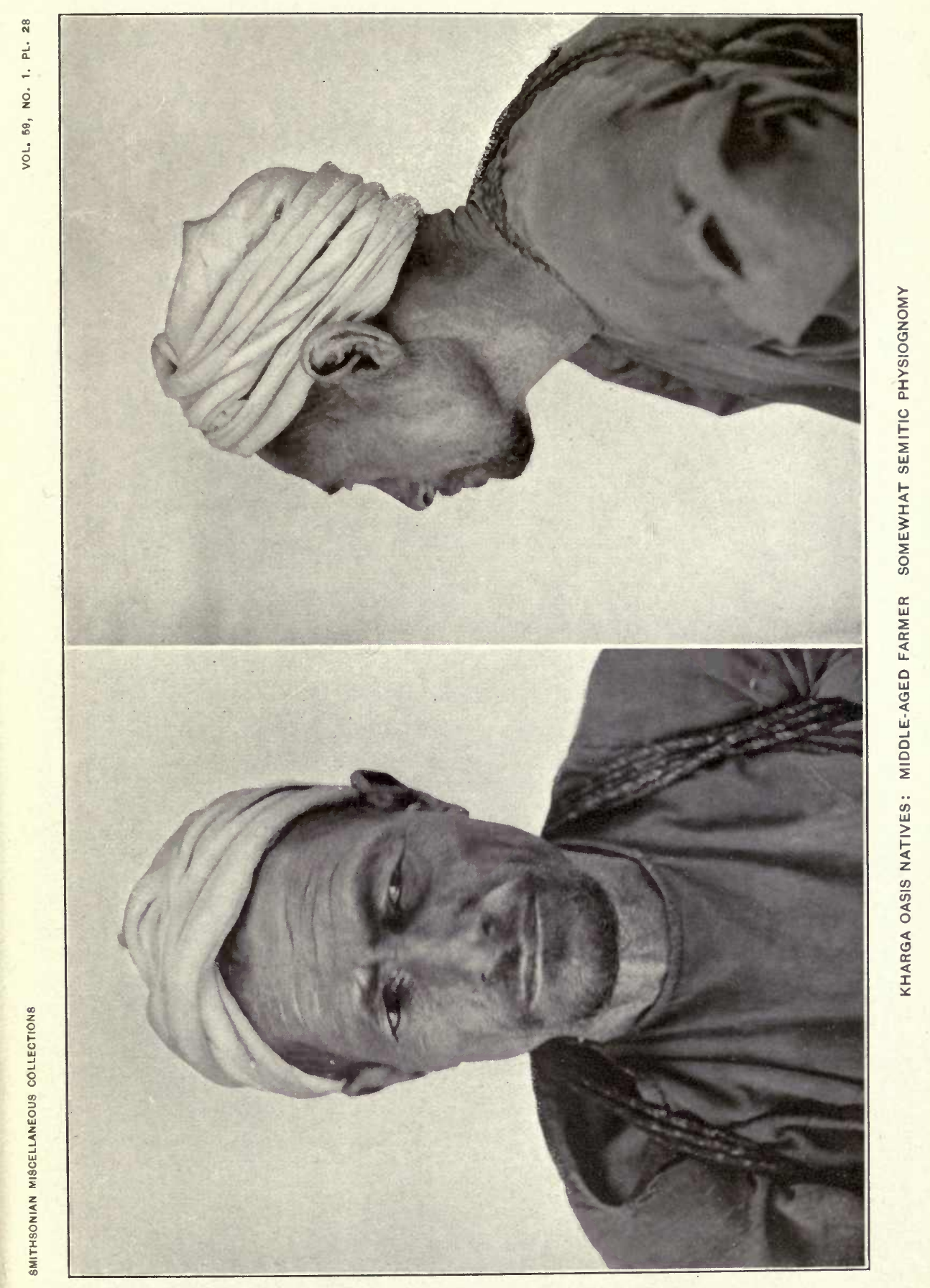




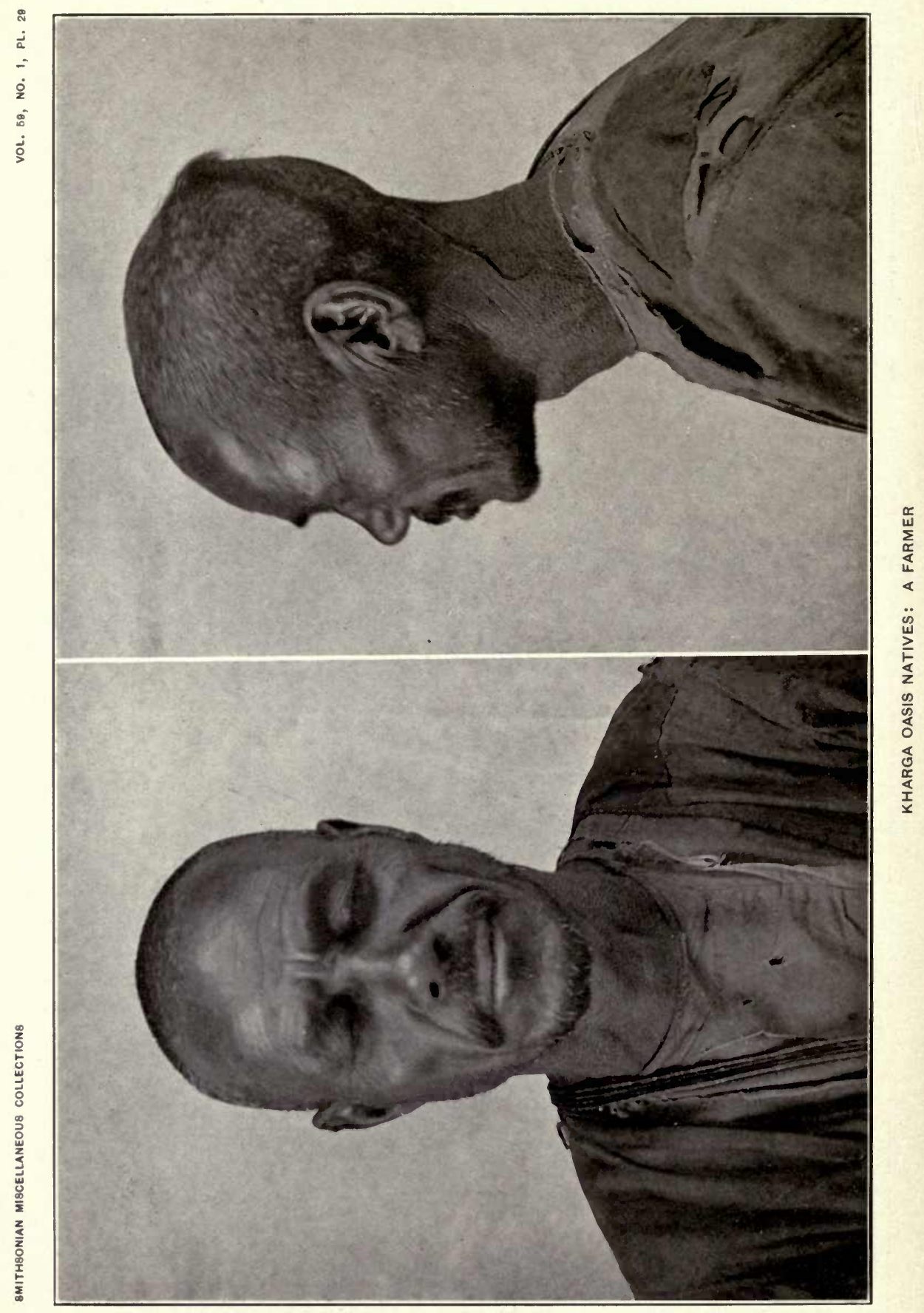




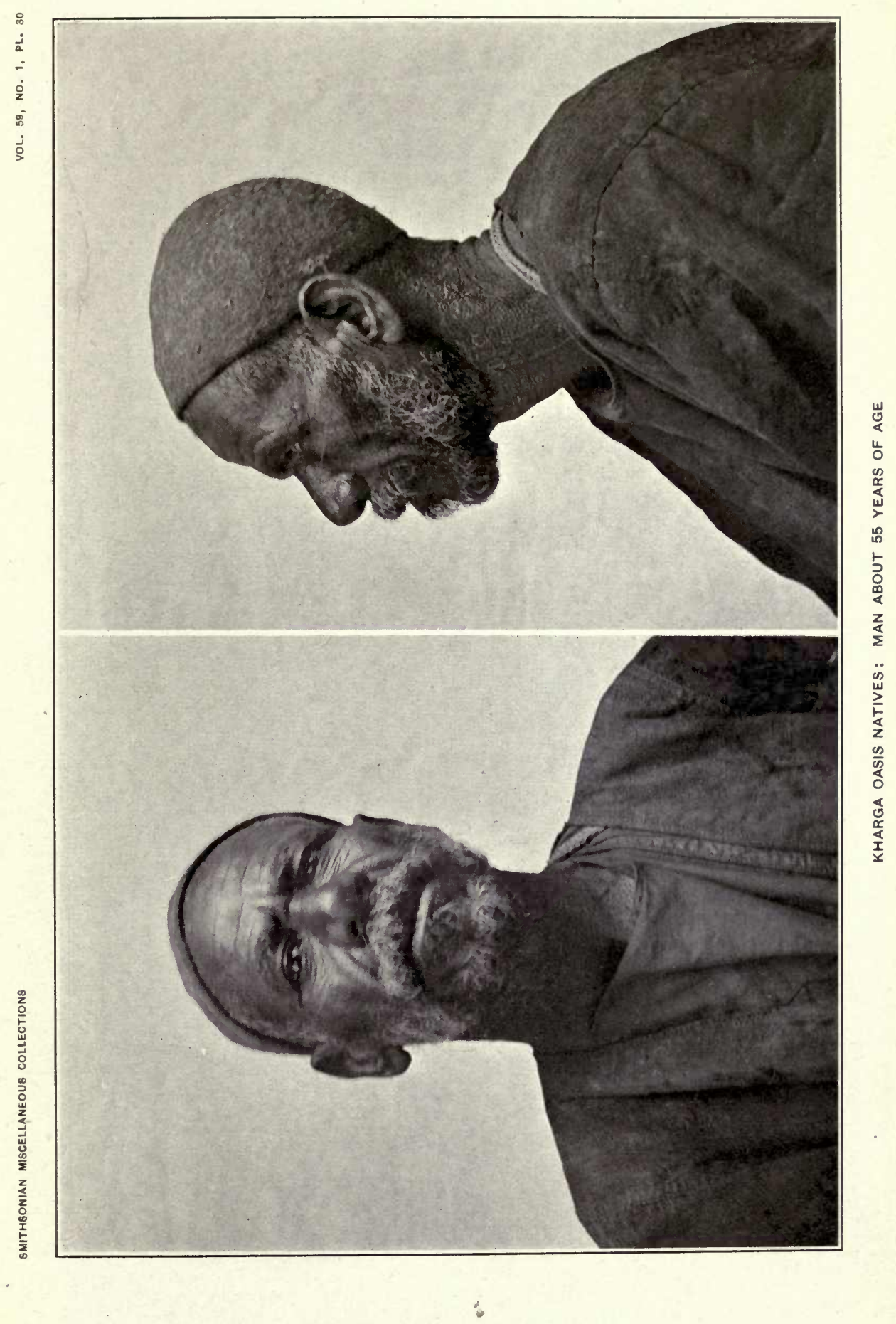




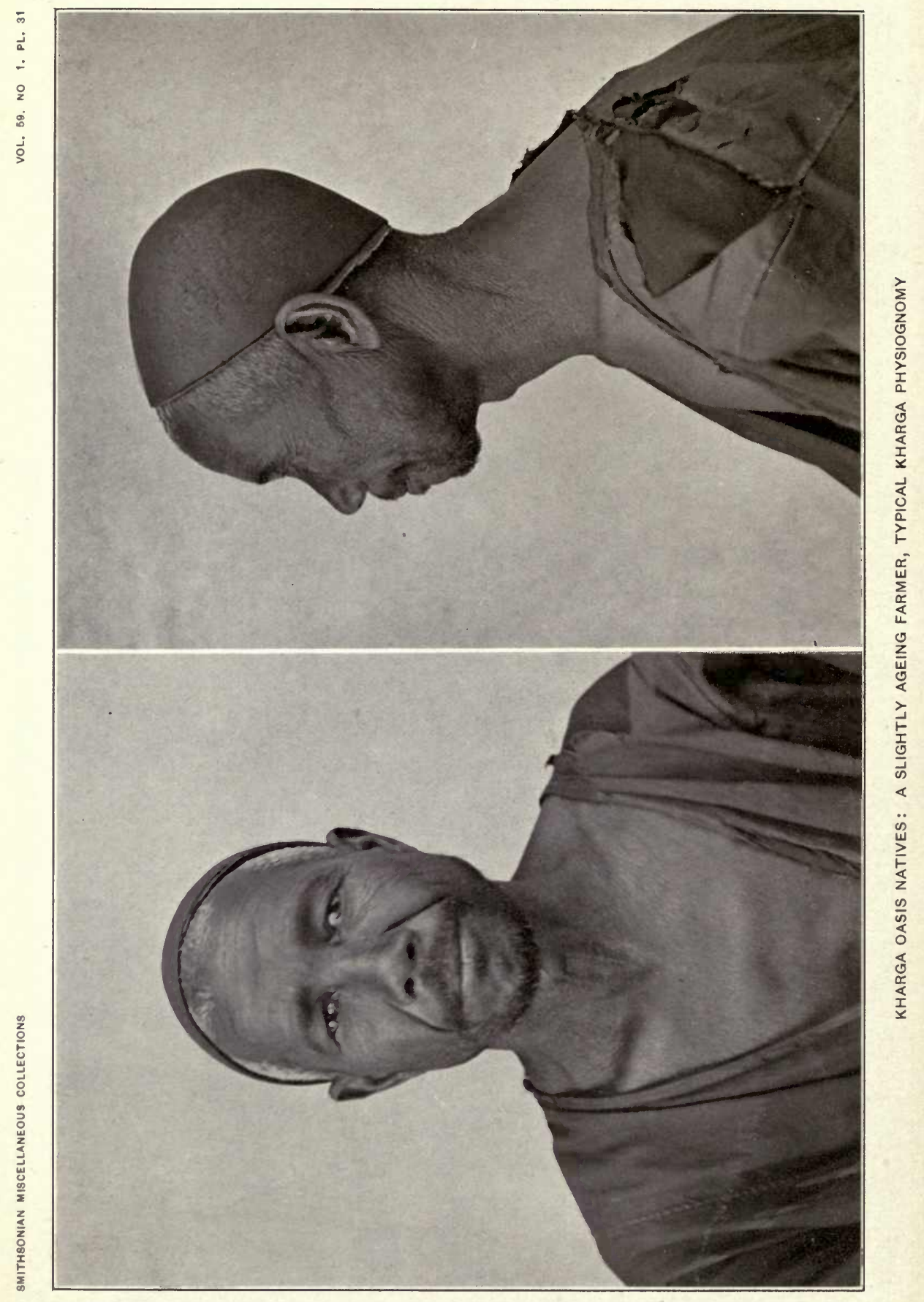




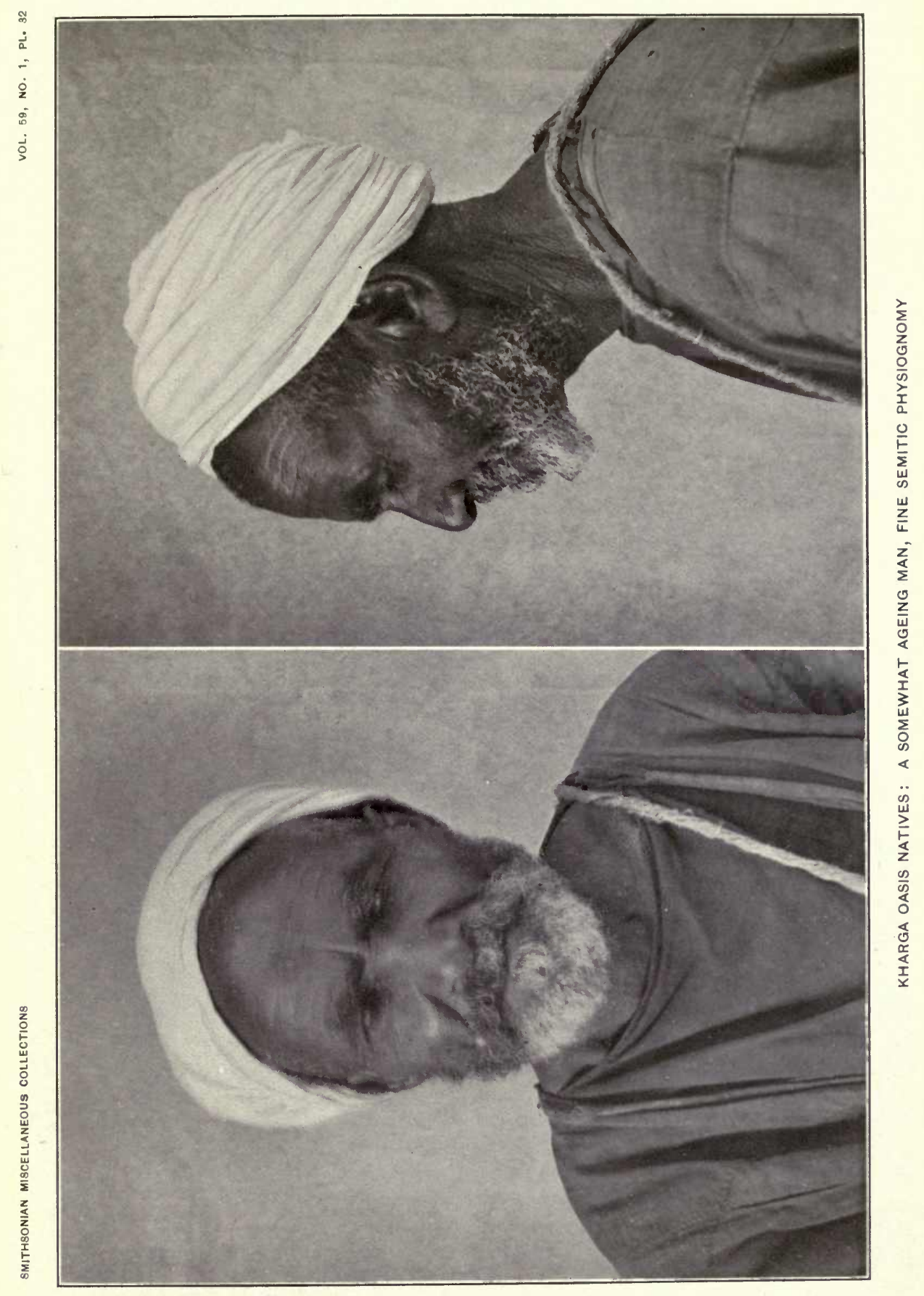




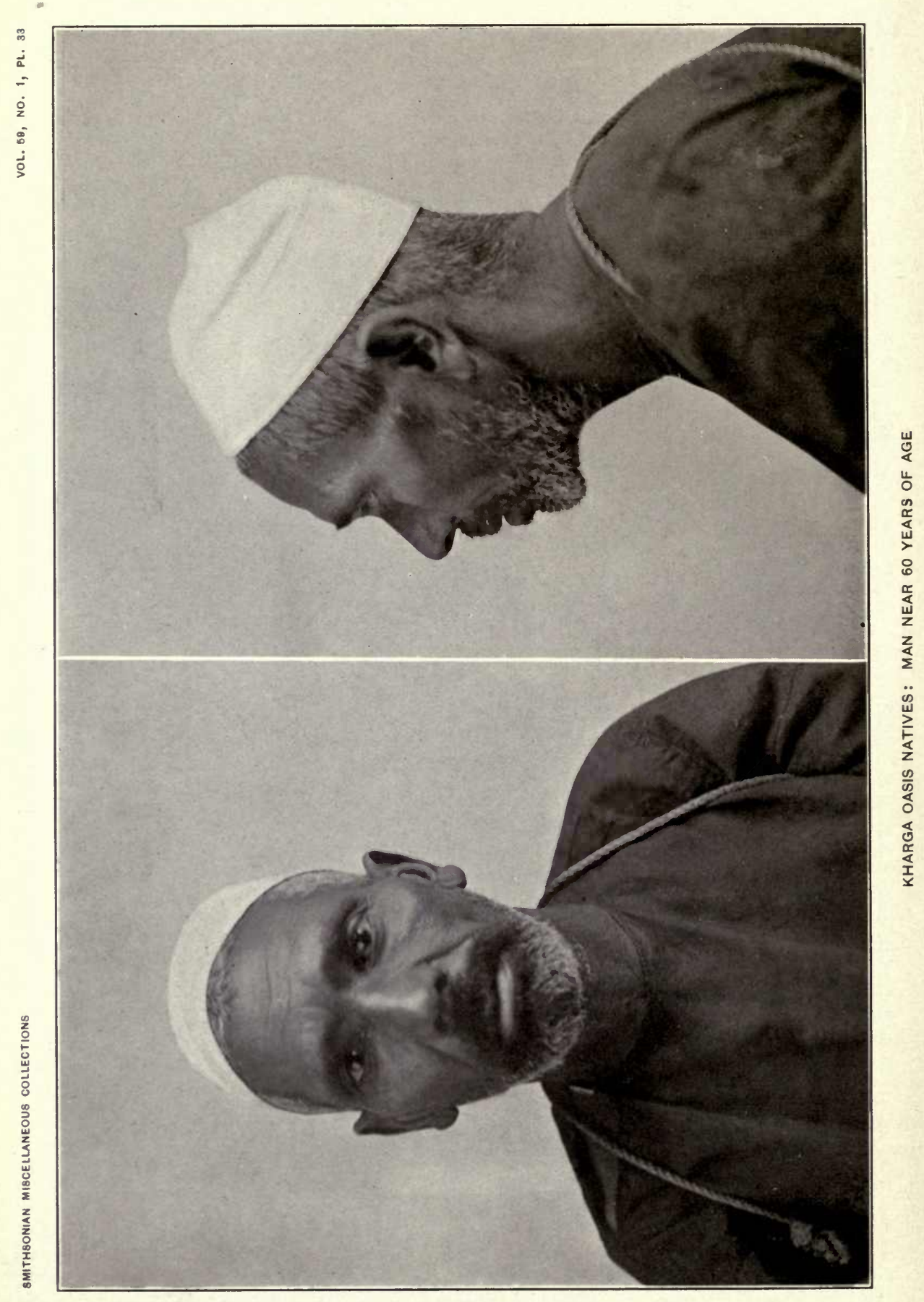




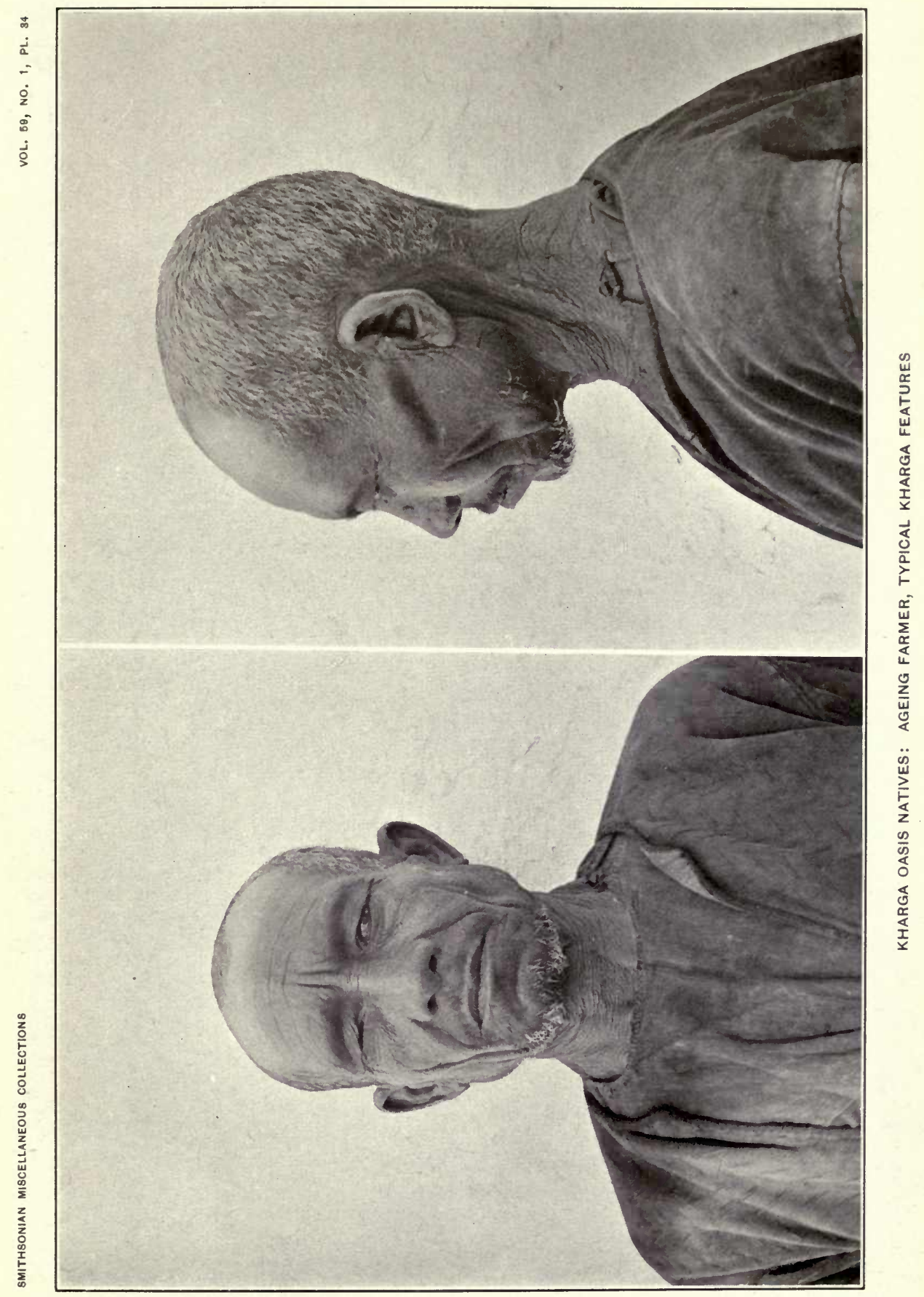




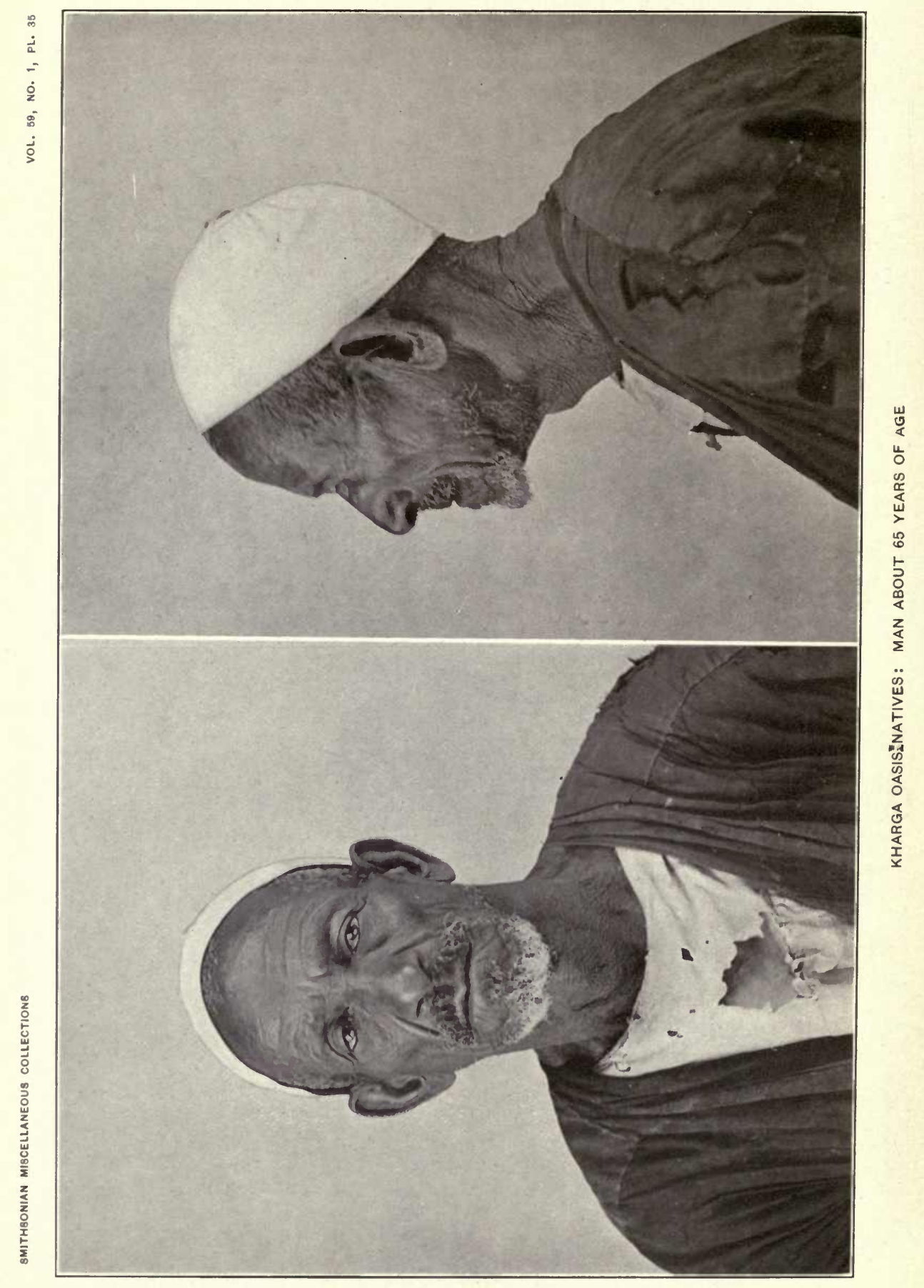




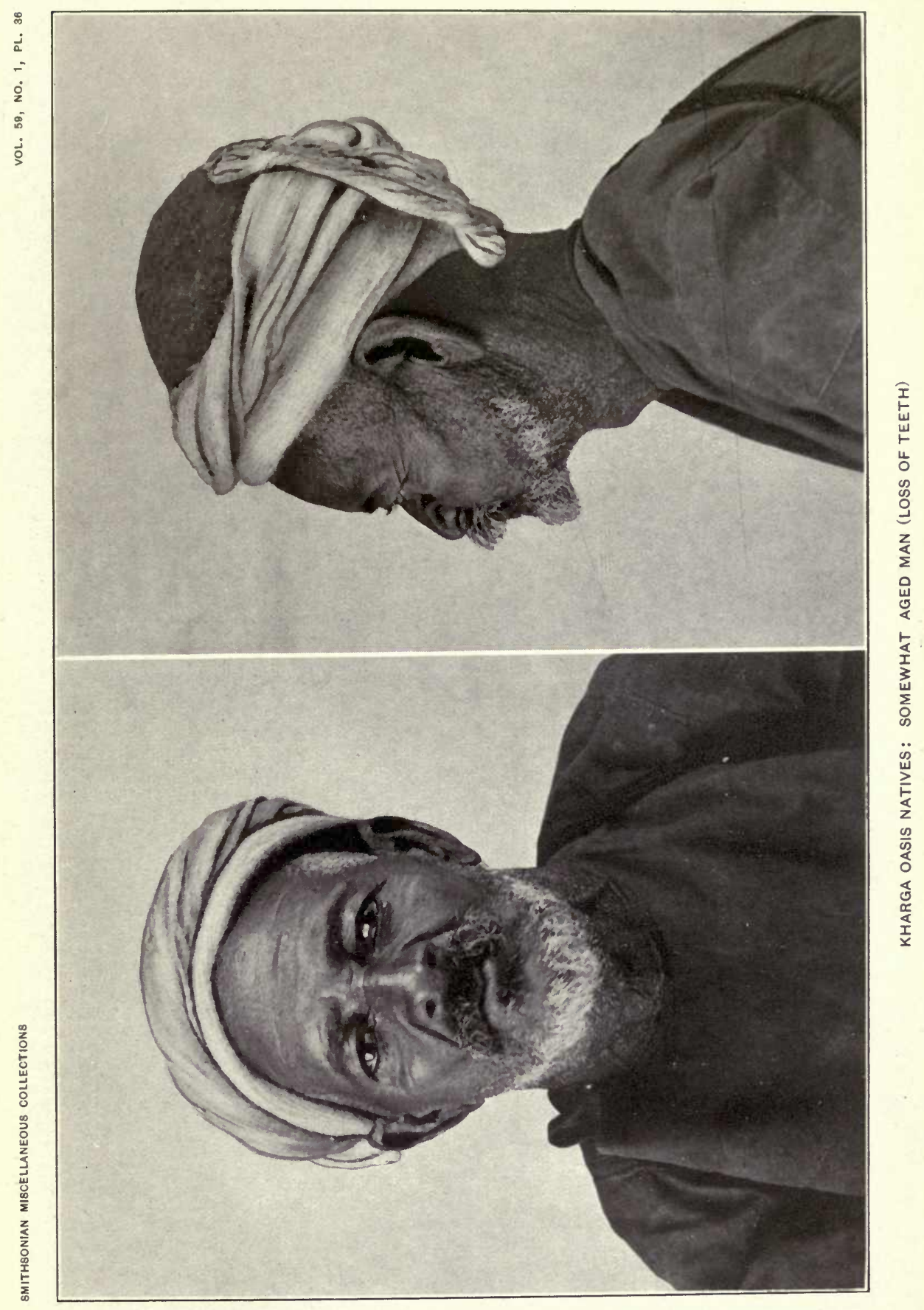




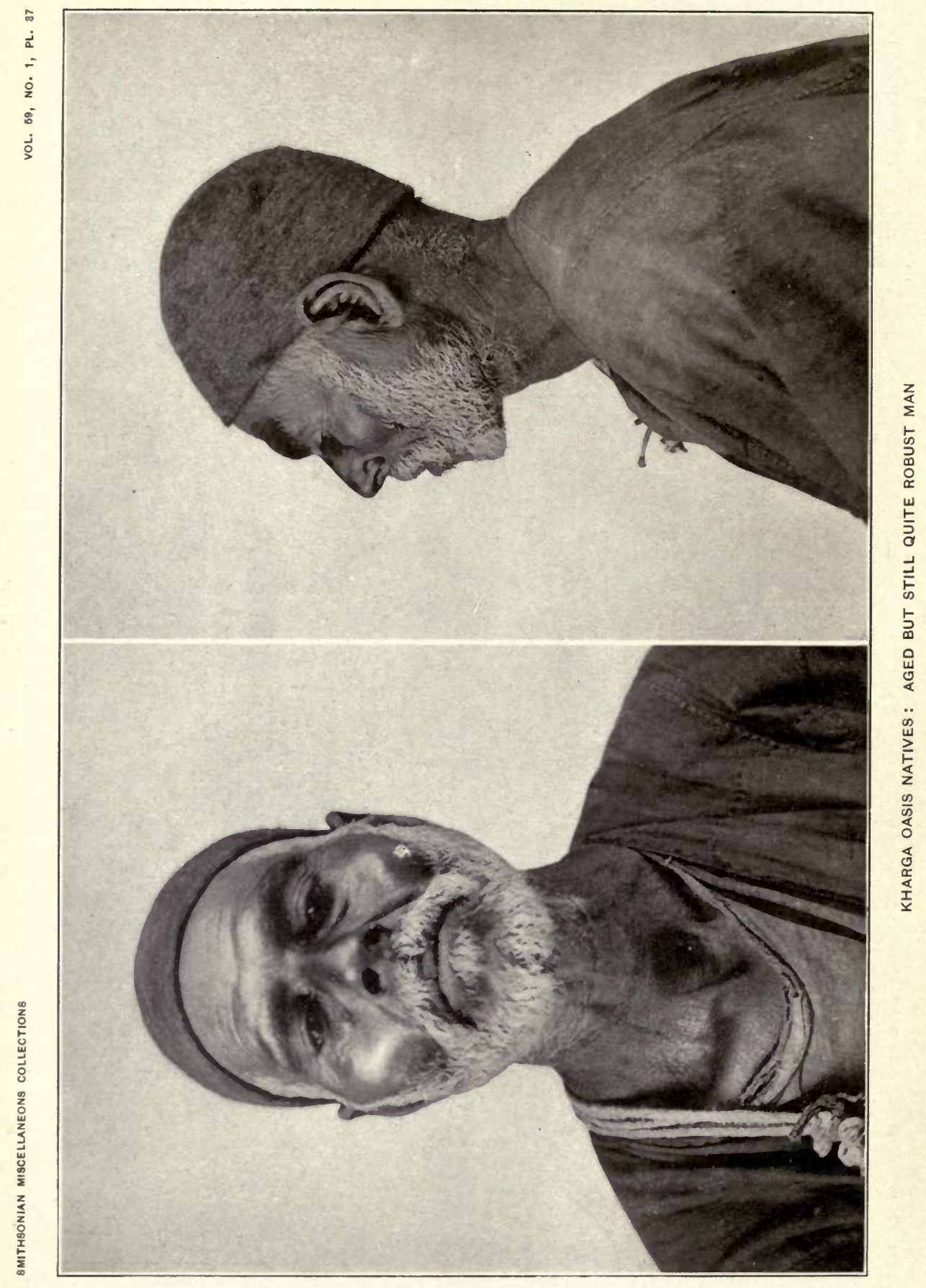




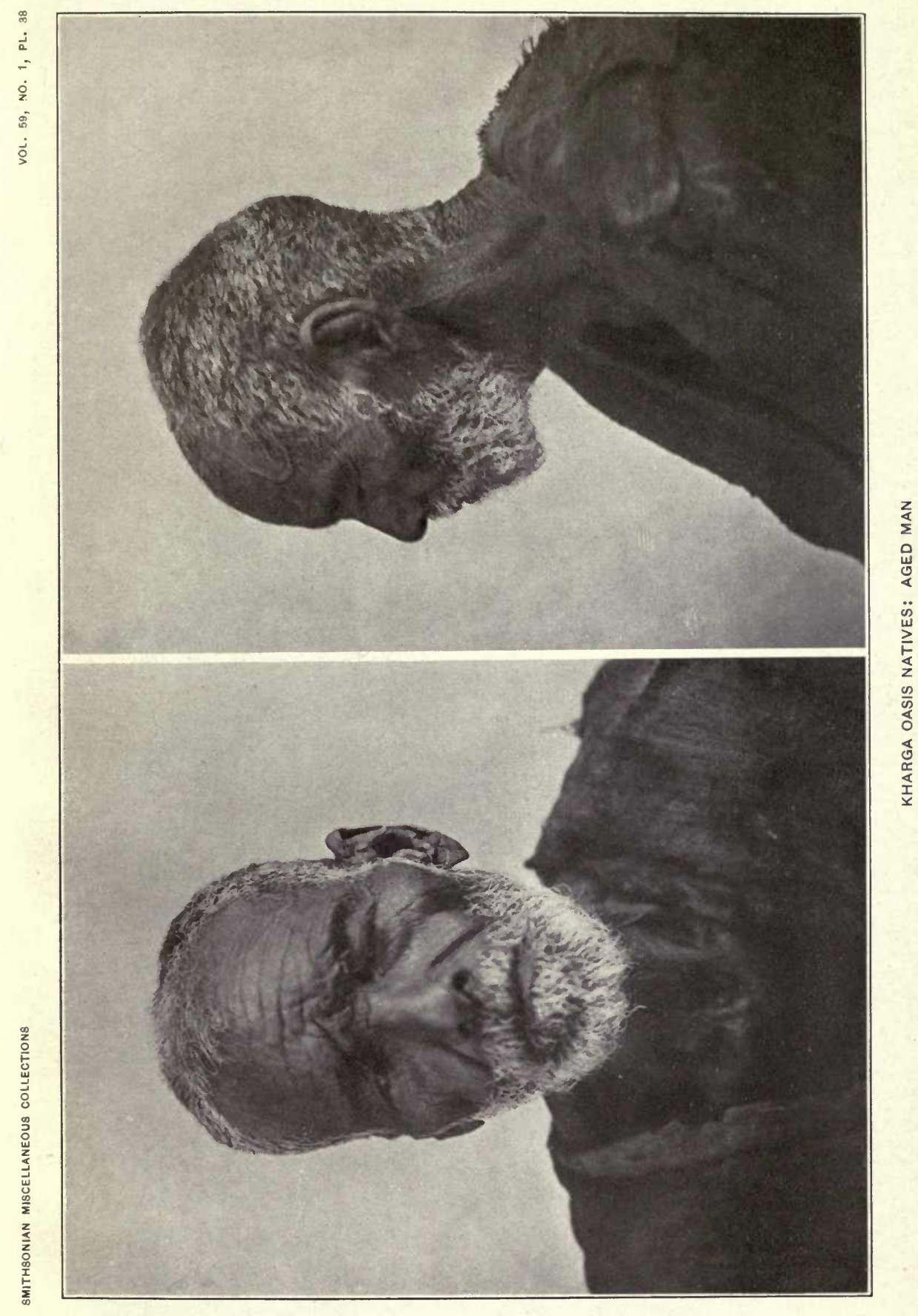








\section{DAY USE}

RETURN TO DESK FROM WHICH BORROWED

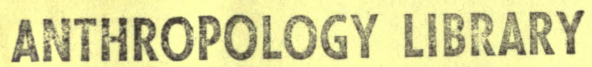

This publication is due on the LAST DATE and HOUR stamped below.

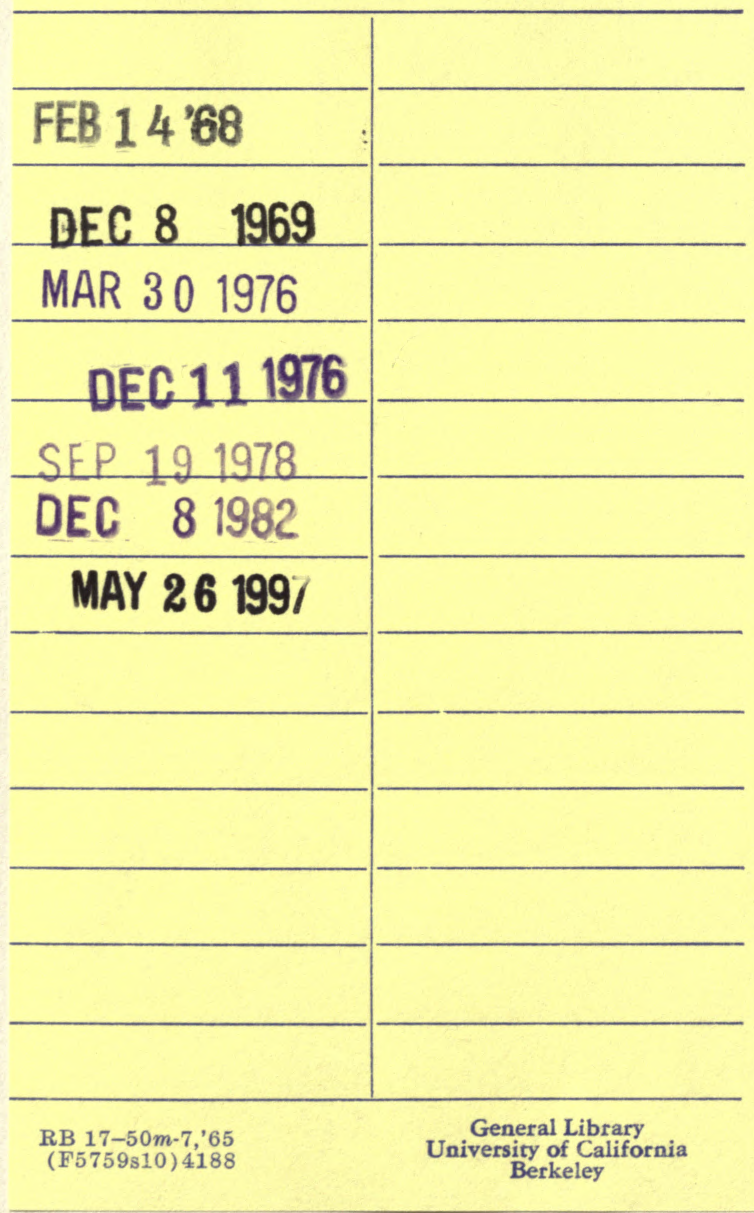


U.C. BERKELEY LIBRARIES

\section{MILWAUKEE PUBLIC MUSEUM} FROM S. A. BARRETT 
